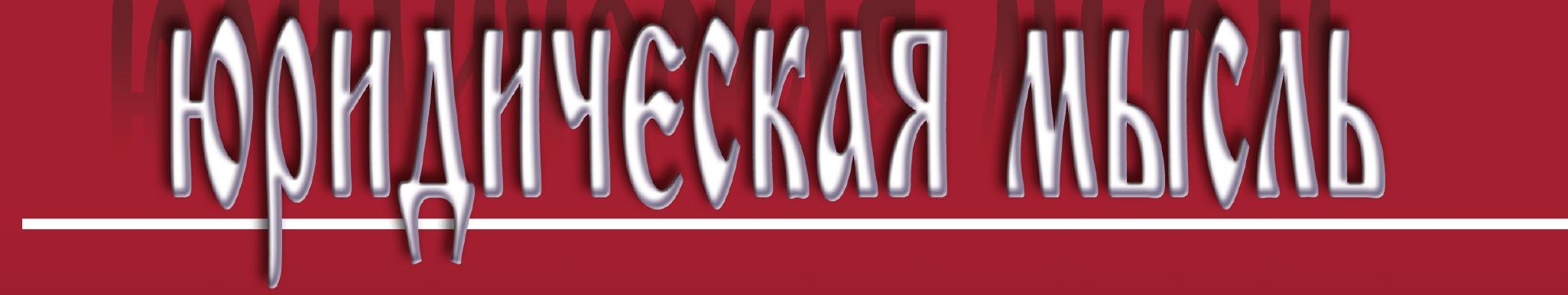

№ 4,2021

ISSN: $2071-4920$ (Print) ISSN: 2712-7818 (Online) 


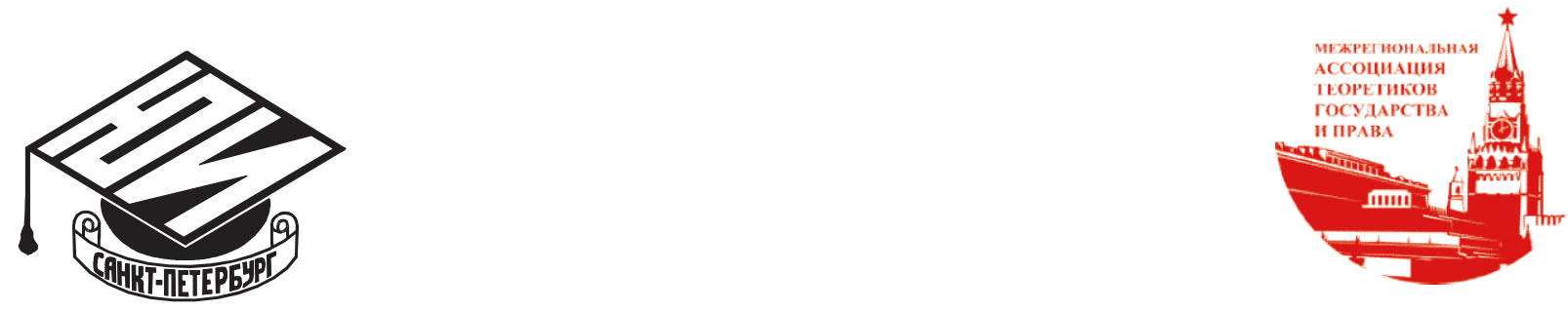

\section{Юридическая}

МЫСАЬ

20214 (124)
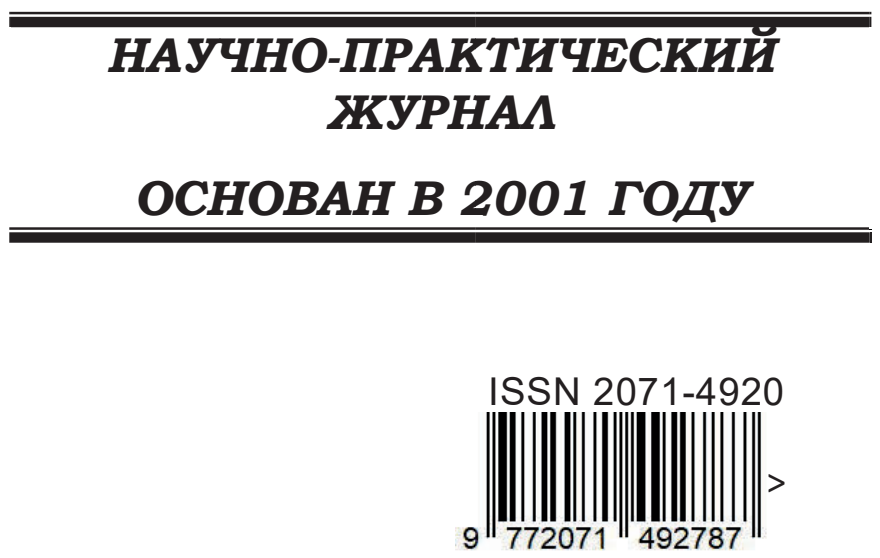

Журнал "Юридическая мысль» с 2010 г. входил

в ПЕРЕЧЕНЬ ведущих рецензируемых научных журналов и изданий,

в которых должны быть опубликованы основные научные результаты диссертаций на соискание ученой степени доктора и кандидата наук

\section{САНКТ-ПЕТЕРБУРГ}




\author{
Учредитемь и издатель \\ ЧОУ ВО «Юридический институт» (Санкт-Петербург) \\ Межрегиональная ассоциация теоретиков государства и права

\section{ГАавный редактор}

М.Б. Ревнова, ректор ЧОУ ВО “Юридический институт» (Санкт-Петербург), кандидат юридических наук

Заместитемь гмавного редактора

С.А. Комаров, президент Межрегиональной ассоциации

теоретиков государства и права,

научный руководитель ЧОУ ВО «Юридический институт» (Санкт-Петербург), доктор юридических наук, профессор,

заслуженный деятель науки и образования РАЕ

Ответственный секретарь редакционной коммегии

А.В. Яковмев, доцент кафедры теории и истории государства и права ЧОУ ВО «Юридический институт» (Санкт-Петербург), кандидат юридических наук

\title{
Редакционная комегия:
}

P.н. Дусаев, заведующий кафедрой общеправовых дисциплин юридического факультета Петрозаводского государственного университета, доктор юридических наук, профессор;

Т.ム. Комарова, проректор по науке и инновациям ЧОУ ВО “Юридический институт" (Санкт-Петербург), кандидат юридических наук, доцент;

Б.А. Ревнов, доцент кафедры конституционного и административного права ЧОУ ВО “Юридический институт" (Санкт-Петербург), кандидат юридических наук;

E.B. Середа, профессор кафедры уголовного права и процесса ЧОУ ВО «Юридический институт» (Санкт-Петербург), доктор юридических наук; профессор.

\section{Редакционно-издательский совет:}

С.А. Комаров, президент Межрегиональной ассоциации теоретиков государства и права, научный руководитель ЧОУ ВО “Юридический институт» (СанктПетербург), доктор юридических наук, профессор, заслуженный деятемь науки и образования РАЕ, председатель совета;

В.А. Винокуров, профессор кафедры теории и истории государства и прав ФГБУ ВО "Санкт-Петербургский университет ГПС МЧС России", Заслуженный юрист Российской Федерации, доктор юридических наук, профессор, чцен совета;

С.M. Воробьев, профессор кафедры теории государства и права, международного и европейского права Юридического факультета Академии ФСИН России, доктор юридических наук, профессор, чмен совета;

Ф.X. Гамиев, заведующий кафедрой теории государства и права Института права Башкирского государственного университета, доктор юридических наук, доцент, чиен совета;

А.М. Дроздова, профессор кафедры правовой культуры и защиты прав чемовека Северо-Кавказского федерацьного университета, доктор юридических наук, профессор, чиен совета;

Е.С.Ч. Ковамьски, директор Российской школы права Юридического факультета Университета Аазарского (UczelniŁazarskiego) в Варшаве, Республика 
Польша, доктор honoris causa ЧОУ ВО “Юридический институт" (Санкт-Петербург), доктор политических наук, профессор, член совета;

M.E. Kpук-Ярош (MariaKruk - Jarosz), заместитель декана по вопросам докторантуры Университета Аазарского (Uczelni Łazarskiego) в Варшаве, Республика Польша, доктор honoris causa ЧОУ ВО "Юридический институт" (СанктПетербург), доктор юридических наук, профессор, чмен совета;

Г.А. Мартьянов, доцент кафедры теории и истории государства и права ЧОУ ВО «Юридический институт» (Санкт-Петербург), кандидат юридических наук, чиен совета;

E.B. Мицкая, заведующая кафедрой уголовного права, процесса и криминамистики Южно-Казахстанского государственного университета им. М. Ауэзова (Республика Казахстан), доктор юридических наук, профессор, член совета;

Н.и. Помищук, вице-президент Межрегиональной ассоциации теоретиков государства и права, профессор кафедры теории государства и права, международного и европейского права Юридического факультета Академии ФСИН России, доктор юридических наук, профессор, член совета;

А.В. Попова, профессор Департамента правового регулирования экономической деятельности ФГОБУ ВО «Финансовый университет при Правительстве Российской Федерации" (Финансовый университет), доктор юридических наук, кандидат философских наук, доцент, чиен совета;

Г.С. Скачкова, зав. сектором трудового права и права социального обеспечения ФГБУН “Институт государства и права Российской академии наук", доктор юридических наук, профессор, чмен совета;

С.П. Стёпкин, доцент кафедры гражданско-правовых дисциплин Российского государственного социального университета, кандидат юридических наук, доцент, чмен Комиссии Ассоциации юристов России, чцен Совета;

Кари Сюнберг (Kari Synberg), профессор факультета общественных и экономических наук Университета Восточной Финляндии, член правления Географического общества Финляндии, доктор honoris causa Юридического института (Санкт-Петербург), доктор географических наук, чцен совета;

Н.А. Фролова, профессор кафедры теории государства и права им. Г.В. Мальцева ФГБОУ ВО “Российская академия народного хозяйства и государственной службы при Президенте Российской Федерации", доктор юридических наук, профессор, чиен совета.

\section{ПОДПиСКА}

в объединенном катахоге Пресса России "Подписка-2021"

Подписной индекс - 82596 (годовая подписка на 2021 г.)

Подписка в Агентстве: по тел. (499) 152-8850 и/или (495) 661-2030, по е-mail: arpk@akdi.ruarpk@bk.ruizdatcat@eg-online.ru

в Катапоге российской прессы "ПОЧТА РОССИИ"

Подписной индекс - 24220 (первое полугодие 2021 г.)

Журнал выходит 4 раза в год

Темефон редакции: (812) 325-98-90

Адрес в Интернете:http:/ / lawinst-spb.ru; http:/ / matgip.ru

E-mail: lawinst-spb@mail.ru; matgip2017@yandex.ru 
Founderand Publisher

Law Institute (St. Petersburg)

Interregional Association of Theorists of State and Law

Chief Editor

M.B. Revnova, Rector of the Law Institute (St. Petersburg), PhD

Deputy Chief Editor

S.A. Komarov, President of the Interregional Association of theoreticians of the state and law, scientific director

of the Law Institute (St. Petersburg), Doctor of Law, Professor, honored worker of science and education of RAE

Executive Secretary of the Editorial Board

A.V. Yakovlev, associate Professor of the Department of theory and history of state and law of the Law Institute

(St. Petersburg), PhD

\section{Editorial team:}

R.N. Dusaev, Head of common law disciplines Faculty of Law of Petrozavodsk State University, Doctor of Law, Professor;

T.L. Komarova, Vice-Rector for Science and Innovation of the Law Institute (St. Petersburg), PhD, associate professor;

B.A. Revnov, associate Professor of Department of constitutional and administrative law of law Institute (Saint Petersburg), $\mathrm{PhD}$;

E.V. Sereda, professor of criminal law and procedure of the Law Institute (St. Petersburg), Doctor of Law, Professor.

\section{Editorial and publishing Council:}

S.A. Komarov, President of the Interregional Association of theoreticians of the state and law, scientific director of the Law Institute (St. Petersburg), Doctor of Law, Professor, honored worker of science and education of RAE, Chairman of the Council;

V.A. Vinokurov, Professor of the Department of theory and history of state and rights of the "St. Petersburg University of Emercom of Russia", Honored lawyer of the Russian Federation, Doctor of law, Professor, member of the Council;

S.M. Vorobiev, Professor of the Department of theory of state and law, international and European law, faculty of Law, Academy of the FSIN of Russia, Doctor of law, Professor, member of the Council;

F.H. Galiev, Professor of Theory of State and Law of the Institute of Law of the Bashkir State University, Doctor of Law, associate professor, member of the Council;

A.M. Drozdova, professor of the Department of legal culture and protection of human rights of the North-Caucasus Federal University, Doctor of Law, Professor, member of the Council;

E.S.Ch. Kowalski, Head of the Russian law, professor of legal theory and legal logic, Deputy Dean of Science Faculty of Law of the University of Lazarski (Uczelni Łazarskiego) in Warsaw (Poland), Doctor honoris causa of the Law Institute (St. Petersburg), Doctor of Political Sciences, Professor, member of the Council;

M.E. Kruk-Jarosz (Maria Kruk-Jarosz), deputy dean for doctoral studies of the University of Lazarski (Uczelni Lazarskiego) in Warsaw (Poland), Doctor honoris causa of the Law Institute (St. Petersburg), Doctor of Law, Professor, member of the Council;

G.A. Martianov, associate Professor of the Department of theory and history of state and law of the Law Institute (St. Petersburg), candidate of law, member of the Council; 
E.V. Mitskaya, Head of the Department of Criminal Law, Criminology and process of the South Kazakhstan State University of Auezov (Kazakhstan), Doctor of Law, Professor, member of the Council;

N.I. Polishchuk, vice-president of the Interregional Association of theoreticians of State and Law, Professor of Theory of State and Law, International and European Law Faculty of Law of the Academy of the Federal Penitentiary Service of Russia, Doctor of Law, Professor, member of the Council;

A.V. Popova, a professor of the Department of legal regulation of economic activity, Financial University under the Government of the Russian Federation, Doctor of Law, Ph.D., associate professor, member of the Council;

G.S. Skachkova, Head sector labor law and social security law of the "Institute of State and Law of the Russian Academy of Sciences", Doctor of Law, Professor, member of the Council;

S.P. Stepkin, associate Professor of the Department of civil law disciplines of the Russian state social University, Candidate of law, associate Professor, member of the Commission of the Association of lawyers of Russia, member of the Council;

Soili Nystén-Haarala, Professor of Commercial Law, University of Lapland, Faculty of Law (Republic of Finland), Doctor of Law, Professor, member of the Council;

Kari Syunberg (Kari Synberg), professor of the Faculty of Social and Economic Sciences of the University of Eastern Finland, a board member of the Geographical Society of Finland, the Republic of Finland, Ph.D Geography, Doctor honoris causa of the Law Institute (St. Petersburg), Professor h.c., member of the Council;

N.A. Frolova, a professor of the Department of Theory of State and Law named by G.V. Maltsev of "Russian Presidential Academy of National Economy and Public Administration", Doctor of Law, Professor, member of the Council.

\section{Информация дия авторов:}

Ваши материалы (объемом до 0,6-1,0 усл.-печ. м.) направцяйте по адресу: 199106, Санкт-Петербург, ум. Гаванская, 3 Юридический институт (Санкт-Петербург) Тем. (812) 325-4625. E-mail: lawinst-spb@mail.ru 119415, г. Москва, ум. Удальцова, дом 19, корп. 1, оф. 12 MOO "Межрегиональная ассоциация теоретиков государства и права" Tes. (499) 431-5806. E-mail: matgip2017@yandex.ru Каждая статья должна сопровождаться реиензией! Просьба указывать свою должность, ученую степень, звание, фамилию, имя и отчество, почтовый адрес и телефон.

Свидетецьство о регистрации ПИ № 2-4890 от 15 декабря 2000 г.

Формат 80x108/16. Подписано в печать 16.12.2021. Бумага офсетная. Печать офсетная. Уч.-изд. м. 26,42. Усм. п.л. 15,5. Тираж 100 экз. Заказ №

Отпечатано в типографии "OneBook.ru" ООО "Сам Полиграфист" 109316, г. Москва, Волгоградский проспект, дом 42, корпус 5, «Технополис».

(C) «Юридическая мысль», № 4 (124), 2021 На обложке - фрагмент картины С. Дали "Рафаэлевская голова, разцетающаяся на куски" (1951) 


\section{Юридическая мысль}

\section{1 НАУЧНО-ПРАКТИЧЕСКИЙ ЖУРНАА ОСНОВАН В 2001 ГОДУ \\ $4(124)$}

\section{СОДЕРЖАНИЕ}

\subsection{1. ТЕОРЕТИКО-ИСТОРИЧЕСКИЕ ПРАВОВЫЕ НАУКИ}

\section{(12.00.01 - Теория и история права и государства; история учений о праве и государстве)}

Алексеева А.А., Волобуева О.А.

Президент как особая четвертая ветвь вцасти в России

Васильев Г.В.

Финансовая политика, как инструмент обеспечения

устойчивого развития региона

Глазков В.А., Аевченков А.И.

«Устойчивое развитие»: проблемы и перспективы

Грунин А.Г., Муравлева А.Ю.

Некоторые предпосылки для фрормирования понятия

квазиправоохранительные органы

Корякин И.И.

Оптимизация организационного обеспечения деятельности судов:

теория и практика правового регулирования

Muикая E.B.

Размышияя о достижении эффективности

нормативных правовых актов

Петрунина А.А.

Информационные права в сфере здравоохранения

Прокопович Г.А. Коррупция как проблема на пути устойчивого развития человечества в XXI веке

Прокофьев К.Г., Иванов Д.В.

«Теория принципов" Рональда Дворкина - «третий путь»

в теории права?.

Фролова Н.А.

Наркобезопасное общество как определяющий фактор

современного этапа социального развития России 
Шеркунов С.А.

Наукограды России: современное состояние и перспективы развития.

\subsection{4. УГОАОВНО-ПРАВОВЫЕ НАУКИ}

\section{(12.00.08 - Уголовное право и криминология; угомовно-исполнитеАьное право)}

Гареев М.Ф.

Уголовно-правовое воздействие: понятие и правовая природа

Гареев М.Ф.

Уголовно-правовое воздействие и уголовная ответственность

\section{В ПОМОЩЬ ПРЕПОДАВАТЕАЮ}

Бастрыкин А.И.

Аекция: О средствах обеспечения безопасности и противодействия терроризму

\section{ПЕРСОНАМИИ}

Комаров С.A.

Виктору Васильевичу Бородину исполнимось 65 мет

Сальников В.П., Комаров С.А., Кондрат И.Н., Хабибулин А.Г.

Сергею Ивановичу Захарцеву исполнимось 45 мет 


\section{CONTENT}

\subsubsection{THEORETICAL AND HISTORICAL LEGAL SCIENCES}

\section{(12.00.01 - Theory and history of law and state;}

history of doctrines about law and state)

Alekseeva A.A., Volobueva O.A.

President as a special fourth branch of government in Russia

Vasiliev G.V.

Financial policy as a tool for ensuring sustainable development of the region .....

Glazkov V.A., Levchenkov A.I.

"Sustainable development": problems and prospects

Grunin A.G., Muravleva A.Yu.

Origins of formation of the concept quasi law enforcement bodies

Koryakin I. I.

Organizational support optimization activities of vessels: theory and practice

of legal regulation

Mitskaya E.V.

Reflecting on achieving the effectiveness of regulatory acts

Petrunina A.A.

Health information rights

Prokopovich G.A.

Corruption as a problem for sustainable human development

in the twenty-first century

Prokofiev K.G., Ivanov D.V.

Ronald Dvorkin's "Theory of Principles" - "The Third Way"

in the Theory of Law?

Frolova N.A.

Drug-safe society as a determining factor of the modern stage

of social development of Russia

Sherkunov S.A.

Russian science cities: current state and development prospects

\subsubsection{CRIMINAL SCIENCES}

(12.00.08 - Criminal Law and Criminology; Penal law)

Gareev M.F.

Criminal law impact: concept and legal nature 
Gareev M.F.

Criminal law impact and criminal liability

\section{TO HELP THE LECTURER}

Bastrykin A.I.

Lecture: On the means of ensuring security and countering terrorism.

\section{PERSONNEL}

Komarov S.A.

Viktor Vasilyevich Borodin is 65 years old

Salnikov V.P., Komarov S.A., Kondrat I.N., Khabibulin A.G.

Sergey Ivanovich Zakhartsev is 45 years old 


\section{Индексация журнала}

\section{НАУЧНАЯ ЭЛЕКТРОННАЯ

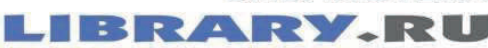 \\ OLRICHSWEB'm GLOBAL SERIALS DIRECTORY}

\section{doi) 5 crossref}

В номере пубинкуются материалы:

\section{ДЕНИСОВСКИЕ ЧТЕНИЯ}

VI Международная научно-теоретическая конференция

"Чемовек-природа, иичность-общество, гражданингосударство

в условиях информатизации и цифровизации российского общества

в интересах устойчивого развития"

VI International Scientific Conference

"Man-nature, personality-society, citizen-state in the context of informatization and digitalization of Russian society in the interests

of sustainable development"

12 октября 2021 года 


\section{Информационные партнеры}

\author{
Журнал \\ «Теория \\ государства \\ и права"
}

Вестник

Костромского государственного университета

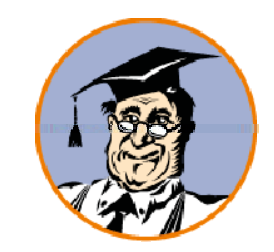

Компания

«Консультант-

Пцюс"

\author{
Журнал \\ «Юридическая \\ наука"
Журнал
«Современное рос-
сийское право"
Журнал «Вестник общей и отраслевой теории права"

Журнал
«урнал
праврационное

Журнал

«Вестник

Института права

БашГУ"

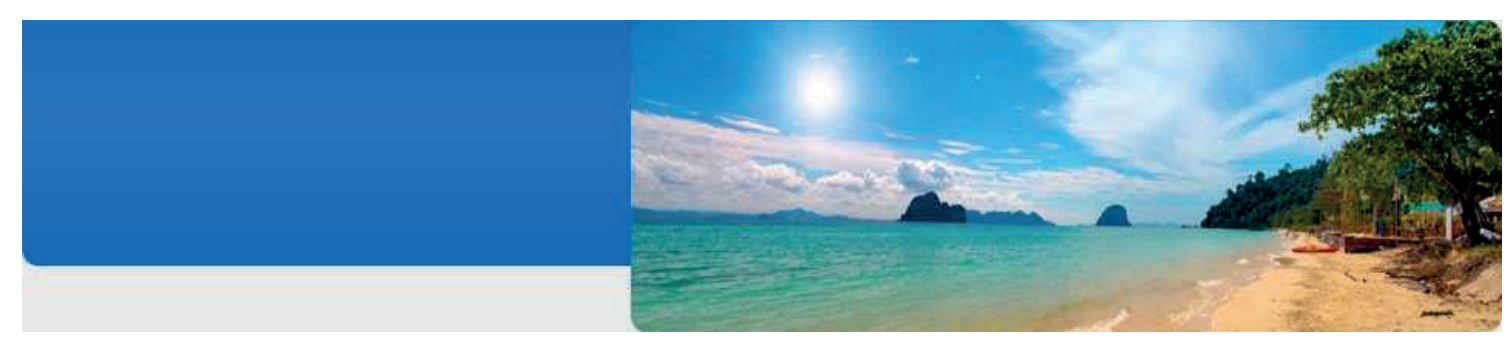

Журнал

«Dilemas contemporaneos-educacion politica y valores» (Мексика) 


\title{
5.1.1. ТЕОРЕТИКО-ИСТОРИЧЕСКИЕ ПРАВОВЫЕ НАУКИ
}

\author{
(12.00.01 - Теорня н нсторня права \\ н ГОСУ(АарСТВа; нстОрНЯ Ученнй \\ - праве н госіАарстве)
}

\author{
Удк 340 \\ ББK 67.0 \\ DOI: $10.47905 /$ MATGIP.2021.124.4.001
}

\section{ПрЕЗНАЕНТ КАК ОСОБАЯ чЕТВЕРТАЯ ВЕТВЬ ВААСТН В Росснн}

\author{
a. а. Алексеева* \\ o.A. Bоловуева ${ }^{* *}$
}

\begin{abstract}
Аннотация. Данная статья посвящена особому пути России в формировании государственной власти, отличию её от классической концепции Дж. Аокка

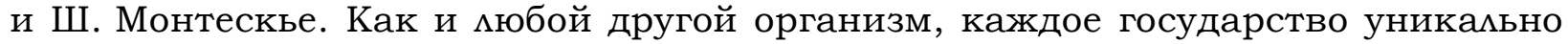
и имеет свои особенности. Авторы на основе сравнительно правового анализа нормативных правовых актов XVIII-XXI вв., а также научных трудов мыслитемей исследуемых исторических этапов развития государственности, приходят к выводу об эвоцюционном развитии статуса президента и становцении его на современном этапе в качестве особой четвертой ветви государственной вцасти.

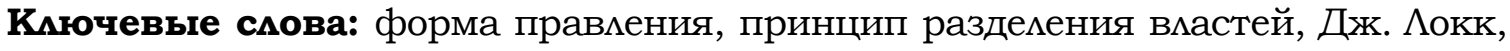
Ш. Монтескье, система сдержек и противовесов, государь, президент.
\end{abstract}

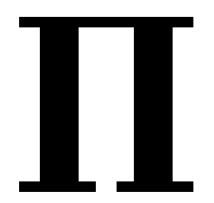

ринцип разделения вмастей ими, как его обосновывали основоположники теории - принцип распределения властей (выделено нами - A.A., О.В.), призван играть главенствующую роль при осуществцении государственной вцастью своих основных функций. При этом нельзя представить организацию формы

* Алексеева Анастасия Алексеевна, студент юридического факультета ФГОБУ ВО "Финансовый университет при Правительстве Российской Федерации», г. Москва, Россия. E-mail: nastya_alex13@mail.ru

** Волобуева Ольга Александровна, студент юридического факультета ФГОБУ ВО "Финансовый университет при Правительстве Российской Федерации», г. Москва, Россия. E-mail: volobueva889@gmail.com

Научный руководитель - Попова Анна Владиславовна, профессор департамента международного и публичного права Юридического факультета ФГОБУ ВО “Финансовый университет при Правитемьстве Российской Федерации", доктор юридических наук, кандидат фимософских наук, доцент. E-mail: anna0710@yandex.ru 
государственного правления современной России без осуществления данного принципа. Впервые законодательно он был закреплен в ст. 10 Конституции Российской Федерации 1993 г. [1], однако попытки его реамизации на практике можно уже проследить в 1906 году, в тексте "Высочайше утвержденных Основных Государственных Законах Российской Империи" [2].

Впервые принцип разделения властей был сформулирован в XVIII в. английским философом и юристом Джоном Аокком. В работе "Два трактата о правлении" он указывает на наличие трёх ветвей власти: законодательной, исполнительной и федеративной [3]. Каждой ветви вмасти он приписывает опредеменные характеристики и функции. Так Дж. $\Lambda$ окк опреде-

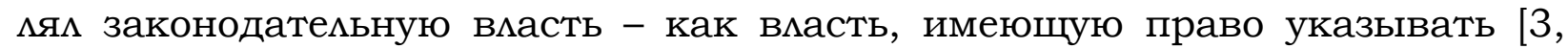
с. 143], исполнительную, как власть, которая следила бы за исполнением тех законов, которые созданы и остаются в силе [3, с. 144], федеративную, «как власть, включающую в себя руководство внешней безопасностью и интересами общества в отношениях со всеми теми, от кого оно может получить выгоду или потерпеть ущерб" [3, с. 147]. При этом он также отмечает взаимосвязь этих ветвей вмасти и необходимость в определенной мере сосредоточить исполнительную и федеративную власть в руках одних миц [3, с. 148], а законодательную власть передавать в руки разцичных миц [3, с. 143] для блага государства. В продолжении данной концепции Шарль Ауи де Монтескьё, в труде "О духе законов" уже подразделяет власть на исполнительную, законодательную и судебную [4]. При этом необходимость раздемения вмастей он обосновывал необходимостью создать такое правление, при котором гражданин может оставаться уверенным в своей безопасности.

Данная теория разделения (распределения) властей получила свое развитие в трудах французских и английских мыслителей уже в XIX в. При этом, полагаем, что для России, в сицу ее исторических особенностей, более применима концепция Бенжамена Констана, изложенная в его труде "Принципы политики, пригодные дмя всякого правления" [5]. Во второй главе данной работы он выделяет пять видов власти: королевскую вцасть, исполнительную власть, устойчивую представительную власть, представительную власть мнения и судебную власть, говоря также о необходимости

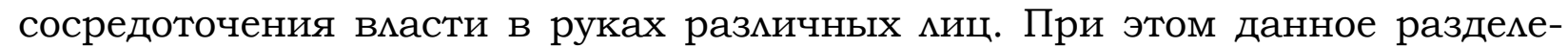
ние властей должно было осуществляться в условиях конституционной монархии и отводить королевской власти особую роль. Так, по концепции Б. Констана, первые две власти должны были издавать законы, третья вмасть заботиться об их общем исполнении, четвертая применяет законы к частным случаям. Королевская вцасть находится между этими вцастями, но при этом она выше их, главная задача, которой явцяется поддержание равновесия. Гцава государства выступал нейтральной властью, цель которой во взаимопонимании, взаимной поддержки и согмасных действиях остальных ветвей вцасти. При этом важно отметить, что глава государства не домжен подменять собой другие власти, его главная роль заключатся в необходимости поддерживать основные ветви власти, приводить их в порядок, если вмасти пересекаются ими мешают друг другу [5]. 
Следует подчеркнуть, что основополагающую роль в процессе формирования и нормативного закрепления принципа разделения властей в России сыграл М. М. Сперанский. В его трудах явно прослеживается

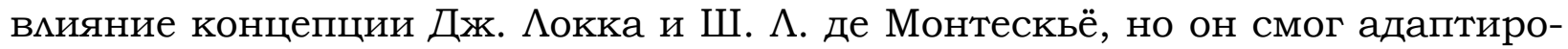
вать данные концепции под специфику нашего государства. Во введении к УАожению государственных законов отдельно выделены функции Государственной Думы, как высшего законодательного органа, Сената, как высшего судебного органа, Государственного Совета, как высшего органа управления [6]. В данном проекте сказано о необходимости данной реформы, потому что безграничная вцасть императора "имеет некоторые умственные границы, мнением, привычкою", для развития общества необходимо наличие у мюдей не только гражданских прав, но и политических ("истинные права гражданские должны быть основаны на правах политических, точно так же, как и закон гражданский вообще не может быть тверд без закона политического") [6]. А дмя этого необходимо четко обозначить и разграничить функции императора и других органов государственной власти.

Данные права и обязанности становятся главным предметом состава "коренного закона" (непоколебимая воля народа, ограничивающая влияние самодержавной власти и явцяющаяся "первым источником силы правительства"). М. М. Сперанский выделиц права державной власти, закон, возникающий из прав державной власти, что положило начало к установлению принципа раздемения вцастей на законодательную, исполнительную и судебную ветви власти в правовой реальности XIX в. ВАияние М. М. Сперанского на становцение общественной мысли было высоко, многие его проекты быми реализованы, но консервативное окружение Императоров А^ександра I и Николая I не позволило воплотить это масштабное преобразование государственного аппарата. К этому проекту вернулись только 1906 г. при учреждении Первой Государственной Думы.

Труды М. М. Сперанского нашии свое отражение и в конституционных законопроектах декабристов. Так, проект Конституции Российской Империи Н. М. Муравьева тесно связаны с идеями демократизация российского общества [7]. По проекту предиагаемой им конституции, найденного в бумагах С. П. Трубецкого, крестьяне освобождались от крепостной зависимости [7, гц. 3 ст. 13], так как по его Основному закону источником Верховной власти является народ [7, гл. 1 ст. 2], а зависимый народ таковым быть не может. Основываясь на найденных записях, можно сказать, что по его концепции вводимось разделение властей. При этом законодательная власть принадлежала Народному вече, оно в свою очередь состояло из двух палат Верховной Думы и Палаты Представителей [7, гл. 10]. Органами первого уровня исполнительной вцасти выступали четыре министерства: министерство финансов, иностранных дец, военное и морское. Второй уровень - это представительство на местах, местное управление во главе с областным представителем. Гцавой же исполнительной вцасти предпомагался Государь-император. Н. М. Муравьев своим проектом конституции стремился привести Россию к конституционной монархии и реализовать в государственном устройстве демократические принципы. П. И. Пестель так- 
же стремился реализовать принцип разделения властей в своем проекте "Русская правда", только в нем верховная власть принадлежала Державной Думе, которая дополнялась министерствами, а формой правления предлагалась республика [8].

В конце XIX - начале XX вв. во время правления Николая II был $е$ гально обоснован принцип разделения властей на законодательную исполнительную и судебную именно в том формате, который знаком нам сейчас. Известные юристы того времени - Г. Ф. Шершеневич, Н. $\Lambda$. Дювернуа, $\Lambda$. А. Кассо, Е. А. Нефедьев и др. - обобщили опыт предыдущих мыслителей и предлагали обособить роль императора от остальных ветвей власти, что и было отражено в сначала в Проекте основного закона Российской Империи 1905 года [9], а после в Своде основных государственных законов [2].

Правовое положение Императора по Проекту основного закона Российской Империи [9] было сформулировано в ст. 1, где ему принадлежала Верховная Самодержавная власть. Что подтверждает концепцию Констана о власти императора (короля), как органа регулирующего, поддерживающего равновесие, но при этом со стороны Николая II все еще наблюдались попытки ограничить законодательную власть в мице Государственной Думы, занять главенствующую позицию, за императором были закреплены обширные полномочия в осуществлении законодательной власти (ст. 31, ст. 32). Так что о полной реализации данной теории на данном этапе нам говорить не приходится. Император утверждал законы (ст. 31) мог распустить Государственную Думу (ст. 32), но, с другой стороны, он быц ограничен в праве единолично осуществлять законодательную власть: в проекте было прописано, что Император осуществляет Верховную власть при участии Государственной Думы (ст. 1). Это позволяет сделать вывод о том, что Император обладал отнюдь не неограниченной вмастью, несмотря на довольно широкие полномочия.

Полномочия Императора в отношении исполнительной власти были довольно обширны. Помимо того, что Император назначал и увольнял министров (ст. 33), он также является верховным начальствованием сухопутных и морских вооруженных сил Российской державы (ст. 34), жаловал чины (ст.34), ему принадмежало право помимования и смягчения наказаний (ст. 35). Несмотря на обширный круг полномочий Императора ни один его указ не мог быть опубцикован без подписи министров (ст. 29).

В дальнейшем идеи революционной демократии, о которых мы говорими ранее, взяли верх над идеей конституционной монархии [10; 11]. Государственная Дума не хотела мириться с ограничениями, которые ставимись императором. Возрастала социальная напряженность, из-за ряда причин авторитет Николая II стремительно падал. И после событий 1917 г. к вопросу о необходимости регламентации в тексте конституции принципа разделения властей вернулись в 1991 г.

В тексте Конституции Российской Федерации 1993 г. (далее по тексту Конституция РФ) законодательно закреплены принципы разделения властей и система сдержек и противовесов. [1]. Правовое положение Президента Российской Федерации (далее по тексту - Президент РФ, Президент России) четко определено в ст. 80 Конституции РФ. В соответствии с этой 
статьей Президент выступает в роли главы государства (ч. 1. ст. 80) и не входит ни в одну из трёх известных нам ветвей вцастей (ч. 2 ст. 80). Однако основываясь на исследованиях Б. Констана, выше приведенных нами, следует отметить, что по формулировкам главы 4 мы можем сделать вывод о законодательном закреплении четвёртой ветви вцасти - власти главы государства, который в соответствие с идеями французского мысмителя выступает связующим звеном в деятельности органов государственной власти [12].

Законодательные полномочия Президента РФ частично схожи с полномочиями Императора Российской империи, так Президент РФ назначает выборы в Государственную Думу, может распустить ее при определённых обстоятельствах, а также подписывает и обнародует федеральные законы, то есть "утверждает законы" (п. "а", "б", "д" ст. 84). Согласно п. "Г" ст. 84 Президент РФ обладает правовым законодательной инициативы, он может вносить законопроекты в Государственную Думу, а также обращается к Федеральному Собранию с ежегодными посланиями не только о положении в стране, но и конкретными законотворческими проектами (п. "Г» и “е» ст. 84). По ч. 3 ст. 107 Президент РФ обладает правом вето, но следуя определённому алгоритму действий Государственная Дума способна преодолеть президентское вето.

По Конституции РФ Президент России не является главой исполнительной власти, но наделён определёнными полномочиями в осуществ ении и координации деятельности органов исполнительной власти. Согласно Конституции РФ, Президент России не только участвует в формировании Правительства Российской Федерации (далее по тексту - Правительство), но и осуществляет общее руководство Правительством (п. б ст. 83) и в рамках реализации этой функции предмагает Государственной Думе Федерального Собрания Российской Федерации (далее по тексту - Государственная Дума) кандидатуру для назначения на домжность председателя правительства (п. "а" ст. 83), заместителей Председателя Правительства Российской Федерации, федеральных министров, а также руководителей федеральных органов исполнительной вцасти (п. 1 ст. 83).

Конституция РФ даёт Президенту РФ право председательствовать на заседаниях Правительства (п. б ст. 83), он согласно ч. 2 ст. 85, вправе остановить действие нормативно-правовых актов исполнительной власти субъектов Российской Федерации, если нормы, содержавшиеся в них, противоречат Конституции и другим, вышестоящим по юридической силе, актам до того, пока этот вопрос не решит суд. В соответствии с пунктом в ст. 89 Президент РФ осуществляет помилование, тем самым участвуя в деятельности судебной вмасти. Также он представцяет Совету Федерации кандидатуры для назначения на должность судей Конституционного Суда Российской Федерации, судей Верховного Суда Российской Федерации; назначает председателей, заместителей председателей и судей других федеральных судов (п. «е» ст. 83).

Как мы видим действующие полномочия Президента соответствуют представцению Б. Констана о распределении полномочий между ветвями власти, и его теория действительно работает в рамках законодательства 
нашей страны. Такое пропорциональное делегирование полномочий между Правительством, Президентом и Советом Федерации, а также судебной властью позволяет в первую очередь сохранить и правицьно реализовывать принцип суверенитета народа [5].

Таким образом, государственный строй нашей страны прошёл огромный путь модернизации, дия того чтобы мы законодательно нашли оптимальную форму государственного устройства.

\section{Бибциографический список}

1. «Конституция Российской Федерации" (принята всенародным голосованием 12.12.1993 с изменениями, одобренными в ходе общероссийского голосования 01.07.2020) // Официальный интернет-портал правовой информации http:/ / www.pravo.gov.ru, 04.07.2020.

2. Российская Империя. Законы (1906 год). Высочайшее утвержденные Основные Государственные Законы // Полное собрание законов российской империи. Т. 26, отдемение 1. 1906 ственный.

3. Аокк, Дж. Два трактата о правмении / 1683. - 85-87 с. - Текст: непосредвенный.

4. Монтескъе Ш. О духе законов / 1748. - 146-159 с. - Текст: непосредст-

5. Констан Б. Принципы политики, пригодные для всякого правления / 1815. - 37- с. - Текст: непосредственный.

6. Сперанский M.M. Введение к уможению государственных законов / [Эмектронный ресурс] // URL: https://constitution.garant.ru/history/act1600$1918 / 3848894 /$

7. Муромиев С.A. Проект основного закона Российской империи (1905) / [Эмектронный ресурс] URL: http:// музейреформ.pф/node/13705

8. Пестель П.И. Русская Правда или Заповедная Государственная Грамота Великого Народа Российского служащая Заветом для Усовершенствования Государственного Устройства России и Содержащая Верный Наказ как для Народа, так и для Верховного Правления (1823) / [Эмектронный ресурc] URL: http:/ / www.rusconstitution.ru/library/constitution/articles/9423/

9. Основной Государственный Закон Российской Империи: Проект русской конституции, выработанный группой чценов Союза Освобождения / [Эмектронный pecypc] // URL: https://allpravo.ru/library/doc313p/instrum3155/ item3157.html

10. Попова А.В. Аиберализм и неолиберализм в правовом измерении России на рубеже XIX-XX вв. // Журнал российского права. - 2011. - № 4(172). - С. 105113.

11. Попова А.В. Неолиберальная модемь государственного и общественного устройства России на рубеже XIX-XX вв.: монография. - М.: Юрлитинформ, 2012. 229 c.

12. Комментарий к Конституции Российской Федерации / Комаров С.А., Дроздова А.М., Полищук Н.И. и др.; под ред. С.А. Комарова. - М.: Юрайт, 2019. Сер. «Профессиональные комментарии» (3-е изд., пер. и доп). - 333 с.

Дия цитирования: Алексеева А.А., Волобуева О.А. Президент как особая четвертая ветвь власти в России: статья // Юридическая мысль. - 2021. - № 4 (124). - С. $12-17$.

DOI: $10.47905 /$ MATGIP.2021.124.4.001 


\title{
President as a special fourth branch of government in Russia
}

\section{Anastasia A. Alekseeva* Olga A. Volobueva**}

\begin{abstract}
Annotation. This article is devoted to the special path of Russia in the formation of state power, its difference from the classical concept of J. Locke and C. Montesquieu. Like any other organism, each state is unique and has its own characteristics. Based on a comparative legal analysis of normative legal acts of the 18th 21 st centuries, as well as scientific works of thinkers of the studied historical stages of statehood development, the authors come to the conclusion about the evolutionary development of the status of the president and its formation at the present stage as a special fourth branch of state power.
\end{abstract}

Key words: form of government, principle of separation of powers, J. Locke, C. Montesquieu, system of checks and balances, sovereign, president.

The principle of separation of powers, or, as the founders of the theory substantiated it, the principle of the distribution of powers (highlighted by us A.A., O.V.), is called upon to play a dominant role in the implementation of its main functions by the state power. At the same time, it is impossible to imagine the organization of the form of government in modern Russia without the implementation of this principle. For the first time, it was legislatively enshrined in Art. 10 of the Constitution of the Russian Federation of 1993 [1], however, attempts to implement it in practice can already be traced in 1906, in the text of the "Supremely approved Basic State Laws of the Russian Empire" [2].

The principle of separation of powers was first formulated in the 18th century. English philosopher and lawyer John Locke. In his work "Two Treatises on Government", he indicates the presence of three branches of government: legislative, executive and federal [3]. He assigns certain characteristics and functions to each branch of government. So J. Locke defined the legislative power - as the power that has the right to indicate [3, p. 143], executive, as a power that would monitor the implementation of those laws that are created and remain in force [3, p. 144], federal, "as a government that includes the management of external security and the interests of society in relations with all those from whom it can benefit or suffer damage" [3, p. 147]. At the same time, he also notes the interconnection of these branches of power and the need to a certain extent to concentrate the executive and federal power in the

* Alekseeva Anastasia Alekseevna, student of the Faculty of Law of the Federal State Educational Institution of Higher Education "Financial University under the Government of the Russian Federation", Moscow, Russia. E-mail: nastya_alex13@mail.ru

** Volobueva Olga Aleksandrovna, student of the Faculty of Law of the Federal State Budgetary Educational Institution of Higher Education "Financial University under the Government of the Russian Federation", Moscow, Russia. E-mail: volobueva889@gmail.com

Academic Supervisor - Popova Anna Vladislavovna, Professor of the Department of International and Public Law of the Faculty of Law of the Federal State Educational Institution of Higher Education "Financial University under the Government of the Russian Federation", Doctor of Law, Candidate of Philosophy, Associate Professor. E-mail: anna0710@yandex.ru 
hands of one person [3, p. 148], and to transfer the legislative power into the hands of various persons [3, p. 143] for the good of the state. In continuation of this concept, Charles Louis de Montesquieu, in his work "On the Spirit of Laws", already divides power into executive, legislative and judicial [4]. At the same time, he justified the need for separation of powers by the need to create such a board in which a citizen can remain confident in his security.

This theory of the division (distribution) of powers was developed in the works of French and English thinkers already in the 19th century. At the same time, we believe that for Russia, due to its historical characteristics, the concept of Benjamin Constant, set forth in his work "The principles of politics suitable for any government" [5], is more applicable. In the second chapter of this work, he identifies five types of power: royal power, executive power, stable representative power, representative power of opinion and judicial power, speaking also about the need to concentrate power in the hands of various persons. At the same time, this division of powers was to be carried out in conditions of constitutional monarchy and to assign a special role to the royal power. So, according to B. Konstan's concept, the first two authorities were supposed to issue laws, the third power was to take care of their general implementation, the fourth applies laws to special cases. Royal power is between these authorities, but at the same time it is higher than them, the main task of which is to maintain equilibrium. The head of state acted as a neutral government, the purpose of which was mutual understanding, mutual support and concordant actions of the other branches of government. It is important to note that the head of state should not substitute for other authorities, his main role is to support the main branches of government, to bring them into order if the authorities overlap or interfere with each other [5].

It should be emphasized that M.M.Speransky played a fundamental role in the process of formation and normative consolidation of the principle of separation of powers in Russia. In his works, the influence of the concept of J. Locke and C.L. de Montesquieu is clearly traced, but he was able to adapt these concepts to the specifics of our state. In the Introduction to the Code of State Laws, the functions of the State Duma, as the highest legislative body, the Senate, as the highest judicial body, the State Council, as the highest governing body, are separately identified [6].

This project says about the need for this reform, because the unlimited power of the emperor "has some mental boundaries, opinion, habit", for the development of society, people need not only civil rights, but also political ("true civil rights must be based on political rights, just like a civil law cannot be firm without a political law") [6]. And for this it is necessary to clearly define and delineate the functions of the emperor and other bodies of state power.

These rights and obligations become the main subject of the composition of the "root law" (the unshakable will of the people, limiting the influence of autocratic power and being the "first source of government power"). M. M. Speransky singled out the rights of sovereign power, the law arising from the rights of sovereign power, which marked the beginning of the establishment of the principle of the separation of powers into legislative, executive and judicial branches of power in the legal reality of the 19th century. The influence of 
M. M. Speransky on the formation of social thought was high, many of his projects were implemented, but the conservative environment of the Emperors Alexander I and Nicholas I did not allow this large-scale transformation of the state apparatus to be implemented. This project was returned only in 1906 when the First State Duma was established.

The works of M. M. Speransky were reflected in the constitutional bills of the Decembrists. Thus, the draft Constitution of the Russian Empire by N.M. Muravyov is closely related to the ideas of democratization of Russian society [7]. According to the draft constitution he proposed, found in the papers of S.P. Trubetskoy, the peasants were freed from serfdom [7, Ch. 3 tbsp. 13], since according to its Basic Law the people are the source of the Supreme Power [7, Ch. 1 tbsp. 2], and a dependent people cannot be like that. Based on the records found, we can say that according to his concept, a separation of powers was introduced. At the same time, the legislative power belonged to the People's Council, which, in turn, consisted of two chambers of the Supreme Duma and the House of Representatives [7, Ch. 10].

The organs of the first level of executive power were four ministries: the ministry of finance, foreign affairs, military and naval. The second level is local representation, local government headed by a regional representative. The Emperor was supposed to be the head of the executive branch. N.M. Muravyov, with his draft constitution, strove to bring Russia to a constitutional monarchy and to implement democratic principles in the state structure. P.I. Pestel also sought to implement the principle of separation of powers in his project "Russkaya Pravda", only in it the supreme power belonged to the State Duma, which was supplemented by ministries, and a republic was proposed as a form of government [8].

In the late XIX - early XX centuries during the reign of Nicholas II, the principle of separation of powers into legislative, executive and judicial powers was legally substantiated in the format that is familiar to us now. Well-known lawyers of that time - G.F.Shershenevich, N.L.Duvernoy, L.A. Kasso, E.A. Nefediev summarized the experience of previous thinkers and proposed to isolate the role of the emperor from other branches of government, which was reflected in the first draft of the basic law of the Russian Empire in 1905 [9], and then in the Code of Basic State Laws [2].

The legal status of the Emperor under the Draft Basic Law of the Russian Empire [9] was formulated in Art. 1, where he belonged to the Supreme Autocratic power. This confirms B. Konstan's concept of the power of the emperor (king) as a regulatory body that maintains the balance, but at the same time, there were still attempts by Nicholas II to limit the legislative power in the person of the State Duma, to take a dominant position, the emperor was consolidated extensive powers in the exercise of legislative power (Art. 31, Art. 32). So we don't have to talk about the full implementation of this theory at this stage.

The Emperor approved laws (Article 31) could dissolve the State Duma (Article 32), but on the other hand he was limited in the right to exercise legislative power alone: the draft stipulated that the Emperor exercises Supreme power with the participation of the State Duma (Article 1). This allows us to conclude that the Emperor possessed by no means unlimited power, despite rather broad powers. 
The powers of the Emperor in relation to the executive branch were quite extensive. In addition to the fact that the Emperor appointed and dismissed ministers (Article 33), he is also the supreme command of the land and naval armed forces of the Russian state (Article 34), pardon and mitigation of punishment (Article 35). Despite the extensive terms of reference of the Emperor, none of his decrees could be published without the signature of the ministers (Art. 29).

In the future, the ideas of revolutionary democracy, which we talked about earlier, prevailed over the idea of constitutional monarchy $[10 ; 11]$. The State Shock Duma did not want to put up with the restrictions imposed by the emperor. Social tension increased, due to a number of reasons, the authority of Nicholas II was rapidly falling. And after the events of 1917 , they returned to the question of the need for regulation in the text of the constitution of the principle of separation of powers in 1991.

In the text of the Constitution of the Russian Federation of 1993 (hereinafter referred to as the Constitution of the Russian Federation), the principles of separation of powers and the system of checks and balances are legislatively enshrined [1]. The legal status of the President of the Russian Federation (hereinafter referred to as the President of the Russian Federation, the President of Russia) is clearly defined in Art. 80 of the Constitution of the Russian Federation. In accordance with this article, the President acts as the head of state (part 1 of article 80) and is not included in any of the three branches of government known to us (part 2 of article 80). However, based on the studies of B. Constant, cited above, it should be noted that, according to the wording of Chapter 4, we can conclude that the fourth branch of power is legislatively consolidated - the power of the head of state, which, in accordance with the ideas of the French thinker, acts as a liaison link in the activities of public authorities [12].

The legislative powers of the President of the Russian Federation are partially similar to the powers of the Emperor of the Russian Empire, as the President of the Russian Federation calls elections to the State Duma, can dissolve it under certain circumstances, and also signs and promulgates federal laws, that is, "approves laws" (clause "a" , "B", "d" Art. 84).

According to paragraph "g" of Art. 84 The President of the Russian Federation has a legal legislative initiative, he can submit bills to the State Duma, and also appeals to the Federal Assembly with annual messages not only about the situation in the country, but also specific legislative projects (paragraphs "d" and "f" of Art. 84 ). Under Part 3 of Art. 107 The President of the Russian Federation has the right to veto, but following a certain algorithm of actions, the State Duma is able to overcome the presidential veto.

According to the Constitution of the Russian Federation, the President of Russia is not the head of the executive branch, but is endowed with certain powers in the implementation and coordination of the activities of executive bodies. According to the Constitution of the Russian Federation, the President of Russia not only participates in the formation of the Government of the Russian Federation (hereinafter referred to as the Government), but also exercises general leadership of the Government (clause b, Article 83) and, as part of this 
function, proposes to the State Duma of the Federal Assembly of the Russian Federation ( hereinafter referred to as the State Duma) a candidate for appointment to the post of the chairman of the government (clause "a" of article 83), deputy chairmen of the Government of the Russian Federation, federal ministers, as well as heads of federal executive bodies (clause 1 of article 83).

The Constitution of the Russian Federation gives the President of the Russian Federation the right to preside over meetings of the Government (clause b, art. 83), according to part 2 of art. 85, has the right to stop the operation of regulatory legal acts of the executive power of the constituent entities of the Russian Federation, if the norms contained in them contradict the Constitution and other higher legal acts until this issue is resolved by the court. In accordance with paragraph in Art. 89 The President of the Russian Federation grants a pardon, thereby participating in the activities of the judiciary. He also submits candidates to the Federation Council for appointment as judges of the Constitutional Court of the Russian Federation, judges of the Supreme Court of the Russian Federation; appoints presidents, deputy presidents and judges of other federal courts (item "e" Article 83).

As we can see, the current powers of the President correspond to the idea of B. Konstan on the distribution of powers between the branches of government, and his theory really works within the framework of the legislation of our country. This proportional delegation of powers between the Government, the President and the Federation Council, as well as the judiciary allows, first of all, preserving and correctly implementing the principle of the sovereignty of the people [5].

So, the state system of our country has gone a long way of modernization, so that we can legislatively find the optimal form of state structure.

\section{Bibliographic list}

1. "The Constitution of the Russian Federation" (adopted by popular vote on 12.12.1993 with amendments approved during the all-Russian vote on 01.07.2020) // Official Internet portal of legal information http://www.pravo.gov.ru, 04.07. 2020.

2. Russian Empire. Laws (1906). The highest approved Basic State Laws // Complete collection of laws of the Russian Empire. T. 26, department 1.1906

3. Locke, J. Two treatises on government / 1683. - 85-87 p. - Text: direct.

4. Montesquieu S. On the spirit of laws / 1748. - 146-159 p. - Text: direct.

5. Constant B. Principles of politics suitable for any government / 1815. 37- p. - Text: direct.

6. Speransky M.M. Introduction to the Code of State Laws / [Electronic resource] // URL: https://constitution.garant.ru/history/act1600-1918/3848894/

7. Muromtsev S.A. Draft Basic Law of the Russian Empire (1905) / [Electronic resource] URL: http: //museireform.rf/node/13705

8. Pestel P.I. Russian Truth or Preserved State Charter of the Great Russian People serving as a Testament for the Improvement of the State System of Russia and Containing a True Order for both the People and the Supreme Government (1823) / [Electronic resource] URL: http://www.rusconstitution.ru/library / constitution / articles / 9423 /

9. Basic State Law of the Russian Empire: Draft Russian Constitution, developed by a group of members of the Union of Liberation / [Electronic resource] // URL: https://allpravo.ru/library/doc313p/instrum3155/ item3157.html 
10. Popova A.V. Liberalism and neoliberalism in the legal dimension of Russia at the turn of the XIX-XX centuries. // Journal of Russian Law. 2011. No. 4 (172). P. 105-113.

11. Popova A.V. Neoliberal model of the state and social structure of Russia at the turn of the XIX-XX centuries: monograph. Moscow: Yurlitinform, 2012. 229 p.

12. Commentary on the Constitution of the Russian Federation / Komarov S.A., Drozdova A.M., Polishchuk N.I. and etc.; ed. S.A. Komarova. Mosocow: Yurayt, 2019. Ser. "Professional commentary" (3rd ed., Trans. And additional). 333 p.

For citation: Alekseeva A.A., Volobueva O.A. President as a special fourth branch of power in Russia: article // Legal thought. 2021. No. 4 (124). P. 18-23.

DOI: 10.47905 / MATGIP.2021.124.4.001

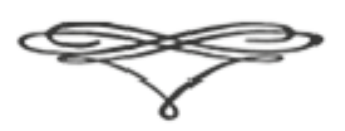




\title{
Фннаnсовая полнтнка, как наструмент овеСПЕчення устОЙчнвоГО развнтня регНона
}

\section{Г.В. Васниьев ${ }^{*}$}

\begin{abstract}
Аннотация. В статье рассматриваются вопросы реализации государственной политики Российской Федерации в области обеспечения устойчивого развития регионов России и концепции устойчивого развития в России, деятельность органов государственной вцасти в Российской Федерации в обцасти пцанирования социально-экономического развития Российской Федерации и регионов, региональная финансовая политика, как инструмент реализации социально-экономического развития региона.
\end{abstract}

Кмючевые слова. Устойчивое развитие, основы государственной политики регионального развития Российской Федерации, региональная фринансовая политика.

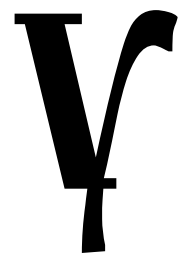

стойчивое развитие - процесс изменений, в котором эксплуатация природных ресурсов, направление инвестиций, ориентация научно-технического развития, развитие мичности и институциональные изменения согласованы друг с другом и укрепляют нынешний и будущий потенциал для удовлетворения человеческих потребностей и устремлений. Иными словами, под устойчивым развитием понимаются такие изменения, которые удовметворяют желания настоящего времени, но не ставят под угрозу способность будущих поколений удовлетворять свои собственные потребности.

Устойчивое развитие включает в себя два кАючевых взаимосвязанных понятия:

1) понятие потребностей, в т. ч. приоритетных (необходимых дия существования беднейших слоев насемения);

2) понятие ограничений (обусловленных состоянием технологии и организацией общества), накладываемых на способность окружающей среды удовметворять нынешние и будущие потребности чемовечества [10, с. 114].

* Васильев Георгий Владимирович, аспирант кафедры теории и истории государства и права Частного образовательного учреждения высшего образования "Юридический институт" (Санкт-Петербург), главный специалист-эксперт Юридического отдема Управления Федерального казначейства по г. Санкт-Петербургу. E-mail: ivanklugge@yandex.ru

Научный руководитель - Полишук Николай Иванович, профессор кафедры теории и истории государства и права Частного образовательного учреждения высшего образования "Юридический институт" (Санкт-Петербург), почетный работник высшего профессионального образования Российской Федерации, доктор юридических наук, профессор. E-mail: nik-polishchuk@yandex.ru 
Концепция устойчивого развития предпомагает бережное отношение к природе, как основополагающего фактора социально-экономического развития человечества, подчеркивается неразрывная связь между человеком и средой его обитания.

В то же время в науке отмечается, что дия достижения устойчивости развития современному обществу придется создать более эффективную систему принятия решений, учитывающую исторический опыт и поощряющую плюрализм. Именно осознание первостепенной важности решения социальных проблем явицось толчком к созданию Римского клуба и, в конечном счете, к возникновению самой концепции устойчивого развития. Без справедиивого распределения ресурсов и возможностей между всеми членами человеческого общества устойчивое развитие невозможно.

В России в феврале 1994 г. Президент РФ подписал Указ о переходе Российской Федерации на модель устойчивого развития, а соответствующая Концепция быма принята в 1996 г.

Переход к устойчивому развитию Российской Федерации в целом возможен только в том случае, если будет обеспечено устойчивое развитие всех ее регионов. Это предполагает формирование эффективной пространственной структуры экономики страны при соблюдении баланса интересов всех субъектов Российской Федерации, что предопределяет необходимость разработки и реализации программ перехода к устойчивому развитию дмя каждого региона, а также дальнейшей интеграции этих программ при разработке государственной политики в области устойчивого развития [10, с. 117-118]. Причем, экомогический аспект устойчивого развития Российской Федерации реализуется в блоке экологического законодательства.

Вместе с тем представцяется, что главным инструментом обеспечения устойчивого развития регионов Российской Федерации домжна явцяться региональная финансовая политика.

В науке даются следующие основные опредемения понятия "Региональная финансовая политика", а также ее характеристики, основные атрибуты, сущность.

Региональная финансовая политика - это совокупность целенаправменных мер региональных органов власти в области управцения финансами с целью создания фринансовой основы реализации социально-экономической политики региона [6, с. 139].

Региональная фринансовая политика - это самостоятельный, комплексный вид политики, проводимый региональными органами власти и управления. Комплексность данного вида политики заключается, в том, что она вкцючает в себя несколько относительно самостоятельных, но в то же самое время, взаимосвязанных видов политики. К видам политики, формирующим региональную финансовую политику, относятся: налоговая, бюджетная, инвестиционная, ценовая (тарифная) виды политики, а так же политика управления государственной собственностью.

Систематизация и обобщение подходов к разАичным определениям цели финансовой политики позволили сформулировать основную цель региональной финансовой политики как обеспечение стабильного устойчивого социально-экономического развития региона. В то же время в качестве 
поддерживающей цели (цели второго уровня) можно определить создание финансовой основы деятельности региональных органов власти для реализации задач и функций, возможенных на региональный уровень управцения $[7$, с. 5].

Региональная финансовая политика подчинена целям и задачам социально-экономической политики региона со стратегическим ориентиром на увеличение качества жизни населения, что требует определения критериев социально-экономического развития региональной многоуровневой системы, адекватно отражающих социально-экономические проблемы и приоритеты развития субъектов Российской Федерации на современном этапе $[8$, c. 56$]$.

Итак, в науке отмечается, что финансовая политика региона имеет своей целью обеспечение стабильного устойчивого социально-экономического развития региона, которое в свою очередь задает критерии формирования данной помитики.

В этой связи обратимся к Указу Президента РФ от 16.01.2017 № 13 «Об утверждении Основ государственной политики регионального развития Российской Федерации на период до 2025 года" [2]. Ознакомившись с данными Основами, мы приходим к выводу о том, что определение региональной финансовой политики, приведенное выше требует дополнения.

С учетом федеративного устройства Российской Федерации, необходимо отметить подпункты "г» и "д" пункта 5 Основ - принципы разграничения полномочий между федеральными органами государственной вцасти, органами государственной власти субъектов Российской Федерации и органами местного самоуправцения. А подпунктом "е» предполагается дифференцированный подход к реализации мер государственной поддержки регионов.

Пункт 6 названных Основ целями государственной политики регионального развития определяет обеспечение равных возможностей дмя реамизации установленных Конституцией Российской Федерации и федеральными законами экономических, политических и социальных прав граждан Российской Федерации на всей территории страны, повышение качества их жизни, обеспечение устойчивого экономического роста и научно-технологического развития регионов, повышение конкурентноспособности экономики Российской Федерации на мировых рынках на основе сбалансированного и устойчивого социально-экономического развития субъектов Российской Федерации и муниципальных образований, а также максимального привлечения населения $\mathrm{K}$ решению региональных и местных задач.

Согласно пункту 8 Основ результатами реализации государственной политики регионального развития должны стать:

а) сокращение разцичий в уровне и качестве жизни граждан Российской Федерации, проживающих в различных регионах, а также в городах и сельской местности;

б) сокращение различий в уровне социально-экономического развития регионов;

в) достижение необходимого уровня инфраструктурной обеспеченности всех населенных территорий Российской Федерации; 
г) дальнейшее развитие процесса урбанизации, в частности развитие крупных городских агломераций, как необходимое условие обеспечения экономического роста, технологического развития и повышения инвестиционной привлекательности и конкурентоспособности российской экономики на мировых рынках;

д) повышение уровня удовлетворенности населения деятельностью органов государственной вмасти субъектов Российской Федерации и органов местного самоуправцения [2].

Конечно, региональное развитие - это задача в первую очередь органов власти конкретного региона. Выше указано именно на разграничение полномочий органов вцасти - федерацьных, субъекта федерации и местных органов вцасти.

В то же время мы видим, исходя из сформулированных в Основах результатов реализации государственной политики регионального развития, что помимо достижения целей устойчивого стабильного социально-экономического развития регионов как таковых, предполагается также достижение результата социально-экономического развития в масштабах всей Российской Федерации - "сокращение разцичий в уровне социально-экономического развития регионов", "обеспечение экономического роста, технологического развития и повышения инвестиционной привлекательности и конкурентоспособности российской экономики на мировых рынках" [2].

Исходя из вышеизможенного, дополним опредемение понятия "Региональная финансовая политика" и сформулируем его так - комплекс мер, принимаемых органами государственной власти всех уровней, направленных на достижение целей социально-экономического развития региона, исходя из социально-экономического положения, существующего в конкретном регионе, дмя обеспечения стабимьного социально-экономического развития всей Российской Федерации, выравнивания социально-экономических показателей регионов страны, а также повышения экономических показателей Российской Федерации в целом.

С учетом того, что региональная финансовая политика направлена на обеспечение социально-экономического развития как региона, так и Российской Федерации в целом, нормативно данная деятельность органов государственной власти, регулируется, помимо собственно финансового законодательства, законодательством в области планирования социальноэкономического развития Российской Федерации, ее стратегического планирования развития.

Как уже отмечалось, использование природных ресурсов и их сбережение урегулированы блоком экологического законодательства. Так в обмасти планирования развития Российской Федерации действуют Основы государственной политики в области экологического развития России на период до 2030 года, утвержденные Президентом Российской Федерации от 30.04.2012 [3]. В пунктах 4 и 6 отмечается, что разработка данных Основ обусловлена необходимостью обеспечения экологической безопасности при модернизации экономики и в процессе инновационного развития, а государственная политика в области экологического развития Российской Федерации на период до 2030 года основывается, в том числе, на документах долгосрочного стратегического планирования [3]. 
Однако представляется, что именно региональная финансовая политика, как комплекс мер, проводимых на всех уровнях власти, имеющих цемью развитие социально-экономической среды, и (здесь именно это представляется самым главным критерием) подчиненных стратегическому планированию экономического развития Российской Федерации, и должна явмяться инструментом реализации концепции устойчивого развития в Российской Федерации, также и в экологическом аспекте. В связи с чем, представляется, что нормативное регулирование в данной отрасли должно не только взаимно друг друга учитывать, но стать единым механизмом реализации концепции устойчивого развития в Российской Федерации с тем, чтобы стратегическое планирование социально-экономического развития было увязано со сбережением природы, охраной окружающей среды, рациональным использованием природных ресурсов в целях устойчивого развития регионов России и Российской Федерации в целом.

На федеральном уровне власти меры по проведению региональной финансовой политики заключаются в издании федеральных законов, соответствующих подзаконных нормативных правовых актов, составмение и принятие государственных программ, разработка планов стратегического и иного развития Российской Федерации.

В соответствии с пунктами 3 и 4 Основ государственной политики регионального развития Российской Федерации на период до 2025 года установлено, что факторами и условиями регионального развития, оказывающими влияние на формирование и реализацию государственной политики регионального развития, явцяются:

а) федеративное устройство Российской Федерации и самостоятельное осуществление органами государственной власти субъектов Российской Федерации и органами местного самоуправцения своих полномочий;

б) размер территории Российской Федерации и протяженность ее государственной границы, количество приграничных государств;

в) географические, природно-кмиматические, демографические и социокультурные особенности регионов;

г) значительные разАичия в уровне социально-экономического развития регионов, неравномерное размещение производительных сиц и рассемение насемения на территории страны;

д) недостаточная инфраструктурная обеспеченность ряда регионов и городов, низкий уровень их экономического взаимодействия, высокая степень износа транспортной, энергетической и инженерной инфраструктуры.

Государственная политика регионального развития реализуется с учетом стратегических национальных приоритетов Российской Федерации, определенных в документах стратегического планирования, разработанных на федеральном уровне в рамках целеполагания, прогнозирования, планирования и программирования [2].

Положения статьи 32 Федерального закона от 28.06.2014 № 172-Ф3 "О стратегическом планировании в Российской Федерации" [1] устанавмивают, что порядок разработки и корректировки стратегии социальноэкономического развития субъекта Российской Федерации определяется 
законом или иным нормативным правовым актом субъекта Российской Федерации, в соответствии с законом субъекта Российской Федерации могут разрабатываться стратегии социально-экономического развития части территории субъекта Российской Федерации, социально-экономические усмовия в пределах которой требуют выделения отдельных направлений, приоритетов, целей и задач социально-экономического развития при разработке документов стратегического планирования субъекта Российской Федерации.

Пункты 3 и 3.1 Приказа Минэкономразвития России от 23.03.2017 № 132 «Об утверждении Методических рекомендаций по разработке и корректировке стратегии социально-экономического развития субъекта Российской Федерации и плана мероприятий по ее реализации" [4] при разработке и корректировке стратегии социально-экономического развития субъекта Российской Федерации рекомендуется определять конкурентные преимущества и экономическую специализацию субъекта Российской Федерации с учетом потенциала, проблем и перспектив развития основных отраслевых комплексов, представленных или предполагаемых к размещению на территории субъекта Российской Федерации, а также перспектив инновационного, инвестиционного, пространственного развития субъекта Российской Федерации, развития человеческого капитала с учетом приоритетов, целей и задач, обозначенных в документах стратегического планирования федерального уровня, а также учитывать:

- положения документов стратегического планирования Российской Федерации, разрабатываемых в рамках целеполагания (в частности, положения стратегии социально-экономического развития Российской Федерации, стратегии пространственного развития Российской Федерации, стратегии социально-экономического развития соответствующего макрорегиона, стратегии развития морской деятельности Российской Федерации и других), значимых для развития субъекта Российской Федерации, актов, указов и указаний Президента Российской Федерации по важнейшим вопросам государственной политики и социально-экономического развития;

- положения стратегий социально-экономического развития, иных документов стратегического планирования субъектов Российской Федерации, граничащих с данным субъектом Российской Федерации, результаты реализации стратегических документов субъекта Российской Федерации, действующих в предшествующем разработке Стратегии периоде;

- данные государственной и муниципальной статистики в качестве базового источника статистических данных [4].

На уровне органов власти субъекта Российской Федерации и местных органов власти финансовая политика региона реализуется в виде деятельности органов власти субъекта Российской Федерации и муниципальных образований в пределах их компетенции в вопросах законодательного регулирования, управления и организации финансовых потоков [9, с. 3].

Нормативное регулирование финансовой политики на региональном уровне заключается в составцении и принятии соответствующих планов и стратегий развития региона, принятия региональных государственных программ, бюджетное законодательство субъектов Российской Федераций и муниципальных образований. 
Выше мы уже указывали на подчиненность целей регионального развития целям развития Российской Федерации в целом. Деятельность органов власти субъекта Российской Федерации по разработке региональной политики (в том числе с учетом положения о роли развития региона в развитии Российской Федерации в целом) можно проследить на примере Областного закона Аенинградской области от 08.08.2016 № 76-оз "О Стратегии социально-экономического развития Аенинградской области до 2030 года и признании утратившим силу областного закона "О Концепции социальноэкономического развития Аенинградской области на период до 2025 года" (далее - $\Lambda \mathrm{O}$ "О стратегии С-ЭР $\Lambda \mathrm{O}$ ") [5].

В раздеме $2 \Lambda \mathrm{O} 3$ "О стратегии С-ЭР $\Lambda$ О" происходит определение приоритетов развития $\Lambda$ енинградской области. Здесь указывается, что страте-

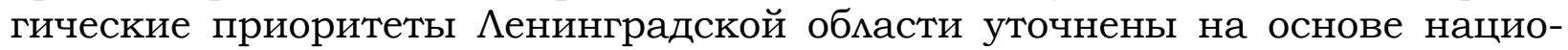
нальных целей и задач развития Российской Федерации и глобальных трендов, развитие которых в долгосрочной перспективе будет усиливаться

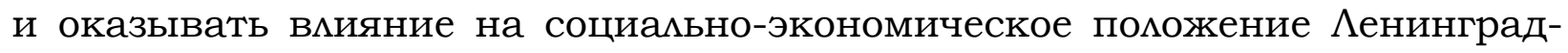
ской обцасти.

В перспективе до 2030 года будут развиваться глобальные тренды, связанные с последствиями демографического перехода и увеличением ожидаемой продомжительности здоровой жизни, нарастанием процессов урбанизации, появцением "умных городов", ростом международной миграции, усилением социального неравенства, изменением общественных и индивидуальных ценностей и образа жизни, распространением социальных инноваций, цифровизацией всех сфер деятельности, трансформацией системы образования.

На федеральном уровне определены 12 национальных проектов, которые объединены общей целью обеспечить прорывное научно-технологическое и социально-экономическое развитие России, повышение уровня жизни, создание условий и возможностей дмя самореализации и раскрытия таланта каждого человека [5].

Соответственно региональная финансовая политика - есть комплекс мер, направленных на обеспечение устойчивого социально-экономического развития региона России, в условиях и целях развития региона России, с учетом социально-экономического развития Российской Федерации. Данные меры принимаются как на федеральном, так и на региональном уровне. На федеральном уровне определяются основы стратегического планирования и социально-экономического развития Российской Федерации и регионов России.

На региональном уровне, органы государственной власти субъектов Российской Федерации и местные органы вмасти осуществляют - сбор и анамиз данных о социально-экономическом состоянии региона, нормативное регулирование в области социально-экономического развития региона, осуществляют реализацию мер в данной области, среди которых могут быть введение региональных налогов, установцение налоговых ставок дифференцированного характера, предоставление размичных видов мьгот, выдемение финансовой помощи в виде дотаций, субвенций, субсидий, инвестиционные меры, регулирование тарифов и другие, направленные, в том 
числе, на реализацию государственной политики в области социальноэкономического развития Российской Федерации.

В связи с чем, представцяется, что нормативное регулирование в данной отрасли должно не только взаимно друг друга учитывать, но стать единым механизмом реализации концепции устойчивого развития в Российской Федерации, с тем, чтобы стратегическое планирование социальноэкономического развития было увязано со сбережением природы, охраной окружающей среды, рациональным использованием природных ресурсов в целях устойчивого развития регионов России и Российской Федерации в целом.

\section{Бибциографический список}

1. Федеральный закон от 28.06.2014 № 172-Ф3 «О стратегическом планировании в Российской Федерации" // www.consultant.ru

2. Указ Президента Российской Федерации от 16.01.2017 № 13 «Об утверждении Основ государственной политики регионального развития Российской Федерации на период до 2025 года" / / www.consultant.ru

3. Основы государственной политики в области экологического развития Российской Федерации на период до 2030 года, утверждены Президентом Российской Федерации 30.04.2012) // www.consultant.ru

4. Приказ Минэкономразвития России от 23.03.2017 № 132 "Об утверждении Методических рекомендаций по разработке и корректировке стратегии социально-экономического развития субъекта Российской Федерации и плана мероприятий по ее реализации" (ред. от 06.04.2021) // www.consultant.ru

5. Областной закон Аенинградской области от 08.08.2016 № 76-оз "О Стратегии социально-экономического развития Аенинградской области до 2030 года и признании утратившим силу областного закона "О Концепции социальноэкономического развития Аенинградской обцасти на период до 2025 года" (ред. от 19.12.2019) // www.consultant.ru

6. Гусарова В.Н. Сущность региональной финансовой политики // Труды Псковского политехнического института. - 2008. - № 11.2. - С. 136-139.

7. Гусарова В.Н. Методологические аспекты формирования и реализации региональной финансовой политики // Вестник Псковского государственного университета. - Серия: Экономика. Право. Управление. - 2013. - № 3. C. $5-12$.

8. Гринкевич А.С., Аазичева Е.А. Современная региональная финансовая политика: содержание и принципы формирования // Вестник Томского государственного университета. - 2009. - № 3(7). - С 55-60.

9. Митина И.А., Челышева Э.А. Финансовая политика региона и особенности ее реализации (на примере Ростовской области) // Вестник Евразийской науки. 2018. № 1. [Эмектронный ресурс]. Режим доступа: https://esj.today/PDF/ 51ECVN118.pdf (дата обращения 24.09.2021).

10. Аевина Е.И. Понятие "Устойчивое развитие». Основные положения концепции // Вестник ТГУ. - 2009. - № 11(79) - С. 113-119.

Дия цитирования: Васильев Г.В. Финансовая политика, как инструмент обеспечения устойчивого развития региона: статья // Юридическая мысль. - 2021.- № 4 (124). C. 24-31.

DOI: $10.47905 /$ MATGIP.2021.124.4.002 


\title{
Financial policy as a tool ensuring sustainable development of the region
}

\section{Georgy V. Vasiliev*}

\begin{abstract}
Annotation. The article discusses the implementation of the state policy of the Russian Federation in the field of ensuring sustainable development of the regions of Russia and the concept of sustainable development in Russia, the activities of public authorities in the Russian Federation in the field of planning the socio-economic development of the Russian Federation and regions, regional financial policy as a tool for implementing social -economic development of the region.
\end{abstract}

Keywords: Sustainable development, foundations of state policy of regional development of the Russian Federation, regional financial policy.

Sustainable development is a process of change in which the exploitation of natural resources, the direction of investment, the orientation of scientific and technological development, personal development and institutional change are aligned with each other and strengthen the current and future capacities to meet human needs and aspirations. In other words, sustainable development refers to those changes that satisfy the desires of the present, but do not jeopardize the ability of future generations to meet their own needs.

Sustainable development includes two key interrelated concepts:

1) the concept of needs, including priority ones (necessary for the existence of the poorest segments of the population);

2) the concept of restrictions (due to the state of technology and organization of society) imposed on the ability of the environment to meet the current and future needs of mankind [10, p. 114].

The concept of sustainable development assumes respect for nature, as a fundamental factor in the socio-economic development of mankind, emphasizes the inextricable link between man and his environment.

At the same time, science notes that in order to achieve sustainable development, modern society will have to create a more effective decision-making system that takes into account historical experience and encourages pluralism. It was the realization of the paramount importance of solving social problems that prompted the creation of the Club of Rome and, ultimately, the emergence of the very concept of sustainable development. Sustainable development is impossible without equitable distribution of resources and opportunities among all members of human society.

In Russia, in February 1994, the President of the Russian Federation signed a decree on the transition of the Russian Federation to a sustainable development model, and the corresponding Concept was adopted in 1996.

* Vasiliev Georgy Vladimirovich, post-graduate student of the Department of Theory and History of State and Law of the Private Educational Institution of Higher Education "Legal Institute" (St. Petersburg), chief specialist-expert of the Legal Department of the Federal Treasury Department in St. Petersburg. E-mail: ivanklugge@yandex.ru

Academic Supervisor - Nikolai Ivanovich Polishchuk, Professor of the Department of Theory and History of State and Law of the Private Educational Institution of Higher Education "Legal Institute" (St. Petersburg), Honorary Worker of Higher Professional Education of the Russian Federation, Doctor of Law, Professor. E-mail: nik-polishchuk@yandex.ru 
The transition to sustainable development of the Russian Federation as a whole is possible only if sustainable development of all its regions is ensured. This presupposes the formation of an effective spatial structure of the country's economy while maintaining a balance of interests of all constituent entities of the Russian Federation, which predetermines the need for the development and implementation of programs for the transition to sustainable development for each region, as well as further integration of these programs in the development of state policy in the field of sustainable development [10, p. 117-118]. Moreover, the environmental aspect of sustainable development of the Russian Federation is implemented in the block of environmental legislation.

At the same time, it seems that the main instrument for ensuring sustainable development of the regions of the Russian Federation should be the regional financial policy.

In science, the following basic definitions of the concept of "Regional financial policy" are given, as well as its characteristics, main attributes, essence.

Regional financial policy is a set of targeted measures of regional authorities in the field of financial management in order to create a financial basis for the implementation of the socio-economic policy of the region [6, p. 139].

Regional financial policy is an independent, complex type of policy pursued by regional authorities and administration. The complexity of this type of policy lies in the fact that it includes several relatively independent, but at the same time, interrelated types of policy. The types of policies that form the regional financial policy include: tax, budget, investment, price (tariff) types of policy, as well as the policy of managing state property.

The systematization and generalization of approaches to various definitions of the goal of financial policy made it possible to formulate the main goal of the regional financial policy as ensuring stable sustainable socio-economic development of the region. At the same time, the creation of a financial basis for the activities of regional authorities for the implementation of tasks and functions assigned to the regional level of government can be defined as a supporting goal (goals of the second level) [7, p. 5].

Regional financial policy is subordinated to the goals and objectives of the socio-economic policy of the region with a strategic focus on increasing the quality of life of the population, which requires the definition of criteria for the socio-economic development of a regional multi-level system that adequately reflects the socio-economic problems and development priorities of the constituent entities of the Russian Federation at the present stage [8, p. 56].

So, in science it is noted that the financial policy of the region is aimed at ensuring stable sustainable socio-economic development of the region, which in turn sets the criteria for the formation of this policy.

In this regard, let us refer to the Decree of the President of the Russian Federation of January 16, 2017 No. 13 "On approval of the Fundamentals of State Policy for Regional Development of the Russian Federation for the Period until 2025" [2]. After reviewing these Fundamentals, we come to the conclusion that the definition of regional financial policy given above needs to be supplemented.

Taking into account the federal structure of the Russian Federation, it is necessary to note subparagraphs " $d$ " and "e" of paragraph 5 of the Fundamen- 
tals - the principles of delimitation of powers between federal government bodies, government bodies of the constituent entities of the Russian Federation and local government bodies. And subparagraph "e" assumes a differentiated approach to the implementation of measures of state support for the regions.

Clause 6 of the named Fundamentals as the goals of the state policy of regional development determines the provision of equal opportunities for the implementation of the economic, political and social rights of citizens of the Russian Federation established by the Constitution of the Russian Federation and federal laws throughout the country, improving their quality of life, ensuring sustainable economic growth and scientific research. technological development of regions, increasing the competitiveness of the economy of the Russian Federation in world markets on the basis of a balanced and sustainable socio-economic development of the constituent entities of the Russian Federation and municipalities, as well as maximum involvement of the population in solving regional and local problems.

According to paragraph 8 of the Fundamentals, the results of the implementation of the state policy of regional development should be:

a) reducing differences in the level and quality of life of citizens of the Russian Federation living in different regions, as well as in cities and rural areas;

b) reduction of differences in the level of socio-economic development of regions;

c) achieving the required level of infrastructure provision for all inhabited territories of the Russian Federation;

d) further development of the urbanization process, in particular the development of large urban agglomerations, as a necessary condition for ensuring economic growth, technological development and increasing the investment attractiveness and competitiveness of the Russian economy in world markets;

e) increasing the level of satisfaction of the population with the activities of state authorities of the constituent entities of the Russian Federation and local authorities [2].

Of course, regional development is primarily a task for the authorities of a particular region. Above it is indicated precisely on the delineation of powers of the authorities - federal, subject of the federation and local authorities.

At the same time, we see, based on the results of the implementation of the state policy of regional development formulated in the Fundamentals of the results of the implementation of the state policy of regional development, that in addition to achieving the goals of sustainable stable socio-economic development of regions as such, it is also expected to achieve the result of socioeconomic development throughout the Russian Federation - "reducing differences in the level of socio-economic development of regions", "ensuring economic growth, technological development and increasing investment attractiveness and competitiveness of the Russian economy in world markets" [2].

Based on the foregoing, we will supplement the definition of the concept of "Regional financial policy" and formulate it as follows - a set of measures taken by public authorities at all levels, aimed at achieving the goals of socioeconomic development of the region, based on the socio-economic situation existing in in a specific region, to ensure stable socio-economic development of 
the entire Russian Federation, equalize the socio-economic indicators of the regions of the country, as well as increase the economic indicators of the Russian Federation as a whole.

Taking into account the fact that the regional financial policy is aimed at ensuring the socio-economic development of both the region and the Russian Federation as a whole, normatively, this activity of public authorities is regulated, in addition to the financial legislation itself, by the legislation in the field of planning the socio-economic development of the Russian Federation, its strategic development planning.

As already noted, the use of natural resources and their conservation are regulated by a block of environmental legislation. So in the field of planning the development of the Russian Federation, the Fundamentals of State Policy in the Field of Environmental Development of Russia for the period up to 2030, approved by the President of the Russian Federation on April 30, 2012 [3], are in effect. In paragraphs 4 and 6 , it is noted that the development of these Fundamentals is due to the need to ensure environmental safety during the modernization of the economy and in the process of innovative development, and the state policy in the field of environmental development of the Russian Federation for the period up to 2030 is based, among other things, on documents of long-term strategic planning [3].

However, it seems that it is the regional financial policy, as a set of measures carried out at all levels of government, with the aim of developing the socio-economic environment, and (here this is the most important criterion) subordinate to the strategic planning of economic development Of the Russian Federation, and should be a tool for the implementation of the concept of sustainable development in the Russian Federation, also in the environmental aspect. In this connection, it seems that normative regulation in this industry should not only take into account each other, but become a single mechanism for the implementation of the concept of sustainable development in the Russian Federation so that strategic planning of socio-economic development is linked to saving nature, environmental protection, rational use of natural resources for the sustainable development of the regions of Russia and the Russian Federation as a whole.

At the federal level of government, measures for the implementation of regional financial policy consist in the publication of federal laws, the corresponding by-laws, the preparation and adoption of state programs, the development of plans for the strategic and other development of the Russian Federation.

In accordance with clauses 3 and 4 of the Fundamentals of State Policy for Regional Development of the Russian Federation for the period up to 2025, it is established that the factors and conditions of regional development that influence the formation and implementation of the state policy of regional development are:

a) the federal structure of the Russian Federation and the independent exercise of their powers by the state authorities of the constituent entities of the Russian Federation and local self-government bodies;

b) the size of the territory of the Russian Federation and the length of its state border, the number of border states; 
c) geographical, climatic, demographic and socio-cultural characteristics of the regions;

d) significant differences in the level of socio-economic development of regions, uneven distribution of productive forces and dispersal of the population on the territory of the country;

e) insufficient infrastructural provision of a number of regions and cities, a low level of their economic interaction, a high degree of wear and tear of the transport, energy and engineering infrastructure.

The state policy of regional development is implemented taking into account the strategic national priorities of the Russian Federation, defined in the strategic planning documents developed at the federal level within the framework of goal-setting, forecasting, planning and programming [2].

The provisions of Article 32 of the Federal Law of June 28, 2014 No. 172FZ "On Strategic Planning in the Russian Federation" [1] establish that the procedure for developing and adjusting the strategy of socio-economic development of a constituent entity of the Russian Federation is determined by a law or other regulatory legal act of a constituent entity of the Russian Federation. Federation, in accordance with the law of a constituent entity of the Russian Federation, strategies for the socio-economic development of a part of the territory of a constituent entity of the Russian Federation can be developed, the socioeconomic conditions within which require the allocation of certain areas, priorities, goals and objectives of socio-economic development in the development of documents strategic planning of the constituent entity of the Russian Federation.

Clauses 3 and 3.1 of the Order of the Ministry of Economic Development of Russia dated 03.23.2017 No. 132 "On approval of Methodological recommendations for the development and adjustment of the strategy of socioeconomic development of a constituent entity of the Russian Federation and an action plan for its implementation" [4] when developing and adjusting strategies of socio-economic development of the constituent entity of the Russian Federation are recommended to determine the competitive advantages and economic specialization of the constituent entity of the Russian Federation, taking into account the potential, problems and prospects for the development of the main industry complexes, presented or expected to be located on the territory of the constituent entity of the Russian Federation, as well as the prospects for innovation, investment, spatial development of the constituent entity of the Russian Federation, development of human capital, taking into account the priorities, goals and objectives outlined in the strategic planning documents of the federal level, and also take into account:

- the provisions of the strategic planning documents of the Russian Federation, developed within the framework of goal-setting (in particular, the provisions of the strategy for the socio-economic development of the Russian Federation, the strategy for the spatial development of the Russian Federation, the strategy for the socio-economic development of the corresponding macroregion, the strategy for the development of the sea activities of the Russian Federation and others) significant for the development of a constituent entity of the Russian Federation, acts, decrees and instructions of the President of the Russian Federation on the most important issues of state policy and socioeconomic development; 
- provisions of the strategies of socio-economic development, other strategic planning documents of the constituent entities of the Russian Federation bordering on this constituent entity of the Russian Federation, the results of the implementation of strategic documents of the constituent entity of the Russian Federation in force in the period preceding the development of the Strategy; data [4].

- data of state and municipal statistics as a basic source of statistical

At the level of the authorities of the constituent entity of the Russian Federation and local authorities, the financial policy of the region is implemented in the form of the activities of the authorities of the constituent entity of the Russian Federation and municipalities within their competence in matters of legislative regulation, management and organization of financial flows [9, p. 3].

Regulatory regulation of financial policy at the regional level consists in the preparation and adoption of appropriate plans and strategies for the development of the region, the adoption of regional state programs, budgetary legislation of the constituent entities of the Russian Federation and municipalities.

Above, we have already indicated the subordination of the goals of regional development to the goals of the development of the Russian Federation as a whole. The activities of the authorities of the constituent entity of the Russian Federation on the development of regional policy (including taking into account the provisions on the role of the development of the region in the development of the Russian Federation as a whole) can be traced on the example of the Regional Law of the Leningrad Region of 08.08.2016 No. 76-oz "On the Strategy of Social and Economic Development of the Leningrad Region until 2030 and the recognition as invalid of the Regional Law" On the Concept of Social and Economic Development of the Leningrad Region for the Period until 2025 "(hereinafter referred to as the LPO "On the Strategy of the S-ER LO") [5].

In section 2 of the LPZ "On the strategy of the S-ER LP", the priorities for the development of the Leningrad region are determined. It is indicated here that the strategic priorities of the Leningrad region have been clarified on the basis of the national goals and objectives of the development of the Russian Federation and global trends, the development of which in the long term will intensify and affect the socio-economic situation of the Leningrad region.

In the future, until 2030, global trends will develop associated with the consequences of the demographic transition and an increase in healthy life expectancy, an increase in urbanization processes, the emergence of "smart cities", an increase in international migration, an increase in social inequality, a change in social and individual values and lifestyle, the spread of social innovation, the digitalization of all spheres of activity, the transformation of the education system.

At the federal level, 12 national projects have been identified, which are united by the common goal of ensuring a breakthrough scientific, technological and socio-economic development of Russia, raising the standard of living, creating conditions and opportunities for self-realization and disclosing the talent of each person [5].

Accordingly, the regional financial policy is a set of measures aimed at ensuring sustainable socio-economic development of the Russian region, in the conditions and purposes of the development of the Russian region, taking into account the socio-economic development of the Russian Federation. 
These measures are being taken both at the federal and regional levels. At the federal level, the foundations of strategic planning and socio-economic development of the Russian Federation and regions of Russia are determined.

At the regional level, the state authorities of the constituent entities of the Russian Federation and local authorities carry out - collection and analysis of data on the socio-economic state of the region, normative regulation in the field of socio-economic development of the region, carry out the implementation of measures in this area, including the introduction of regional taxes, the establishment of tax rates of a differentiated nature, the provision of various types of benefits, the allocation of financial assistance in the form of grants, subventions, subsidies, investment measures, regulation of tariffs and others, aimed, inter alia, at the implementation of state policy in the field of socioeconomic development of the Russian Federation ...

In this connection, it seems that normative regulation in this industry should not only take into account each other, but become a unified mechanism for the implementation of the concept of sustainable development in the Russian Federation, so that strategic planning of socio-economic development is linked to the conservation of nature, environmental protection, rational use of natural resources for the sustainable development of the regions of Russia and the Russian Federation as a whole.

\section{Bibliographic list}

1. Federal Law of June 28, 2014 No. 172-FZ "On Strategic Planning in the Russian Federation" // www.consultant.ru

2. Decree of the President of the Russian Federation of January 16, 2017 No. 13 "On Approval of the Fundamentals of State Policy for Regional Development of the Russian Federation for the Period up to 2025" // www.consultant.ru

3. Fundamentals of state policy in the field of environmental development of the Russian Federation for the period up to 2030, approved by the President of the Russian Federation on April 30, 2012) // www.consultant.ru

4. Order of the Ministry of Economic Development of the Russian Federation of 23.03.2017 No. 132 "On approval of Methodological recommendations for the development and adjustment of the strategy of socio-economic development of the constituent entity of the Russian Federation and an action plan for its implementation" (as amended on 06/04/2021) // www.consultant .ru

5. Regional law of the Leningrad region of 08.08.2016 No. 76-oz "On the Strategy of socio-economic development of the Leningrad region until 2030 and the recognition as invalid of the regional law "On the Concept of socio-economic development of the Leningrad region for the period until 2025" (ed. from 19.12.2019) // www.consultant.ru

6. Gusarova V.N. The essence of regional financial policy // Proceedings of the Pskov Polytechnic Institute. 2008. No. 11.2. P. 136-139.

7. Gusarova V.N. Methodological aspects of the formation and implementation of regional financial policy // Bulletin of the Pskov State University. Series: Economics. Right. Control. 2013. No. 3. P. 5-12.

8. Grinkevich L.S., Lazichev E.A. Modern regional financial policy: content and principles of formation // Bulletin of the Tomsk State University. 2009. No. 3 (7). P. 55-60.

9. Mitina I.A., Chelysheva E.A. Financial policy of the region and features of its implementation (on the example of the Rostov region) // Bulletin of Eurasian Science. 
2018. No. 1. [Electronic resource]. Access mode: https://esj.today/PDF/ 51ECVN118. pdf (date of access 09.24.2021).

10. Levina E.I. The concept of "Sustainable development". The main provisions of the concept // Vestnik TSU. 2009. No. 11 (79). P. 113-119.

For citation: Vasiliev G.V. Financial policy as a tool for ensuring sustainable development of the region: article // Legal thought. 2021. No. 4 (124). P. 32-39.

DOI: 10.47905 / MATGIP.2021.124.4.002

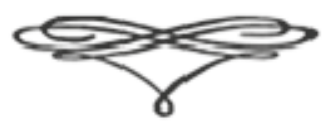




\title{
Устойчнвое развнтне: прОБАЕМЫ н перспекТнВЫ
}

\section{B.đ. ГАазков* Ф.И. Певченков ${ }^{* *}$}

\begin{abstract}
Аннотация. В статье анализируется концепция устойчивого развития как вполне естественный могический переход от экологизации научных знаний и социально-экономического развития к вопросам ограниченности природных ресурсов, а также загрязнения природной среды, которая является основой жизни,

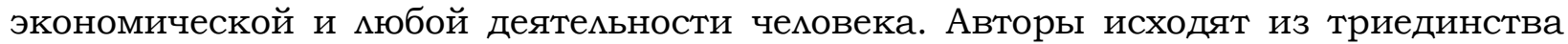
основных оценочных категорий определяющих устойчивое развитие: экономический рост, социальная ответственность и экологический баланс.
\end{abstract}

Кмючевые слова: устойчивое развитие, экология, экономический рост, государственная идеология,

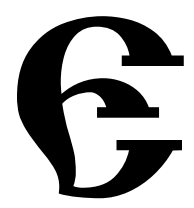

сли вспомнить крылатое, абсолютно точное и предельно емкое выражение Э. Дюркгейма, что научному исследованию должны подвергаться не понятия о социальной реальности, а она сама непосредственно, то сразу же возникают вопросы относительно введения в научный оборот понятия "устойчивое развитие" и трех его основных составляющих: экономический рост, социальная ответственность и экологический баланс.

Bo-nервых, сразу видно, что это крайне оценочные категории.

Bo-вторых, надо выяснить есть $\Lambda$ и за этими понятиями что-то реально существующее или авторы этой "модной" сегодня концепции произвоцьно выдумали опредеменный категориальный аппарат и пытаются под него подвести объективную действительность, хотя все прекрасно понимают, что все домжно быть наоборот.

$B$-третьих, мюбая научная теория и понятийный аппарат не возникают сами по себе. Здесь также важно знать, кто ее заказчики, исполнители, носители и какие они преследуют цели. Правовая теория не существует вне или без социально-экономических, политических, культурных и других процессов и явлений, а есть их юридическая форма закрепления и выражения.

$B$-четвертых, важен не только экономический рост, а его направленность, это только средство достижения цели, а какова она сама, за счет кого и чего достигается? Экономический рост сопровождается повышением

" Глазков Виктор Анатольевич, ректор ГУ $\Lambda$ НР "Ауганская академия внутренних дел имени Э.А. Дидоренко", кандидат юридических наук, доцент.

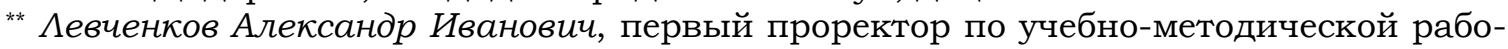
те и международным связям ГУ $\Lambda$ "Ауганская академия внутренних дел имени Э.А. Дидоренко", доктор юридических наук, профессор. 
материального состояния всего народа, среднего класса, олигархов? Как протекает этот процесс, его интенсивность, временные рамки, издержки и т.п. Может быть, экономический рост выражается в развитии отдемьных, наиболее важных отраслях народного хозяйства: космос, электроника, обороноспособность страны, сельское хозяйство, медицина и т.д. Сопровождается $\Lambda$ он большими потерями в экологической сфере? Постоянен он или эпизодичен? и т.д.?

$B$-nятых, за миберально-утопическим понятием "социальная ответственность" в условиях постсоветского варианта "обществе потребления" скрывается неудачная попытка оградить олигархические кланы от их реального, действенного масштабного участия в решении социально-экономических и политических вопросов в пользу большинства населения страны, хотя бы путем введения прогрессивного налогообложения, что характерно и считается обычной демократической процедурой в той же Франции, Финляндии, Норвегии и других социально ориентированных государствах.

Естественно, что эти процессы домжны найти свое выражение и закрепление в политической и правовой идеологии, действующем законодательстве, нравственных установках культивируемых в обществе и т.п.

И если начинать движение в этом направлении, то необходимо это демать с реформирования ст. 13 Конституции Российской Федерации [1]. Слава Богу, то, о чем мы писали несколько мет назад уже сделано - в ходе конституционной реформы, инициированной В.В. Путиным, часть 4 статья 15 Конституции Российской Федерации, которая была основой дмя вмешательства во внутренние дела современной России со стороны комлективного Запада, получима иное видение [1].

Теперь настала очередь то же самое сделать и с тринадцатой статьей Основного Закона страны. Идеологический плюрализм необходим на стадии выработки господствующей государственной идеологии, но не более.

Сегодня всем стало ясным и понятным, что в государствах переходного типа, к которым относится и РФ, отсутствует четкая, единая государственная идеология, в том числе и правовая. В существующих на властных программных установках, зафиксированы интересы не большинства общества (народе), а национальных элит, часто являющимися носителями и пропагандистами чуждых основной массе населения идей и так называемых западных ценностей. Запад - это доминирование индивидуацьных ценностей над комлективными и разобщенность социума по различным критериям. В первую очередь, материальным для славянского (советского) менталитета бымо характерным доминирование комлективных ценностей и солидарность. Сегодня по этим правилам живет, развивается, становится мидирующей в мире державой тысячелетний Китай.

Сегодня государственная идеология России, с одной стороны, предстает в виде трудно сочетаемого целого, в которое входят мучшие традиции советского патриотизма, в основе которого межат события Великой Отечественной войны, героизм советского народа и великая Победа. Второй составной частью существующей государственной идеологии являются подходы и ценности "общества потребления", третьей составной - российское православие. Всем понятно, что, по сути, мы видим попытку свести в единое целое 
вещи абсолютно несовместимые и несводимые. Естественно, что такая идеомогическая конструкция будет шаткой, мало эффективной и недолговечной.

С тметворным влиянием на все стороны жизнедеятельности человека "общества потребления" все понятно, дия того, чтобы воспитать новое молодое поколение в духе патриотизма, Аюбви к Родине и которое не будет исповедовать и слепо следовать основным западным ценностям - "сначала думай о себе, а потом о Родине", "деньги не пахнут" и т.д., на это уйдут десятиметия и то при условии, если молодежи будет предоставлено заслуживающее внимание альтернатива другого мировосприятия и другие ценности.

Включением в механизм государства Церкви, можно оправдать только текущим неблагоприятным дмя действующей вцасти обстоятельствами, ее неустойчивостью и необходимостью в срочной поддержке со стороны всех общественных институтов, в том числе и такого, и может рассматриваться как временная мера, ибо устойчивые и тесные материальные связи Церкви с социумом и как следствие зависимость от него, как показывает далекая и близкая к нам история, подрывают ее авторитет в миру как высшего морального авторитета.

Использование героического прошлого нашего народа (ВОВ 1941-1945) также имеет свои временные и экстремальные пределы. Не менее героические события Отечественной войны 1812 года кажутся сегодня совсем дамекими и не всегда понятными для современной молодежи. Да, наверное, и мысли о необходимости броситься со связкой гранат под фашистский

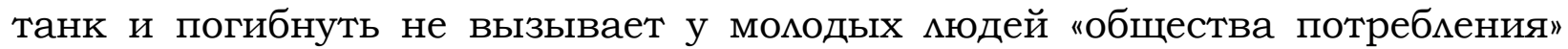
большего энтузиазма. Хотя события в Сирии показали нам, а также всему миру, что здесь не все еще потеряно - возрождение высокой духовности и проявцений героизма у русского народа еще возможно.

Но если быть честными до конца, то, наверное, также следует сказать, что несмотря на призывы к тому, что в РФ не должно существовать государственной или обязательной идеологии (ст. 13 Конституции РФ), тем не менее она есть, но эта идеология в конечном счете "общества потребления", от которой мы должны избавиться и как можно быстрее. Несмотря на заявленное идеологическое многообразие, она явцяется господствующей и жестко реагирует не только на попытки ее реформировать и перенацелить, но даже на попытки вывести из "тени", показать ее истинное мицо (учредителей и носитемей).

Идеология "общества потребления" родимась в конце 80-х годов прошлого века и заявила о себе в полный голос в августе 1993 года пушечными выстрелами по зданию Верховного Совета Российской Федерации. Формировалась она во властных кабинетах Белого Дома США, а затем через и с помощью "говорящих голов" от бизнеса, науки, культуры (З. Бжезинский, Г. Киссинджер, Дж. Сорес, А. Яковлев, А. Сомженицын, О. Гончар и др.) привносилась в сердца и умы наших граждан как единственно верное, надежное и эффективное направление дальнейшего развития постсоветского пространства. Таким образом, по словам Валентина Распутина, в это время произошло жертвоприношение советского народа в угоду Запада.

И. Н. Барциц высказался по этому поводу достаточно четко, заявив, что восприняв западную идею "потребления", российское общество не мо- 
жет этим удовлетвориться, оно продолжает нуждаться в иной государственной идее, справедливости, во всех ее проявлениях. В первую очередь, в экономической, политической и правовой сферах [2].

Что касается очередной утопии относительно возможности установмения и поддержки в современных условиях "экологического баланса", то можно сказать следующее.

Экологическая проблема возникла и сегодня существует как специфическая социальная проблема с появлением homo sapiens. ГАавное в противоречии между обществом и природой состоит в том, что человек - сын природы - все больше отделяется от нее (и этот процесс стал необратимым), противостоит и уничтожает ее.

На производственной деятельности человека (масштаб и степень эксплуатации природной среды) основываются как единство, равновесие и гармония, так и конфронтация, и дисгармония между обществом и природой. Эти взаимоотношения фиксируют различные стороны и стадии их развития. Именно в зависимости от характера и развития мировой (или отдельного государства, региона) экономики складываются та или иная ситуация, то или иное положение и та или иная структура во взаимоотношениях между обществом и природой. В этой связи также следует отметить, что указанные выше составные - единство, равновесие, дисгармония, конфронтация - характеризуют разные стороны зрелости и развития этого фундаментального общественного противоречия.

Экологическая проблема, взятая в ее генезисе, есть не что иное, как отражение истории взаимоотношения человека и природы, которая в своем развитии воспроизводит этапы нарастающих противоречий между обществом и природой.

Еще первая промышленная революция положила начало неконтролируемой эксплуатации земных богатств и массовому загрязнению среды обитания чемовека отходами новой производственной деятельности.

Эта неконтролируемая эксплуатация земных богатств и загрязнение окружающей среды стократно выросли в современных условиях. И все это делалось и делается с единственной целью - получение сверхприбыли, цели, не соотносимой ни с ближайшими, ни с более отдаленными отрицательными последствиями такой деятельности. Сейчас все это приводит к нарушению равновесия и к конфронтации общества с природой, к антагонизму и противоречию между ними, угрожает перерасти в глобальный кризис, в препятствии дия дальнейшего нормального существования человечества.

Сегодня в экологической сфере наблюдаются две основные господствующие тенденции. В основе первой межат интенсивный одновременный рост материальной и духовной культуры человечества, что дает повод демать оптимистические прогнозы на счет нашей дальнейшей цивилизационной перспективы.

В основе другой наблюдается четкая тенденция, которая характеризуется разцичными факторами невиданной до сих пор антропогенной нагрузки на природу - ускоренной, хищнической ее эксплуатации, уменьшением и исчерпыванием природных ресурсов, что сопровождается неограниченным и неконтролируемым загрязнением окружающей среды. Эта тенден- 
ция порождает оправданный пессимизм относительно будущего развития чемовеческой цивимизации.

В основе этого пессимизма цежит интенсивное и нерациональное использование земных богатств, многократное увеличение количества промышиенных отходов, быстрое загрязнение биосферы и ее компонентов. Имеются также много признаков, которые свидетельствуют о том, что биомогическая и социальная природа человека стоит сегодня перед серьезнейшими вызовами и испытаниями - COVID-19, который может привести к многомимлионным жертвам, явцяется этому прямым доказательством.

Несомненно одно, сегодня сложилась негативная ситуация дисгармонии и конфронтации человека и природы и можно с полным основанием говорить о наличии двух уровней противоречий социально-экономического и политико-экономического и культурного характера в современном мире. А именно - противоречия на уровне объекта - общественной реальности и противоречия на уровне, субъективного фактора, взятого в разАичных сферах своего проявмения.

Суть объективных причин состоит в том, что существующий сегодня уровень научного познания происходящих в мире процессов все еще не может обеспечить радикального решения основного вопроса - о допустимой мере человеческого вмешательства в природу с тем, чтобы не разрушать ее гармонию и единство с обществом.

Субъективные причины заключаются в том, что в современном социуме до сих пор (на всех его ступенях) еще не сформировалось экологическое сознание, экологическое мышление (от мидеров государств, национальных элит и до простых граждан) и что гораздо важнее (до сих пор отсутствуют) конструктивные и согласованные действия в этой области всего мирового сообщества. Хотя в последнее время в связи с резким изменением климата декмаративные заявления и риторика в этом направлении усиливается.

Рассмотренные здесь противоречия являются в современных условиях, как считают некоторые специалисты, основными противоречиями между чемовеком и природой. Ситуация в этом плане кардинально усугубляется и тем, что экология стала, с одной стороны, действенным средством решения политических проблем, а с другой стороны, по сути, "заложницей" политики.

Принципы политической целесообразности и экономической выгоды становятся, к сожалению, основными и определяют конкретные подходы к решению экологических проблем.

Яркий пример этому, события вокруг "Северного потока" - санкции против него. Борьба государств и национальных элит за или против его постройки и введения в эксплуатацию - предельно политизировано. Использование экологических проблем во внутрипартийной борьбе особенно четко проявились во время выборов канциера ФРГ и непосредственно позиции "зеленых" в этих вопросах. То есть, экология стала объектом большой мировой политики и средством достижения политических целей за ее счет.

В таких условиях о равновесии трех составных "устойчивого равновесия" вообще речь идти не может. Мир сегодня предемьно разбалансирован и не в состоянии быть, априори, устойчивым и консолидированным. Каждое государство в условиях системного мирового кризиса пытается выжи- 
вать и ресурсов Земли.

Отфрид Гьофе прямо указывает на причину такого отношения человека к природе: "То, что Аюди приносят вред необходимой дмя их выживания окружающей среде, свидетельствует об их глупости и непосредственно о близорукости и отсутствии понимания экологических последствий. Причины этого кроются и в структурных недостатках рынка: пока прибылью акт деятельности приводящей к загрязнению окружающей среды, пользуются отдельные индивиды, а причиненный ущерб достается всему обществу, до тех пор эти загрязнения тяжело преодолеть" [3, с. 385].

Также при исследовании экологических проблем следует обратить внимание на отсутствие у населения многих стран, в том числе и постсоветских, развитой экологической культуры и это, к сожалению, касается как рядовых граждан, так и чиновников разных уровней, в том числе и тех, которым это прописано их должностными полномочиями.

Ресурсы Земли не безграничны, питьевой воды становится все меньше, количества месных насаждений и даже "безбрежная" сибирская тайга так же, как и меса Амазонки, сокращаются катастрофическим образом. Мировые запасы нефти и газа, как наиболее востребованные во всех странах энергетические ресурсы, также подходят сегодня к концу. Все это говорит о необходимости поиска новых комплексных подходов к решению экологических проблем всем мировым сообществам, однако, в угоду ежеминутным интересам, особенно мидирующими государствами, это правило часто не соблюдается.

Естественно, в такой ситуации говорить о "равновесии" трех основных составцяющих "устойчивое развитие", не имеет смысла. Ответ на этот вопрос межит на поверхности: экономический рост в государствах переходного типа (нестабильных социумах) неизбежно выступает в противовес с экологической средой, так как и осуществляется за счет ее эксплуатаций и снижения социальной функции государства и увцечения алчности транснациональных корпораций.

У человеческой цивилизации все меньше времени остается на решение этой, безусловно, важнейшей проблемы, с которой непосредственно связано ее настоящее и будущее.

\section{Бибинографический список}

1. "Конституция Российской Федерации" (принята всенародным голосованием 12.12.1993 с изменениями, одобренными в ходе общероссийского голосования 01.07.2020) // www.consultant.ru

2. Барииц И. Н. Доктрина конституционного патриотизма: европейский вызов и российская перспектива // Государство и право. - 2014. - С. 5-17. $436 \mathrm{c}$.

3. Omфpid Гьофре. Демократія в епоху глобалізації. - Київ: ППС-2002, 2007. -

Дия цитирования: Глазков В.А., Аевченков А.И. "Устойчивое развитие»: пробцемы и перспективы: статья // Юридическая мысль. - 2021. - № 4 (124). - С. 40-45.

DOI: $10.47905 /$ MATGIP.2021.124.4.003 


\title{
"Sustainable development": problems and prospects
}

\section{Viktor A. Glazkov* Aleksandr I. Levchenkov**}

\begin{abstract}
Annotation. The article analyzes the concept of sustainable development as a completely natural logical transition from the ecologization of scientific knowledge and socio-economic development to the issues of limited natural resources, as well as pollution of the natural environment, which is the basis of life, economic and any human activity. The authors proceed from the trinity of the main assessment categories that determine sustainable development: economic growth, social responsibility and ecological balance.
\end{abstract} civilization.

Key words: sustainable development, ecology, economic growth, state ideology,

If we recall the winged, absolutely accurate and extremely capacious expression of E. Durkheim that scientific research should not be about the concept of social reality, but it itself, then immediately questions arise regarding the introduction into scientific circulation of the concept of "sustainable development" and its three main components: economic growth, social responsibility and ecological balance.

First, it is immediately clear that these are highly evaluative categories.

Secondly, it is necessary to find out whether there is something really existing behind these concepts or the authors of this "fashionable" concept today have arbitrarily invented a certain categorical apparatus and are trying to sum up objective reality under it, although everyone understands perfectly well that everything should be the other way around.

Thirdly, any scientific theory and conceptual apparatus do not arise by themselves. It is also important to know who its customers are, performers, carriers and what goals they pursue. Legal theory does not exist outside or without socio-economic, political, cultural and other processes and phenomena, but there is their legal form of consolidation and expression.

Fourthly, it is not only economic growth that is important, but its direction, it is only a means to achieve the goal, but what is it itself, due to whom and what is it achieved? Economic growth is accompanied by an increase in the material condition of the entire people, the middle class and oligarchs? How this process proceeds, its intensity, time frame, costs, etc. Perhaps economic growth is expressed in the development of certain, most important sectors of the national economy: space, electronics, the country's defense, agriculture, medicine, etc. Is it accompanied by large losses in the environmental sphere? Is it constant or episodic? etc.?

* Glazkov Viktor Anatolyevich, Rector of the State Institution of LPR "Lugansk Academy of Internal Affairs named after E.A. Didorenko ", candidate of legal sciences, associate professor.

** Levchenkov Aleksandr Ivanovich, First Vice-Rector for Educational and Methodological Work and International Relations of the State Institution of LPR "Lugansk Academy of Internal Affairs named after E.A. Didorenko ", Doctor of Law, Professor. 
Fifthly, behind the liberal-utopian concept of "social responsibility" in the post-Soviet version of the "consumer society" hides an unsuccessful attempt to protect the oligarchic clans from their real, effective large-scale participation in solving socio-economic and political issues in favor of the majority of the population countries, at least through the introduction of progressive taxation, which is typical and is considered a normal democratic procedure in the same France, Finland, Norway and other socially oriented states.

Naturally, these processes should find their expression and consolidation in political and legal ideology, current legislation, moral attitudes cultivated in society, etc.

And if you start moving in this direction, then you need to do this with the reform of Art. 13 of the Constitution of the Russian Federation [1]. Thank God, what we wrote about several years ago has already been done - in the course of the constitutional reform initiated by V.V. Putin, part 4, article 15 of the Constitution of the Russian Federation, which was the basis for interference in the internal affairs of modern Russia from the collective West, received a different vision [1].

Now it's the turn to do the same with the thirteenth article of the country's Basic Law. Ideological pluralism is necessary at the stage of developing the dominant state ideology, but no more.

Today it has become clear and understandable to everyone that in the states of the transitional type, to which the Russian Federation belongs, there is no clear, unified state ideology, including the legal one. The interests of the majority of society (the people), which are not fixed in the existing power programs, are fixed by the national elites, who are often carriers and propagandists of ideas and so-called Western values that are alien to the bulk of the population. The West is the domination of individual values over collective values and the disunity of society according to various criteria. First of all, the material for the Slavic (Soviet) mentality was the dominance of collective values and solidarity. Today, millennial China is living, developing, and becoming the world's leading power by these rules.

Today, the state ideology of Russia, on the one hand, appears as a difficult to combine whole, which includes the best traditions of Soviet patriotism, which is based on the events of the Great Patriotic War, the heroism of the Soviet people and the Great Victory. The second component of the existing state ideology is the approaches and values of the "consumer society", the third component is Russian Orthodoxy. Everyone understands that, in fact, we see an attempt to bring together things that are absolutely incompatible and irreducible. Naturally, such an ideological structure will be shaky, ineffective and not durable.

With the pernicious influence on all aspects of the life of a person of the "consumer society", everything is clear in order to educate a new young generation in the spirit of patriotism, Love for the Motherland and which will not profess and blindly follow the basic Western values - "first think about yourself, and then about the Motherland ", money doesn't smell ", etc., it will take decades and then on condition that young people are provided with a worthy attention alternative of a different worldview and other values. 
The inclusion of the Church in the mechanism of the state can be justified only by the current circumstances unfavorable for the current government, its instability and the need for urgent support from all public institutions, including this one, and can be considered as a temporary measure, for stable and close the material ties of the Church with society and, as a consequence, dependence on it, as the history of distant and close to us shows, undermines its authority in the world as the highest moral authority.

The use of the heroic past of our people (WWII 1941-1945) also has its own time and extreme limits. The no less heroic events of the Patriotic War of 1812 seem quite distant today and not always clear for today's youth. Yes, probably, and the thought of the need to rush with a bunch of grenades under a fascist tank and die does not cause more enthusiasm among the young people of the "consumer society". Although the events in Syria have shown us, as well as the whole world, that everything is not lost here, the revival of high spirituality and manifestations of heroism among the Russian people is still possible.

But to be honest to the end, then, probably, it should also be said that despite the calls that there should be no state or obligatory ideology in the Russian Federation (Article 13 of the Constitution of the Russian Federation), nevertheless it exists, but this the ideology ultimately "consumer society", from which we must get rid of and as quickly as possible. Despite the declared ideological diversity, it is dominant and reacts harshly not only to attempts to reform and retarget it, but even to attempts to bring it out of the "shadow", to show its true face (founders and carriers).

The ideology of a "consumer society" was born in the late 80s of the last century and declared itself in full voice in August 1993 with cannon shots at the building of the Supreme Soviet of the Russian Federation. It was formed in the government offices of the US White House, and then through and with the help of "talking heads" from business, science, culture (Z. Brzezinsky, G. Kissinger, J. Sores, A. Yakovlev, A. Solzhenitsyn, O. Gonchar and others) was introduced into the hearts and minds of our citizens as the only true, reliable and effective direction for the further development of the post-Soviet space. Thus, according to Valentin Rasputin, at this time there was a sacrifice of the Soviet people for the sake of the West.

I.N. Bartsits spoke about this quite clearly, stating that having perceived the Western idea of "consumption", Russian society cannot be satisfied with this, it continues to need a different state idea, justice, in all its manifestations. First of all, in the economic, political and legal spheres [2].

As for the next utopia regarding the possibility of establishing and maintaining an "ecological balance" in modern conditions, the following can be said.

The ecological problem arose and exists today as a specific social problem with the emergence of Homo sapiens. The main thing in the contradiction between society and nature is that man - the son of nature - is more and more separated from it (and this process has become irreversible), opposes and destroys it.

On the production activity of a person (the scale and degree of exploitation of the natural environment), unity, balance and harmony, as well as con- 
frontation and disharmony between society and nature, are based. These relationships record various aspects and stages of their development. It is depending on the nature and development of the world (or a separate state, region) economy that this or that situation, this or that position and this or that structure in the relationship between society and nature are formed. In this regard, it should also be noted that the above components - unity, balance, disharmony, confrontation - characterize different aspects of the maturity and development of this fundamental social contradiction.

The ecological problem, taken in its genesis, is nothing more than a reflection of the history of the relationship between man and nature, which in its development reproduces the stages of growing contradictions between society and nature.

Even the first industrial revolution marked the beginning of the uncontrolled exploitation of earthly riches and the massive pollution of the human environment with wastes of new production activities.

This uncontrolled exploitation of earthly wealth and pollution of the environment has increased a hundredfold in modern conditions. And all this was done and is being done for the sole purpose of obtaining super-profit, a goal that cannot be correlated with either the immediate or the more distant negative consequences of such activities. Now all this leads to an imbalance and confrontation between society and nature, antagonism and contradiction between them, threatens to develop into a global crisis, an obstacle to the further normal existence of mankind.

Today, there are two main dominant trends in the environmental field. The first is based on the intensive simultaneous growth of the material and spiritual culture of mankind, which gives rise to optimistic forecasts for our future civilizational prospects.

At the heart of the other, there is a clear tendency, which is characterized by various factors of an unprecedented anthropogenic load on nature - accelerated, predatory exploitation, reduction and depletion of natural resources, which is accompanied by unrestricted and uncontrolled environmental pollution. This tendency gives rise to justified pessimism regarding the future development of human civilization.

This pessimism is based on the intensive and irrational use of earthly resources, a manifold increase in the amount of industrial waste, the rapid pollution of the biosphere and its components. There are also many signs that indicate that the biological and social nature of man is facing the most serious challenges and tests today - COVID-19, which can lead to multimillion-dollar victims, is direct evidence of this.

One thing is certain, today there is a negative situation of disharmony and confrontation between man and nature, and we can with good reason talk about the presence of two levels of socio-economic, political, economic and cultural contradictions in the modern world. Namely, contradictions at the level of an object - social reality - and contradictions at the level of a subjective factor taken in various spheres of its manifestation.

The essence of objective reasons is that the current level of scientific knowledge of the processes taking place in the world still cannot provide a rad- 
ical solution to the main question - about the permissible measure of human intervention in nature so as not to destroy its harmony and unity with society.

Subjective reasons lie in the fact that in modern society, until now (at all its stages), ecological consciousness, ecological thinking (from leaders of states, national elites and to ordinary citizens) has not yet been formed and what is much more important (there are still no) constructive and coordinated actions in this area of the entire world community. Although lately, in connection with a sharp climate change, declarative statements and rhetoric in this direction are intensifying.

The contradictions considered here are, in modern conditions, according to some experts, the main contradictions between man and nature. The situation in this regard is radically aggravated by the fact that the environment has become, on the one hand, an effective means of solving political problems, and on the other hand, in fact, a "hostage" of politics.

The principles of political expediency and economic benefit become, unfortunately, the main ones and determine specific approaches to solving environmental problems.

A striking example of this is the events around Nord Stream - the sanctions against it. The struggle of states and national elites for or against its construction and commissioning is extremely politicized. The use of environmental problems in the internal party struggle was especially clearly manifested during the elections of the Chancellor of the Federal Republic of Germany and directly the position of the "greens" in these issues. That is, ecology has become an object of great world politics and a means of achieving political goals at its expense.

In such conditions, there can be no talk at all about the balance of the three components of "stable equilibrium". The world today is extremely unbalanced and unable to be, a priori, stable and consolidated. Each state in the context of a systemic global crisis is trying to survive in any way, including through the exploitation of other states and the resources of the Earth.

Otfried Gjofe directly points to the reason for this attitude of man to nature: "The fact that people bring harm to the environment necessary for their survival testifies to their stupidity and directly to myopia and lack of understanding of environmental consequences. The reasons for this lie in the structural shortcomings of the market: while the profit is an act of activity leading to environmental pollution, individual individuals use, and the damage caused goes to the whole society, until then these pollution is difficult to overcome" [3, p. 385].

Also, when studying environmental problems, one should pay attention to the lack of a developed ecological culture among the population of many countries, including post-Soviet ones, and this, unfortunately, applies to both ordinary citizens and officials of different levels, including those who this is spelled out by their official powers.

The resources of the Earth are not unlimited, drinking water is getting smaller, the number of forest plantations and even the "boundless" Siberian taiga, as well as the Amazon forests, are being reduced in a catastrophic manner. The world's oil and gas reserves, as the most demanded energy resources 
in all countries, are also coming to an end today. All of this speaks of the need to search for new comprehensive approaches to solving environmental problems for all world communities, however, for the sake of every minute interest, especially by the leading states, this rule is often not observed.

Naturally, in such a situation, it makes no sense to talk about the "balance" of the three main components of "sustainable development". The answer to this question lies on the surface: economic growth in transitional states (unstable societies) inevitably opposes the ecological environment, since it is carried out due to its exploitation and the decrease in the social function of the state and the enthusiasm for the greed of transnational corporations.

Human civilization has less and less time to solve this, of course, the most important problem, with which its present and future are directly connected.

\section{Bibliographic list}

1. "Constitution of the Russian Federation" (adopted by popular vote on 12.12.1993 with amendments approved during the nationwide vote on 01.07.2020) // www.consultant.ru

2. Bartsits I.N. The doctrine of constitutional patriotism: the European challenge and the Russian perspective // State and law. 2014. P. 5-17. $436 \mathrm{p}$.

3. Otfried Giofe. Democracy in the era of globalization. Kiev: PPS-2002, 2007.

For citation: Glazkov V.A., Levchenkov A.I. "Sustainable development": problems and prospects: article // Legal thought. 2021. No. 4 (124). P. 46-51.

DOI: $10.47905 /$ MATGIP.2021.124.4.003

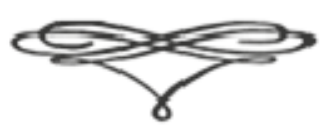




\title{
Истокн формнровання понятня квазнправоОХРАннтельныЕ органы
}

\section{Ф.Г. Груннн" Ф.H. Муравлева*}

\author{
«Мимиция принадмежит народу \\ и народ принадлежит милиции".
}

T. Х. Живков

\begin{abstract}
Аннотация. Настоящая статья обусловлена теоретической и практической значимостью вопросов, связанных с верным восприятием понятийного ряда в отношении современных правоохранительных органов. В ней рассмотрены понятие "квазиправоохранительные органы" с точки зрения генезиса его происхождения и некоторых иных моментов, отражающих данное явление. Кроме того, исследовано влияние псевдосимовых формирований на механизм исполнительной власти в Российской Федерации, инструменты совершенствования и оптимизации, с учетом современного развития права, а также непосредственно самих правоохранительных структур.
\end{abstract}

К^ючевые слова: правоохранительные органы, государственная власть, формирование понятия, генезис, признаки, юридическая наука.

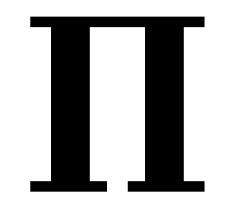

остепенное формирование и распространение псевдосиловых формирований на муниципальном уровне в регионах Российской Федерации, которые могут себе это позволить, чаще всего в научном сообществе считают следствием прошедшей в 2011 году реформы полиции.

В этот период МВД России всецело перешло в централизованное федеральное подчинение и на полное федеральное финансирование в рамках бюджетных обязательств. До реформы "мимиция общественной безопасности" подчинялась федеральным, региональным и местным властями, в рамках своих полномочий.

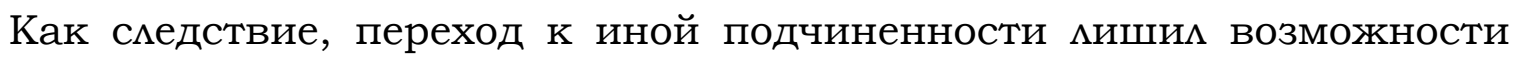
региональные власти и муниципалитеты привлекать полицию для решения своих задач по-своему усмотрения и обязал согласовывать потребность применения данных структур исключительно посредством дополнительных разъяснений.

* Грунин Антон Геннадъевич, преподаватель кафедры управления и административно-правовых дисциплин Вцадимирского юридического института ФСИН России. E-mail: grunin-a-g@yandex.ru

** Муравлева Алина Юрьевна, курсант Владимирского юридического института ФСИН России (г. ВАадимир). E-mail: muravlevaalina@yandex.ru 
Исходя из этого, в таких регионах, как: Кубань, Татарстан, Москва и многих других стали возникать полулегальные квазиправоохранительные новообразования. В некоторых случаях они мимикрируют под якобы традиционные казачьи структуры, добровольческие дружины, общественные организации волонтеров, активистов и прочее.

Бесспорно, что данные преобразования значительным образом повлияли на динамику происходящих трансформаций исполнитемьной ветви вмасти, однако справедмиво будет отметить, что сам процесс протекает с давних пор. Это подтверждается разАичными источниками, в которых прослеживаются некоторые черты современных правоохранительных органов в деятельности отдельных образований, существовавших в более ранние эпохи.

Таким образом, в силу исторического пути формирования, совокупности источников, особенностей правотворчества и правоприменения, наличия ведущих отраслей и других особенностей каждая национальная система права, как правило, одновременно признает несколько базовых источников права, формирующих ее основу, а также ряд квазиисточников, выполняющих вспомогательную роль по отношению к базовым [3, с. 125-126].

Дия того чтобы разобраться со значением термина «квазиправоохранительные органы" (от мат. quasi - нечто вроде, как будто, как бы, псевдо), видится необходимым вникнуть в его смысл и происхождение.

Правоохранительные органы - это специальные органы, созданные государством в целях охраны права, действующие на основании и в соответствии с законом, наделенные правом применения мер принуждения, а в ряде случаев правом применения уголовного закона и обязанностью соблюдения определенной процессуальной формы.

Под приведенное опредемение подпадает большинство правоохранительных органов, в частности полиция, прокуратура, органы безопасности и т.д. Однако у отдемьных образований явно правоохранительной направменности могут отсутствовать некоторые признаки. В качестве примера можно привести такую организацию, стоящую на позиции охраны прав граждан, как адвокатура. Из приведенных признаков к адвокатуре подойдут мишь два: цель деятельности и функционирование на основе закона. Таким образом, формально такие органы нельзя назвать правоохранительными. Однако они, бесспорно, являются правоохранитемьными, по сути и, главное, по целям своей деятемьности.

Дия того чтобы выделить правоохранительный характер деятельности этих органов и в то же время показать, что в узком понимании они не явАяются правоохранительными, представители нижегородской школы процессуалистов (в частности, В. Т. Томин) ввели особый термин «квазиправоохранительные органы". Этот термин образован при помощи матинской приставки "квази -», имеющей два значения: а) мнимый, ненастоящий; б) почти, близко. В данном случае указанная частица применена во втором значении.

Таким образом, квазиправоохранительные органы - это государственные органы, общественные организации и частные институты, оказывающие содействие правоохранительным органам в выполнении их функ- 
ций, а также непосредственно обеспечивающие правовую помощь гражданам и юридическим мицам.

K квазиправоохранительным органам кроме названной уже адвокатуры можно отнести нотариат, органы частной детективной и охранной деятельности; юридическую службу предприятий и организаций [4, c. 8-9].

Рассматривая генезис происходящей трансформации, можно предпоможить, что все признаки правоохранительных органов имелись у казачества; стрелецкого войска; дружины и др.

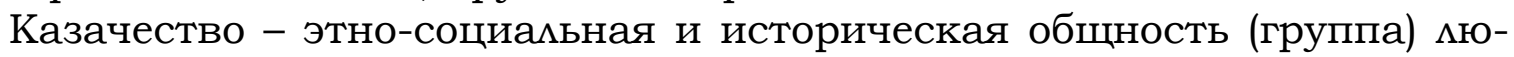
дей - казаков, представителей разцичных народов - русских, украинцев, а также калмыков, бурят, башкир, татар, эвенков, осетин и других - как их субэтносов.

Термин "казаки" был принят на Руси дмя обозначения самостоятельного и самоуправляемого вооруженного населения на различных территориях. Самая крупная группа казаков образовалась в бассейне реки Дон. Это была группа свободных и независимых мюдей, не подчинившихся контролю русских князей.

Русские служивые казаки, согласно первому уставу сторожевой станичной службы, составленному в 1571 князем М. И. Воротынским, называмись городовыми, полковыми и сторожевыми. Они использовались для защиты засечных черт и городов, получали за это жалование и земельные участки в пожизненное владение. По сути данная деятельность - это выполнение полицейских функций, только на раннем этапе развития.

Неоднозначная роль, которую играли казаки в Смутное время, побудима правительство с XVII в. проводить политику резкого сокращения отрядов служивых казаков на основной территории государства. Но в стратегическом плане правительство, учитывая важнейшие функции казаков как военной силы в пограничных районах, проявляло долготерпение и стремимось подчинить себе казачью вольницу.

Таким образом, сейчас законодательство допускает возможность участия казаков в выполнении целого ряда функций органов государственной власти. У них есть цели и полномочия, но все они выражены в оказании содействия государству, сами они никаких действий предпринимать не вправе.

Стрелецкое войско - первое постоянное войско в Русском государстве (середина 16 - начало 18 века). Созданное в 1550 при Иване IV Васильевиче оно постепенно превращались во внутреннюю охрану государства и в боевых действиях русской армии почти не участвовало. Стрелецкое войско делимось на московских и городовых. Первые работали "кремлёвской гвардией", стояли в карауле, воевали за страну. Городовые служили в гарнизонах, стерегли границу, несли полицейскую службу. Тяжёлая служба, постоянные задержки жалованья, зцоупотребления местных властей и своего начальства обусловили участие стрельцов в ряде восстаний, в т. ч. в Стрелецком восстании 1682 и Астраханском восстании 1705-1706. Окончательно стремецкое войско прекратило своё существование в 1713 году. Стремьцам бымо запрещено жить в Москве, а также поступать в солдаты. 
Дружина - княжеское войско. Основными функциями дружины были сбор дани, военные походы и защита князя. "Старшая" дружина состояла из немногих, наиболее знатных дружинников, бывших близкими советниками князя. Старшие дружинники нередко получали от князя право сбора дани в некоторых областях в свою пользу и имели свои дружины. "Молодшая" дружина состояла из "гридей", "отроков", "детских" и др. воинов, составАявших основную массу дружины. Они исполняли различные поручения князя, сопровождали его в качестве свиты и телохранителей. С развитием феодального земмевладения дружинники превращались в земельных собственников - бояр.

Понятие "правоохранительный орган" раскрывается на основе широкого понимания права во взаимосвязи с понятиями институциональной формы права (правового учреждения), правоохранительной деятельности и институциональной организации правоохранительного органа. Известно, что право как общественное явление отличается сложностью, многоаспектностью, проявляет себя на многочисленных уровнях и поэтому выражается юридической мыслью во многих образах.

Правоохранительный орган должен:

- иметь правоохранительный интерес, выраженный в правосудии, защите прав и свобод человека и гражданина, соблюдении режима законности, поддержании общественного порядка и обеспечении общественной безопасности, выявлении, расследовании и предупреждении преступлений и иных правонарушений, оказании юридических услуг;

- подчинен публично-правовому интересу либо согласованному с ним (не противоречащему) общественному или частному интересу;

- институционально организован, т.е. представлять собой систему структурированных органов (подраздемений) или обладать внутренним устройством;

- действовать в порядке, установленном законом путем применения норм этого закона.

Несомненно, что обладающий такими признаками орган является правоохранительным.

Функции правоохранительных органов должны в себя включать: конституционный контроль, расследование нарушений права, обеспечение безопасности, предупреждение правонарушений, прокурорский надзор, исполнение решений суда, оперативный розыск, охрана общественного порядка.

Подводя итоги, важно отметить, что каждый субъект правоохранительной деятельности правильно рассматривать по отдельности и в широком, и в узком смыслах. Утвердительно, отнести его к «правоохранительным органам", или напротив сдемать вывод, что он к таковым не относится нельзя.

Если рассматривать современные признаки деятельности правоохранительных органов, отметим, что их деятельность урегулирована нормативно-правовыми актами, законодатель четко устанавливает правовой порядок их деятельности.

Провозглашение России правовым социальным государством определяет необходимость не только закрепления верховенства права во всех 
сферах жизнедеятельности общества, но и обеспечение его внедрения в практику общественного и государственного строительства, а также повышение уровня законности и правопорядка. В связи с этим, увекичивается роль государства и права, научных разработок проблем сущности, природы и значения институтов правообразования и правотворчества $[1$, c. 48$]$.

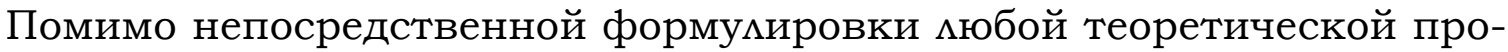
блемы ее непременной составной частью всегда должно являться выяснение условий, реализация которых может быть удовметворительной и адекватной заданным постановкой проблемы рамкам и векторам [2, с. 37].

Таким образом, назвать данные квазиобразования правоохранительными органами будет не совсем верно, так как исторически имелись случаи совершения разбоя, грабежей, убийств, бунтов с их стороны, что не допустимо. При этом данные образования не выполняли задачи и функции правоохранительных органов: обеспечение и защита прав и свобод мичности, общества и государства, охрана общественного порядка и др.

Кроме того, они одному мицу (князь, царь), что, как в случае с Иваном Грозным, закончилось огромным сокращением населения из-за массовых убийств и разорением государства.

Исходя из выше сказанного, их можно отнести к квазиправоохранительным органам, так как они охраняли государственный строй и осуществляли защиту границ государства.

Следовательно, квазиправоохранительные органы - это государственные органы, общественные организации и частные институты, оказывающие содействие правоохранительным органам в выполнении их функций, а также непосредственно обеспечивающие правовую помощь гражданам и юридическим Аицам.

\section{Бибциографический список}

1. Воробъев C.M., Аапшин В.Е., Грунин А.Г. Обеспечение прав и свобод человека на основе соотношения принципов нормотворчества и законности // Теория государства и права. - 2021. № 2 (22). - С. 48-56.

2. Малахов В.П. Условия адекватности постановки вопроса о связи Аичности и государства // Вестник Московского городского педагогического университета. Серия: Юридические науки. - 2018. - № 2 (30). - С. 37-43.

3. Полищук Н.И. Роль квазиисточников права в нормотворческой деятельности государства // Теория государства и права. - 2020. - № 2. - С. 125130 .

4. Правоохранительные органы России: краткий курс мекций / М. П. Поляков, А. В. Федулов, Е. С. Кузьменко. - 7-е изд., перераб. и доп. - М.: Издательство Юрайт, 2014 - 196 с.

Дия цитирования: Грунин А.Г., Муравлева А.Ю. Некоторые предпосылки дмя формирования понятия квазиправоохранительные органы: статья // Юридическая мысль. 2021. - № 4 (124). - С. 52-56.

DOI: 10.47905/ MATGIP.2021.123.4.005 


\title{
Origins of formation of the concept quasi law enforcement bodies
}

\author{
Anton G. Grunin* \\ Alina Yu. Muravleva**
}

"The police belong to the people and the people belong to the police"

T. Kh. Zhivkov

\begin{abstract}
Annotation. This article is driven by theoretical and the practical significance of issues related to the correct perception of the conceptual series in relation to modern law enforcement agencies. It examines the concept of "quasi-law enforcement agencies" from the point of view of the genesis of its origin and some other points that reflect this phenomenon. In addition, the influence of pseudo-force formations on the mechanism of executive power in the Russian Federation, tools for improvement and optimization, taking into account the modern development of law, as well as directly the law enforcement structures themselves, has been investigated.
\end{abstract}

Key words: law enforcement agencies, state power, concept formation, genesis, signs, legal science.

The gradual formation and spread of pseudo-force formations at the municipal level in the regions of the Russian Federation that can afford it, most often in the scientific community is considered a consequence of the police reform that took place in 2011.

During this period, the Ministry of Internal Affairs of Russia was completely transferred to centralized federal subordination and to full federal funding within the framework of budgetary obligations. Prior to the reform, the "public security police" were subordinate to federal, regional and local authorities, within the framework of their powers.

As a result, the transition to a different subordination made it impossible for regional authorities and municipalities to involve the police in solving their tasks at their own discretion and obliged them to agree on the need to use these structures solely through additional clarifications.

Based on this, in such regions as: Kuban, Tatarstan, Moscow and many others, semi-legal quasi-law enforcement neoplasms began to appear. In some cases, they mimic the supposedly traditional Cossack structures, volunteer squads, public organizations of volunteers, activists, and so on.

There is no doubt that these transformations have significantly influenced the dynamics of the ongoing transformations of the executive branch of power, but it will be fair to say that the process itself has been going on for a long time. This is confirmed by various sources that trace some of the fea-

* Grunin Anton Gennadievich, Lecturer of the Department of Management and Administrative and Legal Disciplines of the Vladimir Law Institute of the Federal Penitentiary Service of Russia. E-mail: grunin-a-g@yandex.ru

** Muravleva Alina Yurievna, cadet of the Vladimir Law Institute of the Federal Penitentiary Service of Russia (Vladimir). E-mail: muravlevaalina@yandex.ru 
tures of modern law enforcement agencies in the activities of individual entities that existed in earlier eras.

So, due to the historical path of formation, the totality of sources, the peculiarities of lawmaking and law enforcement, the presence of leading industries and other features, each national legal system, as a rule, simultaneously recognizes several basic sources of law that form its basis, as well as a number of quasi-sources that play an auxiliary role in relation to the basic $[3, \mathrm{p} .125-$ 126].

In order to understand the meaning of the term "quasi-law enforcement agencies" (from Lat. Quasi - something like, as if, as it were, pseudo), it seems necessary to delve into its meaning and origin.

Law enforcement agencies are special bodies created by the state in order to protect the law, acting on the basis and in accordance with the law, endowed with the right to use coercive measures, and in some cases the right to apply criminal law and the obligation to comply with a certain procedural form.

Most of the law enforcement agencies, in particular the police, prosecutors, security agencies, etc., fall under this definition. However, some formations of a clearly law enforcement orientation may lack some signs. As an example, we can cite such an organization that takes the position of protecting the rights of citizens, such as the advocacy. Of the above signs, only two are suitable for the legal profession: the purpose of the activity and the functioning on the basis of the law. Thus, formally, such bodies cannot be called law enforcement. However, they are undoubtedly law enforcement in essence and, most importantly, in terms of the goals of their activities.

In order to highlight the law enforcement nature of the activities of these bodies and at the same time to show that in the narrow sense they are not law enforcement, representatives of the Nizhny Novgorod school of proceduralists (in particular, V. T. Tomin) introduced a special term "quasi-law enforcement bodies". This term is formed using the Latin prefix "quasi", which has two meanings: a) imaginary, fake; b) almost, close. In this case, the specified particle is applied in the second meaning.

Thus, quasi-law enforcement agencies are state bodies, public organizations and private institutions that assist law enforcement agencies in the performance of their functions, as well as directly provide legal assistance to citizens and legal entities.

In addition to the already named legal profession, quasi-law enforcement bodies include notaries, private detective and security bodies; legal service of enterprises and organizations [4, p. 8-9].

Considering the genesis of the ongoing transformation, it can be assumed that the Cossacks had all the signs of law enforcement; Streltsy troops; squads, etc.

The Cossacks are an ethno-social and historical community (group) of people - Cossacks, representatives of various peoples - Russians, Ukrainians, as well as Kalmyks, Buryats, Bashkirs, Tatars, Evenks, Ossetians and others as their sub-ethnic groups.

The term "Cossacks" was adopted in Russia to designate an independent and self-governing armed population in various territories. The largest group of 
Cossacks was formed in the Don River basin. It was a group of free and independent people who did not submit to the control of the Russian princes.

Russian service Cossacks, in accordance with the first charter of the village guard service, drawn up in 1571 by Prince M. I. Vorotynsky, were called police, regimental and sentry. They were used to protect razor lines and cities, received for this salary and land plots for life. In fact, this activity is the implementation of police functions, only at an early stage of development.

The ambiguous role played by the Cossacks in the Time of Troubles prompted the government from the 17 th century to pursue a policy of drastic reduction of detachments of service Cossacks in the main territory of the state. But strategically, the government, taking into account the most important functions of the Cossacks as a military force in the border areas, showed longsuffering and sought to subjugate the Cossack rabble.

Thus, now the legislation allows for the participation of the Cossacks in the performance of a number of functions of state authorities. They have goals and powers, but all of them are expressed in rendering assistance to the state, they themselves have no right to take any action.

Streletskoe Voisko - the first standing army in the Russian state (mid16th - early 18th century). Created in 1550 under Ivan IV Vasilievich, it gradually turned into the internal guard of the state and almost did not participate in the hostilities of the Russian army. The rifle army was divided into Moscow and policemen. The first worked as the "Kremlin guard", stood on guard, fought for the country. The townspeople served in the garrisons, guarded the border, carried out police service. Hard service, constant salary delays, abuses of local authorities and their superiors led to the participation of the archers in a number of uprisings, including the Streletsky uprising of 1682 and the Astrakhan uprising of 1705-1706. The final streltsy army ceased to exist in 1713. Streltsy were forbidden to live in Moscow, as well as to become a soldier.

The squad is a princely army. The main functions of the squad were tribute collection, military campaigns and the protection of the prince. The "senior" squad consisted of a few, the most distinguished warriors, who were close advisers to the prince. Senior vigilantes often received from the prince the right to collect tribute in some areas in their favor and had their own squads. The "young" squad consisted of "gridis", "youths", "children" and other soldiers who made up the bulk of the squad. They carried out various orders of the prince, accompanied him as a retinue and bodyguards. With the development of feudal land tenure, the vigilantes turned into landowners - boyars.

The concept of "law enforcement" is revealed on the basis of a broad understanding of the law in interrelation with the concepts of the institutional form of law (legal institution), law enforcement activity and the institutional organization of the law enforcement body. It is known that law as a social phenomenon is complex, multidimensional, manifests itself on numerous levels and therefore is expressed in legal thought in many ways.

The law enforcement agency should:

- have a law enforcement interest, expressed in justice, protection of the rights and freedoms of man and citizen, observance of the rule of law, main- 
taining public order and ensuring public safety, identifying, investigating and preventing crimes and other offenses, providing legal services;

- is subordinate to a public interest or an agreed (not contradicting) public or private interest;

- institutionally organized, i.e. represent a system of structured bodies (divisions) or have an internal structure;

- to act in the manner prescribed by law by applying the norms of this law.

There is no doubt that the body possessing such characteristics is law enforcement.

The functions of law enforcement agencies should include: constitutional control, investigation of violations of law, security, and prevention of offenses, prosecutor's supervision, and execution of court decisions, operational investigation, and protection of public order.

Summing up, it is important to note that each subject of law enforcement is correctly considered separately in both broad and narrow senses. In the affirmative, it is impossible to classify him as a "law enforcement agency", or, on the contrary, to conclude that he is not one of those.

If we consider the modern signs of the activities of law enforcement agencies, we note that their activities are regulated by regulatory legal acts; the legislator clearly establishes the legal procedure for their activities.

The proclamation of Russia as a legal social state determines the need not only to consolidate the rule of law in all spheres of society's life, but also to ensure its implementation in the practice of social and state building, as well as to increase the level of law and order. In this regard, the role of the state and law, scientific developments of the problems of the essence, nature and significance of the institutions of legal education and law-making is increasing $[1$, p. 48].

In addition to the direct formulation of any theoretical problem, its indispensable component must always be the clarification of conditions, the implementation of which can be satisfactory and adequate to the given formulation of the problem to the framework and vectors [2, p. 37].

Thus, it will not be entirely correct to call these quasi-education law enforcement agencies, since historically there have been cases of robbery, robberies, murders, riots on their part, which is not permissible. At the same time, these entities did not fulfill the tasks and functions of law enforcement agencies: ensuring and protecting the rights and freedoms of the individual, society and the state, protecting public order, etc.

In addition, they are to one person (prince, tsar), which, as in the case of Ivan the Terrible, ended with a huge population decline due to massacres and the ruin of the state.

Based on the above, they can be attributed to quasi-law enforcement agencies, since they guarded the state system and protected the borders of the state.

Consequently, quasi-law enforcement agencies are state bodies, public organizations and private institutions that provide assistance to law enforcement agencies in the performance of their functions, as well as directly provide legal assistance to citizens and legal entities. 


\section{Bibliographic list}

1. Vorobiev S.M., Lapshin V.E., Grunin A.G. Ensuring human rights and freedoms based on the relationship between the principles of rule-making and legality // Theory of State and Law. 2021. No. 2 (22). P. 48-56.

2. Malakhov V.P. Conditions for the adequacy of posing the question of the relationship between the individual and the state // Bulletin of the Moscow City Pedagogical University. Series: Legal Sciences. 2018. No. 2 (30). P. 37-43.

3. Polishchuk N.I. The role of quasi-sources of law in the rule-making activity of the state // Theory of state and law. 2020. No. 2. P. 125-130.

4. Law enforcement agencies of Russia: a short course of lectures / MP Polyakov, A. V. Fedulov, E. S. Kuzmenko. 7th ed., Rev. and add. Moscow: Yurayt Publishing House, 2014. 196 p.

Please cite this paper as: Grunin A.G., Muravleva A.Yu. Some prerequisites for the formation of the concept of quasi-law enforcement bodies: article // Legal thought. 2021. No. 4 (124). P. 57-61.

DOI: 10.47905 / MATGIP.2021.123.4.005

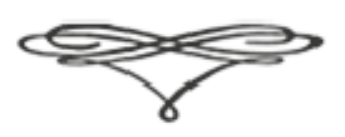




\title{
Оптнмнзацня органнзацнонного овеспечення АЕЯТЕАЬНОСТН СУАОВ: \\ теорня н практнка правового регуннровання *
}

\section{И.И. Корякнн ${ }^{* *}$}

\begin{abstract}
Аннотация. В статье рассматриваются особенности правового регулирования организационного обеспечения деятельности судов в целях его оптимизации, исследуются закономерности разработки эффективных нормативных правовых актов. Автор отстаивает позицию, что содержание организационного обеспечения деятельности судов имеет существенное отличие от организационного руководства судами.
\end{abstract}

Кмючевые смова: суд, судебная власть, обеспечение деятельности судов, нормативный правовой акт, судебные органы, судебные учреждения.

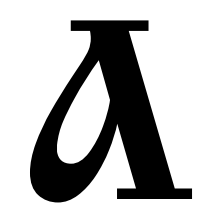

ктуальность проблем, связанных с правовым регулированием оптимизации организационного обеспечения деятецьности судов, отражается в интересе к совершенствованию условий для полного и независимого отправцения правосудия. Основной цемью разрешения проблем явцяется усовершенствование обеспечивающей деятельности судов, которая направлена на гарантирование независимости, неприкосновенности несменяемости судей - основных конституционных принципов организации и деятельности судебной системы. $\mathrm{K}$ сожалению, понятие о проведении правового регулирования оптимизации организационного обеспечения деятельности судов не отражено в российском законодательстве, что вызывает затруднения в осуществлении деятельности аппарата судов и органов системы Судебного департамента, явмяющиеся важными в настоящий период.

Считаем, что сущность правового регулирования оптимизации организационного обеспечения деятельности судов следует понимать как выбор мучшего варианта изо всех имеющихся возможностей в реализации правовых норм российского законодательства аппаратом судов и органами системы Судебного департамента в осуществцении организационного обеспечения деятемьности судов.

Дия достижения цели управления необходимо найти способы создания системы оптимальных решений, содержанием которого явцяется упорядоче-

* Использован материал статьи: Корякин И.И., Степанов А.И. Проблемы правового регулирования оптимизации организационного обеспечения деятельности судов // Административное право и процесс. - 2019. - № 12. - С. 52-55.

** Корякин Иван Иннокентьевич, доцент кафедры конституционного, муниципального и международного права Северо-Восточного федерацьного университета имени M.K. Аммосова, кандидат юридических наук, доцент. E-mail: ivaninnok@mail.ru 
ние общественных отношений, регулирование организации и обеспечения условий функционирования аппарата судов и органов системы Судебного департамента, оптимизации процесса поиска и принятия решений.

Вопрос о проблеме правового регулирования оптимизации организационного обеспечения деятельности судов является одним из кАючевых эмементов современного научного и правового дискурса - целенаправленного рассуждения. Это - вопросы нормотворческой деятельности, которая нуждается в ее оптимизации.

Оптимизация функционирования организационного обеспечения деятельности судов направлена на исследование процессов и закономерностей, происходящих в сфере общественных отношений и разработки эффективных нормативных правовых актов. Имеются проблемы, негативно отражающиеся на качество организационного обеспечения деятельности судов:

- в оптимизации объема полномочий субъектов права - аппарата судов и органов системы Судебного департамента;

- в повышении роли субъектов права: аппарата судов и органов системы Судебного департамента в судебной системе;

- в развитии правового статуса работников аппарата судов и органов системы Судебного департамента;

- в совершенствовании достойного материального и социацьного обеспечения субъектов права;

- в оптимизации механизма исполнения нормативных правовых актов, в т. ч. - ведомственных правовых актов.

В целях совершенствования оптимизации функционирования организационного обеспечения деятельности судов, статуса субъектов права работников аппарата судов и органов системы Судебного департамента целесообразно изучить вопрос о принятии федерального закона "О судебной службе Российской Федерации".

Оптимизации подвергается деятельность органов государственной вмасти или государственных органов. Цемью оптимизации является повышение эффективности их деятельности, а предметом - система организации, которая испытывает потребность в оптимизации. А объектом оптимизации будет деятемьность органов государственной вцасти ими государственных органов.

Проблема - сложный вопрос, задача, требующие разрешения, исследования. Постановка проблемы - способ сделать что-нибудь, организация чегомибо [17, с. 523]. Разработка проблемы правового регулирования оптимизации организационного обеспечения деятельности судов позволила прийти к однозначному выводу: это выявление наилучшего варианта средств, способов совершенствования управленческой деятемьности аппарата судов, органов системы Судебного департамента, правового регулирования общественных отношений и использование механизма правового регулирования общественных отношений, возникающих в организационном обеспечении деятельности судов для достижения цели в процессе правотворчества и правоприменения.

В процессе организационного обеспечения деятельности судов выявились следующие проблемы оптимизации: 
во-первых, еще не решены проблемы законотворческой деятельности в сфере организационного обеспечения деятельности судов;

во-вторых, еще не решены вопросы прогнозирования в подготовке программ развития в организационном обеспечении деятельности судов. Нормотворческий процесс должен быть основой государственной федеральной программы, а также субъектов Федерации. Дия повышения качества нормативных правовых актов в сфере организационного обеспечения деятельности судов учитывается организующее начало норм права в системе регулирования управленческих отношений;

в-третьих, принятые законы и подзаконные акты страдают повторами норм одного и того же содержания, нормотворческая деятельность страдает множественностью нормативных правовых актов, необоснованностью применения непонятных всем терминов, что иногда порождает противоречия;

в-четвертых, остаются малоэффективными внесенные изменения в законопроекты, которые не приносят заметных результатов, страдает качество законов;

в-пятых, своевременно не признаются утратившие силу нормативные правовые акты, которые фактически не действуют как таковые;

в-шестых, оптимизация нормотворческой деятемьности в сфере организационного обеспечения деятельности судов требует согласования действий соответствующих органов законодательной и исполнительной властей на всех уровнях.

Исходя из мексического значения слова "оптимизация" [нат. optimus наилучший] важно сдемать выбор кучшего варианта изо всех имеющихся или возможных; привести систему в наилучшее состояние; найти экстремахьное (наибольшее или наименьшее) значение какой-либо функции [18]. Поэтому, несомненно, то, что основами правового регулирования оптимизации организационного обеспечения деятельности судов явцяются:

во-первых, необходимое обеспечение верховенства законов в системе ведомственных актов Судебного департамента и аппарата судов по вопросам организационного обеспечения деятельности судов с целью регулирования конкретных общественных отношений;

во-вторых, достижение эффективности нормотворческой деятельности аппарата судов и органов системы Судебного департамента, соблюдение правиц юридической техники, от которых зависит качество ведомственных актов. Избегать неправильного согласования, написания слов, сложных и непонятных фраз, стилистической погрешности, способствовать разъяснению принимаемых ведомственных актов;

в-третьих, минимизация дубцирования нормативных правовых актов;

в-четвертых, согласованность действий нормотворческой инициативы субъектов;

в-пятых, достижение эффективности нормотворчества в реализации ведомственных нормативных правовых актов;

в-шестых, профессиональное использование существующей автоматизированной справочной правовой системы (Консультант-Плюс, Гарант и др.) для ознакомления с актами федерального уровня и уровня субъектов Федерации. 
Каждый нормативный правовой акт должен учитывать факторы, учитывающие потребность в правовом регулировании существующих общественных отношений в сфере организационного обеспечения деятельности судов, в определении наиболее оптимального варианта регулирования рассматриваемых общественных отношений.

Существенной проблемой является опредемение и раскрытие предмета и содержания нормативных правовых актов, которыми регулируются государственно-служебные отношения. Следует обратить внимание на структуру этих правовых отношений, учесть права и обязанности субъектов, опредемить объекты управления в сфере организационного обеспечения деятельности судов, возникновение, изменение и прекращение правоотношений, специфику государственной гражданской службы в аппарате судов и органах системы Судебного департамента.

В юридической митературе верно отмечается, что качественное правовое регулирование деятельности аппаратов судов и системы Судебного департамента будет способствовать должному выполнению обязанности государства, указанной в ст. 124 Конституции Российской Федерации о централизованном финансировании судов из федерального бюджета, которое способствует полному и независимому осуществлении правосудия [1].

Как трактуется в юридической митературе, по Н.M. Конину, суть правового регулирования заключается в установлении государством юридических норм с собственно правовым содержанием [15, с. 46], а С.А. Комаров считает, что оптимизация правотворческой деятельности, как законодательной, так и подзаконной, требует согласования действий разАичных нормотворческих органов [12, с. 317].

Рассматривая проблему содержания организационного руководства судами, отметим, что исследование вопроса о полномочиях аппаратов судов и системы Судебного департамента - организационного обеспечения деятельности судов в Российской Федерации связано с отношением государства к механизму правового регулирования. Как известно, в последнее время были использованы разные модели организационной деятельности судов, но эти модеми подверглись объективной критике. Были предложены и использованы две модели: они осуществлялись или органами юстиции, или высшими судебными органами. Выбрана вторая модемь, согласно которой, процессы финансирования федеральных судов осуществляются из средств федерального бюджета, что домжно обеспечивать условие для полного и независимого отправления правосудия согласно федеральному законодательству, а также достижения реальности закрепления принципа финансово-экономической достаточности в функционировании судебной системы. Предоставленные государством гарантии независимости в системе судебной власти до 1993 года имели только декларативный характер.

Kaк известно, в советское время органы исполнительной власти (Министерство юстиции СССР и др.) занимались организационным руководством судебной системой, что привецо систему судебной власти к зависимости от органов исполнительной вцасти, ими, в первую очередь, решались основные организационные вопросы деятецьности судов. 
В соответствии с нормами ст. 18 «Основы законодательства о судопроизводстве Союза ССР, союзных и автономных республик" было возможено в полном объеме организационное руководство судами на Министерство юстиции Союза ССР [2].

Согласно законодательству в суть организационного руководства судами входимо: разработка предложений по организации судов (дислокация, структура, штаты, проведение выборов судей и народных заседателей); руководство организацией отчетов судей перед избирателями; проверка организации работы судебных органов; создание надлежащих условий дмя осуществления правосудия; обеспечение судебных органов квалифицированными кадрами, организация переподготовки и повышения квалификации указанных кадров; изучение и обобщение судебной практики в целях дальнейшего совершенствования деятельности судов; организация работы по ведению судебной статистики; осуществление руководства и контроля работы по исполнению судебных постановлений по гражданским и уголовным делам. Тем самым исполнительной власти страны оказывалось воздействие на судебную деятельность, в том числе на осуществление беспристрастного и независимого правосудия.

Как видно, содержание организационного обеспечения деятельности судов имеет существенное отличие от организационного руководства судами. Такой подход существовал до конца 90-х гг. прошлого столетия и это было характерным явлением: в деятельности Министерства юстиции СССР в отношении судов использовалось понятие "организационное руководство судами" (ст. 19 Закона РСФСР от 8 июля 1981 г. "О судоустройстве РСФСР») [14, с. 147]. В содержании данного Закона дмя Министерства юстиции СССР ставилась задача всемерного содействия в осуществлении задач суда, строгого соблюдения принципа независимости судей и подчинения их советскому законодательству. Органы юстиции СССР пользовались определенным правом проверять организацию работы судов и деятельность по работе с кадрами судов.

Принятие российского законодательства в части создания Судебного департамента [3] стало одной из значимых мер, которое имело цель упорядочения деятельности в организационном, кадровом и ресурсном обеспечении судов общей юрисдикции и органов судейского сообщества, укрепмения независимой деятемьности судебной власти.

Исходя из содержания ст. 31 Федерацьного конституционного закона "О судебной системе Российской Федерации" [3], можно констатировать, что была создана отдемьная структура: Судебный департамент - исполнительный орган судебной власти, деятельность которого направлена на организационное обеспечение деятельности судов и это диктовалось такими обстоятельствами:

во-первых, необходимостью искцючить влияние на судебную власть органов исполнительной власти, прежде всего органов юстиции Российской Федерации - органа исполнительной власти, которые были со времен советской вцасти связаны с деятецьностью судов;

во-вторых, недопустимостью расширения функций аппарата судов, не свойственных ему, направленных на организационное обеспечение их деятемьности; 
в третьих, правовое регулирование организационного обеспечения деятельности судов вкцючает в себя сочетание норм права, которые регумируют определенный сегмент общественных отношений на правовом поле в укреплении самостоятельности судов, независимости судей.

Следует признать, что специфика функций, а также организационная структура аппарата судов и органов системы Судебного департамента устанавцивает и особенности правового регулирования его работы. В функционировании системы механизма правового регулирования в организационно-правовом обеспечении судов играют роль правовые акты, включающие: нормативные акты, мокальные акты, акты применения, акты толкования ими разъяснения, которые издаются органами судебной вмасти и их домжностными мицами.

Правовые нормы нормативных актов регулируют отношения в сфере правовой инфраструктуры Судебного департамента - исполнительного органа судебной власти дмя создания надлежащих условий в его эффективном функционировании, условия для правового регулирования оптимизации организационного обеспечения деятельности судов.

В данном случае, Судебный департамент, являясь исполнительным органом судебной власти, отличается от других органов государственной вцасти назначением, содержанием своей деятецьности и ее характером.

В юридической митературе верно отмечается, что часто применяют различные виды нормативных правовых актов: административно-правовой акт $[10 ; 11$, с. 33; 24, с. 216; 26], правовой акт управления [22, с. 340$368 ; 25]$, нормативный правовой акт [5; 9, с. $18-22 ; 15$, с. 42-44; 21, с. $177-$ $180 ; 23$, с. 18-20]. Содержание этих терминов имеет одинаковый смыс , сходство и тождественное понятиям "администрация", "управцение" и "упорядочение». Из-за отсутствия заметной разницы, будем употребцять термин "нормативный правовой акт".

В ходе работы над проектом нормативного правового акта, требуется знание законодательства, а также изучение научной митературы о нем. Рассмотрение и анализ митературы приводит к выводу о том, что ученые опредеАяют нормативный правовой акт через категории: "решение" [20, с. 286], правовые документы [10, с. 8], государственно-властные действия [6, с. 241; 8, с. 17], правовую форму управленческой деятемьности [19, с. 11], правовой акт управления [7, с. 375; 16, с. 375].

Исходя из этого, можно сдемать вывод о деятельности органов судебной вцасти по подготовке, принятию, изданию нормативного правового акта, который представляет собой письменный документ, принятый аппаратом судов и органами системы Судебного департамента, с помощью которого в пределах своей компетенции устанавливаются, изменяются или отменяются правовые нормы в целях достижения цели и реализации полномочий в процессе осуществцения функций государства организационного и материально-технического характера.

На основании анализа основных законодательных источников правового регулирования организационной структуры институтов судебной системы, положений Федерального конституционного закона "О судебной системе Российской Федерации" сделаем вывод о том, что судебная система 
состоит из органов и учреждений, которые обеспечивают их деятельность на единых правовых основах, объединяют в единое целое принципы и задачи $[14$, с. XI-XII].

Из Конституции Российской Федерации [13, с. 270] и Федерального конституционного закона "О судебной системе Российской Федерации" [3, 14], следует, что нормативные правовые акты - это федеральные конституционные и федеральные акты, регулирующие организацию и деятельность судов разных уровней и специализации, их организационное обеспечение (кадровое, финансовое, материально-техническое, организационноправовое, электронное и информационно-цифровое).

Как известно, Верховный Суд Российской Федерации инициировал подготовку и обсуждение законопроекта о системе судов. Предстоит решить вопрос о совершенствовании административной юстиции, кроме того, ставится задача создания специальных судебных органов: системы ювенальной юстиции, и других специализированных судов.

Учитывая положения Федерального конституционного закона "О судах общей юрисдикции в Российской Федерации" [4], считаем насущной потребность в правовой жизни принятие федеральных законов, которые будут определять не только порядок организации и деятельности судов, но также и порядок обеспечения их деятельности. Учитывая вышесказанное, считаем, что эти нововведения в судебной системе требуют расширения функций аппаратов судов и Судебного департамента. Должны быть приняты новые нормативные правовые акты, регулирующие организационное обеспечение деятемьности этих судов.

\section{Бибциографический список}

1. "Конституция Российской Федерации" (принята всенародным голосованием 12.12.1993 с изменениями, одобренными в ходе общероссийского голосования 01.07.2020) // www.consultant.ru

2. Основы законодательства о судоустройстве Союза ССР, союзных и автономных республик / / Ведомости Верховного Совета СССР. - 1971. - № 33. - Ст. 332.

3. Федеральный конституционный закон от 31.12.1996 г. № 1-ФК3 (ред. от 30.10.2018) "О судебной системе Российской Федерации" // Собрание законодательства Российской Федерации. - 1997. - № 1. - Ст. 1.

4. Федерахьный конституционный закон от 07.02.2011 № 1-ФКЗ (ред. от 08.12.2020) "О судах общей юрисдикции в Российской Федерации" // www. consultant.ru

5. Постановление Правительства Российской Федерации от 13 августа 1997 г. № 1009 «Об утверждении Правил подготовки нормативных правовых актов федеральных органов исполнительной вмасти и их государственной регистрации" // Собрание законодательства РФ. - 1997. - № 33. - Ст. 3895.

6. Алехин А.П., Кармолиикий А.А., Козлов Ю.М. Административное право. M., 1999. - 671 c.

7. Бахрах Д.Н., Россинский Б.В., Старилов Ю.Н. Административное право. M., 2008. - 816 c.

8. Васильев Р.Ф. Правовые акты органов управления. - М., 1970. - 108 с.

9. Волков А.М., Дугенеи А.С. Административное право. - М., 2013. - 288 с.

10. Гвоздева А.Н. Индивидуальные административные правовые акты: Дисс. ... канд.юрид.наук. - Киров, 2009. - 216 с. 
11. Елагин Р.И. Административное право России. - М., 2011. - 376 с.

12. Комаров, С. А. Общая теория государства и права: учебник для вузов / С. А. Комаров. - 9-е изд., испр. и доп. - М.: Издательство Юрайт, 2020. - 506 с.

13. Комментарий к Конституции Российской Федерации / С. А. Комаров [и др.]; под ред. С.А. Комарова. - 3-е изд., перераб. и доп. - М.: Издательство Юрайт, 2020. - 333 с. - (Серия: Профессиональные комментарии).

14. Комментарий к Федеральному конституционному закону "О судебной системе Российской Федерации". - М., 1998. - 326 с.

15. Конин Н.М. Административное право России. - М., 2011. - 448 с.

16. Коренев А.П. Административное право. - М., 2008.

17. Словарь русского языка. С.И. Ожегов. - М., 1984. - С. 523.

18. Новейший словарь иностранных слов и выражений. - М., 2002.

19. Ноздрачев А.Ф. Нормативные акты министерств и ведомств СССР: автореф. дисс... канд. юрид. наук. - М., 1968. - 17 с.

20. Попов А.А., Мигачев Ю.И., Тихомиров Ю.А. Административное право. - М., 2009. - 688 c.

21. Рассолов М.М. Проблемы теории государства и права. - М.: ЮНИТИДАНА, 2007. - $431 \mathrm{c.}$

22. Старилов Ю.Н. Общее административное право. - Воронеж: Издательство Воронежского государственного университета, 2007. - С. 340-368.

23. Смоленский М.Б., Алексеева М.В. Административное право. - Ростов-наДону, 2015. - 284 с.

24. Четвериков В.С. Административное право. - М., 2013. - 351 с.

25. Шопина О.В. Система правовых актов в современной России: дисс.... канд.юрид.наук. - Саратов, 2002. - 220 с.

26. Яхин Ф.Ф. Действие административно-правовых актов: автореф. дисс. ... канд. юрид. наук. - М., 2004. - 24 с.

ДАя цитирования: Корякин И.И. Оптимизация организационного обеспечения деятельности судов: теория и практика правового регулирования: статья // Юридическая мысль. - 2021. - No. 4 (124). - С. 62-69.

DOI: $10.47905 /$ MATGIP.2021.124.4.004

\section{Organizational support optimization activities of vessels: theory and practice of legal regulation*}

\section{Ivan I. Koryakin*}

Annotation. The article examines the features of legal regulation of the organizational support of the activities of courts in order to optimize it, examines the patterns of development of effective regulatory legal acts. The author defends the position that the content of the organizational support of the activities of the courts has a significant difference from the organizational management of the courts.

${ }^{*}$ Used material of the article: Koryakin I.I., Stepanov A.I. Problems of legal regulation of optimization of organizational support for the activities of courts // Administrative law and process. 2019. No. 12. P. 52-55.

* Koryakin Ivan Innokentievich, Associate Professor of the Department of Constitutional, Municipal and International Law, North-Eastern Federal University named after M.K. Ammosova, Candidate of Legal Sciences, Associate Professor. E-mail: ivaninnok@mail.ru 
Key words: court, judicial power, ensuring the activities of courts, normative legal act, judicial authorities, judicial institutions.

The urgency of the problems associated with the legal regulation of the optimization of the organizational support of the activities of the courts is reflected in the interest in improving the conditions for full and independent administration of justice. The main goal of resolving the problems is to improve the support activities of the courts, which are aimed at guaranteeing the independence, inviolability of the irremovability of judges - the basic constitutional principles of the organization and operation of the judicial system. Unfortunately, the concept of legal regulation of the optimization of the organizational support of the activities of the courts is not reflected in Russian legislation, which causes difficulties in the implementation of the activities of the apparatus of the courts and bodies of the system of the Court Department, which are important at the present time.

We believe that the essence of legal regulation of optimization of organizational support for the activities of courts should be understood as the choice of the best option from all available opportunities in the implementation of legal norms of Russian legislation by the apparatus of the courts and the bodies of the system of the Judicial Department in the implementation of organizational support for the activities of courts.

To achieve the goal of management, it is necessary to find ways to create a system of optimal decisions, the content of which is the ordering of public relations, regulation of the organization and provision of conditions for the functioning of the apparatus of the courts and bodies of the Judicial Department system, optimization of the search process and decision-making.

The issue of the problem of legal regulation of the optimization of the organizational support of the activities of the courts is one of the key elements of modern scientific and legal discourse - purposeful reasoning. These are issues of rule-making activity that needs to be optimized.

Optimization of the functioning of the organizational support of the activities of the courts is aimed at studying the processes and patterns occurring in the field of public relations and the development of effective regulatory legal acts. There are problems that negatively affect the quality of organizational support for the activities of courts:

- in optimizing the scope of powers of subjects of law - the apparatus of the courts and bodies of the system of the Judicial Department;

- in enhancing the role of subjects of law: the apparatus of the courts and the bodies of the system of the Judicial Department in the judicial system;

- in the development of the legal status of employees of the apparatus of the courts and bodies of the system of the Judicial Department;

- in improving decent material and social security for subjects of law;

- in optimization of the mechanism of execution of normative legal acts, including - departmental legal acts.

In order to improve the optimization of the functioning of the organizational support of the activities of the courts, the status of subjects of law - employees of the apparatus of the courts and bodies of the system of the Judicial 
Department, it is advisable to study the issue of adopting the federal law "On the judicial service of the Russian Federation".

The activities of state authorities or state bodies are subject to optimization. The purpose of optimization is to increase the efficiency of their activities, and the subject is the system of the organization, which is in need of optimization. And the object of optimization will be the activities of state authorities or state bodies.

The problem is a complex issue, a task that requires resolution, research. Problem statement is a way to do something, to organize something $[17$, p. 523]. The development of the problem of legal regulation of the optimization of the organizational support of the activities of the courts allowed us to come to an unambiguous conclusion: this is the identification of the best option for means, ways to improve the management activities of the apparatus of the courts, bodies of the Judicial Department, legal regulation of public relations and the use of the mechanism of legal regulation social relations arising in the organizational support of the activities of the courts to achieve the goal in the process of legal creation and law enforcement.

In the process of organizational support for the activities of the courts, the following optimization problems emerged:

firstly, the problems of lawmaking in the field of organizational support for the activities of courts have not yet been resolved;

secondly, the issues of forecasting in the preparation of development programs in the organizational support of the activities of courts have not yet been resolved. The rule-making process should be the basis of the state federal program, as well as the subjects of the Federation. To improve the quality of normative legal acts in the field of organizational support for the activities of courts, the organizing principle of the rule of law in the system of regulation of managerial relations is taken into account;

thirdly, the adopted laws and by-laws suffer from repetitions of norms of the same content, rule-making activity suffers from a plurality of normative legal acts, the unreasonable use of terms that are incomprehensible to everyone, which sometimes gives rise to contradictions;

fourthly, the amendments made to the bills remain ineffective, which do not bring noticeable results, the quality of laws suffers;

fifthly, the invalid normative legal acts, which in fact do not act as such, are not recognized in a timely manner;

sixth, the optimization of rule-making activities in the field of organizational support for the activities of courts requires coordination of the actions of the relevant legislative and executive authorities at all levels.

Based on the lexical meaning of the word "optimization" [lat. optimus the best] it is important to choose the best option from all available or possible; bring the system to the best possible condition; find the extreme (maximum or minimum) value of any function [18]. Therefore, it is undoubted that the foundations of legal regulation for the optimization of the organizational support of the activities of the courts are:

firstly, the necessary provision of the rule of law in the system of departmental acts of the Judicial Department and the apparatus of courts on the 
issues of organizational support of the activities of courts in order to regulate specific social relations;

secondly, the achievement of the effectiveness of the rule-making activity of the apparatus of courts and bodies of the system of the Judicial Department, compliance with the rules of legal technique, on which the quality of departmental acts depends. Avoid incorrect coordination, spelling of words, difficult and incomprehensible phrases, stylistic errors, help to clarify the adopted departmental acts;

third, minimization of duplication of regulatory legal acts;

fourth, the consistency of the actions of the rule-making initiative of the subjects;

fifth, the achievement of the effectiveness of rule-making in the implementation of departmental regulatory legal acts;

sixth, the professional use of the existing automated reference legal system (Consultant-Plus, Garant, etc.) to get acquainted with the acts of the federal level and the level of the subjects of the Federation.

Each normative legal act should take into account factors that take into account the need for legal regulation of existing public relations in the field of organizational support of the activities of the courts, in determining the most optimal option for regulating the public relations in question.

A significant problem is the definition and disclosure of the subject and content of regulatory legal acts that govern state-service relations. Attention should be paid to the structure of these legal relations, to take into account the rights and obligations of the subjects, to determine the objects of management in the field of organizational support for the activities of the courts, the emergence, change and termination of legal relations, the specifics of the state civil service in the apparatus of courts and the bodies of the Judicial Department system.

In the legal literature, it is correctly noted that high-quality legal regulation of the activities of the apparatus of the courts and the system of the Judicial Department will contribute to the proper fulfillment of the duty of the state specified in Art. 124 of the Constitution of the Russian Federation - on the centralized financing of courts from the federal budget, which contributes to the full and independent administration of justice [1].

As interpreted in the legal literature, according to N.M. Konin, the essence of legal regulation is the establishment by the state of legal norms with their own legal content [15, p. 46], and S.A. Komarov believes that the optimization of law-making activities, both legislative and subordinate, requires the coordination of the actions of various rule-making bodies [12, p. 317].

Considering the problem of the content of the organizational leadership of the courts, we note that the study of the issue of the powers of the apparatus of the courts and the system of the Judicial Department - the organizational support of the activities of the courts in the Russian Federation is associated with the attitude of the state to the mechanism of legal regulation. As you know, recently various models of the organizational activity of courts have been used, but these models have been objectively criticized. Two models were proposed and used: they were carried out either by the justice authorities or by 
the highest judicial authorities. The second model has been chosen, according to which the processes of financing federal courts are carried out from the federal budget, which should provide a condition for the full and independent administration of justice in accordance with federal legislation, as well as achieving the reality of consolidating the principle of financial and economic sufficiency in the functioning of the judicial system. The guarantees of independence provided by the state in the system of the judiciary until 1993 were only declarative in nature.

As you know, in Soviet times, the executive authorities (the Ministry of Justice of the USSR, etc.) were involved in the organizational management of the judicial system, which led the judicial system to dependence on the executive authorities, they, first of all, solved the main organizational issues of the activities of courts.

In accordance with the provisions of Art. 18 "Fundamentals of Legislation on Judicial Proceedings of the USSR, Union and Autonomous Republics" was entrusted in full with the organizational leadership of the courts at the Ministry of Justice of the USSR [2].

According to the legislation, the essence of the organizational management of the courts included: development of proposals for the organization of courts (location, structure, staff, holding elections of judges and people's assessors); management of the organization of reports of judges to voters; checking the organization of the work of the judiciary; creation of appropriate conditions for the administration of justice; provision of the judiciary with qualified personnel, organization of retraining and advanced training of these personnel; study and generalization of judicial practice in order to further improve the activities of the courts; organization of work on the maintenance of judicial statistics; management and control of work on the execution of court orders in civil and criminal cases. Thus, the executive power of the country had an impact on judicial activity, including the implementation of impartial and independent justice.

As you can see, the content of the organizational support of the activities of the courts has a significant difference from the organizational management of the courts. This approach existed until the end of the 90s. last century and this was a characteristic phenomenon: in the activities of the Ministry of Justice of the USSR in relation to the courts used the concept of "organizational leadership of the courts" (Art. 19 of the RSFSR Law of July 8, 1981 "On the court system of the RSFSR") [14, p. 147]. The content of this Law for the Ministry of Justice of the USSR set the task of all possible assistance in the implementation of the tasks of the court, strict observance of the principle of independence of judges and their subordination to Soviet legislation. The judicial authorities of the USSR enjoyed a certain right to check the organization of the work of the courts and the work with the personnel of the courts.

The adoption of Russian legislation in terms of the creation of the Judicial Department [3] was one of the most significant measures, which had the goal of streamlining activities in the organizational, personnel and resource support of courts of general jurisdiction and bodies of the judicial community, strengthening the independent activity of the judiciary. 
Based on the content of Art. 31 of the Federal Constitutional Law "On the Judicial System of the Russian Federation" [3], it can be stated that a separate structure was created: the Judicial Department is an executive body of the judiciary, whose activities are aimed at organizing the activities of the courts and this was dictated by the following circumstances:

firstly, the need to exclude the influence on the judiciary of the executive authorities, primarily the judicial authorities of the Russian Federation - the executive authority, which have been associated with the activities of the courts since Soviet times;

secondly, the inadmissibility of expanding the functions of the apparatus of the courts, not characteristic of it, aimed at the organizational support of their activities;

thirdly, the legal regulation of the organizational support of the activities of the courts includes a combination of legal norms that regulate a certain segment of public relations in the legal field in strengthening the independence of the courts, the independence of judges.

It should be recognized that the specifics of the functions, as well as the organizational structure of the apparatus of the courts and bodies of the system of the Judicial Department, also establish the features of the legal regulation of its work. In the functioning of the system of the mechanism of legal regulation in the organizational and legal support of courts, legal acts play a role, including: normative acts, local acts, acts of application, acts of interpretation or explanations that are issued by the judicial authorities and their officials.

The legal norms of normative acts regulate relations in the field of legal infrastructure of the Judicial Department - the executive body of the judiciary to create appropriate conditions for its effective functioning, conditions for legal regulation of the optimization of the organizational support of the courts.

In this case, the Judicial Department, being the executive body of the judicial power, differs from other bodies of state power in the purpose, content of its activities and its nature.

In the legal literature, it is correctly noted that various types of regulatory legal acts are often used: an administrative-legal act $[10 ; 11$, p. 33; 24, p. 216; 26], legal act of management [22, p. 340-368; 25], normative legal act [5; 9, p. $18-22 ; 15$, p. 42-44; 21, p. 177-180;23, p. 18-20]. The content of these terms has the same meaning, similarity and identical to the concepts of "administration", "management" and "ordering". Due to the lack of a noticeable difference, we will use the term "regulatory legal act".

In the course of work on a draft regulatory legal act, knowledge of the legislation is required, as well as the study of scientific literature about it. Consideration and analysis of the literature leads to the conclusion that scientists define a normative legal act through the categories: "decision" [20, p. 286], legal documents [10, p. 8], state-power actions [6, p. 241; 8, p. 17], the legal form of management activities [19, p. 11], legal act of management [7, p. 375; 16, p. 375].

Based on this, we can conclude about the activities of the judicial authorities in the preparation, adoption, publication of a normative legal act, which is a written document adopted by the apparatus of the courts and the 
bodies of the Judicial Department system, with the help of which, within its competence legal norms are established, changed or canceled in order to achieve the goal and exercise powers in the process of exercising the functions of the state of an organizational and logistical nature.

Based on the analysis of the main legislative sources of legal regulation of the organizational structure of the institutions of the judicial system, the provisions of the Federal Constitutional Law "On the Judicial System of the Russian Federation", we conclude that the judicial system consists of bodies and institutions that ensure their activities on unified legal framework, combine principles and objectives into a single whole [14, p. XI-XII].

From the Constitution of the Russian Federation [13, p. 270] and the Federal Constitutional Law "On the Judicial System of the Russian Federation" $[3,14]$, it follows that regulatory legal acts are federal constitutional and federal acts regulating the organization and activities of courts of different levels and specialization, their organizational support - teaching (personnel, financial, material and technical, organizational and legal, electronic and digital information).

As you know, the Supreme Court of the Russian Federation initiated the preparation and discussion of the draft law on the system of courts. It is necessary to resolve the issue of improving administrative justice; in addition, the task is to create special judicial bodies: a system of juvenile justice, and other specialized courts.

Taking into account the provisions of the Federal Constitutional Law "On Courts of General Jurisdiction in the Russian Federation" [4], we consider the urgent need in legal life to adopt federal laws that will determine not only the procedure for organizing and operating courts, but also the procedure for ensuring their activities. Taking into account the above, we believe that these innovations in the judicial system require the expansion of the functions of the apparatus of the courts and the Judicial Department. New normative legal acts should be adopted to regulate the organizational support of the activities of these courts.

\section{Bibliographic list}

1. "The Constitution of the Russian Federation" (adopted by popular vote on 12.12.1993 with amendments approved during the all-Russian vote on 01.07.2020) // www.consultant.ru

2. Fundamentals of legislation on the judicial system of the USSR, union and autonomous republics // Bulletin of the Supreme Soviet of the USSR. 1971. No. 33. Art. 332.

3. Federal Constitutional Law of 31.12.1996, No. 1-FKZ (as amended on 30.10.2018) "On the judicial system of the Russian Federation" / / Collected Legislation of the Russian Federation. 1997. No. 1. Art. 1.

4. Federal Constitutional Law of 07.02.2011 No. 1-FKZ (as revised on 08.12.2020) "On courts of general jurisdiction in the Russian Federation" // www. consultant.ru

5. Decree of the Government of the Russian Federation of August 13, 1997 No. 1009 "On approval of the Rules for the preparation of regulatory legal acts of federal executive bodies and their state registration" // Collected Legislation of the Russian Federation. 1997. No. 33. Art. 3895. 
6. Alekhin A.P., Karmolitskiy A.A., Kozlov Yu.M. Administrative law. Moscow, 1999. $671 \mathrm{p}$.

7. Bakhrakh D.N., Rossinsky B.V., Starilov Yu.N. Administrative law. Moscow, 2008. 816 p.

8. Vasiliev R.F. Legal acts of governing bodies. Moscow, 1970. 108 p.

9. Volkov A.M., Dugenets A.S. Administrative law. Moscow, 2013. 288 p.

10. Gvozdeva A.N. Individual administrative legal acts: Diss. ... Candidate of Legal Sciences. Kirov, 2009. 216 p.

11. Elagin R.I. Administrative law of Russia. Moscow, 2011. 376 p.

12. Komarov, S.A. General theory of state and law: a textbook for universities / S.A. Komarov. 9th ed., rev. and add. Moscow: Yurayt Publishing House, 2020. 506 p.

13. Commentary on the Constitution of the Russian Federation / S. A. Komarov [and others]; ed. S.A. Komarov. 3rd ed., rev. and add. Moscow: Yurayt Publishing House, 2020. 333 p. (Series: Professional Commentary).

14. Commentary on the Federal Constitutional Law "On the Judicial System of the Russian Federation". Moscow, 1998. 326 p.

15. Konin N.M. Administrative law of Russia. Moscow, 2011. 448 p.

16. Korenev A.P. Administrative law. Moscow, 2008.

17. Dictionary of the Russian language. S.I. Ozhegov. Moscow, 1984. P. 523.

18. The newest dictionary of foreign words and expressions. Moscow, 2002.

19. Nozdrachev A.F. Normative acts of ministries and departments of the USSR: abstract of thesis diss ... Candidate of Legal Sciences. Moscow, 1968. 17 p.

20. Popov L.L., Migachev Yu.I., Tikhomirov Yu.A. Administrative law. Moscow, 2009. $688 \mathrm{p}$.

21. Rassolov M.M. Problems of the theory of state and law. Moscow, 2007. 431 p.

22. Starilov Yu.N. General administrative law. Voronezh: Voronezh State University Publishing House, 2007. P. 340-368.

23. Smolenskiy M.B., Alekseeva M.V. Administrative law. Rostov-on-Don, 2015. 284 p.

24. Chetverikov V.S. Administrative law. Moscow, 2013. 351 p.

25. Shopina O.V. The system of legal acts in modern Russia: Diss.... Candidate of Legal Sciences. Saratov, 2002. 220 p.

26. Yakhin F.F. The action of administrative legal acts: abstract of thesis. diss.... Cand. jurid. sciences. Moscow, 2004. 24 p.

For citation: Koryakin I. I. Optimization of organizational support for the activities of courts: theory and practice of legal regulation: article // Legal thought. 2021. No. 4 (124). P. 69-76.

DOI: 10.47905 / MATGIP.2021.124.4.004

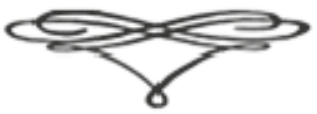




\title{
Размышияя О АОстнженнн ЭффекТнвностн норматнвныХ правовыХ АКТОВ
}

\section{E.R. Мнцкая*}

\begin{abstract}
Аннотация. В статье приводятся примеры несовершенства норм некоторых законов в силу сложности их применения, проблем юридической техники. Особое внимание обращается на предложения усилить ответственность за коррупционные правонарушения в новой Концепции антикоррупционной политики Казахстана, в которых также усматривается не только нарушение юридической техники, но и противоречие доктрине уголовного права, что требует глубокой теоретической проработки.

Ключевые слова: эффективность нормативных правовых актов, уголовный закон, проблемы правоприменения, юридическая техника, нестабильность законодательства.
\end{abstract}

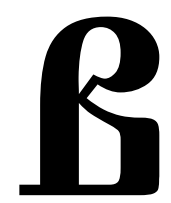

несение поправок в нормативные правовые акты бывает обусловлено развитием социальных условий жизни, которые вводят коррективы в общественные отношения, побуждая смемо изменять и дополнять действующие нормативные правовые

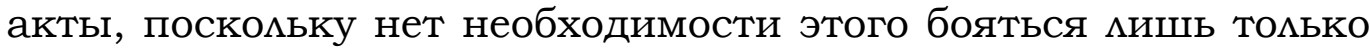
потому, что они прошии парламентское утверждение. И примеров тому достаточно. Так, была жизненная необходимость ввести в УК РФ склонение к совершению самоубийства и содействие его совершению, а также криминализовать организацию деятельности, направленной на побуждение к совершению самоубийства [1]. На что положительно отреагировала казахстанская общественность, ученые, увидев необходимость аналогичного введения в УК РК, потому что на данный момент эти действия остаются криминально нейтральными при их повышенной степени общественной опасности. В целях усиления борьбы с новыми способами распространения наркотиков, в УК РК была введена статья 299-1, устанавливающая уголовную ответственность за пропаганду или незаконную рекламу наркотических средств, психотропных веществ или их аналогов, прекурсоров [2].

Введение данной статьи отвечает общественным потребностям. За 2020 год в Казахстане было выявлено 5,8 тысячи уголовных правонарушений в сфере незаконного оборота наркотиков, что на 4,6\% больше, чем в 2019 году. И объем изымаемых наркотических средств и психотропных

* Мицкая Елена Владимировна, профессор кафедры конституционного и административного права Юридического института (Санкт-Петербург); профессор кафедры уголовного права и уголовного процесса Южно-Казахстанского университета им. М. Ауэзова (Республика Казахстан, Шымкент). E-mail: elenamits@inbox.ru 
веществ не идет на снижение. Объем изъятых наркотиков вырос на три тонны и составил 22,5 тонны, а синтетических увеличился более чем на 90 килограммов [3]. Да, благодаря ст. 299-1 УК РК к уголовной ответственности стало возможным привцекать всех тех, кто посредством графффити-надписей, использования электронньх информационньх ресурсов осуществляет пропаганду наркотических средств, психотропных веществ или их аналогов, прекурсоров. Но ст. 299-1 УК РК не была проверена на предмет ее согласованности со ст. 423 Кодекса РК об административных правонарушениях.

В настоящее время диспозиция ст. 299-1 УК РК полностью дублирует диспозицию ст. 423 Кодекса PK об административных правонарушениях, что может привести к искажению принятия процессуального решения, повлечь не достижение неотвратимости уголовного наказания. Не исключается коррупционная составляющая такого дублирования норм. Хотя ст. 299-1 УК РК стала часто применяемой на практике. В сравнении с УК РФ пропаганда наркотических средств не закреплена, она по-прежнему остается административным правонарушением, а введённая ст. 230 УК РФ имеет сложности применения, поскольку дмя квалификации склонения необходимо доказать прямой умысец на принуждение к употреблению наркотиков конкретного мица. Тогда, когда дия пропаганды наркотиков наличие конкретного мица-потерпевшего не требуется.

Нельзя не сказать о том, что обновление законодательства осуществмяется не только из-за того, что необходимо заменять устаревшие правовые нормы, вводить нормы необходимые для более эффективного правового регулирования, но и из-за низкого качества принимаемых законов, несовершенство которых влечет за собой проблемы при их применении [4, с.5]. С чем нельзя не согласиться. Действительно, не всегда изменения и дополнения вносятся в нормативные правовые акты из-за изменения общественных отношений. Во многом, на наш взгляд, они являются следствием неправильного применения приемов юридической техники, отрицательно влияющего на качество разработанных нормативных правовых актов и приводящего в итоге к нестабильности законодательства. Причем, открытое обсуждение проектов законов, как показывает практика, также не исключает его комлизий, не устраняет проблем его дальнейшего применения. В частности, новый Административный процедурно-процессуальный кодекс РК, практика применения которого только начинает нарабатываться с 1 июля этого года, прошедший публичное обсуждение, имеет ряд нареканий в отношении его качества с точки зрения юридической техники [5, с.21; 6,7].

Особое внимание хотелось бы обратить на некоторые планируемые изменения УК РК по усилению ответственности за совершение коррупционных правонарушений, предмагаемые в проекте Концепции антикоррупционной политики на 2022-2026 годы [8] в рамках его обсуждения. Бесспорно, несмотря на то, что Казахстан за 2020 год занял 94 место из 180 стран в международном Индексе восприятия коррупции (для сравнения: 2019 год - 113 место, 2018 год - 124 место) [9], "действующее законодательство и присущие для казахстанского права институты обладают неиспользованным потенциалом для противодействия коррупции" [10]. Однако, некоторые предможения новой разработанной Концепции антикорруп- 
ционной политики PK по изменению УК РК идут в разрез с устоявшейся доктриной уголовного права, требуют глубокой теоретической проработки.

Так, введение уголовной ответственности за обешание получить взятку и предложение дачи взятки абсолютно несостоятельно.

Во-первых, нельзя исключать того, что мицо может дать обещание помучить взятку, как и сделать предложение дать взятку, но в момент ее передачи или до ее передачи категорично и добровольно откажется от ее помучения, а добровольный отказ от получения взятки в силу ст. 26 УК РК исключает привлечение к уголовной ответственности. Следовательно, обещание получить взятку в этом случае может стать просто не применяемым на

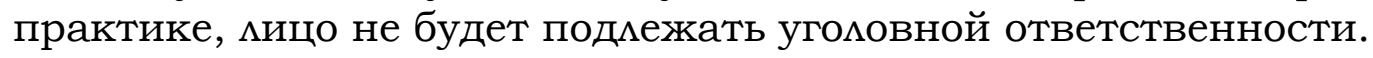

Во-вторых, если обещание получить взятку или предложение дачи взятки криминализовать, то это действие получает наивысшую степень криминализации, поскольку обещание получить взятку будет приготовлением преступления, но за приготовление ответственность наступает по действующему УК РК только за тяжкие или особо тяжкие преступления, а также за приготовление к террористическому преступлению. Соответственно, не все составы получения взятки относятся к тяжким и особо тяжким, а введя угомовную ответственность за обещание получить взятку - это значит мибо надо все составы получения взятки уровнять и сделать тяжкими и особо тяжкими, мибо вводить уголовную ответственность за приготовление к преступлению средней тяжести, тем самым нивелируя разницу между приготовлением и покушением. K тому же, обещание получения взятки становится в один ряд с приготовлением к террористическому преступлению, что нарушает понимание степени общественной опасности уголовно-нака-зуемых деяний.

В-третьих, мысль, выраженная вслух, в данном случае пока не найдет внешней реализации не может быть признана объективным признаком состава преступления. Это к тому, что обещание получить взятку или предможение дачи взятки без реального получения взятки или передачи взятки будет тяжело доказуемым на практике, потому что можно пообещать получить взятку или предложить дать взятку, но без истинного или реального намерения это сделать на самом деме. Причем, субъективная стороны как элемента состава данного преступления не будет установлена в той доста-

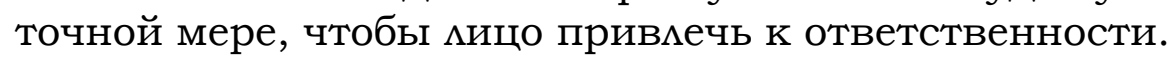

Насколько криминализация обещания получить взятку и предложения дачи взятки будет устрашающей очень сомнительно, потому что на практике больше шансов у мица избежать уголовной ответственности в силу недоказуемости реальных его намерений, чем быть привлеченным к ответственности за эти действия. Обещание получить взятку и предложение дачи взятки это мишь намерение, но это не означает окончательного, безусловного выполнения данного намерения. Возникает вопрос: а как должно быть выражено данное намерение - кивком головы, подмигнуть глазом или молчание - знак согласия? Очевидно, что процессуальная доказуемость факта обещания получить взятку и предложения дачи взятки, даже при признании их оконченным составом преступления, не имеет четкого выражения, она размыта.

Кроме того, согласно Нормативному постановлению Верховного суда PK № 8 от 27.11.2015 г. ответственность за провокацию взятки по ч.2 ста- 
тьи 417 УК РК наступает мишь в случаях, когда попытка передачи предмета взятки осуществлялась в целях искусственного формирования доказа-

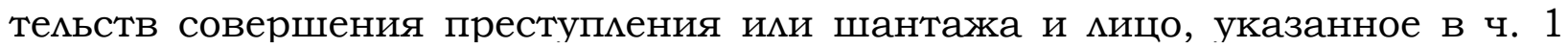
ст. 366 УК (т.е. взяткополучатель), заведомо для виновного не совершало действий, свидетельствующих о его согласии принять взятку. К тому же, в настоящий момент в рамках УК РК и УПК РК невозможно провести разграничение между допустимой имитацией взяточничества и его провокацией, что чревато также всевозможными коррупционными рисками.

Введение уголовной ответственности за торговлю влиянием видится также преждевременным. В силу того, что в Конвенции ООН против коррупции змоупотребление влиянием в корыстных целях охватывает и обещание/предложение/передачу незаконного преимущества мицу, которое утверждает, что может оказать незаконное вцияние на служебное мицо, а также просьбу/получение/принятие предможения или обещания такого преимущества за такое влияние - независимо от того, было ми в действительности

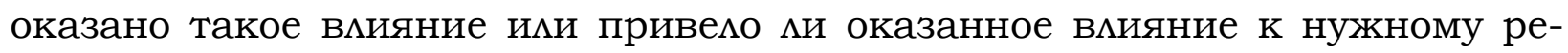
зуцьтату, то казахстанская доктрина уголовного права не преследует за намерение, которое не получило дальнейшего внешнего проявцения. Аналогично тому, как и с обещанием, получить взятку и предложением дачи взятки. Кроме того, УК РК имеет ст. 307 "ЗАоупотребление должностными полномочиями" и ст.308 «Превышение власти или должностных полномочий".

Введение уголовной ответственности юридических лии за коррупиионные правонарушения видится также не состоятельным в силу противоречия устоявшейся доктрине уголовного права Казахстана, кроме того, присоединяемся к отрицательной позиции по данному вопросу сообщества предпринимателей и законодательных органов Казахстана.

Отмене кратности итрафов за коррупиионные правонарушения домжен предшествовать глубокий анализ правоприменительной практики за всё время действия УК РК 2014 года. Кратность штрафа была заимствована в УК РК из зарубежной практики. Последние изменения в УК РК по увеличению размеров кратных штрафов за дачу взятки и посредничество во взяточничестве соответствуют усилению уголовно-правовых мер пресечения данных правонарушений. Однако, вопрос о применении штрафа домжен быть решен судьей с учетом материального положения подсудимого согласно ч.3 ст.41 УК РК, иначе исполнение приговора станет нереальным. В то время как установление штрафа в кратном размере практически искАючает такую возможность, поскольку нижний предец кратности высокий. В этом видится комлизия норм УК РК. Но если и отменять кратность штрафа за коррупционные правонарушения, то не за особо тяжкие преступления, как предлагается в проекте Концепции антикоррупционной по-

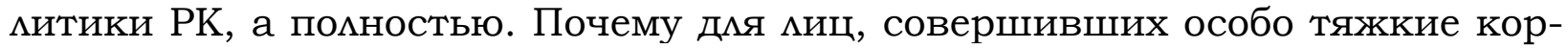
рупционные преступления, должна быть такая привилегия?

Введение таких изменений в УК РК, как: 1) закрепить в УК РК в диспозиции ст. 366 в части первой наряду с материалыными благами и нематериальные блага как предмет взятки, а также создание неправомерных преимуществ в результате их получения. Закрепив нематериальные блага в качестве предмета взятки, будет устранено понимание взятки как исключительно мате- 
риальных выгод; 2) вернуть запрет на освобождение от уголовной ответственности в связи с истечением срока давности за коррупционные преступления, который убрали из ч.6 ст.71 в 2018 г., отсутствие такого запрета не соответствует намерениям непримиримой борьбы с коррупцией; 3) расширить в УК PK определение публичного должностного мица, включив в него руководителей субъектов квазигосударственного сектора, политических партий, а также чиенов семьи и близких (связанных) миц публичного должностного мица, по нашему мнению, будет способствовать усилению уголовно-правовой борьбы с коррупционной преступностью, не создавая проблем при их применении.

Таким образом, прямая зависимость правоприменения от состояния законодательства требует большой работы по приведению законодательства в соответствие с действительностью, по достижению эффективности нормативных правовых актов, обосновывающих то, что все нормы, составмяющие ту или иную форму, должны быть внутренне согласованы, представлять в комплексе определенное единство [11, р.216]. Несоблюдение этого требования может препятствовать применению данной формы. Внутреннее единство важно дия того, чтобы фрорма оказывала соответствующее воздействие на содержание.

Выбранная дмя регумирования общественных отношений правовая форма должна состоять из норм, образующих в целом форму как систему. Вместе с тем каждая норма может оказывать соответствующее влияние на поведение, создавать его эффективную мотивацию. И если все нормы, составляющие форму, взаимно согласованы, представляют собой единство, то только тогда форма в целом может быть эффективна. Если же такого единства нет, то мотивация различных поступков не согласована и в результате действие данной правовой формы в целом в значительной мере ограничивается, а иногда и просто парализуется [12, с. 61]. Кроме того, правовая форма ююбого вида отношений представцяет собой замкнутую, но не изолированную систему. Она находится в тесной связи с другими организационными и правовыми формами, которые в совокупности и составляют единую систему правового регулирования общественных отношений. Поэтому дмя того, чтобы конкретная правовая форма была эффективной, необходима ее согласованность с другими организационными и правовыми формами.

Эта взаимная согласованность определяется внутренним единством системы права и единством правового регулирования общественных отношений. Следовательно, при выборе и определении правовой формы того или иного вида общественных отношений существенное значение должно иметь место этой формы в общей системе правового регулирования и ее соответствие с другими правовыми формами, так как такая взаимная согласованность нормативных правовых актов, опосредующих определенные экономические, политические, социальные и другие отношения, служит необходимым условием их эффективного применения, основывающаяся на общепризнанных поможениях теории права. Результатом отсутствия согласованности разцичных нормативных правовых актов будет являться недостаточное воздействие права на общественные отношения, требующие правового регулирования, а значит и недостаточное действие правоприменительных органов, реализующих государственно-правовое воздействие на общественные отношения. 


\section{Бибциографический список}

1. Уголовный кодекс Российской Федерации от 13 июня 1996 года № 63-Ф3 // URL:// http://www.consultant.ru

2. Уголовный кодекс Республики Казахстан от 3 июля 2014 года № 226-V // URL:// www.online.zakon.kz

3. Почти 6 тысяч правонарушений, связанных с наркотиками, выявмено в Казахстане // https://www.inform.kz/

4. Методические рекомендации по оформлению нормативных правовых актов (юридическая техника): Методическое пособие / Рук. авт. комл. и ред. Р.К. Сарпеков. - Астана: ГУ “Институт законодательства Республики Казахстан”, 2019. - 163 с.

5. Мuикая E.B. О сущности и принципах административной юстиции Наука. - 2020. - № 1 (64). - С. 18-24.

6. Мицкая E.B. Несовершенство административной процедуры: препятствие надлежащей реализации права на обращение. - Наука. - 2020. - № 4 (67). - С. 3-9.

7. Мuикая E.В. Недостатки законодательного закрепления термина "обращение" и каждого вида обращения в Административном процедурно-процессуальном кодексе Республики Казахстан. - Наука. - 2020. - № 3 (66). - С. 19-25.

8. Концепция антикоррупционной политики на 2022-2026 годы // https:// www.gov.kz/memleket/entities/anticorruption/documents/details/227922

9. Transparency Kazakhstan // http://tikazakhstan.org/

10. Указ Президента Республики Казахстан от 26 декабря 2014 года № 986 "Об Антикоррупционной стратегии Республики Казахстан на 2015-2025 годы" // http: // www. adilet.zan.kz

11. Mitskaya E., Shkabin G. Criminal Legal Regulation of Lawful Infliction of Harm in the Course of Covert Actions of Law Enforcement Agencies (Legislative Experience of the Republic of Kazakhstan) // VII International Scientific-Practical Conference "Criminal Law and Operative Search Activities: Problems of Legislation, Science and Practice". CLOSA, 2021. Pp. 214-218. $488 \mathrm{c}$.

12. Государство. Право. Экономика / Отв. ред. Чхиквадзе В.М. - М., 1970. -

Дия цитирования: Мищкая E.В. Размышляя о достижении эффективности нормативных правовых актов: статья // Юридическая мысль. - 2021. - No. 4 (124). - P. 77-82.

DOI: 10.47905 / MATGIP.2021.124.4.006

\section{Reflecting on achieving the effectiveness of regulatory acts}

\section{Elena V. Mitskaya*}

Annotation. The article gives examples of imperfect norms of some laws due to the complexity of their application, problems of legal technique. Particular attention is paid to the proposals to increase liability for corruption offenses in the new concept of anticorruption policy of Kazakhstan, which also seen not only a violation of legal technique, but also contrary to the doctrine of criminal law, which requires a deep theoretical study.

* Mitskaya Elena Vladimirouna, Professor of the Department of Constitutional and Administrative Law of the Law Institute (St. Petersburg); Professor of the Department of Criminal Law and Criminal Procedure of M. Auezov South Kazakhstan University (the Republic of Kazakhstan, Shymkent). 
Keywords: effectiveness of normative legal acts, criminal law, problems of law enforcement, legal technique, instability of legislation.

Amendments to normative legal acts are caused by the development of social conditions of life, which introduce adjustments in social relations, prompting boldly to change and supplement existing normative legal acts, since there is no need to be afraid of this just because they have passed parliamentary approval. And there are enough examples of this.

Thus, there was a vital need to introduce in the Criminal Code of the Russian Federation the inducement to commit suicide and to facilitate its commission, as well as to criminalize the organization of activities aimed at encouraging suicide [1]. To which the Kazakh public and scientists reacted positively, seeing the need for a similar introduction in the Criminal Code of the Republic of Kazakhstan, because at the moment these actions remain criminally neutral with their increased degree of public danger.

In order to strengthen the fight against new ways of spreading drugs, Article 299-1 was introduced in the Criminal Code of the Republic of Kazakhstan, establishing criminal liability for the propaganda or illegal advertising of narcotic drugs, psychotropic substances or their analogues, precursors [2].

The introduction of this article responds to public needs. In 2020, 5.8 thousand criminal offenses in the field of illegal drug trafficking were detected in Kazakhstan, which is $4.6 \%$ more than in 2019. And the volume of seized narcotic drugs and psychotropic substances is not going to decrease. The volume of seized drugs increased by three tons and amounted to 22.5 tons, while synthetic drugs increased by more than 90 kilograms [3]. Yes, thanks to Art. 299-1 of the Criminal Code of the Republic of Kazakhstan, it became possible to bring to criminal responsibility all those who, through graffiti-inscriptions, the use of electronic information resources, propagandize narcotic drugs, psychotropic substances or their analogues, precursors. But Art. 299-1 of the Criminal Code of the Republic of Kazakhstan has not been checked for its consistency with Art. 423 of the Code of Administrative Offenses of the Republic of Kazakhstan.

Currently, the disposition of Art. 299-1 of the Criminal Code of the Republic of Kazakhstan completely duplicates the disposition of Art. 423 of the Code of the Republic of Kazakhstan on Administrative Offenses, which can lead to a distortion of the adoption of a procedural decision, entail not achieving the inevitability of criminal punishment. The corruption component of such a duplication of norms is not excluded. Although Art. 299-1 of the Criminal Code of the Republic of Kazakhstan has become frequently used in practice. In comparison with the Criminal Code of the Russian Federation, the propaganda of narcotic drugs is not enshrined; it still remains an administrative offense, and the introduced Art. 230 of the Criminal Code of the Russian Federation has difficulties in application, since for the qualification of declination it is necessary to prove the direct intent to compel a particular person to use drugs. When for the promotion of drugs the presence of a specific victim is not required.

It should be said that the legislation is being updated not only because it is necessary to replace outdated legal norms, to introduce norms necessary for more effective legal regulation, but also because of the low quality of the adopted laws, the imperfection of which entails problems with their application 
[4, p. 5]. With which one cannot but agree. Indeed, changes and additions are not always made to regulatory legal acts due to changes in public relations.

In many ways, in our opinion, they are a consequence of the incorrect application of legal techniques, which negatively affects the quality of the developed normative legal acts and, as a result, leads to the instability of legislation. Moreover, an open discussion of draft laws, as practice shows, also does not exclude its conflicts, does not eliminate the problems of its further application. In particular, the new Administrative procedural procedural code of the Republic of Kazakhstan, the practice of which is only beginning to be developed from July 1 of this year, which has passed public discussion, has a number of complaints about its quality from the point of view of legal technology [5, p. 21;6;7].

I would like to draw special attention to some planned changes in the Criminal Code of the Republic of Kazakhstan to increase responsibility for committing corruption offenses, proposed in the draft Concept of anticorruption policy for 2022-2026 [8] as part of its discussion. Undoubtedly, despite the fact that in 2020 Kazakhstan took 94th place out of 180 countries in the international Corruption Perceptions Index (for comparison: 2019 - 113th place, 2018 - 124th place) [9] institutions have untapped potential for combating corruption" [10]. However, some proposals of the newly developed Concept of anti-corruption policy of the Republic of Kazakhstan on changing the Criminal Code of the Republic of Kazakhstan go against the established doctrine of criminal law and require deep theoretical study.

Thus, the introduction of criminal liability for the promise to receive a bribe and the offer to give a bribe is absolutely untenable.

First, it cannot be ruled out that a person may promise to receive a bribe, as well as make an offer to give a bribe, but at the time of its transfer or before its transfer, he categorically and voluntarily refuses to receive it, and voluntary refusal to receive a bribe by virtue of Art. 26 of the Criminal Code of the Republic of Kazakhstan exclude criminal prosecution. Consequently, the promise to receive a bribe in this case may simply not be applied in practice; the person will not be subject to criminal liability.

Secondly, if the promise to receive a bribe or an offer to give a bribe is criminalized, then this action receives the highest degree of criminalization, since the promise to receive a bribe will be the preparation of a crime, but for the preparation, responsibility comes under the current Criminal Code of the Republic of Kazakhstan only for grave or especially grave crimes, as well as for preparation for a terrorist crime. Accordingly, not all the elements of receiving a bribe are grave and especially grave, and introducing criminal liability for a promise to receive a bribe means either it is necessary to equalize all the compositions of receiving a bribe and make it grave and especially grave, or introduce criminal liability for preparing for a crime of average gravity, thereby leveling the difference between cooking and attempting. In addition, the promise of receiving a bribe is on a par with the preparation for a terrorist crime, which violates the understanding of the degree of public danger of criminal acts.

Thirdly, a thought expressed aloud, in this case, until it finds an external realization, cannot be recognized as an objective sign of corpus delicti. This means that a promise to receive a bribe or an offer to give a bribe without actually 
receiving a bribe or giving a bribe will be difficult to prove in practice, because one can promise to receive a bribe or offer to give a bribe, but without a true or real intention to actually do it. Moreover, the subjective side as an element of the corpus delicti will not be established sufficiently to bring the person to justice.

To what extent the criminalization of a promise to receive a bribe and an offer to give a bribe will be very daunting, because in practice a person has more chances to avoid criminal liability due to the unprovability of his real intentions than to be held accountable for these actions. A promise to receive a bribe and an offer to give a bribe is only an intention, but this does not mean the final, unconditional fulfillment of this intention.

The question arises: how should this intention is expressed - with a nod of the head, wink an eye, or silence - a sign of consent? It is obvious that the procedural provability of the fact of a promise to receive a bribe and an offer to give a bribe, even if recognized as a completed crime, does not have a clear expression, it is blurred. In addition, according to the Normative Decree of the Supreme Court of the Republic of Kazakhstan No. 8 dated November 27, 2015, responsibility for provoking a bribe under Part 2 of Article 417 of the Criminal Code of the Republic of Kazakhstan occurs only in cases when an attempt to transfer the subject of a bribe was carried out in order to artificially generate evidence of a crime or blackmail and the person specified in Part 1 of Art. 366 of the Criminal Code (i.e., the bribe-taker), knowingly for the perpetrator, did not commit any actions indicating his consent to accept the bribe. In addition, at the moment, within the framework of the Criminal Code of the Republic of Kazakhstan and the Criminal Procedure Code of the Republic of Kazakhstan, it is not possible to distinguish between acceptable imitation of bribery and its provocation, which is also fraught with all kinds of corruption risks.

Criminalizing influence trading is also seen as premature. Due to the fact that in the UN Convention against Corruption, the abuse of influence for personal gain also includes the promise / offer / transfer of an illegal advantage to a person who claims to have an illegal influence on an official, as well as a request / receipt / acceptance of an offer or promise of such an advantage for such influence - regardless of whether such an influence was actually exerted or whether the influence exerted has led to the desired result, the Kazakh doctrine of criminal law does not prosecute an intention that has not received further external manifestation. Likewise with the promise to receive a bribe and the offer to give a bribe. In addition, the Criminal Code of the Republic of Kazakhstan has Art. 307 "Abuse of official powers" and Article 308 "Excess of power or official power.

The introduction of criminal liability of legal entities for corruption offenses also seems inconsistent due to the contradiction with the established doctrine of criminal law in Kazakhstan; in addition, we join the negative position on this issue of the community of entrepreneurs and legislative bodies of Kazakhstan.

The abolition of the multiplicity of fines for corruption offenses should be preceded by a deep analysis of law enforcement practice for the entire period of the Criminal Code of the Republic of Kazakhstan in 2014. The multiplicity of the fine was borrowed in the Criminal Code of the Republic of Kazakhstan from foreign practice. Recent changes in the Criminal Code of the Republic of Kazakhstan to increase the size of multiple fines for giving a bribe and mediation in 
bribery correspond to the strengthening of criminal law measures to suppress these offenses. However, the issue of the application of the fine must be decided by the judge, taking into account the financial situation of the defendant in accordance with Part 3 of Article 41 of the Criminal Code of the Republic of Kazakhstan, otherwise the execution of the sentence will become unrealistic.

At the same time, the establishment of a penalty in a multiple of the amount practically excludes such a possibility, since the lower limit of the multiplicity is high. This is seen as a conflict of norms of the Criminal Code of the Republic of Kazakhstan. But if the multiplicity of the fine for corruption offenses is canceled, then not for especially grave crimes, as proposed in the draft Concept of the anti-corruption policy of the Republic of Kazakhstan, but completely. Why should there be such a privilege for those who have committed especially grave corruption crimes?

Introduction of such changes in the Criminal Code of the Republic of Kazakhstan, such as:

1) fix in the Criminal Code of the Republic of Kazakhstan in the disposition of Art. 366 in part one, along with material benefits and intangible benefits as a subject of bribes, as well as the creation of undue advantages as a result of their receipt. By fixing intangible benefits as the subject of a bribe, the understanding of a bribe as exclusively material benefits will be eliminated;

2) return the ban on exemption from criminal liability in connection with the expiration of the statute of limitations for corruption crimes, which was removed from part 6 of article 71 in 2018, the absence of such a ban does not correspond to the intentions of an irreconcilable fight against corruption;

3) expand the definition of a public official in the Criminal Code of the Republic of Kazakhstan, including the heads of the subjects of the quasi-public sector, political parties, as well as family members and close (related) persons of a public official, in our opinion, will contribute to strengthening the criminal law fight against corruption crime without creating problems in their application.

Thus, the direct dependence of law enforcement on the state of legislation requires a lot of work to bring legislation in line with reality, to achieve the effectiveness of regulatory legal acts, justifying the fact that all the norms that make up one form or another must be internally agreed, to represent a certain unity in the complex. [11, p. 216]. Failure to comply with this requirement may prevent the application of this form. Internal cohesion is important for the form to have a corresponding effect on the content.

The legal form chosen for the regulation of social relations should consist of norms that form the whole form as a system. At the same time, each norm can have a corresponding influence on behavior, create its effective motivation. And if all the norms that make up the form are mutually agreed, represent a unity, then only then the form as a whole can be effective. If there is no such unity, then the motivation of various actions is not coordinated and as a result, the action of this legal form as a whole is largely limited, and sometimes simply paralyzed [12, p. 61].

In addition, the legal form of any kind of relationship is a closed, but not isolated system. It is in close connection with other organizational and legal forms, which together constitute a single system of legal regulation of social relations. Therefore, in order for a specific legal form to be effective, it must be consistent with other organizational and legal forms. 
This mutual consistency is determined by the internal unity of the system of law and the unity of the legal regulation of social relations. Consequently, when choosing and determining the legal form of a particular type of social relations, this form should take place in the general system of legal regulation and its compliance with other legal forms, since such mutual consistency of normative legal acts mediating certain economic, political, social and other relations, serves as a prerequisite for their effective application, based on the generally recognized provisions of the theory of law.

The result of the lack of consistency of various normative legal acts will be an insufficient impact of the law on public relations requiring legal regulation, and hence an insufficient action of law enforcement agencies that implement state-legal impact on public relations.

\section{Bibliographic list}

1. The Criminal Code of the Russian Federation of June 13, 1996 No. 63-FZ // URL: // http:/ /www.consultant.ru

2. The Criminal Code of the Republic of Kazakhstan dated July 3, 2014 No. 226-V // URL: // www.online.zakon.kz

3. Almost 6 thousand drug-related offenses were detected in Kazakhstan // https://www.inform.kz/

4. Guidelines for the design of regulatory legal acts (legal technique): Methodological guide / Guides. ed. call and ed. R.K. Sarpekov. Astana: State Institution "Institute of Legislation of the Republic of Kazakhstan", 2019. 163 p.

5. Mitskaya E.V. On the essence and principles of administrative justice // The science. 2020. No. 1 (64). P. 18-24.

6. Mitskaya E.V. Imperfection of the administrative procedure: an obstacle to the proper exercise of the right to appeal // The science. 2020. No. 4 (67). P. 3-9.

7. Mitskaya E.V. Disadvantages of legislative consolidation of the term "appeal" and each type of appeal in the Administrative procedural procedural code of the Republic of Kazakhstan // The science. 2020. No. 3 (66). P. 19-25.

8. The concept of anti-corruption policy for 2022-2026 // https://www.gov.kz/ memleket/entities/anticorruption/documents/details /227922

9. Transparency Kazakhstan // http://tikazakhstan.org/

10. Decree of the President of the Republic of Kazakhstan dated December 26, 2014 No. 986 "On the Anti-Corruption Strategy of the Republic of Kazakhstan for 2015-2025" // http: // www. adilet.zan.kz

11. Mitskaya E., Shkabin G. Criminal Legal Regulation of Lawful Infliction of Harm in the Course of Covert Actions of Law Enforcement Agencies (Legislative Experience of the Republic of Kazakhstan) // VII International Scientific-Practical Conference "Criminal Law and Operative Search Activities: Problems of Legislation, Science and Practice". CLOSA, 2021. P. 214-218.

12. State. Right. Economics /Resp. ed. Chkhikvadze V.M. Moscow, 1970. 488 p.

For citation: Mitskaya E.V. Reflecting on achieving the effectiveness of regulatory legal acts: article // Legal thought. 2021. No. 4 (124). P. 82-87.

DOI: 10.47905 / MATGIP.2021.124.4.006

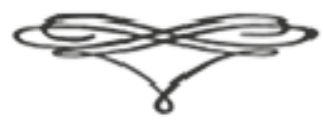




\title{
Информацнонные права \\ в сферЕ ЗАравооХранення
}

\section{а.ब. Петруннна}

\begin{abstract}
Аннотация. В статье рассматривается возможность обеспечения права человека на получение информации о способе и ресурсах мечения. Проанализирована возможность реализации такого права одновременно с обеспечением защиты прав на интелмектуальную собственность, разработанной в медицинских целях.
\end{abstract}

Ключевые слова: информация, право на получение информации, медицинская помощь, биомедицинские продукты, срок экскАюзивности.

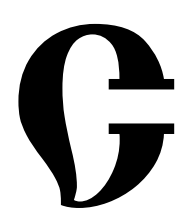

татья 41 Конституции Российской Федерации закрепляет право каждого на охрану здоровья и медицинскую помощь $[1,6]$. Cегодня варианты оказания такой помощи достаточно разнообразны: первичная медико-санитарная помощь, специализированная, в том числе высокотехнологичная, медицинская помощь, скорая, в том числе скорая специализированная, медицинская помощь, памлиативная медицинская помощь [3, ст. 32].

Конституция Российской Федерации закрепляет защиту права на информацию. Так органы государственной власти и органы местного самоуправления, их должностные мица обязаны обеспечить каждому возможность ознакомления с документами и материалами, непосредственно затрагивающими его права и свободы, если иное не предусмотрено законом [1, ст. 24]. Однако механизм реализации этого положения достаточно сложен, особенно в контексте использования биомедицинских продуктов и мекарственных препаратов.

Федеральный закон "Об информации, информационных технологиях и о защите информации" содержит открытый перечень информации, доступ к которой может быть ограничен. Исходя из приведенных в нем поможений, можно предположить, что имеются в виду сведения, составмяющие государственную, налоговую, врачебную и другие тайны, персональные данные, сведения, связанные с выполнением служебных функций на государственной гражданской службе и иные сведения [5]. Перечень сведений, составцяющих государственную тайну, содержится в ст. 5

* Петрунина Алена Анатольевна, студентка Самарского национального исследовательского университета им. академика С. П. Королева. E-mail: petrunina1303@mail.ru

Научный руководитель - Якунина Анастасия Владимировна, ассистент кафедры государственного и административного права Самарского национального исследовательского университета им. академика С. П. Коромева. 
Закона Российской Федерации "О государственной тайне». В него, прежде всего, вкАючены сведения в военной области, сведения в области экономики, науки и техники, связанные с оборонным комплексом [2]. Очевидно, что сведения о докАинических и кАинических испытаниях продуктов медицинского назначения не входят в сферу распространения действия положений данной статьи.

Правовой режим такой информации законодательно не закреплен, но анализируя меры по охране такой информации можно прийти к выводу, что ближе всего режим ноу-хау, применяемый к сведениям, составляющим коммерческую тайну. К сведениям, составцяющим коммерческую тайну, относится ограничений, содержащихся в статье 5 Федерального закона "О коммерческой тайне" [4]. Секретом производства не могут быть признаны сведения, обязательность раскрытия которых мибо недопустимость ограничения доступа к которым установлена законом или иным правовым актом. При этом, перечень сведений, доступ к которым не может быть ограничен, определен также Федеральным законом “Об информации, информационных технологиях и о защите информации" и так же явцяется открытым [5]. В связи с этим вопрос о том, являются ми сведения о докАинических и кАинических испытаниях биомедицинского клеточного продукта с ограниченным доступом остается открытым.

Представляется возможным применение режима, схожего с режимом защиты результатов доклинических и клинических испытаний мекарственного препарата. В 2010 году был установлен срок эксклюзивности данных мекарственного препарата, составляющий на сегодняшний день 6 мет. В течение этого срока действует запрет на использование в коммерческих цемях информации о результатах доклинических и клинических исследова-

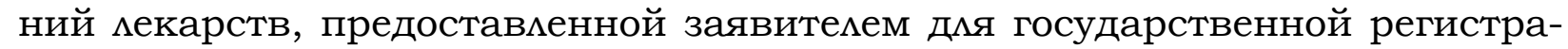
ции мекарственного препарата, без его согмасия.

Эксклюзивность данных представляет собой право производителя оригинального мекарственного средства в течение определенного периода времени использовать данные проведенных им исследований только в собственных целях, в том числе дия компенсации затрат на разработку и вывод на рынок нового мекарственного препарата. Это право реализуется путем запрета регуляторным органам принимать от других производителей заявки на регистрацию воспроизведенных мекарственных средств, содержащих ссылки на результаты доклинических и клинических исследований оригинального препарата [9].

При этом в течение срока эксклюзивности данных разрешается проведение исследований препарата научными организациями. Изменение ряда статей Гражданского кодекса РФ привело к тому, что право на проведение испытаний и исследований получили образовательные и научные организации, чьи разработки и результаты изучения потенциально приведут к улучшению качества продуктов.

Верховным Судом Российской Федерации сделан вывод о том, что запрет на разглашение и использование данных клинических исследований распространяется не на Аюбую информацию о проведенных доклини- 
ческих и клинических исследованиях оригинального мекарственного препарата. Данный запрет не касается информации, опубликованной в специализированных печатных изданиях. Использование такой информации признается, по мнению Верховного Суда Российской Федерации, законным [7].

Стоит отметить, что период эксклюзивности данных, применяемый в отношении мекарственных препаратов, был введен с целью оградить производителя референтного препарата от использования сведений о доклинических и клинических испытаниях от коммерческого оборота. Однако в контексте права человека на получение информации о способе и ресурсах мечения, представляется необходимым предоставцение не только досье, но и информации об испытаниях, проведенных с препаратом.

В связи с этим, на наш взгляд, необходимо создание реестра биомедицинских продуктов. Применяя аналогию с мекарственными средствами, можно говорить об эффективности такого инструмента. Идея создания подобного реестра мекарственных средств с целью усовершенствования системы государственной регистраиии лекарственных препаратов и обеспечения возможности проверки и выявления прав третьих лии на действуюшие вешества, используемые в заявленных $\kappa$ регистраиии воспроизведенных препаратах была высказана руководителем Федеральной службы по интемлектуальной собственности Г.П. Ивлиевым. По его мнению, такой реестр должен был содержать сведения об относяиихся $\kappa$ действуюшему вешеству зашишенных патентом РФ изобретениях, используемых в референтных лекарственных препаратах, номера соответствуюиих патентов и сроки их действия, а также сведения о патентообладателях, которые будут вноситься в Реестр по заявлениям правообладателей на основании представленных подтверждаюших документов после согласования с Роспатентом [8]. На сегодняшний день сушествует перечень взаимоза-

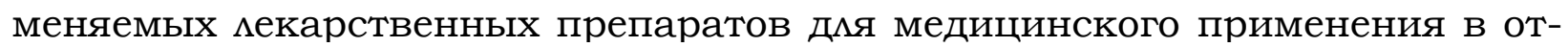
ношении референтных мекарственных препаратов дмя медицинского применения и воспроизведенных мекарственных препаратов для медицинского применения, в регистрационных досье на которые имеются результаты исследований биоэквивалентности или исследований терапевтической эквивалентности по отношению к референтному мекарственному препарату, сформированный Министерством здравоохранения. Представляется цемесообразным создание подобного перечня и с биомедицинскими препаратами, в котором бы отражались сведения о названии, применении, технологии изготовления, результатах доклинических и клинических испытаниях, о проведенных дополнительных исследованиях, проведенными научными и/или образовательными организациями, сведения о патентах и другие сведения.

В целях обеспечения защиты в период срока эксклюзивности доступ к такому реестру может быть обеспечен путем выдачи могина и пароля в медицинском или научном учреждении, в целях ознакомления с полной информации о возможности применения биомедицинского продукта в $е$ чебных, научных или образовательных целях. Такой реестр представляет под собой базу данных, авторские и смежные права которого принадме- 
жали бы Министерству здравоохранения, а согласие на включение препарата в этот реестр подавалось бы разработчиком вместе с пакетом документов на государственную регистрацию продукта. При этом при истечении срока эксклюзивности или по истечению срока патентной охраны, информация о проведенных испытаниях должна переходить в открытый доступ.

Таким образом, необходимо совершенствование системы доступа к данным об исследованиях биомедицинского препарата в целях обеспечения права человека на получение информации о способе и ресурсах мечения и контроле за реализацией права на охрану здоровья и медицинскую помощь. При этом разрабатываемый механизм обеспечения этих прав не должен нарушать патентные права создателей продукта. Создание предлагаемой базы данных осложнено возможным взмомом базы данных с применением кибератак или использование подложных сведений в целях получения могина и пароля для входа в базу данных. Поэтому необходима дальнейшая проработка этого вопроса как с гражданско-правовой стороны, так и со стороны уголовной и административной ответственности за нарушение правиц использования базы данных.

\section{Библиографический список}

1. Конституция Российской Федерации: принята всенародным голосование 12.12.1993 г. (ред. от 14.03.2020) // www.consultant.ru

2. Закон Российской Федерации от 21.07.1993 № 5485-1 «О государственной тайне" (ред. от 11.06.2021) // www.consultant.ru

3. Федеральный закон Российской Федерации от 21 ноября 2011 г. № 323-Ф3 “Об основах охраны здоровья граждан в Российской Федерации" (ред. от 13.07.2021) // www.consultant.ru

4. Федеральный закон Российской Федерации от 29 июля 2004 г. № 98-Ф3 "О коммерческой тайне» (ред. от 09.03.2021) // www.consultant.ru

5. Федеральный закон "Об информации, информационных технологиях и о защите информации" от 27.07.2006 № 149-Ф3 (ред. от 02.07.2021) // www. consultant.ru

6. Комментарий к Конституции Российской Федерации / С. А. Комаров [и др.]; под ред. С.А. Комарова. - 3-е изд., перераб. и доп. - М.: Издательство Юрайт, 2019. - 333 с. - (Серия: Профессиональные комментарии).

7. Опредемение Верховного Суда Российской Федерации № 305-ЭС16-2399 от 26.05.2016 / /URL: http:/ / www.vsrf.ru/stor_pdf_ec.php?id=1442412

8. Защитит единый реестр. Дия четкого соблюдения прав патентообладатемей нужны изменения в законе "Об обращении мекарственных средств" // URL: https://rospatent.gov.ru/ru/news/dlia-zashchity-patentoobla- datelej-nuzhno-meniatzakon-ob-obrashchenii-lekarstv

9. Всем странам ЕАЭС необходимо установить период эксклюзивности данныx //URL: https://rg.ru/2019/06/04/vsem-stranam-eaes-neobhodimo-usta- novit period-ekskliuzivnosti-dannyh.html

Дия цитирования: Петрунина А.А. Информационные права в сфере здравоохранения: статья // Юридическая мысль. - 2021. - No. 4 (124). - Р. 88-91.

DOI: 10.47905 / MATGIP.2021.124.4.007 


\section{Health information rights}

\section{Alena A. Petrunina*}

Annotation. The article discusses the possibility of ensuring the human right to receive information about the method and resources of treatment. The possibility of exercising such a right at the same time ensuring the protection of intellectual property rights developed for medical purposes is analyzed.

Key words: information, the right to information, medical care, biomedical products, data exclusivity.

Article 41 of the Constitution of the Russian Federation enshrines the right of everyone to health care and medical care [1, 6]. Today, the options for providing such care are quite diverse: primary health care, specialized, including high-tech, medical care, ambulance, including specialized emergency, medical care, palliative care [3, Art. 32].

The Constitution of the Russian Federation enshrines the protection of the right to information. So public authorities and local governments, their officials are obliged to provide everyone with the opportunity to familiarize themselves with documents and materials directly affecting his rights and freedoms, unless otherwise provided by law [1, Art. 24]. However, the mechanism for implementing this provision is rather complicated, especially in the context of the use of biomedical products and drugs.

The Federal Law "On Information, Information Technologies and Information Protection" contains an open list of information, access to which may be restricted. Based on the provisions given in it, it can be assumed that this means information constituting state, tax, medical and other secrets, personal data, information related to the performance of official functions in the civil service and other information [5]. The list of information constituting a state secret is contained in Art. 5 of the Law of the Russian Federation "On State Secrets". It includes, first of all, information in the military field, information in the field of economics, science and technology related to the defense complex [2]. Obviously, information about preclinical and clinical trials of medical products is not included in the scope of the provisions of this article.

The legal regime of such information is not legally enshrined, but analyzing the measures for the protection of such information, one can come to the conclusion that the closest is the know-how regime applied to information constituting a commercial secret. Information constituting a commercial secret includes any information at the discretion of its rightholder, subject to the restrictions contained in Article 5 of the Federal Law "On Commercial Secrets" [4]. Information, the disclosure of which is obligatory or the inadmissibility of restricting access to which is established by law or other legal act, cannot be recognized as a secret of production. At the same time, the lists of information,

*Petrunina Alena Anatolyevna, student of the Samara National Research University. Academician S. P. Korolev. E-mail: petrunina1303@mail.ru

Scientific adviser - Yakunina Anastasia Vladimirovna, Assistant of the Department of State and Administrative Law, Samara National Research University named after Academician S. P. Korolev. 
access to which cannot be limited, is also determined by the Federal Law "On Information, Information Technologies and Information Protection" and is also open [5]. In this regard, the question of whether the information on preclinical and clinical trials of a biomedical cell product with limited access remains open.

It seems possible to use a regime similar to the regime for protecting the results of preclinical and clinical trials of a medicinal product. In 2010, the exclusivity period for these medicinal products was set, which is currently 6 years. During this period, there is a ban on the use for commercial purposes of information on the results of preclinical and clinical trials of drugs provided by the applicant for state registration of the drug without his consent.

Data exclusivity is the right of the manufacturer of the original medicinal product for a certain period of time to use the data of the studies conducted by him only for his own purposes, including to compensating for the costs of developing and launching a new medicinal product on the market. This right is exercised by prohibiting regulatory authorities from accepting applications from other manufacturers for the registration of generic drugs containing references to the results of preclinical and clinical studies of the original drug [9].

At the same time, during the data exclusivity period, research of the drug by scientific organizations is allowed. Changes in a number of articles of the Civil Code of the Russian Federation led to the fact that educational and scientific organizations received the right to conduct tests and research, whose developments and research results will potentially lead to an improvement in the quality of products.

The Supreme Court of the Russian Federation concluded that the prohibition on the disclosure and use of clinical trial data does not apply to any information about preclinical and clinical trials of the original medicinal product. This prohibition does not apply to information published in specialized print media. The use of such information is recognized, in the opinion of the Supreme Court of the Russian Federation, lawful [7].

It is worth noting that the data exclusivity period applied to medicinal products was introduced in order to prevent the manufacturer of the reference product from using information on preclinical and clinical trials from commercial circulation. However, in the context of the human right to receive information about the method and resources of treatment, it seems necessary to provide not only the dossier, but also information about the trials carried out with the drug.

In this regard, in our opinion, it is necessary to create a register of biomedical products. Using the analogy with drugs, we can talk about the effectiveness of such a tool. The idea of creating such a register of medicinal products in order to improve the system of state registration of medicinal products and to ensure the possibility of checking and revealing the rights of third parties to active substances used in reproduced medications declared for registration was expressed by the head of the Federal Service for Intellectual Property G.P. Ivliev. In his opinion, such a register should have contained information about the inventions protected by the RF patent, related to the active substance, used in reference medicinal products, the numbers of the corresponding patents and their validity periods, as well as information about the patent holders, which will be entered into the Register on the basis of the applications 
of the rightholders on the basis of submitted supporting documents after agreement with Rospatent [8]. To date, there is a list of interchangeable drugs for medical use in relation to reference drugs for medical use and generic drugs for medical use, in the registration dossiers for which there are the results of bioequivalence studies or studies of therapeutic equivalence in relation to the reference drug, formed by the Ministry of Health ... It seems advisable to create a similar list with biomedical drugs, which would reflect information about the name, application, manufacturing technology, results of preclinical and clinical trials, additional studies conducted by scientific and / or educational organizations, information about patents and other information.

In order to ensure protection during the period of exclusivity, access to such a register can be provided by issuing a login and password in a medical or scientific institution, in order to get acquainted with full information about the possibility of using a biomedical product for medical, scientific or educational purposes. Such a register is a database, the copyright and related rights of which would belong to the Ministry of Health, and consent to the inclusion of a drug in this register would be submitted by the developer along with a package of documents for state registration of the product. At the same time, upon expiration of the exclusivity period or upon the expiration of the patent protection period, information about the tests performed should be made publicly available.

Thus, it is necessary to improve the system of access to data on research of a biomedical product in order to ensure the human right to receive information on the method and resources of treatment and to monitor the realization of the right to health care and medical care. At the same time, the developed mechanism for ensuring these rights should not violate the patent rights of the creators of the product. The creation of the proposed database is complicated by the possible hacking of the database using cyber attacks or the use of false information in order to obtain a username and password to enter the database. Therefore, further elaboration of this issue is necessary both from the civil law side and from the side of criminal and administrative responsibility for violation of the rules for using the database.

\section{Bibliographic list}

1. The Constitution of the Russian Federation: adopted by a popular vote on 12.12.1993 (as revised on 14.03.2020) // www.consultant.ru

2. Law of the Russian Federation dated July 21, 1993 No. 5485-1 "On state secrets" (as amended on June 11, 2021) // www.consultant.ru

3. Federal Law of the Russian Federation of November 21, 2011 No. 323-FZ "On the Fundamentals of Health Protection of Citizens in the Russian Federation" (as amended on July 13, 2021) // www.consultant.ru

4. Federal Law of the Russian Federation of July 29, 2004 No. 98-FZ "On Commercial Secrets" (as amended on 03/09/2021) // www.consultant.ru

5. Federal Law "On Information, Information Technologies and Information Protection" dated July 27, 2006 No. 149-FZ (as amended on July 2, 2021) // www. consultant.ru

6. Commentary on the Constitution of the Russian Federation / S. A. Komarov [and others]; ed. S.A. Komarov. 3rd ed., rev. and add. Moscow: Yurayt Publishing House, 2019. 333 p. (Series: Professional Commentary). 
7. Determination of the Supreme Court of the Russian Federation No. 305ES16-2399 dated 05/26/2016 // URL: http://www.vsrf.ru/stor_pdf_ec.php?id= 1442412

8. Protect a single register. For clear observance of the rights of patent holders, changes are needed in the Law "On the Circulation of Medicines" // URL: https:// rospatent.gov.ru/ru/news/ dlia-zashchity-patentoobla-datelej-nuzhno-meniat-zakonob-obrashchenii -lekarstv

9. All EAEU countries need to set the data exclusivity period // URL: https:// rg.ru/2019/06/04/ vsem-stranam-eaes-neobhodimo-usta-novit-period-ekskliu ivnosti-dannyh.html

For citation: Petrunina A.A. Reflecting on achieving the effectiveness of regulatory legal acts: article // Legal thought. 2021. No. 4 (124). P. 92-95.

DOI: 10.47905/ MATGIP.2021.124.4.007

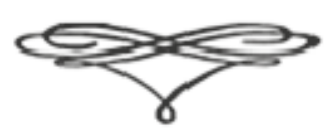




\title{
КорруПцня КаК провлема на ПуТТ Устойчнвого развнтня человечества в XXI веке
}

\section{Г.व. Прокоповнч*}

\begin{abstract}
Аннотация. В статье исследуются вопросы противодействия коррупции в ракурсе реализации целей устойчивого развития; проводится анализ недостатков законодательства о противодействии коррупции; вносятся предложения по его усовершенствованию.
\end{abstract}

К^ючевые слова: коррупция, законодательство о противодействии коррупции, устойчивое развитие, коррупционные преступления.

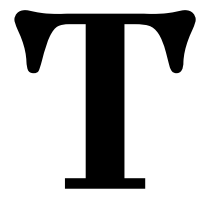

ермину "устойчивое развитие» вот уже бомее тридцати мет. Его используют в различных документах, как правицо, программных. Речь идёт не только о международных, но также и о национальных, региональных и о корпоративных актах. Изначально указанный термин домжен бым в экономической теории показывать исторические исследования, связанные с закономерностями эвомюции сельского хозяйства и устойчивого развития производительных сил, но политико-институциональные аспекты также не остались без внимания.

Устойчивое развитие предполагает наличие определённых целей, которые направлены, в том числе, на искоренение нищеты, повышение качества жизни и улучшение перспектив дмя всех зумевается принятие мер, ориентированных на сохранение стабильности социальных и культурных систем.

В апреле 2015 года в г. Панама на Пятой сессии Конференции государств-участников Конвенции Организации Объединенных Наций против коррупции исполнитемьный директор Управления Организации Объединенных Наций по наркотикам и преступности (далее Управление) Юрий Федотов в своём выступлении отметил, что "коррупция является вором экономического и социального развития; она ворует возможности простых мюдей к прогрессу и процветанию" [4]. Также он отметиц, что "при активном участии Организации Объединённых Наций, государств-чценов и гражданского общества, Управление активно борется с бедностью, оказывая содействие здравоохранению и развитию. Однако эффективность такой борьбы снижается благодаря наркотикам, преступности, коррупции и терроризму. Именно эти фракторы нарушают права человека, которые замед-

* Прокопович Галина Алексеевна, профессор кафедры теории государства и права им. Г.В. Мальцева Института права и национальной безопасности Российской академии народного хозяйства и государственной скужбы при Президенте Российской Федерации, доктор юридических наук, доцент. E-mail: galina-prokopovich@yandex.ru 
Аяют социально-экономическое развитие государств и ограничивают общепризнанные права чемовека. Эти преступления процветают именно там, где верховенство права ослабело, а уголовное правосудие оказалось малоэффрективным" [4].

О реализации принципа верховенства права необходимо говорить в ракурсе тех проблем, которые мешают этому процессу: нет согласованности в структурах и институтах государства или они не всегда действенны, а права человека не всегда очерчиваются правовыми рамками. Согласно Конституции РФ мы все, как граждане государства, имеем равные права и всем нам одинаково доступны государственные ускуги, информация и правосудие [1]. При этом принцип верховенства права домжен составцять основу всех законодательных актов РФ, что послужит гарантией устойчивого развития государства, которое предполагает, в том числе, и борьбу с коррупцией.

Коррупция является одним из самых серьёзных препятствий на пути устойчивого развития. Она негативно сказывается на политических, экономических и социальных сферах, порождая нестабимьность. Если ей не противодействовать, то коррупция сдемает невыгодными прямые иностранные инвестиции, что пагубно скажется на предпринимательстве, а впоследствии и на всей экономике государства. А если говорить о коррупции в цемом, то нельзя отрицать того факта, что её разрушительное действие пронизывает все слои общества, невзирая на положение в нём каждого граждани-

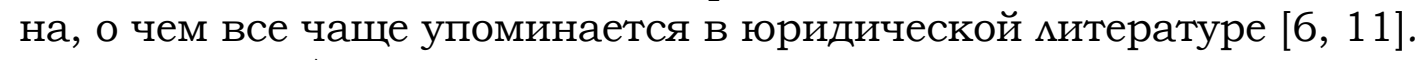

Но наиболее тяжело приходится малоимущему населению, поскольку коррупция сама и создаёт эту бедность. "Бедность и нищета - это недоедание, социальная изоляция и дискриминация, ограниченный доступ к образованию и к другим основным социальным услугам, а также невозможность участия в принятии решений" [9]. Борьба с этими социальными феноменами заявлена целью № 1 среди 17 целей устойчивого развития человечества. И эта борьба тесно связана с процессами искоренения коррупции, которая зачастую проявляется в форме незаконного распределения

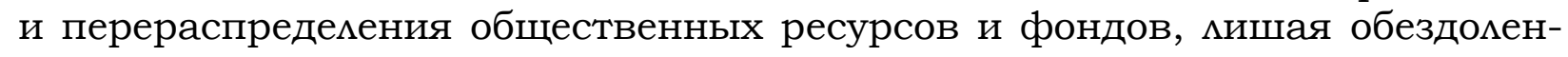
ные слои возможности участвовать в различных социальных проектах.

«Международное антикоррупционное движение Transparency International опубликовало Индекс восприятия коррупции (Corruption Perceptions Index, CPI) за 2020 год. В этот раз Россия набрала 30 бамлов из 100 и заняла 129 место из 180. Столько же набрали Азербайджан, Габон, Малави и Мами" [10]. Такое значение Индекса восприятия коррупции свидетельствует о том, что коррупция в России высокая. И за последние два года мы сдали две позиции.

Закон о противодействии коррупции есть, а результатов нет. О низком качестве основного закона о противодействии коррупции говорияось ещё тогда, когда он только обсуждался [7]. По мнению большинства учёных проект закона носил преимущественно декларативный характер, обсуждение его практически не проводимось, да и времена тогда были такие, когда считалось, что коррупция - это порождение капиталистического общества и нашей проблемой не является. Если взглянуть на недостатки Федерально- 
го закона от 25 декабря 2008 г. № 273-Ф3 "О противодействии коррупции" [5] с позиций сегодняшнего времени, то сразу бросается в глаза его слабая криминологическая обоснованность и невысокая юридическая техника.

Так, следовало бы чётко обозначить наиболее общественно опасные правонарушения, относящиеся к коррупционным, а для этого соотнести их с теми, что прописаны в принятых и ратифицированных Россией международно-правовых актах. Правда, при этом появится другая проблема проблема международной имплементации стандартов и средств борьбы с коррупцией. Но, возможно, нам станет понятен перечень коррупционных правонарушений, подпадающих под состав "зцоупотребление служебным положением", неизвестный уголовному закону, поскольку в ст. 285 УК РФ речь идет о "змоупотреблении домжностными поцномочиями".

Если мы откроем международно-правовые акты, ратифицированные Российской Федерацией, то увидим, что они прямо указывают на уголовную ответственность за незаконное обогащение. Речь идёт о ст. 20 Конвенции ООН против коррупции, принятой Генеральной Ассамблеей на проходившей 58-й сессии. Но наше законодатецьство знает только неосновательное обогащение, регламентированное ст. 1102 ГК РФ. Об уголовной ответственности за подобное деяние не может быть и речи. Тем не менее, положения главы 30 УК РФ позволяют вести борьбу с коррупцией почти по всем составам данного типа преступлений - змоупотребление должностными полномочиями, нецелевое расходование бюджетных средств, превышение должностных полномочий и так далее [2]. Если множество этих статей объединить в одну, то сразу же возникнут новые вопросы: что понимать под значительным увеличением активов и что вкладывать в содержание понятия "актив", а также в каких случаях следует говорить о невозможности чиновника разумным образом обосновать свое обогащение? [8].

Причины назначения дмя чиновников основного вида наказания за многие коррупционные преступления в виде штрафа остаются непонятными. Речь идёт о ст. ст. 285, 285.1, 285.2, 286, 290 УК РФ и др. [2]. Возможно, законодательная техника подвела: расширили специальные нормы об уголовной ответственности, но при этом не повысици их санкции по сравнению с общими нормами. А в итоге преступники понесут менее суровое наказание, чем то, которое было установлено до принятия специальной нормы. В социальном же плане это приведёт к нарушению принципа справедливости в праве.

Важную роль в борьбе с коррупцией играет и устранение комлизий и противоречий действующего законодательства Российской Федерации. Например, гражданское законодательство частично мегализует коррупционное поведение чиновника. Речь идет о п. 3 ст. 575 ГК РФ, согласно которому "не допускается дарение, за исключением обычных подарков, стоимость которых не превышает трех тысяч рублей, государственным служащим и служащим органов муниципальных образований в связи с их должностным поможением или в связи с исполнением ими служебных обязанностей" [3].

Иными словами, гражданское законодательство допускает такое дарение, а вот нормы уголовного законодательства, предусматривающие ответственность за получение и дачу взятки, в качестве предмета взяток при- 
знают кроме денег и ценных бумаг также имущество и имущественную выгоду, при этом их стоимость никакого значения дия привлечения к уголовной ответственности за взяточничество не имеет. Возникает вопрос о критериях отграничения подарка от взятки.

В заключение хотелось бы отметить, что действующее законодательство в сфере противодействия коррупции всё еще нуждается в дальнейшем совершенствовании. И пока мы всерьёз не займёмся решением проблемных вопросов борьбы с коррупцией - это будет не борьба, а её имитация.

\section{Бибинографический список}

Конституция Российской Федерации: принята всенародным голосование 12.12.1993 г. (ред. от 14.03.2020) // www.consultant.ru; Комментарий к Конституции Российской Федерации. 3-е изд., испр. и доп. // Под ред. проф. С.А. Комарова. - М.: Изд-во "Юрайт", 2020. - 333 с.

2. Угомовный Кодекс Российской Федерации // //http://publication.pravo. gov.ru/Document/View/0001202004010073?index=0\&rangeSize=1

3. "Гражданский кодекс Российской Федерации (часть первая)" от 30.11.1994 № 51-Ф3 // "Собрание законодательства РФ», 05.12.1994, N 32, ст. 3301.

4. Тринадцатый Конгресс Организации Объединённых наций по предупреждению преступности и угомовному правосудию // URL: https://www.un.org/ru/ events/crimecongress2015/corruption.shtml

5. Федерамьный закон от 25 декабря 2008 г. № 273-Ф3 «О противодействии коррупции" //www.consultant.ru

6. Коррупция и меры её ограничения: теоретико-правовое исследование [Текст] : монография / Прокопович Г.А., Артемьев А.Б.; Московский университет им. С. Ю. Витте. М., 2017. - 283 с.; Артемъев А.Б., Жаксыльк М.Ж., Комаров С.А. Коррупция и произвол: категории в теории государства и права: статья // Сборник материалов научно-теоретической конференции 6-8 декабря "XI Ауэзовские чтения». - Шымкент: Изд-во ЮКГУ, 2012; Артемъев А.Б., Комаров С.А. Коррупция как научная категория: Статья // Право и государство: теория и практика. 2012. - № 4. - С. 6-10; Артемъев А.Б., Комаров С.А. Коррупция как объективное явление: концепция исследования //Юридическая мысль. - 2010. - № 4. - С. 1419 и др.

7. Прокопович Г.А. Юридическая ответственность в российском праве: Теоретический аспект : автореф. дис. ... канд. юрид. наук. - М., 2003. - 21 с.

8. Пути совершенствования юридической ответственности в публичном и частном праве: монография / Г.А. Прокопович. - М.: МЭАИ, 2009. - 372 с.

9. ЦУР № 1 - Аиквидация нищеты // URL: http://sdg.openshkola.org/goal1

10. Россия в Индексе восприятия коррупции - 2020: 30 бамлов и 129 место // URL: http:// transparency.org.ruı...indeks...korruptsii...v...2020...129...

11. Гуринович А.Г. Организационно-правовой механизм увольнения государственных гражданских служащих в связи с утратой доверия за коррупционные правонарушения // Право. Журнал Высшей школы экономики. 2013. № 3. С. 61-86.

Дия цитирования: Прокопович Г.А. Коррупция как проблема на пути устойчивого развития человечества в XXI веке: статья // Юридическая мысль. - 2021. - No. 4 (124). P. 96-99.

DOI: 10.47905 / MATGIP.2021.124.4.008 


\title{
Corruption as a problem for sustainable human development in the twenty-first century
}

\section{Galina A. Prokopovich*}

\begin{abstract}
Annotation. The article explores anti-corruption issues in terms of achieving sustainable development goals; analysis of shortcomings of the anti-corruption law; proposals for its improvement is being made.
\end{abstract}

Key words: corruption, anti-corruption legislation, sustainable development, corruption crimes.

The term "sustainable development" has been around for over thirty years. It is used in various documents, usually software. We are talking not only about international, but also about national, regional and corporate acts. Initially, this term was supposed in economic theory to show historical research related to the laws of the evolution of agriculture and the sustainable development of productive forces, but the political and institutional aspects also did not go unnoticed.

Sustainable development presupposes specific goals that are aimed, among other things, at eradicating poverty, improving the quality of life and improving the prospects for all people around the world. This implies the adoption of measures aimed at maintaining the stability of social and cultural systems.

In April 2015 in Panama at the Fifth Session of the Conference of the States Parties to the United Nations Convention against Corruption, the Executive Director of the United Nations Office on Drugs and Crime (hereinafter the Office) Yuri Fedotov noted in his speech that "corruption is a thief of economic and social development; it steals the opportunities of ordinary people to progress and prosperity" [4]. He also noted that "with the active involvement of the United Nations, Member States and civil society, the Office is actively fighting poverty by promoting health and development. However, the effectiveness of such a struggle is diminished by drugs, crime, corruption and terrorism. It is these factors that violate human rights that slow down the socio-economic development of states and restrict universally recognized human rights. These crimes flourish precisely where the rule of law has weakened and criminal justice has proven ineffective" [4].

It is necessary to speak about the implementation of the principle of the rule of law from the perspective of those problems that hinder this process: there is no coherence in the structures and institutions of the state or they are not always effective, and human rights are not always delineated by a legal framework. According to the Constitution of the Russian Federation, we all, as citizens of the state, have equal rights and we all have the same access to state services, information and justice [1]. At the same time, the principle of the rule

* Prokopovich Galina Alekseevna, Professor of the Department of Theory of State and Law named after V.I. G.V. Maltseva of the Institute of Law and National Security of the Russian Academy of National Economy and Public Administration under the President of the Russian Federation, Doctor of Law, Associate Professor. E-mail: galina-prokopovich@yandex.ru 
of law should form the basis of all legislative acts of the Russian Federation, which will serve as a guarantee of sustainable development of the state, which implies, among other things, the fight against corruption.

Corruption is one of the greatest obstacles to sustainable development. It negatively affects the political, economic and social spheres, giving rise to instability. If it is not counteracted, then corruption will make foreign direct investment unprofitable, which will have a detrimental effect on entrepreneurship, and subsequently on the entire economy of the state. And if we talk about corruption in general, then one cannot deny the fact that its destructive effect permeates all strata of society, regardless of the position of every citizen in it, which is increasingly mentioned in the legal literature $[6,11]$.

But the worst is for the poor, since corruption itself creates this poverty. "Poverty and poverty is malnutrition, social exclusion and discrimination, limited access to education and other basic social services, as well as the inability to participate in decision-making" [9]. The fight against these social phenomena is declared as goal number 1 among the 17 goals of sustainable development of mankind. And this struggle is closely linked to the processes of eradicating corruption, which often manifests itself in the form of illegal distribution and redistribution of public resources and funds, depriving the disadvantaged strata of the opportunity to participate in various social projects.

"Transparency International has published the Corruption Perceptions Index (CPI) for 2020. This time Russia scored 30 points out of 100 and took 129th place out of 180. Azerbaijan, Gabon, Malawi and Mali scored the same number" [10]. This value of the Corruption Perceptions Index indicates that corruption in Russia is high. And over the past two years we have passed two positions.

There is an anti-corruption law, but no results. The low quality of the main anti-corruption law was mentioned even when it was just being discussed [7]. In the opinion of most scholars, the draft law was predominantly declarative, it was practically not discussed, and there were times when it was believed that corruption was a product of capitalist society and was not our problem. If we look at the shortcomings of the Federal Law of December 25, 2008, No. 273-FZ "On Combating Corruption" [5] from the standpoint of today, then its weak criminological substantiation and low legal technique are immediately striking.

So, it would be necessary to clearly identify the most socially dangerous offenses related to corruption, and for this to correlate them with those that are spelled out in the international legal acts adopted and ratified by Russia. True, in this case, another problem will appear - the problem of international implementation of standards and means of combating corruption. But, perhaps, we will understand the list of corruption offenses that fall under the "abuse of office", unknown to the criminal law, since in Art. 285 of the Criminal Code of the Russian Federation it is about "abuse of office".

If we open the international legal acts ratified by the Russian Federation, we will see that they directly indicate criminal liability for illegal enrichment. We are talking about Art. 20 of the UN Convention against Corruption, adopted by the General Assembly at the 58th session. But our legislation knows only 
unjust enrichment, regulated by Art. 1102 of the Civil Code of the Russian Federation. Criminal liability for such an act is out of the question. Nevertheless, the provisions of Chapter 30 of the Criminal Code of the Russian Federation make it possible to fight corruption in almost all elements of this type of crime - abuse of office, misappropriation of budget funds, abuse of office, and so on [2]. If many of these articles are combined into one, then new questions will immediately arise: what is meant by a significant increase in assets and what should be invested in the content of the concept of "asset", and also in what cases should we talk about the impossibility of an official to reasonably justify his enrichment? [8].

The reasons for the appointment of the main type of punishment for many corruption crimes in the form of a fine for officials remain unclear. We are talking about Art. Art. 285, 285.1, 285.2, 286, 290 of the Criminal Code of the Russian Federation and others [2]. Perhaps the legislative technique failed: they expanded the special norms on criminal liability, but at the same time did not increase their sanctions in comparison with the general norms. As a result, the criminals will suffer less severe punishment than that which was established before the adoption of the special rule. In social terms, this will lead to a violation of the principle of justice in law.

Elimination of collisions and contradictions of the current legislation of the Russian Federation also plays an important role in the fight against corruption. For example, civil legislation partially legalizes the corrupt behavior of an official. We are talking about clause 3 of Art. 575 of the Civil Code of the Russian Federation, according to which "donations are not allowed, with the exception of ordinary gifts, the value of which does not exceed three thousand rubles, to civil servants and employees of municipal bodies in connection with their official position or in connection with the performance of their official duties" [3].

In other words, civil law allows such donation, but the norms of criminal law, providing for liability for receiving and giving a bribe, recognize property and property benefits as the subject of bribes, in addition to money and securities, while their value is of no importance for criminal prosecution for bribery does not have. The question arises about the criteria for distinguishing a gift from a bribe.

In conclusion, I would like to note that the current anti-corruption legislation still needs further improvement. And until we seriously address the problematic issues of combating corruption, this will not be a fight, but an imitation of it.

\section{Bibliographic list}

1. The Constitution of the Russian Federation: adopted by a popular vote on 12.12.1993 (as revised on 14.03.2020) // www.consultant.ru; Commentary on the Constitution of the Russian Federation. 3rd ed., Rev. and add. // Ed. prof. S.A. Komarov. Moscow: Publishing house "Yurayt", 2020. 333 p.

2. The Criminal Code of the Russian Federation // http://http://publication. pravo.gov.ru /Document/View/0001202004010073?index=0\&rangeSize $=1$

3. "Civil Code of the Russian Federation (part one)" dated 30.11.1994 No. 51-FZ // "Collected Legislation of the Russian Federation", 05.12.1994, No. 32, art. 3301. 
4. Thirteenth United Nations Congress on Crime Prevention and Criminal Justice // URL: https://www.un.org/ru/events/crimecongress2015/corruption.shtml

5. Federal Law of December 25, 2008 No. 273-FZ "On Combating Corruption" // www.consultant.ru

6. Corruption and measures of its limitation: theoretical and legal research [Text]: monograph / Prokopovich GA, Artemiev AB; Moscow University S. Yu. Witte. Moscow, 2017. 283 p.; Artemiev A.B., Zhaksylyk M.Zh., Komarov S.A. Corruption and arbitrariness: categories in the theory of state and law: article // Collection of materials of the scientific-theoretical conference on December 6-8 "XI Auezov readings". Shymkent: Publishing house SKSU, 2012; Artemiev A.B., Komarov S.A. Corruption as a scientific category: Article // Law and state: theory and practice. 2012. No. 4. P. 610; Artemiev A.B., Komarov S.A. Corruption as an objective phenomenon: the concept of research // Legal thought. 2010. No. 4. P. 14-19 and others.

7. Prokopovich G.A. Legal responsibility in Russian law: Theoretical aspect: author. dis. ... cand. jurid. sciences. Moscow, 2003. 21 p.

8. Ways to improve legal responsibility in public and private law: monograph / G.A. Prokopovich. Moscow: MELI, 2009. 372 p.

9. SDG No. 1 - Eradicate poverty // URL: http://sdg.openshkola.org/goal1

10. Russia in the Corruption Perceptions Index - 2020: 30 points and 129th place / / URL: http: / / transparency.org.ru ... indeks... korruptsii... v... 2020 .. 129...

11. Gurinovich A.G. Organizational and legal mechanism for the dismissal of civil servants in connection with the loss of confidence for corruption offenses // Law. Journal of the Higher School of Economics. 2013. No. 3. P. 61-86.

For citation: Prokopovich G.A. Corruption as a problem on the path of sustainable development of mankind in the XXI century: article // Legal thought. 2021. No. 4 (124). P. 100103.

DOI: $10.47905 /$ MATGIP.2021.124.4.008

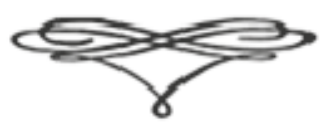




\title{
Теорня прннципов Рональда Дворкнна - третнй пүть в теорнн права?
}

\author{
К.Г. Прокофьев* \\ A.R. Иванов
}

\begin{abstract}
Аннотация. Развитие Р. Дворкиным традиционной для англосаксонской теоретико-правовой науки "модели правовых принципов", которую он в модифицированном им варианте противопоставцяет модеми "правовых правил" аналитической юриспруденции, позволяет ставить вопрос о "третьем пути" в теории права относительно учений естественного права и правового позитивизма. Однако такой вывод при всех возможных аргументах в его пользу выглядит преждевременным с учетом исторической многовариативности естественно-правовых модемей.

Кмючевые слова: Рональд Дворкин (Ronald Dworkin), аналитическая юриспруденция, правовой позитивизм, естественное право, теория принципов, мораль, право.
\end{abstract}

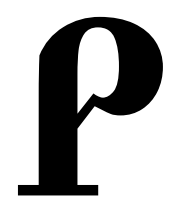

ональд Майльс Дворкин (1931 - 2013) признан одним из крупнейших англо-американских правоведов нашего времени с мировым именем [12, с. 23]. Известностью он во многом обязан многолетней дискуссии со своим учителем, основоположником аналитической юриспруденции, Г. Хартом. Эта дискуссия, помучившая в научной митературе особое название "Hart-Dworkin-Debatte" [6, c. 448; 12, с. 23], до настоящего времени продолжает находиться в центре внимания западной научной общественности.

В своей книге "О правах всерьез" Р. Дворкин пытается дать опредеменное понимание права в отличие от неопредеценного состояния обще-

* Прокофьев Константин Георгиевич, проректор Оренбургского государственного университета, кандидат юридических наук. E-mail: 775777@bk.ru

** Иванов Денис Владимирович, аспирант кафедры теории и истории государства и права Частного образовательного учреждения высшего образования «Юридический институт" (Санкт-Петербург). E-mail: deiv@rambler.ru

Научный руководитемь - Комаров Сергей Александрович, профессор кафедры теории государства и права Института права Башкирского государственного университета, научный руководитель ЧОУ ВО "Юридический институт" (Санкт-Петербург), президент МОО "Межрегиональная ассоциация теоретиков государства и права", доктор юридических наук, професcop. E-mail: SVKomarov2008@yandex.ru

Научный консультант - Масленников Дмитрий Владимирович, проректор по учебной работе, заведующий кафедрой общегуманитарных дисциплин Частного образовательного учреждения высшего образования "Юридический институт" (Санкт-Петербург), доктор фимософских наук, профессор. E-mail: dwm61@inbox.ru 
принятой политической позиции $[1$, с. 5]. Он резко критикует теорию, которую многие считают миберацьной, считая, что "эта теория была столь популярна и пользовалась столь большим влиянием, что я буду называть ее господствующей теорией права. Господствующая теория состоит из двух частей, которые, как настаивают ее сторонники, не зависят друг от друга. Первая ее часть - это теория о том, что есть право; если говорить не столь высокопарным языком, то это теория о необходимых и достаточных условиях истинности для суждений права. Эту теорию называют правовым позитивизмом, и, согласно ей, истинность суждений права определяется только фактами относительно норм, принятых особыми социальными институтами, и ничем иным. Вторая часть этой теории касается того, каким должно быть право и как должны действовать известные правовые институты. Эту теорию называют утилитаризмом, и, согласно ей, право и долг гражданина подчиняться закону при различных формах государственного устройства и при разцичных обстоятельствах; и теорию принуждения, правовые институты должны служить всеобщему благоденствию и ничему иному. Обе части господствующей теории права имеют своим источником фимософию Иеремии Бентама" [1, с. 5-6].

Теоретической основой дискуссии являются глубокие разногласия Р. Дворкина с аналитической юриспруденцией (он предпочитает более общий термин: "позитивизм"). В своей полемике Р.Дворкин сводит всю теоретическую модель правового позитивизма к опыту редукции юридического материала до уровня, так называемой "модели правим" [7, с. 192].

Согласно Р.Дворкину, эта модемь основана на отношениях по принципу "если - то». В части “если" описываются условия, которые должны иметь результатом определенные правовые следствия. В части "то" описываются, собственно, эти самые следствия. Такого рода подход Дворкин считает упрощенным, не позволяющим, во-первых, дедуцировать понятия прав и обязанностей мичности с учетом всех их нюансов [7, с. 196], а, вовторых, не позволяющим обосновать понятие права, основанного на судебном прецеденте [7, с. 197], что, безусловно, важно дия англосаксонского права. И наоборот: ссылаясь на реальный опыт судейской практики, Р. Дворкин указывает на невозможность обойтись при разрешении сложных дем в суде мишь позитивными "правимами", без учета всеобщих принципов права $[7$, с. 28].

В поисках альтернативы позитивистской "модеми правим" Дворкин предлагает вернуться к теории принципов, варианты который мы можем разглядеть уже в традиционной теории естественного права. Однако при этом он вносит в нее свои коррективы на стыке аналитической и феноменологической методологии, что дало возможность немецкому историку права Александру Хайнольду говорить о наметившемся в работах Р. Дворкина "третьем пути" в теории права - между теорией естественного права и юридическим позитивизмом [12, с. 46].

Р. Дворкин исходит из того, что юридический позитивизм мибо полностью отрицает всеобщие принципы права, как не имеющие прямых эмпирических аналогов, мибо оставляет их искцючительно в ведении юридической метафизики. Таким образом, речь идет, прежде всего, об уточнении 
содержания правовых принципов и о введении этого содержания в теоретический дискурс, возникающий в интертекстуальном пространстве анамитической и феноменологической правовой митературы. Само понятие

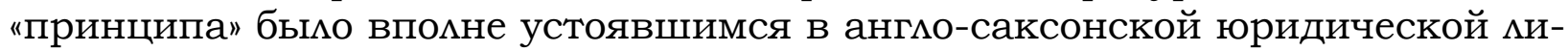
тературе понятием задолго до Р. Дворкина и понималось оно в качестве комплекса определяющих идей, стоящих "за спиной" правовых высказываний и текстов законодательных актов.

Основной вопрос теории правовых принципов составляла проблема, заключающаяся в том, какие принципы, взятые в качестве элементов социального порядка, могли бы иметь результатом своего вцияния на общество комплекс правых норм. Вкцад Р. Дворкина в решение этой проблемы видится в том, что он вводит ее в контекст вопроса об отношении морали и права. Упрощенной теории раннего позитивизма, согласно которой общие принципы, входящие в систему социального порядка, составляют моральный фундамент права, Дворкин противопоставцяет идею разцичия права и морали в ее радикальном варианте.

Позитивистской "модели правим" Р. Дворкин противопоставцяет свою концепцию "правовых принципов", которые он трактует как некоторый "масштаб" для правовых явлений [7, с. 197]. В работе "О правах всерьез" в русском переводе мы встречаем также следующий вариант трактовки ученым своей основной категории: "Чаще всего термин "принцип" я буду употреблять в самом общем смысле - как обозначающий всё множество тех стандартов, которые не являются нормами. Однако иногда, чтобы быть бомее точным, я буду проводить разцичие между принципами и стратегиями... "Принципом" я называю такой стандарт, который следует соблюдать не потому, что он способствует изменению или сохранению некоторой экономической, политической или социальной ситуации, а потому что он выражает некоторые моральные требования, будь то требования справедливости, честности и т.д." [1, с. 45].

При этом Р. Дворкин вовсе стремится подвергнуть позитивистскую "модемь правим" уничтожающей критике. Его усилия, скорее, направлены на то, чтобы их примирить, найти общие точки их соприкосновения. Это единство Р. Дворкин усматривает в общей телеологической природе правовых правиц и правовых принципов: и те, и другие базируются на отношении к цели. Эту цель Р. Дворкин определяет как нечто "должное".

Но в отношении к этой цели должного "правима" и "принципы" действуют по-разному. Применение правовых правиц в случае их противоречия друг другу требует искАючения одного из них из практики правоприменения в целом или же в данном конкретном случае. Напротив, всеобщие принципы в случае конкуренции друг с другом сохраняются сообществом, просто одни из них в процессе социально-правовой коммуникации выходят на передний план, а другие, наоборот, временно отступают, полностью сохраняя при этом свою ценность и возможность быть востребованными обществом в обозримом будущем.

В числе важнейших и высших принципов Р. Дворкин называет право на свободу, на жизнь и на стремление к счастью. Эти принципы, по мнению швейцарского историка правовых учений М. Зенна, Р. Дворкин воспринял 
из общепринятого толкования американской конституции [13, с. 157]. Однако, еще более основополагающим принципом Р. Дворкин считает принцип равенства, из которого непосредственно следуют принципы, указанные выше [2, с. 8-11]. Идею принципа равенства Р. Дворкин, утверждает М. Зенн, заимствовал у Дж. Ролза [13, с. 157]. Все эти принципы могут конкурировать между собой, противоречить друг другу, "поскольку право является постоянно развивающейся системой. Право живет не могикой, а опытом" [12, с. 31]. В этом случае, разумеется, невозможно говорить о значимости общих принципов права дмя реальной юридической практики.

При этом Р. Дворкин подчеркивал, что сама по себе правовая коммуникация, ранжирующая правовые правила, не может обеспечить реализацию правовых принципов. Наряду с динамикой коммуникации в праве необходима и статика Основного закона, фиксирующего связь изменчивого и всеобщего в праве. В противном случае правовая жизнь обречена на деградацию: "Дворкин утверждает, что за последние десять мет жизнь мюдей в Великобритании становилась все менее и менее свободной как следствие усиленных мер по борьбе расширяющих полномочия охранительных органов, а также повсеместной политической цензуры. По мнению Дворкина, это приводит к повсеместному попранию самых базовых прав человека и свидетельствует о необходимости принятия писаной конституции Европейским союзом" [5, с. 25].

Поэтому вступая в полемику с позитивистами и апемлируя к идее правового принципа, Р. Дворкин должен был объяснить, как «право может изменяться, оставаясь при этом неизменным. И как возможно дать два противоположных ответа на один и тот же вопрос, будучи правым в каждом из случаев" [5, с. 21]. Таким образом, вопрос о соотношении, с одной стороны, изменчивости в праве (в том числе и в исторической перспективе), и его абсолютных, вечных принципов, с другой стороны, является одним из постоянных вопросов в теории права.

Упоминавшаяся нами оценка А. Хайнольдом "теории принципов" Р. Дворкина как своего рода "третьего пути" в теории права основана на противопоставцении теории естественного права и позитивизма как "двух полюсов" в историческом развитии основ представлений о праве [12, с. 46]. Следуя этой могике, А. Хайномьд видит суть естественно-правовой теоретической модеми в дедукции принципов права из общих принципов морали, а суть позитивистской модеми - в эмпирическом обосновании норм права и норм морали из системы социальных отношений. В последнем варианте обоснования нормы права и нормы морали выступают относительно независимо друг от друга.

В такой интерпретации истории правовых учений, вариант, предможенный Р. Дворкиным, действительно представцяется альтернативным, поскольку он предлагает обоснование принципов морали и принципов права, хотя и разцичных по сути, однако, и не противопоставляемых друг другу, не противоречащих друг другу, не отдаменных друг от друга непреодолимой стеной.

Думаем, что с такой интерпретацией в целом можно согласиться, однако, нужно иметь в виду все многообразие и сложность историческо- 
го развития теории естественного права. Особенно в ее поздних вариантах, в тех вариантах, которые мы находим в немецкой классической фимософиии.

Так, в работе И.Г. Фихте "Основа естественного права согласно принципам наукоучения" мы видим опыт паралмельной и независимой дедукции морали и права из единого высшего основоположения [3, с. 74; 4, с. 53]. Тем не менее, нужно согласиться с тем, что в работах Р. Дворкина мы находим существенное развитие общетеоретических и методомогических начал современной западной науки о фундаментальных основах права.

\section{Бибциографический список}

1. Дворкин Р. О правах всерьез. М., 2004 / Пер. с англ.; Ред. $\Lambda$. Б. Макеева. - М.: "Российская политическая энциклопедия" (РОССПЭН), 2004. - 392 с.

2. Игнаткин О.Б. "Равенство в свободе»: принципы политической философии Рональда Дворкина. - М.: Издательский центр Российского государственного гуманитарного университета, 2008. - 201 с.

3. Масленников Д.В., Ревнова М.Б. Диалектика субъективного и объективного в обосновании права классиками немецкой философии // Юридическая мысль. - 2020. - № 3 (119). - С. 74-91.

4. Фихте И.Г. Основа естественного права согласно принципам наукоучения. - М.: "Канон+», 2014. - 391 с.

5. Чурносов И.М. Правовая концепция Рональда Дворкина: дисс. ... канд. юрид. наук. - М., 2014. - 254 с.

6. Barbosa L.F. Influence of Ethics in the Concept of Law: Actual Stage of the "Hart-Dworkin Debate" / / XXVI World Congress of Philosophy of Law and Social Philosophy. Belo Horizonte: Forum, 2013. P. 448-449.

7. Braun J. Rechtsphilosophie im 20. Jahrhundert. Die Rückkert der Gerechtigkeit. München: Verlag C.H. Beck, 2001.

8. Dworkin R. Is Democracy Possible Here? Principles For a New Political Debate. Princeton: Oxford, 2006.

9. Dworkin R. Justice for hedgehogs. - London: Belknap Press, 2011.

10. Dworkin R. Law's Empire. London: Fontana, 1986.

11. Dworkin R. Sovereign Virtue: The Theory and Practice of Equality. Cambridge, MA: Harvard University Press, 2000.

12. Heinold A. Die Prinzipientheorie bei Ronald Dworkin und Robert Alexy. Berlin: Duncker\&Humbolt, 2011.

13. Senn M. Rechts- und Gesellschaftsphilosopie. Historische Fundamente der europäischen, nordamerikanischen, indischen sowie chinesisch Rechts - und Gesellschaftsphilosophie. Eine Einführung mit Quellenmaterial. Zürich: Dike Verlag, 2012.

Дия цитирования: Прокофьев К.Г., Иванов Д.В. "Теория принципов" Рональда Дворкина - "третий путь" в теории права? // Юридическая мысль. - 2021. - № 4 (124). C. 104-108.

DOI: $10.47905 /$ MATGIP.2021.124.4.009 


\title{
Ronald Dworkin's Theory of Principles - "Third way" in the theory of law?
}

\section{Konstantin G. Prokofiev* Denis V. Ivanov**}

\begin{abstract}
Annotation. The development by R. Dworkin of the "model of legal principles" traditional for Anglo-Saxon theoretical and legal science, which he, in a modified version, opposes the model of "legal rules" of analytical jurisprudence, allows us to raise the question of the "third way" in the theory of law regarding the teachings of natural law and legal positivism ... However, such a conclusion, with all possible arguments in its favor, looks premature given the historical multivariance of natural law models.
\end{abstract}

Keywords: Ronald Dworkin, analytical jurisprudence, legal positivism, natural law, theory of principles, morality, law

Ronald Myles Dworkin (1931 - 2013) is recognized as one of the largest Anglo-American jurists of our time with a worldwide reputation [12, p. 23]. He owes much of his fame to many years of discussion with his teacher, the founder of analytical jurisprudence, G. Hart. This discussion, which has received a special name in the scientific literature "Hart-Dworkin-Debatte" [6, p. 448; 12, p. 23], until now continues to be in the center of attention of the Western scientific community.

In his book "On Rights Seriously" R. Dworkin tries to give a definite understanding of law, in contrast to the indefinite state of the generally accepted political position [1, p. 5]. He sharply criticizes a theory that many consider liberal, believing that "this theory was so popular and so influential that I will call it the mainstream theory of law. The prevailing theory has two parts, which, as its proponents insist, are independent of each other. The first part is the theory of what is right; if we speak in a less pompous language, then this is a theory about the necessary and sufficient conditions of truth for judgments of law. This theory is called legal positivism, and, according to it, the truth of the judgments of law is determined only by facts about the norms adopted by special social institutions, and nothing else. The second part of this theory concerns what law should be and how certain legal institutions should operate. This theory is called utilitarianism, and, according to it, the right and duty of a citizen to obey the law under various forms of government and under various circumstances; and the theory of coercion, legal institutions should serve the

* Prokofiev Konstantin Georgievich, Vice-Rector of Orenburg State University, Candidate of Law. E-mail: 775777@bk.ru

** Ivanov Denis Vladimirovich, post-graduate student of the Department of Theory and History of State and Law of the Private Educational Institution of Higher Education "Legal Institute" (St. Petersburg). E-mail: deiv@rambler.ru

Scientific adviser - Komarov Sergey Aleksandrovich, Professor of the Department of Theory of State and Law of the Institute of Law of the Bashkir State University, Scientific Director of the Private Educational Institution of Higher Education "Legal Institute" (St. Petersburg), President of the Interregional Association of Theorists of State and Law, Doctor of Law, Professor. E-mail: SVKomarov2008@yandex.ru 
general welfare and nothing else. Both parts of the dominant theory of law have as their source the philosophy of Jeremiah Bentham" [1, p. 5-6].

The theoretical basis of the discussion is R. Dworkin's deep disagreements with analytical jurisprudence (he prefers a more general term: "positivism"). In his polemics, R. Dworkin reduces the entire theoretical model of legal positivism to the experience of reducing legal material to the level of the socalled "model of rules" [7, p. 192].

According to R. Dworkin, this model is based on relationships according to the "if - then" principle. The "if" part describes the conditions that should result in certain legal consequences. The part "that" describes, in fact, these very consequences. Dworkin considers this kind of approach to be simplified, not allowing, firstly, to deduce the concepts of the rights and obligations of an individual, taking into account all their nuances [7, p. 196], and, secondly, does not allow to substantiate the concept of law based on judicial precedent [7, p. 197], which is certainly important for Anglo-Saxon law. And vice versa: referring to the real experience of judicial practice, R. Dworkin points out the impossibility of resolving complex cases in court only with positive "rules", without taking into account the universal principles of law [7, p. 28].

In search of an alternative to the positivist "model of rules", Dworkin proposes to return to the theory of principles, variants of which we can see already in the traditional theory of natural law. However, at the same time, he makes his own adjustments to it at the junction of analytical and phenomenological methodology, which made it possible for the German historian of law Alexander Heinold to talk about the "third way" outlined in the works of R. Dworkin in the theory of law - between the theory of natural law and legal positivism [12, p. 46].

R. Dworkin proceeds from the fact that legal positivism either completely denies the universal principles of law, as they do not have direct empirical analogues, or leaves them exclusively in the jurisdiction of legal metaphysics. Thus, we are talking primarily about the clarification of the content of legal principles and the introduction of this content into the theoretical discourse that arises in the intertextual space of analytical and phenomenological legal literature. The very concept of "principle" was a well-established concept in the Anglo-Saxon legal literature long before R. Dworkin and it was understood as a set of defining ideas behind legal statements and texts of legislative acts.

The main question of the theory of legal principles was the problem of which principles, taken as elements of the social order, could result in their influence on society as a set of legal norms. R. Dworkin's contribution to the solution of this problem is seen in the fact that he introduces it into the context of the question of the relationship between morality and law. To the simplified theory of early positivism, according to which the general principles that make up the system of social order constitute the moral foundation of law, Dworkin opposes the idea of the difference between law and morality in its radical version.

R. Dworkin opposes his concept of "legal principles" to the positivist "model of rules", which he interprets as a certain "scale" for legal phenomena [7, p. 197]. In the work "On Rights Seriously" in Russian translation, we also find the following version of the interpretation by scientists of their main category: "Most often I will use the term" principle "in the most general sense - as 
denoting the whole set of those standards that are not norms. However, sometimes, to be more precise, I will distinguish between principles and strategies ... I call a "principle" a standard that should be followed, not because it contributes to the change or maintenance of some economic, political or social situation, but because it expresses some moral requirements, be it the requirements of justice, honesty, etc." [1, p. 45].

At the same time, R. Dworkin strives to subject the positivist "model of rules" to destructive criticism. Rather, his efforts are aimed at reconciling them, finding common points of contact. R. Dworkin sees this unity in the general teleological nature of legal rules and legal principles: both are based on the attitude towards the goal. R. Dworkin defines this goal as something "due".

But in relation to this goal, proper "rules" and "principles" operate in different ways. The application of legal rules in the event of their conflict with each other requires the exclusion of one of them from the practice of law enforcement in general or in this particular case. On the contrary, in the event of competition with each other, the community retains general principles, just some of them in the process of social and legal communication come to the fore, while others, on the contrary, temporarily recede, while fully retaining their value and the ability to be in demand by society in the foreseeable future ...

Among the most important and supreme principles R. Dworkin names the right to freedom, to life and to the pursuit of happiness. These principles, according to the Swiss historian of legal doctrines M. Zenna, R. Dworkin took from the generally accepted interpretation of the American constitution [13, p. 157]. However, R. Dworkin considers the principle of equality to be an even more fundamental principle, from which the principles indicated above directly follow [2, p. 8-11]. According to M. Zenn, R. Dworkin borrowed the idea of the principle of equality from J. Rawls [13, p. 157]. All these principles can compete with each other; contradict each other, "since the law is a constantly evolving system. Law lives not by logic, but by experience" [12, p. 31]. In this case, of course, it is impossible to talk about the importance of general principles of law for real legal practice.

At the same time, R. Dworkin emphasized that legal communication in itself, ranking legal rules, cannot ensure the implementation of legal principles. Along with the dynamics of communication in law, the statics of the Basic Law is also necessary, which fixes the connection between the changeable and the universal in law. Otherwise, legal life is doomed to degradation: "Dworkin argues that over the past decade, people's lives in the UK have become less and less free as a result of intensified measures to combat empowering law enforcement agencies, as well as widespread political censorship. According to Dworkin, this leads to a widespread violation of the most basic human rights and indicates the need for the adoption of a written constitution by the European Union "[5, p. 25].

Therefore, entering into polemics with the positivists and appealing to the idea of the legal principle, R. Dworkin had to explain how "law can change, while remaining unchanged. And how is it possible to give two opposite answers to the same question, being right in each of the cases" [5, p. 21]. Thus, the question of the relationship, on the one hand, variability in law (including 
in the historical perspective), and its absolute, eternal principles, on the other hand, is one of the constant questions in the theory of law.

The above-mentioned assessment by A. Heinold of the "theory of principles" of R. Dworkin as a kind of "third way" in the theory of law is based on the opposition of the theory of natural law and positivism as "two poles" in the historical development of the foundations of ideas about law [12, p. 46]. Following this logic, A. Heinold sees the essence of the natural-legal theoretical model in the deduction of the principles of law from the general principles of morality, and the essence of the positivist model - in the empirical substantiation of the norms of law and norms of morality from the system of social relations. In the last version of the substantiation, the norms of law and norms of morality act relatively independently of each other.

In this interpretation of the history of legal doctrines, the option proposed by $R$. Dworkin really seems to be an alternative, since it offers a substantiation of the principles of morality and principles of law, although they are different in essence, however, and not opposed to each other, not contradicting each other, not distant from each other from a friend with an insurmountable wall.

We think that one can generally agree with such an interpretation, however, one must bear in mind all the diversity and complexity of the historical development of the theory of natural law. Especially in its later versions, in those versions that we find in German classical philosophy.

So, in the work of I.G. Fichte "The basis of natural law according to the principles of scientific teaching" we see the experience of parallel and independent deduction of morality and law from a single higher foundation [3, p. 74; 4, c. 53]. Nevertheless, we must agree that in the works of R. Dworkin we find a significant development of the general theoretical and methodological principles of modern Western science on the fundamental foundations of law.

\section{Bibliographic list}

1. Dworkin R. About rights seriously. M., 2004 / Per. from English; Ed. L. B. Makeeva. Moscow: "Russian political encyclopedia" (ROSSPEN), 2004. 392 p.

2. Ignatkin OB "Equality in Freedom": Principles of the Political Philosophy of Ronald Dworkin. Moscow: Publishing Center of the Russian State University for the Humanities, 2008. 201 p.

3. Maslennikov D.V., Revnova M.B. Dialectics of the subjective and objective in the substantiation of law by the classics of German philosophy // Legal thought. 2020. No. 3 (119). P. 74-91.

4. Fichte I.G. The basis of natural law according to the principles of science. Moscow: "Canon +", 2014. 391 p.

5. Churnosov I.M. Ronald Dvorkin's legal concept: diss. ... Cand. jurid. sciences. Moscow, 2014. 254 p.

6. Barbosa L.F. Influence of Ethics in the Concept of Law: Actual Stage of the "Hart-Dworkin Debate" / / XXVI World Congress of Philosophy of Law and Social Philosophy. Belo Horizonte: Forum, 2013. P. 448-449.

7. Braun J. Rechtsphilosophie im 20. Jahrhundert. Die Rückkert der Gerechtigkeit. München: Verlag C.H. Beck, 2001.

8. Dworkin R. Is Democracy Possible Here? Principles For a New Political Debate. Princeton: Oxford, 2006. 
9. Dworkin R. Justice for hedgehogs. London: Belknap Press, 2011.

10. Dworkin R. Law's Empire. London: Fontana, 1986.

11. Dworkin R. Sovereign Virtue: The Theory and Practice of Equality. Cambridge, MA: Harvard University Press, 2000.

12. Heinold A. Die Prinzipientheorie bei Ronald Dworkin und Robert Alexy. Berlin: Duncker \& Humbolt, 2011.

13. Senn M. Rechts- und Gesellschaftsphilosopie. Historische Fundamente der europäischen, nordamerikanischen, indischen sowie chinesisch Rechts - und Gesellschaftsphilosophie. Eine Einführung mit Quellenmaterial. Zürich: Dike Verlag, 2012.

Please cite this paper as: Prokofiev K.G., Ivanov D.V. Ronald Dvorkin's "Theory of Principles" - "The Third Way" in the Theory of Law? // Legal thought. 2021. No. 4 (124). P. 109-113.

DOI: $10.47905 /$ MATGIP.2021.124.4.009

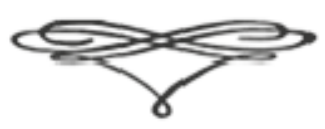




\section{Нарковезопасное ОБЩЕство как оПреАЕкяюЩнй фактор современного этапа соцнального развнтия Россин}

\section{H.d. Фролова*}

Аннотация. В статье акцентируется внимание на понимание сущности антинаркотической политики и несводимости её к политике уголовной или политике социальной. Отстаивается, что в условиях развития современного общества требуется особая проработанность антинаркотической политики, как нового направмения деятельности государства.

Наркоситуацию необходимо рассматривать в качестве объективной оценки соотношения сил сторон "ЗА" наркотики и "ПРОТИВ" наркотиков в конкретном административно-территориальном образовании, в связи с чем, следует исходить из принципа равной ответственности всех ветвей вцасти за наркоситуацию в городе, регионе, муниципалитете.

Достижение наркобезопасного общества - это показатель особой профессиональной деятельности политического и управленческого уровня.

К^ючевые слова: наркобезопасное общество, социальное развитие, антинаркотическая политика, давление наркосреды, ответственность вцасти, наркореальность.

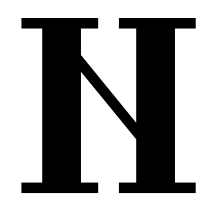

овая политико-правовая ситуация, отражающая особенности развития России в начале XXI века, четко обозначила задачи сохранения и укрепления человеческих ресурсов, социальнонравственного потенциала общества, повышения эффективности управцения государственным развитием.

Немаловажной задачей остается совершенствование тех сфер, которые активно формируют общественный менталитет, позволяют мокализовать угрозы безопасности мичности, общества, государства.

Реальность угрозы дальнейшего распространения наркомании, как формы девиантного поведения и связанного с ней незаконного оборота наркотиков, складывается из определенных факторов как внутреннего, так и внешнего характера. Среди основных внутренних факторов следует отметить социальное неблагополучие, безработицу, особенно среди молодежи, низкий уровень качества жизни широких слоев населения. Отталкиваясь от понимания качества жизни как категории, выражающей "качество удов-

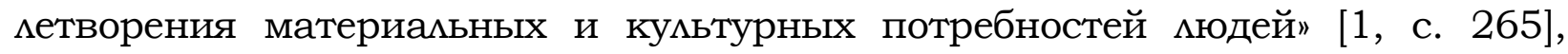
а практически степень удовцетворенности образом жизни, трудом, бытом, досугом, следует признать, что данная базовая аналитическая категория отражает оценку социального развития как человека, так и общества.

* Фролова Наталья Алексеевна, доктор юридических наук, профессор, Заслуженный работник высшей школы Российской Федерации, действительный чмен Академии проблем безопасности (г. Москва). E-mail: frolova.rags@yandex.ru 
Материальные и духовные условия среды, в которых находится человек, в гораздо большей степени вцияют на формирование вцечения к наркотикам, чем что-либо иное. Не удовлетворяющие человека условия жизни перманентно подвигают его к поиску путей ухода от действительности, один из которых - наркотики. Принятые в обществе нормы поведения, система ценностей, этика, моральные принципы, ориентация на те или иные имиджи, понятие справедмивости, престижа, - все это оказывает большое влияние на каждого конкретного человека.

С изменением идеологической парадигмы государства стали появляться и увеличиваться зоны праздности в обществе наряду с катастрофическим падением престижа добросовестного производительного труда. Культивирование игрового стиля жизни, азартного существования, инстинкта удовольствия на фоне удручающей обыденности стало "носителем микроба деиндустриализации" [2, с. 73], насаждения примитивных, упрощенных схем поведения, негативного конформизма.

Многопозиционность данного фактора отражается и в том, что результатом существенного ослабления института семьи явились рост численности безнадзорных и беспризорных детей, увемичение распространения в детской и подростковой среде наркотиков и различных психотропных препаратов, алкоголя, ведущие к правонарушениям среди несовершеннолетних. Подрыв потенциала семьи, как основы общества, здоровых семейных традиций усиливает негативную детерминацию наркозависимости, ослабляет действенный ресурс антинаркотического сознания, способствует распространению различных заболеваний, в том числе ВИЧ-инфекции, а также увеличению рецидивов асоциального поведения.

Наркомания, став в современных условиях серьезной гуманистической проблемой и имеющей комплексный характер, включает многие аспекты, в том числе международные и межконфессиональные отношения, сферу права, социальной психологии, систему общественных ценностей. С междисциплинарных позиций в своей сущности наркомания - это заболевание индивида, обусловленное зависимостью, возникающей вследствие многократного незаконного приобретения, хранения и потребления наркотических средств или психотропных веществ.

В данном аспекте медицинская основа дополняет юридическое содержание, в связи с чем, наркомания всецело взаимосвязана с незаконным оборотом наркотиков, который способствует наркотизации общества - негативному социальному явлению вовлечения в наркоманию определенной части социальных групп, оказывающему деструктивное влияние на правовую систему общества и основы государства.

Негативное воздействие, которое оказывает распространение наркомании на правовую систему общества, проявляется главным образом в нарушении ее функционирования как социально-юридического образования. Это связано с тем, что незаконное потребление наркотиков, явцяясь противоправной деятельностью, в своей основе разрушает нормы права, общественные интересы, правопорядок, социальные и правовые отношения. Данные проявления способствуют разрушению социальных связей, которое сопровождается негативным вциянием на уровень правосознания и право- 
вой кумьтуры граждан, в связи с чем, нарушается необходимая дмя правовой системы общества стабильность.

Негативное влияние наркотизации проявляется в формировании тенденции рассогласования права, правотворческой и правореализационной практики, в деструктивной направленности на социально-экономические, политико-правовые и нравственные основы государства. Опасность данного явления усиливается ввиду того, что доходы от наркобизнеса используются для финансовой поддержки внутригосударственной и международной организованной преступности.

Следует отметить, что проблемами незаконного распространения наркотиков и роста наркотизации населения в современном российском обществе в своем формате занимаются социологи, юристы, медики, психомоги, педагоги, журналисты и представители многих других профессий (химики, фрармакологи, международники, экономисты и т. д.). Во многих размышлениях, выступлениях, исследованиях по вопросам государственной политики контроля наркотиков, а также недостаточной степени эффективности работы в стране по защите молодежи от наркомании сущность антинаркотической политики и ее отличия от политики уголовной и социальной рассматриваются зачастую не на уровне понимания политического формата наркореальности.

Так, если уголовная политика - это деятельность государства по защите граждан и общества от преступных посягательств и преступлений в целом, то ее содержанием является разработка целей и задач, выработка средств и методов борьбы с преступностью. В контексте авторского анализа речь идет о защите от преступных посягательств и преступлений, связанных с наркотиками, т. е. о борьбе с наркопреступностью.

Соииальная политика - это составная часть общей стратегии государства, относящаяся к социальной сфере: целенаправленная деятельность по выработке и реализации решений, непосредственно касающихся человека, его положения в обществе, по предоставлению ему социальных гарантий с учетом особенностей разцичных групп насемения страны. Опирающаяся на широкую общественную поддержку социальная политика предназначена аккумулировать, фокусировать, отражать обстановку в стране и ситуацию в обществе, потребности и цели социального развития. Это, в том числе, решения, которые защищают подростка от курения табака и от пьянства, удерживают молодого человека от наркозависимости или помогают наркоману в устойчивой ремиссии удерживаться от очередного срыва.

Смысл антинаркотической политики, отличающийся от смысла угомовной и социальной политики, заключается в том, что антинаркотическая политика - это управление наркоситуаиией посредством формирования негативно-дифоререниированного отношения населения $\kappa$ участникам незаконного оборота наркотиков, установления правового запрета рекламы, пропаганды наркотических средств (психотропных вешеств) и их немедииинского потребления, реализаиии контроля соблюдения этого запрета физическими и юридическими лииами и применения $\kappa$ нарушителям административных санкиий, жесткость и интенсив- 
ность которых должна быть достаточной для постепенного уменьиения экспозииионного давления наркосредъ.

Введенное в научный оборот шведским ученым Н. Бейерутом понятие экспозииионного давления наркосреды, зависящего от совокупности определенных факторов, и в современных исследованиях антинаркотической политики подтверждается ранжированностью следующих факторов наркореальности [3, с. 98]:

1) друзья, потребляющие наркотики;

2) доступность наркотиков (цены);

3) отношение СМИ и рядовых граждан;

4) действующее законодательство;

5) политика государства в этой сфере;

6) социальные условия;

7) знания о последствиях потребления.

Реализация в государстве в необходимом объеме антинаркотической политики должна обеспечиваться и дополняться научно-теоретической проработанностью этого нового направления государственной деятельности, поскольку ни уголовная, ни социальная политика не могут обеспечить необходимый для устойчивого развития общества уровень наркобезопасности. Само понятие сущности наркоситуации, как правило, понимается в контексте Аибо уголовной, Аибо социальной политики.

С точки зрения антинаркотической политики наркоситуаиия - это некая результирующая, производная от действий всех социальных сил. Наркоситуация - это не просто ситуация с наркотиками на территории в какой-то момент времени, это не только совокупность статистических результатов работы ведомств, участвующих в противодействии зцоупотреблению наркотиками и их незаконному обороту. Это акцент не на том, что́ удалось сделать стороне "против" наркотиков (проведено столько-то акций по профилактике наркомании, выявлено столько-то наркопреступлений, изъято столько-то наркотиков, пролечено столько-то миц с диагнозом наркомании и т. д.), а на то́м, какими ресурсами располагает сторона «за» наркотики и насколько результаты работы, прежде всего, правоприменительных органов ее ослабили/не ослабили.

Наркоситуация для ответственной вмасти - это объективная оценка соотношения сиц сторон "за" и "против" наркотиков в конкретном административно-территориальном образовании. Возникающие новые наркоугрозы - это новые события в жизни общества или индивида (новый закон, новое решение, новый фильм, новая мода, новый сайт, новый друг и т. д.), которые оказывают воздействие на факторы, определяющие экспозиционное давление наркосреды. Наркоугроза - это то, что ослабляет сторону "против наркотиков" или (и) усиливает сторону "за наркотики". В конечном счете каждая реализованная новая наркоугроза способствует переходу социума из наркобезопасного в наркопораженное состояние.

Если обратиться к некоторым конкретным примерам влияния факторов на наркосреду и состояние наркоситуации, то можно отметить разные подходы, в частности:

- наркоугроза, связанная с фактором политики государства. Ее проявлением стало назначение в 1994 году Председателем Правительства РФ 
Виктором Черномырдиным на должность председателя созданной в Российской Федерации Правительственной комиссии по противодействию зцоупотреблению наркотическими средствами и психотропными веществами никогда не работающего в сфере борьбы с наркотиками и некомпетентного в данной сфере своего заместителя Сергея Шахрая. По мере того, как подобная кадровая политика с федерального уровня копировалась на уровень субъекта Федерации, надежды на то, что межведомственные комиссии (MBK) обеспечат реальную координацию антинаркотических структур, исчезала. В результате наступим длительный период декорации и декмарирования антинаркотической политики в России;

- наркоугроза, связанная с доступностью наркотиков. Так, в 1998 году один "чек" уличного героина в Санкт-Петербурге стоим всего 60 рублей, и учащимся ПТУ достаточно было два раза не пообедать, чтобы иметь сумму денег, достаточную дия его покупки.

Конкретность действенного подхода позволяет стороне "против наркотиков" фиксировать появление новых наркоугроз на региональном уровне и эффективно действовать против них, чтобы они не превращали реальность в наркопораженный социум. Продажа в "Доме книги" в СанктПетербурге в 2002 году книги "Психогенные грибы", квалифицированной экспертами как пособие по их выращиванию и потреблению, была прекращена, как только приобретенная книга попала к мировому судье, и он назначим административный штраф руководству магазина. Демонстрация в 2004 году по ТВ-6 пропагандирующего курение марихуаны видеоклипа

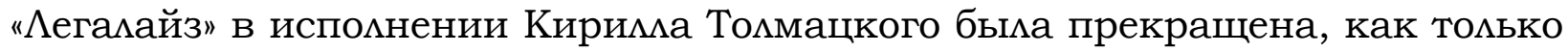
сдеманная запись видеокмипа поступила в прокуратуру Санкт-Петербурга, и она вынесла официальное предостережение продюсеру этого телевизионного канала [3, с. 98-100].

Сегодня новой наркоугрозой явцяется процветание значительного числа наркопораженных ночных клубов в России, и от того, удастся с ней справиться стороне "против наркотиков" или нет, во многом зависит вся антинаркотическая политика в нашей стране. Возможно, что руководители региональных правительств (губернаторы), а соответственно, и руководитеми их структурных подраздемений (здравоохранения, образования, СМИ, по делам молодежи и т. д.) находятся в плену можных представцений о том,

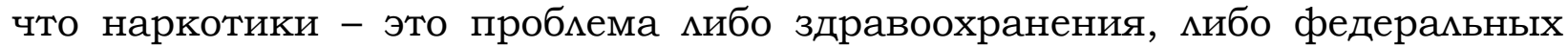
силовых структур. Эти представцения устарели.

Чтобы позитивные изменения наступими, необходимо исходить из следующих важных теоретических оснований.

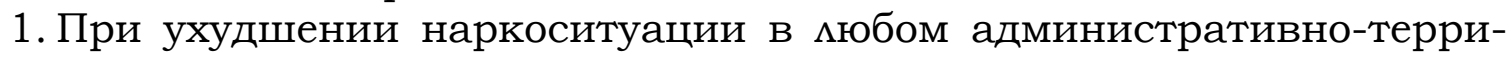
ториальном образовании нужно не искать крайнее ведомство, а исходить из приниипа равной ответственности всех ветвей власти за наркоситуаиию в регионе, городе, мунииипалитете, усиливая сторону "против наркотиков" или ослабляя сторону "за наркотики", одновременно анализируя возможности появцения новой наркоугрозы.

2. Государственная антинаркотическая политика, не поддерживаемая сетью обиественных организаиий из активных граждан, не может быть эффективной в принципе из-за сетевой природы наркорынка. 
3. Теоретическая модемь эффективной антинаркотической политики должна состоять из четырех блоков: знания, стратегии, координаиии и лидерства.

ДАя успешной борьбы с наркоугрозой и дмя достижения наркобезопасного общества государству в современном информационном пространстве необходимо развивать блок "знания" путем введения в научнопрактический оборот категории "конфмикт" и понятия "наркоконфмикт", что подтверждает диалектический подход к анализу тематического понятийного аппарата, отражающего определенную фрагментарность в контексте темпоральных изменений наркореальности.

Таблица 1

\begin{tabular}{|c|c|c|c|}
\hline Медики & Юристы & Психологи & Конфмиктологи \\
\hline до 1980 & 1990 & 2000 & 2010 \\
\hline болезнь & преступление & поведение & конфмикт \\
\hline \multirow{3}{*}{ наркомания } & наркопреступность & наркозависи- & наркокононфиикт \\
& наркотиков (НОН) & мость & \\
\hline
\end{tabular}

Полагаем необходимым отметить важный аспект, отражающий то, что исторически представители различных профессий из тех, которые выступали в качестве антинаркотических экспертов у российской государственной власти, включая времена СССР, сменяли друг друга: сначала юристы сменили медиков, потому что наркоситуация продолжала ухудшаться, потом психологи сменили юристов, потому что наркоситуация еще более ухудшилась. К 2010 году практика показала, что в рамках узкоотраслевых специалистов невозможно справиться с решением задачи по изменению наркореальности и для успешного управления наркоситуацией недостаточно ее анализировать только в таких понятиях, как "наркомания", "наркопреступность" и "наркозависимость", явцяющихся производными от категорий: "болезнь", "преступление", "поведение». Наркореальность в самой своей природе содержит противоборство и несовместимость целей множества реально действующих субъектов: политических, экономических, социальных, информационных и иных профилей.

В связи с этим столь востребованный для достижения общества, свободного от наркотиков, междисциплинарный подход, который соотносится с научным конфциктологическим знанием, механизмом координации, цемевой стратегией, профессиональной ответственностью специалистов, дает реальную возможность:

а) проводить в государстве эффективную антинаркотическую политику, основанную на конфликтологическом анализе наркоситуации, экономически оцениваемой результативности профилактики наркомании перед ее мечением и многократном приоритете административного предупреждения наркопреступности перед ее уголовно-правовым пресечением;

б) объективно оценивать антинаркотическую деятельность административно-территориального образования по совокупности показателей, 
характеризующих вкцад каждого органа государственной вмасти, местного самоуправления в результаты борьбы с наркоугрозами;

в) активно вкцючать в антинаркотическую деятельность институты гражданского общества в виде сети антинаркотических общественных организаций современной России.

Борьба за наркобезопасное общество должна стать особым видом профессиональной деятельности, особенно на политическом и управленческом уровнях. Только путь безопасного социального развития вырабатывает способность государственных и общественных институтов к опережению возникающих в современной действительности рисков и угроз, обеспечивая системную организацию национальной безопасности.

\title{
Бибциографический список
}

1. Энциклопедический социологический словарь / Под общ. ред. академика РАН Осипова Г.В. - М.: ИСПИ РАН, 1995. - С. 265.

2. ГАобализм, новая элита, демографическая война против России / Под ред. д.э.н., проф. Прохожева А.А. - М.: Информиздатцентр, 2002. - С. 73.

3. Зазулин Г.В. Антинаркотическая политика в России: Пробцемы становления (2000-2013 годы). - СПб.: Издательство "Юридический центр-Пресс», 2013. $336 \mathrm{c.}$

Дия цитирования: Фролова Н.А. Наркобезопасное общество как определяющий фактор современного этапа социального развития России: статья // Юридическая мысль. 2021. - № 4 (124). - C. 114-120.

DOI: $10.47905 /$ MATGIP.2021.124.4.010

\section{Drug-safe society as a determining factor of the modern stage of social development of Russia}

\author{
Natalia A. Frolova*
}

Annotation. The article focuses on understanding the essence of anti-drug policy and its irreducibility to criminal or social policy. It is argued that in the conditions of the development of modern society, a special elaboration of anti-drug policy is required as a new direction of state activity.

The drug situation should be considered as an objective assessment of the balance of forces of the parties "FOR" drugs and "AGAINST" drugs in a particular administrative-territorial formation, in connection with which it is necessary to proceed from the principle of equal responsibility of all branches of government for the drug situation in the city, region, and municipality.

The achievement of a drug-safe society is an indicator of a special professional activity at the political and managerial level.

Keywords: drug-safe society, social development, anti-drug policy, drug environment pressure, government responsibility, drug reality.

* Frolova Natalia Alekseevna, Doctor of Law, Professor, Honored Worker of the Higher School of the Russian Federation, full member of the Academy of Security Problems (Moscow). E-mail: frolova.rags@yandex.ru 
The new political and legal situation, reflecting the peculiarities of the development of Russia at the beginning of the 21 st century, clearly outlined the tasks of preserving and strengthening human resources, the social and moral potential of society, and increasing the efficiency of state development management.

An important task is to improve those spheres that actively form the social mentality, allow to localizing threats to the security of an individual, society, and the state.

The reality of the threat of further spread of drug addiction, as a form of deviant behavior and related drug trafficking, is made up of certain factors, both internal and external. Among the main internal factors, it should be noted social disadvantage, unemployment, especially among young people, a low level of quality of life of the general population. Starting from the understanding of the quality of life as a category that expresses the "quality of satisfaction of the material and cultural needs of people" [1, p. 265], but in practice the degree of satisfaction with the way of life, work, everyday life, leisure, it should be recognized that this basic analytical category reflects the assessment of the social development of both a person and society.

The material and spiritual conditions of the environment in which a person is located have a much greater influence on the formation of cravings for drugs than anything else. The conditions of life that do not satisfy a person permanently encourage him to search for ways to escape reality, one of which is drugs. The norms of behavior accepted in society, the system of values, ethics, moral principles, orientation towards certain images, the concept of justice, prestige - all this has a great influence on each individual person.

With the change in the ideological paradigm of the state, zones of idleness began to appear and increase in society, along with a catastrophic decline in the prestige of conscientious productive labor. The cultivation of a gambling lifestyle, gambling existence, the instinct of pleasure against the background of depressing everyday life has become a "carrier of the microbe of deindustrialization" [2, p. 73], the planting of primitive, simplified patterns of behavior, negative conformism.

The multi-position nature of this factor is reflected in the fact that the result of a significant weakening of the institution of the family was an increase in the number of neglected and street children, an increase in the spread of drugs and various psychotropic drugs, alcohol in children and adolescents, leading to delinquency among minors. Undermining the potential of the family as the basis of society, healthy family traditions enhances the negative determination of drug addiction, weakens the effective resource of anti-drug consciousness, contributes to the spread of various diseases, including HIV infection, as well as an increase in the relapse of antisocial behavior.

Drug addiction, having become in modern conditions a serious humanistic problem and having a complex character, includes many aspects, including international and interfaith relations, the sphere of law, social psychology, and the system of social values. From an interdisciplinary standpoint, in essence, drug addiction is an individual's illness caused by addiction arising from re- 
peated illegal acquisition, storage and consumption of narcotic drugs or psychotropic substances.

In this aspect, the medical basis complements the legal content, in connection with which drug addiction is entirely interconnected with illegal drug trafficking, which contributes to drug addiction in society - a negative social phenomenon of involving a certain part of social groups in drug addiction, which has a destructive effect on the legal system of society and the foundations of the state.

The negative impact that the spread of drug addiction has on the legal system of society is manifested mainly in the disruption of its functioning as a social and legal entity. This is due to the fact that illegal drug use, being an illegal activity, basically destroys the rule of law, public interests, law and order, social and legal relations. These manifestations contribute to the destruction of social ties, which is accompanied by a negative impact on the level of legal consciousness and legal culture of citizens, in connection with which the stability necessary for the legal system of society is violated.

The negative impact of drug addiction is manifested in the formation of a tendency to inconsistency of law, law-making and law-enforcement practice, in a destructive focus on the socio-economic, political, legal and moral foundations of the state. The danger of this phenomenon is increasing due to the fact that the proceeds from the drug business are used to financially support domestic and international organized crime.

It should be noted that sociologists, lawyers, physicians, psychologists, teachers, journalists and representatives of many other professions (chemists, pharmacologists, international affairs experts, economists, etc.) ... In many reflections, speeches, studies on the issues of state drug control policy, as well as the insufficient degree of effectiveness of work in the country to protect young people from drug addiction, the essence of anti-drug policy and its differences from criminal and social policies are often not considered at the level of understanding political format of drug reality.

So, if criminal policy is the activity of the state to protect citizens and society from criminal encroachments and crimes in general, then its content is the development of goals and objectives, the development of means and methods of combating crime. In the context of the author's analysis, we are talking about protection from criminal encroachments and drug-related crimes, that is, about the fight against drug crime.

Social policy is an integral part of the general strategy of the state related to the social sphere: purposeful activity to develop and implement decisions that directly relate to a person, his position in society, to provide him with social guarantees, taking into account the characteristics of various groups of the country's population ... Based on broad public support, social policy is designed to accumulate, focus, reflect the situation in the country and the situation in society, the needs and goals of social development. Among other things, these are solutions that protect a teenager from smoking tobacco and drunkenness, keep a young person from drug addiction or help a drug addict to keep from another breakdown in stable remission. 
The meaning of anti-drug policy, which differs from the meaning of criminal and social policy, is that anti-drug policy is the management of the drug situation through the formation of a negatively differentiated attitude of the population towards participants in drug trafficking, the establishment of a legal prohibition of advertising, the promotion of narcotic drugs (psychotropic substances) and their non-medical consumption, the implementation of control over the observance of this prohibition by individuals and legal entities and the application of administrative sanctions to violators, the severity and intensity of which should be sufficient to gradually reduce the exposure pressure of the drug environment.

The concept of exposure pressure of the drug environment, which depends on a combination of certain factors, introduced into scientific circulation by the Swedish scientist N. Beyerut, and in modern studies of anti-drug policy is confirmed by the ranking of the following factors of drug reality [3, p. 98]:

1) friends who use drugs;

2) availability of drugs (prices);

3) the attitude of the media and ordinary citizens;

4) current legislation;

5) state policy in this area;

6) social conditions;

7) knowledge about the consequences of consumption.

The implementation of the anti-drug policy in the state in the required volume should be ensured and supplemented by the scientific and theoretical elaboration of this new direction of state activity, since neither criminal nor social policy can provide the level of drug safety necessary for the sustainable development of society. The very concept of the essence of the drug situation, as a rule, is understood in the context of either criminal or social policy.

From the point of view of anti-drug policy, the drug situation is a kind of resultant, derivative from the actions of all social forces. The drug situation is not just a situation with drugs on the territory at some point in time, it is not only a set of statistical results of the work of departments involved in combating drug abuse and drug trafficking. This is not an emphasis on what the side "against" drugs has managed to do (so many actions have been carried out to prevent drug addiction, so many drug crimes have been identified, so many drugs have been seized, so many people diagnosed with drug addiction have been treated, etc.) .), but on what resources the party "for" drugs has and to what extent the results of the work, first of all, of the law enforcement agencies have weakened / did not weaken it.

The drug situation for a responsible government is an objective assessment of the balance of forces between the parties "for" and "against" drugs in a particular administrative-territorial entity. Emerging new drug threats are new events in the life of society or an individual (new law, new decision, new film, new fashion, new website, new friend, etc.) that influence the factors that determine the exposure pressure of the drug environment. The drug threat is what weakens the "anti-drugs" side and / and strengthens the "pro-drugs" side. Ultimately, each new drug threat that is implemented contributes to the transition of society from drug-safe to drug-addicted state. 
If we turn to some specific examples of the influence of factors on the drug environment and the state of the drug situation, we can note different approaches, in particular:

- drug threat associated with the factor of state policy. Its manifestation was the appointment in 1994 by the Chairman of the Government of the Russian Federation Viktor Chernomyrdin to the post of chairman of the Government Commission on the prevention of drug and psychotropic substance abuse, created in the Russian Federation, who never worked in the fight against drugs and was incompetent in this area his deputy Sergey Shakhrai. As such a personnel policy was copied from the federal level to the level of the constituent entity of the Federation, the hopes that the interdepartmental commissions (IAC) would provide real coordination of anti-drug structures disappeared. As a result, a long period of decoration and declaration of anti-drug policy in Russia began;

- the drug threat associated with the availability of drugs. For example, in 1998, one "check" of street heroin in St. Petersburg cost only 60 rubles, and vocational school students had only to dine twice in order to have enough money to buy it.

The specificity of an effective approach allows the "against drugs" side to record the emergence of new drug threats at the regional level and to act effectively against them so that they do not transform reality into a drug-affected society. The sale in the House of Books in St. Petersburg in 2002 of the book "Psychogenic mushrooms", qualified by experts as a manual for their cultivation and consumption, was terminated as soon as the purchased book got to the magistrate, and he imposed an administrative fine on the management of the store ...

The demonstration in 2004 on TV-6 of the video clip "Legalize", which promoted smoking marijuana, performed by Kirill Tolmatsky, was stopped as soon as the video clip was received by the prosecutor's office of St. Petersburg, and she issued an official warning to the producer of this television channel [3, p. 98-100].

Today, a new drug threat is the prosperity of a significant number of drug-addicted nightclubs in Russia, and the whole anti-drug policy in our country largely depends on whether the "anti-drug" side can cope with it or not. It is possible that the heads of regional governments (governors), and, accordingly, and the heads of their structural units (health care, education, media, youth affairs, etc.) are captivated by the false idea that drugs are the problem is either health care or federal power structures. These views are outdated.

For positive changes to occur, it is necessary to proceed from the following important theoretical foundations.

4. When the drug situation worsens in any administrative-territorial entity, one should not look for an extreme department, but proceed from the principle of equal responsibility of all branches of government for the drug situation in the region, city, municipality, strengthening the "against drugs" side or weakening the "for drugs" side, at the same time analyzing the possibilities of the emergence of a new drug threat. 
5. State anti-drug policy, not supported by a network of public organizations of active citizens, cannot be effective in principle due to the network nature of the drug market.

6. A theoretical model of an effective drug policy should consist of four blocks: knowledge, strategy, coordination and leadership.

To successfully combat the drug threat and to achieve a drug-safe society, the state in the modern information space needs to develop a block of "knowledge" by introducing the category of "conflict" and the concept of "drugconflict" into scientific and practical circulation, which confirms the dialectical approach to the analysis of the topic technical conceptual apparatus, reflecting a certain fragmentation in the context of temporal changes in drug reality.

Table 1

\begin{tabular}{|c|c|c|c|}
\hline Physicians & Lawyers & Psychologists & Conflictologists \\
\hline for 1980 & 1990 & 2000 & 2010 \\
\hline disease & crime & behavior & conflict \\
\hline drug & $\begin{array}{l}\text { addiction drug crime } \\
\text { drug trafficking (IDT) }\end{array}$ & drug addiction & drug conflict \\
\hline
\end{tabular}

We believe it necessary to note an important aspect, reflecting the fact that historically, representatives of various professions from those who acted as anti-drug experts in the Russian government, including the times of the USSR, replaced each other: first, lawyers changed doctors, because the drug situation continued to deteriorate, then psychologists changed lawyers, because the drug situation has deteriorated even more. By 2010, practice has shown that within the framework of narrow-industry specialists it is impossible to cope with the solution of the problem of changing the drug reality, and for the successful management of the drug situation it is not enough to analyze it only in terms of "drug addiction", "drug crime" and "drug addiction", which are derived from the categories: "Disease", "crime", "behavior". Drugreality in its very nature contains confrontation and incompatibility of goals of many really acting subjects: political, economic, social, informational and other profiles.

In this regard, the interdisciplinary approach, which is so demanded to achieve a drug-free society, which correlates with scientific conflictological knowledge, a coordination mechanism, target strategy, professional responsibility of specialists, provides a real opportunity:

a) pursue an effective anti-drug policy in the state based on a conflictological analysis of the drug situation, the economically assessed effectiveness of drug abuse prevention over its treatment, and the multiple priority of administrative prevention of drug crime over its criminal law suppression;

b) objectively assess the anti-drug activity of the administrative-territorial entity by a set of indicators characterizing the contribution of each state authority, local self-government to the results of the fight against drug threats;

c) actively include civil society institutions in anti-drug activities in the form of a network of anti-drug public organizations in modern Russia. 
The fight for a drug-safe society must become a special kind of professional activity, especially at the political and managerial levels. Only the path of safe social development develops the ability of state and public institutions to outstrip the risks and threats that arise in modern reality, ensuring the systemic organization of national security.

\section{Bibliographic list}

1. Encyclopedic Sociological Dictionary / Under total. ed. Academician of RAS G.V. Osipova M .: ISPI RAN, 1995. P. 265.

2. Globalism, New Elite, Demographic War against Russia / Ed. Doctor of Economics, prof. A.A. Prokhozheva. Moscow: Informizdatcentr, 2002. P. 73.

3. Zazulin G.V. Anti-Drug Policy in Russia: Problems of Formation (2000-2013). St. Petersburg: Publishing house "Legal Center-Press", 2013. 336 p.

For citation: Frolova N.A. Drug-safe society as a determining factor in the modern stage of social development in Russia: article // Legal thought. 2021. No. 4 (124). P. 120-126.

DOI: $10.47905 /$ MATGIP.2021.124.4.010

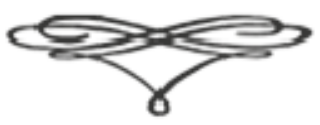




\title{
УдК 340 \\ ББK 67.0 \\ DOI: $10.47905 / M A T G I P .2021 .124 .4 .015$
}

\author{
Маукограды Росснн: \\ Современное СОстоянне \\ н перспектнвы развнтня
}

\section{G.đ. Шеркунов ${ }^{*}$}

\begin{abstract}
Аннотация. В настоящей статье представлена краткая справка по формированию и развитию городов науки в нашей стране; актуализирована информация по численности населения, основным направлениям исследований, проводимым научными организациями и научно-производственными объединениями муниципальных образований, наделённых статусом наукоградов; определены перспективы развития городов, связанные с формированием и реализацией проектов, созданных с использованием сервисов мультимедийных платформ, конструкторов стратегий.
\end{abstract}

К^ючевые слова: наукоград, академгородок, город будущего, Союз развития наукоградов России, Агентство стратегических инициатив по продвижению новых проектов.

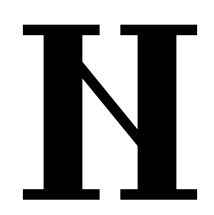

аукоград (град науки, в советский период) или технополис - это муниципальное образование, надеменное статусом городского округа в соответствии с Федеральным законом от 6 октября 2003 года № 131-Ф3 “Об общих принципах организации местного самоуправления в Российской Федерации" [2], градообразующую базу которого формируют организации научной и/или научнопроизводственной сферы. Наукограды, как правило, имеют развитую инновационную инфраструктуру, в том числе, индустриальные парки, инжиниринговые центры, бизнес-инкубаторы и акселераторы.

Первые грады науки появились в нашей стране в 1930-е - 1940-е годы: г. Жуковский (Московская область), п. Саров, ныне - г. Саров на границе Горьковской (Нижегородской) области и Мордовской АССР (Республика Мордовия). В 1933 году было принято решение о создании на территории современного г. Жуковский Центрального аэрогидродинамического института. В настоящее время, доля работников, занятых на предприятиях

* Шеркунов Сергей Александрович, заместитель заведующего кафедрой государственного и муниципального управления и права Федерального государственного бюджетного образовательного учреждения высшего образования "Московский педагогический государственный университет»; доцент Института государственной службы и управления Федерального государственного бюджетного образовательного учреждения высшего образования "Российская академия народного хозяйства и государственной службы при Президенте Российской Федерации»; кандидат экономических наук. E-mail: sa.sherkunov@ mpgu.su 
научно-производственного комплекса г. Жуковский составляет 40,28 \% от общей численности занятых в отраслях экономики [12].

В 1946 году в п. Саров начато строительство научного ядерного центра. Сегодня в научных организациях и научно-производственных объединениях г. Саров трудятся три академика РАН, 109 докторов и 504 кандидата наук [11].

В 1950-1960-е гг. был принят курс на фрормирование академгородков спутников крупных индустриальных центров Сибири - гг. Новосибирск, Красноярск, Иркутск, Томск.

С развитием атомной промышленности в СССР, города науки появимись в Пензенской области (г. Заречный), Челябинской области (гг. Озёрск, Снежинск (Челябинск-70) и Трёхгорный), Свердмовской области (гг. Новоуральск и Аесной), Томской области (г. Северск), Красноярском крае (гг. Жемезногорск и Земеногорск) [4].

Крупные центры многопрофильных научных исследований были созданы в Московской и Калужской областях. В 1954 году, в Калужской обмасти, был запущен первый реактор АЭС, ставшей градообразующим предприятием для г. Обнинска. 25 февраля 1971 года было подписано Распоряжение Совета Министров СССР № 331-рс о создании под г. Вцадимиром Опытного конструкторского бюро "Радуга" дия выполнения работ по государственному оборонному заказу [13]. Предприятие стало градообразующем дия г. Радужного, который в настоящее время является крупным центром мазерных технологий и имеет статус закрытого административнотерриториального образования (ЗАТО).

По выражению крупнейшего специалиста в области географии городов Г.М. Ааппо, города с высоким научным и инновационным потенциамом - спутники центров промышленно-городских агцомераций по многим показателям и свойствам являются "городами будущего" [5, с. 67].

В настоящее время, более шестидесяти муниципальных образований, расположенных в тех или иных субъектах Российской Федерации, претендуют на присвоение статуса наукограда. Данный статус позволяет территориям получить новый импульс к развитию, формированию точек экономического роста, проведению работы по корректировке стратегических пианов.

Инфографика муниципальных образований, имеющих высокий научно-технологический потенциал, представлена на платформе Ассоциации инновационных регионов России и Агентства стратегических инициатив по продвижению новых проектов.

Однако, официально статус наукограда носят только 14 муниципальных образований, находящихся в семи субъектах Российской Федерации. Первым градом науки, которому по Указу исполняющего обязанности Президента Российской Федерации В.В. Путина, 6 мая 2000 года быц присвоен статус наукограда, стал г. Обнинск - центр мирного атома [3]. Сводные данные по муниципальным образованиям, наделенным статусом наукограда, представцены ниже. 


\section{Сводные данные по муниципамьным образованиям, надеменным статусом наукограда [6]}

\begin{tabular}{|c|c|c|c|c|c|}
\hline $\begin{array}{c}\text { № } \\
\Pi / \Pi\end{array}$ & $\begin{array}{l}\text { Наимено- } \\
\text { вание } \\
\text { наукограда }\end{array}$ & $\begin{array}{l}\text { Субъект } \\
\text { РФ }\end{array}$ & $\begin{array}{c}\text { Дата } \\
\text { прис- } \\
\text { воения } \\
\text { статуса } \\
\text { (год) }\end{array}$ & $\begin{array}{c}\text { Численность } \\
\text { населения } \\
\text { на } 1.01 .2020 \\
\text { г., тыс. чем. }\end{array}$ & $\begin{array}{c}\text { Специализация, } \\
\text { основные направления } \\
\text { исследований }\end{array}$ \\
\hline 1 & 2 & 3 & 4 & 5 & 6 \\
\hline 1. & Обнинск & $\begin{array}{l}\text { Калуж- } \\
\text { ская } \\
\text { область }\end{array}$ & 2000 & 117,4 & $\begin{array}{l}\text { Многопрофимьные исследо- } \\
\text { вания: ядерная физика, } \\
\text { метеорология и сейсмоло- } \\
\text { гия, химия и фрармацевтика }\end{array}$ \\
\hline 2. & Дубна & $\begin{array}{l}\text { Москов- } \\
\text { ская } \\
\text { область }\end{array}$ & 2001 & 75,0 & $\begin{array}{l}\text { Ядерная физика; нанотех- } \\
\text { нологии }\end{array}$ \\
\hline 3. & Королёв & $\begin{array}{l}\text { Москов- } \\
\text { ская } \\
\text { область }\end{array}$ & 2001 & 225,9 & $\begin{array}{l}\text { Разработка и производство } \\
\text { ракетно-космической техни- } \\
\text { ки; исследования в области } \\
\text { космической деятельности }\end{array}$ \\
\hline 4. & $\begin{array}{l}\text { Мичу- } \\
\text { ринск }\end{array}$ & $\begin{array}{l}\text { Тамбов- } \\
\text { ская } \\
\text { обцасть }\end{array}$ & 2003 & 90,7 & $\begin{array}{l}\text { Семекция, генетика, биохи- } \\
\text { мия и биотехнологии; иссле- } \\
\text { дования агроэкосистем }\end{array}$ \\
\hline 5. & Кольцово & $\begin{array}{l}\text { Новоси- } \\
\text { бирская } \\
\text { обцасть }\end{array}$ & 2003 & 17,5 & $\begin{array}{l}\text { Вирусология, молекулярная } \\
\text { биология и биотехнологии }\end{array}$ \\
\hline 6. & Фрязино & $\begin{array}{l}\text { Москов- } \\
\text { ская } \\
\text { область }\end{array}$ & 2003 & 59,5 & 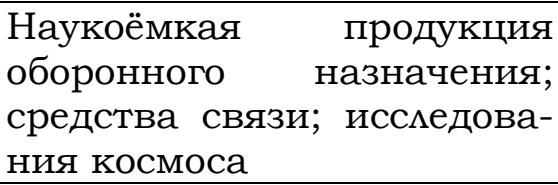 \\
\hline 7. & Реутов & $\begin{array}{l}\text { Москов- } \\
\text { ская } \\
\text { область }\end{array}$ & 2003 & 108,1 & $\begin{array}{l}\text { Разработка и производство } \\
\text { ракетно-космической тех- } \\
\text { ники }\end{array}$ \\
\hline 8. & Бийск & $\begin{array}{c}\text { А^тайский } \\
\text { край }\end{array}$ & 2005 & 209,2 & $\begin{array}{lr}\text { Наукоёмкая } & \text { продукция } \\
\text { оборонного } & \text { назначения; } \\
\text { индустрия } & \text { наносистем; } \\
\text { энергосбережение и ядер- } \\
\text { ная энергетика }\end{array}$ \\
\hline 9. & Петергоф & $\begin{array}{c}\text { Санкт- } \\
\text { Петербург }\end{array}$ & 2005 & 84,9 & $\begin{array}{l}\text { Многопрофильные исследо- } \\
\text { вания; малое инновацион- } \\
\text { ное предпринимательство }\end{array}$ \\
\hline 10. & Пущино & $\begin{array}{l}\text { Москов- } \\
\text { ская } \\
\text { область } \\
\end{array}$ & 2005 & 20,7 & Биомогия; космос \\
\hline 11. & $\begin{array}{l}\text { Жуков- } \\
\text { ский }\end{array}$ & $\begin{array}{l}\text { Москов- } \\
\text { ская } \\
\text { область }\end{array}$ & 2007 & 107,6 & $\begin{array}{l}\text { Наукоёмкая продукция обо- } \\
\text { ронного назначения; ин- } \\
\text { формационно-темекомму- } \\
\text { никационные системы; } \\
\text { транспортные, авиацион- } \\
\text { ные и космические систе- } \\
\text { мы; энергетика и энерго- } \\
\text { сбережение }\end{array}$ \\
\hline
\end{tabular}




\begin{tabular}{|c|c|c|c|c|c|}
\hline \multicolumn{6}{|r|}{ Окончание таблицы } \\
\hline 1 & 2 & 3 & 4 & 5 & 6 \\
\hline 12. & Троицк & Москва & 2007 & 61,0 & $\begin{array}{l}\text { Земной магнетизм, физика } \\
\text { высоких давєений }\end{array}$ \\
\hline 13. & Протвино & $\begin{array}{l}\text { Москов- } \\
\text { ская } \\
\text { область }\end{array}$ & 2008 & 35,4 & $\begin{array}{l}\text { Наукоёмкая продукция } \\
\text { оборонного назначения; } \\
\text { энергосбережение и ядер- } \\
\text { ная энергетика; информа- } \\
\text { ционно-телекоммуникаци- } \\
\text { он-ные системы; системы } \\
\text { безопасности }\end{array}$ \\
\hline 14. & $\begin{array}{l}\text { Черного- } \\
\text { мовка }\end{array}$ & $\begin{array}{l}\text { Москов- } \\
\text { ская } \\
\text { область }\end{array}$ & 2008 & 21,3 & $\begin{array}{l}\text { Наукоёмная } \\
\text { оборонного нуказния } \\
\text { физика; химия; минерало- } \\
\text { гия; биология }\end{array}$ \\
\hline
\end{tabular}

Особое положение - статус-кво и порядок осуществления государственной поддержки муниципальных образований, наделенных статусом наукоградов Российской Федерации, закреплен в Федеральном законе от 7 апреля 1999 года № 70-ФЗ «О статусе наукограда Российской Федерации" [1]. Вопросы развития наукоградов находятся в фокусе внимания

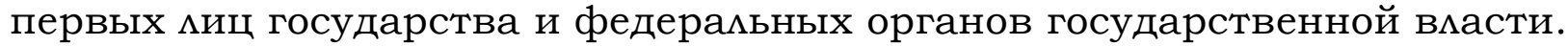

"Наукограды и научные центры нашей страны обладают большим потенциалом, подтверждением чему служат успешные разработки отечественных ученых", сказал Заместитель Председателя Совета Безопасности России Д.А. Медведев в ходе совещания 13 октября 2020 года на платформе Всероссийской политической партии "Единая Россия". "Мы домжны подумать над комплексной системой развития таких центров, включая вопросы поддержки молодых ученых, и привлечения бизнеса", отметил в своем докмаде Д.А. Медведев [9].

Проблемы социально-экономического развития наукоградов активно обсуждаются в ходе парламентских слушаний, круглых столов в Совете Федерации и Государственной Думе Федерального Собрания Российской Федерации. Так, в декабре 2020 года в Совете Федерации ФС РФ в режиме видеоконференции был проведен круглый стол, на котором были представлены мучшие региональные практики обеспечения устойчивого развития муниципальных образований, наделенных статусом наукоградов.

Координация деятельности по развитию муниципальных образований, имеющих статус наукоградов Российской Федерации, осуществляется департаментом инноваций и перспективных исследований Министерства науки и высшего образования Российской Федерации и департаментом регионального развития Министерства экономического развития Российской Федерации [7, 8].

Минобрнауки России проводит политику, направценную на поддержку перспективных проектов в сфере обеспечения комплексного социальноэкономического развития территорий муниципальных образований, надеменных статусом наукоградов. 
В частности, по Распоряжению Министерства науки и высшего образования Российской Федерации от 2 апреля 2021 года № 100-р, государственные субсидии на реализацию перспективных проектов, связанных с организацией высокотехнологичных производств, внедрением аддитивных технологий, созданием современной инфраструктуры в сфере агробиоинженерии будут направлены в наукограды - Мичуринск (Тамбовская обмасть), Комьцово (Новосибирская область), Королев и Пущино (Московская область) [10].

В рамках реализации национальных проектов Российской Федерации "Наука и университеты", "Цифровая экономика" предусмотрено проведение мероприятий, направценных на развитие инновационного потенциала наукоградов, обеспечение перевода научно-производственных комплексов на цифровой фрормат, воспроизводство человеческого капитала и создание необходимых условий для жизни и работы молодых учёных в нашей стране.

Содействие в реализации органами местного самоуправления стратегических ориентиров развития наукоградов, осуществляет "Союз развития наукоградов России" со штаб-квартирой в г. Троицке (Москва).

В каждом из наукоградов, приняты документы стратегического планирования. На средне-срочную перспективу утверждены Стратегии социально-экономического развития гг. Обнинск, Фрязино и Протвино. Стратегические ориентиры развития г. Петергофа заведены в Программу развития Петродворцового района Санкт-Петербурга.

На долгосрочную перспективу приняты Стратегии развития гг. Коромёв, Бийск, Реутов, Жуковский, Мичуринск, Дубна, Троицк, Черноголовка, Пущино, п. Коцьцово. Стратегия социально-экономического развития наукограда Королёв имеет мультимедийную платформу.

При корректировке и формировании документов стратегического планирования на следующий срок, администрации муниципальных образований могут воспоцьзоваться услугами так называемых "конструкторов стратегий и проектов", например, предлагаемых Агентством стратегических инициатив по продвижению новых проектов.

\section{Бибциографический список}

1. Федеральный закон от 7 апреля 1999 года № 70-ФЗ «О статусе наукограда Российской Федерации" // Справочная правовая система "КонсультантПцюс" // Режим доступа : свободный (дата обращения: 18.10.2021).

2. Федеральный закон от 6 октября 2003 года № 131-Ф3 «Об общих принципах организации местного самоуправления в Российской Федерации" // Справочная правовая система "КонсультантПлюс" // Режим доступа : свободный (дата обращения: 18.10.2021).

3. Указ Президента Российской Федерации от 6 мая 2000 года № 821 «О присвоении статуса наукограда Российской Федерации г. Обнинску Калужской области" // URL: http://www.kremlin.ru/acts/bank/15466 // Официальный сайт Президента Российской Федерации // Режим доступа : свободный (дата обращения: 18.10.2021).

4. Агирречу А.А. Наукоград. - Большая Российская энциклопедия // URL: https://bigenc.ru/geography/text/2251786 // Режим доступа свободный (дата обращения: 18.10.2021). 
5. Ааппо Г.М. Города России. Взгляд географа / Г.М. Ааппо. - М.: Новый хронограф, 2021. -504 с.

6. Регионы России. Основные социально-экономические показатели городов. 2020. Стат. сб. / Росстат. - М., 2020. - 456 с.

7. URL: https://www.minobrnauki.gov.ru/about/deps/dipi/naukograd/ Официальный сайт Министерства науки и высшего образования Российской Федерации // Режим доступа : свободный (дата обращения: 16.10.2021).

8. URL: // https://www.economy.gov.ru/material/departments/d14/ Официальный сайт Министерства экономического развития Российской Федерации // Режим доступа : свободный (дата обращения: 16.10.2021).

9. URL: // https://er.ru/activity/news/dmitrij-medvedev-predlozhil-razvivatnauchnye-centry-v-rossii-za-schet-privlecheniya-biznesa - Д.А. Медведев предложим развивать научные центры // Официальный сайт Всероссийской политической партии "Единая Россия" // Режим доступа : свободный (дата обращения: 19.10.2021).

10. URL: //https://www.minobrnauki.gov.ru/press-center/news/?ELEMENT_ $\mathrm{ID}=31953$ // Инновационные проекты наукоградов России // Официальный сайт Минобрнауки РФ // Режим доступа : свободный (дата обращения 16.10.2021).

11. URL: https://adm-sarov.ru/ Официальный сайт администрации г. Caрова / / Режим доступа : свободный (дата обращения: 19.10.2021).

12. URL: https://zhukovskiy.ru/город/history/ Официальный сайт администрации городского округа Жуковский Московской области (дата обращения: 19.10.2021).

13. URL: http://www.raduzhnyi-city.ru/ Официальный сайт администрации ЗАТО г. Радужный Вмадимирской области (дата обращения: 18.10.2021).

ДАя цитирования: Шеркунов С.А. Наукограды России: современное состояние и перспективы развития: статья // Юридическая мысль. - 2021. - № 4 (124). - С. 127-132.

DOI: $10.47905 /$ MATGIP.2021.124.4.015

\section{Russian science cities: current state and development prospects}

\section{Sergey A. Sherkunov*}

Annotation. This article presents a brief reference on the formation and development of science cities in our country; updated information on the population, the main areas of research conducted by scientific organizations and scientific and industrial associations of municipalities endowed with the status of science cities; identified prospects for the development of cities associated with the formation and implementation of projects created using multimedia platform services, strategy designers.

Key words: naukograd, Akademgorodok, the city of the Future, the Union for the Development of Russian Science Cities, the Agency for Strategic Initiatives to Promote New Projects.

* Sherkunov Sergey Aleksandrovich, Deputy Head of the Department of State and Municipal Administration and Law of the Moscow Pedagogical State University; Associate Professor of the Institute of Public Service and Management Russian Academy of National Economy and Public Administration Under the President of the Russian Federation", Candidate of Economic Sciences. E-mail: sa.sherkunov@mpgu.su 
Science city (city of science, during the Soviet period) or technopolis is a municipal entity endowed with the status of an urban district in accordance with Federal Law No. 131-FZ dated October 6, 2003 "On general principles of organizing local self-government in the Russian Federation" [2], a city-forming the base of which is formed by organizations of the scientific and / or scientific-production sphere. Science cities, as a rule, have a developed innovation infrastructure, including industrial parks, engineering centers, business incubators and accelerators.

The first degrees of science appeared in our country in the 1930s 1940s: the town of Zhukovsky (Moscow region), the village of Sarov, now - the town of Sarov on the border of the Gorky (Nizhny Novgorod) region and the Mordovian ASSR (Republic of Mordovia). In 1933, it was decided to establish the Central Aerohydrodynamic Institute on the territory of the modern city of Zhukovsky. At present, the share of workers employed at the enterprises of the scientific and production complex in the city of Zhukovsky is $40.28 \%$ of the total number of people employed in the sectors of the economy [12].

In 1946, the construction of a scientific nuclear center began in the village of Sarov. Today, three academicians of the Russian Academy of Sciences, 109 doctors and 504 candidates of sciences work in scientific organizations and research and production associations in Sarov [11].

In the 1950s-1960s. a course was adopted for the formation of academic towns - satellites of large industrial centers of Siberia - Novosibirsk, Krasnoyarsk, Irkutsk, Tomsk.

With the development of the nuclear industry in the USSR, cities of science appeared in the Penza region (Zarechny), Chelyabinsk region (Ozersk, Snezhinsk (Chelyabinsk-70) and Trekhgorny), Sverdlovsk region (Novouralsk and Lesnoy), Tomsk region (Seversk), Krasnoyarsk Territory (Zheleznogorsk and Zelenogorsk) [4].

Large centers for multidisciplinary research have been established in the Moscow and Kaluga regions. In 1954, in the Kaluga region, the first reactor of the nuclear power plant was launched, which became a city-forming enterprise for the city of Obninsk. On February 25, 1971, the Order of the Council of Ministers of the USSR No. 331-rs was signed on the creation of an Experimental Design Bureau "Raduga" near the city of Vladimir to carry out work on a state defense order [13]. The enterprise has become a city-forming one for the city of Raduzhny, which is currently a large center for laser technologies and has the status of a closed administrative-territorial entity (ZATO).

In the words of G.M. Lappo, cities with high scientific and innovative potential - satellites of the centers of industrial and urban agglomerations in many indicators and properties are "cities of the future" [5, p. 67].

Currently, more than sixty municipalities located in various constituent entities of the Russian Federation claim to be awarded the status of a science city. This status allows the territories to receive a new impetus for development, the formation of points of economic growth, and work on adjusting strategic plans.

Infographics of municipalities with high scientific and technological potential are presented on the platform of the Association of Innovative Regions of Russia and the Agency for Strategic Initiatives to Promote New Projects. 
However, only 14 municipalities located in seven constituent entities of the Russian Federation have the official status of a science city. The first hail of science, which, by the Decree of the Acting President of the Russian Federation V.V. Putin, on May 6, 2000 it was assigned the status of a science city, became the city of Obninsk - the center of the peaceful atom [3]. The summary data on the municipalities endowed with the status of a science city are presented below.

\section{Summary data on municipalities endowed with the status of a science city [6]}

\begin{tabular}{|c|c|c|c|c|c|}
\hline $\begin{array}{l}\mathrm{P} / \mathrm{p} \\
\text { No. }\end{array}$ & $\begin{array}{c}\text { Name } \\
\text { science city }\end{array}$ & $\begin{array}{l}\text { Subject } \\
\text { RF }\end{array}$ & $\begin{array}{l}\text { Date of } \\
\text { assign- } \\
\text { ment } \\
\text { status } \\
\text { (year) }\end{array}$ & $\begin{array}{l}\text { Number of } \\
\text { population } \\
\text { as of } \\
01.01 .2020 \\
\text { (thousand } \\
\text { people) } \\
\end{array}$ & $\begin{array}{l}\text { Specialization, main directions of } \\
\text { research }\end{array}$ \\
\hline 1 & 2 & 3 & 4 & 5 & 6 \\
\hline 1. & Obninsk & $\begin{array}{l}\text { Kaluga } \\
\text { region }\end{array}$ & 2000 & 117,4 & $\begin{array}{l}\text { Multidisciplinary research: } \\
\text { nuclear physics, meteorology } \\
\text { and seismology, chemistry and } \\
\text { pharmaceuticals }\end{array}$ \\
\hline 2. & Dubna & $\begin{array}{l}\text { Moscow } \\
\text { region }\end{array}$ & 2001 & 75,0 & $\begin{array}{l}\text { Nuclear physics; nanotechnol- } \\
\text { ogy }\end{array}$ \\
\hline 3. & Korolev & $\begin{array}{l}\text { Moscow } \\
\text { region }\end{array}$ & 2001 & 225,9 & $\begin{array}{l}\text { Development and production } \\
\text { of rocket and space technolo- } \\
\text { gy; space research }\end{array}$ \\
\hline 4. & Michurinsk & $\begin{array}{l}\text { Tambov } \\
\text { region }\end{array}$ & 2003 & 90,7 & $\begin{array}{l}\text { Breeding, genetics, biochemi- } \\
\text { stry and biotechnology; agroe- } \\
\text { cosystem research }\end{array}$ \\
\hline 5. & Koltsovo & $\begin{array}{l}\text { Novosibirsk } \\
\text { region }\end{array}$ & 2003 & 17,5 & $\begin{array}{l}\text { Virology, Molecular Biology } \\
\text { and Biotechnology }\end{array}$ \\
\hline 6. & Fryazino & $\begin{array}{l}\text { Moscow } \\
\text { region }\end{array}$ & 2003 & 59,5 & $\begin{array}{l}\text { Science-intensive products for } \\
\text { defense purposes; means of } \\
\text { communication; space explora- } \\
\text { tion }\end{array}$ \\
\hline 7. & Reutov & $\begin{array}{l}\text { Moscow } \\
\text { region }\end{array}$ & 2003 & 108,1 & $\begin{array}{l}\text { Development and production of } \\
\text { rocket and space technology }\end{array}$ \\
\hline 8. & Biysk & $\begin{array}{l}\text { Altaic } \\
\text { edge }\end{array}$ & 2005 & 209,2 & $\begin{array}{l}\text { Science-intensive products for } \\
\text { defense purposes; industry of } \\
\text { nanosystems; energy saving } \\
\text { and nuclear power }\end{array}$ \\
\hline 9. & Peterhof & $\begin{array}{c}\text { Saint } \\
\text { Petersburg }\end{array}$ & 2005 & 84,9 & $\begin{array}{l}\text { Multidisciplinary research; small } \\
\text { innovative entrepreneurship }\end{array}$ \\
\hline 10. & Pushchino & $\begin{array}{l}\text { Moscow } \\
\text { region }\end{array}$ & 2005 & 20,7 & Biology; space \\
\hline 11. & Zhukovsky & $\begin{array}{l}\text { Moscow } \\
\text { region }\end{array}$ & 2007 & 107,6 & $\begin{array}{l}\text { Science-intensive products for } \\
\text { defense purposes; information } \\
\text { and telecommunication sys- } \\
\text { tems; transport, aviation and } \\
\text { space systems; energy and } \\
\text { energy saving }\end{array}$ \\
\hline
\end{tabular}


End of the table

\begin{tabular}{|c|c|c|c|c|l|}
\hline 1 & 2 & 3 & 4 & 5 & \multicolumn{1}{|c|}{6} \\
\hline 12. & Troitsk & Moscow & 2007 & 61,0 & $\begin{array}{l}\text { Terrestrial magnetism, high } \\
\text { pressure physics }\end{array}$ \\
\hline 13. & Protvino & $\begin{array}{c}\text { Moscow } \\
\text { region }\end{array}$ & 2008 & 35,4 & $\begin{array}{l}\text { Science-intensive products for } \\
\text { defense purposes; energy con- } \\
\text { servation and nuclear power; } \\
\text { information and telecommuni- } \\
\text { cation systems; security sys- } \\
\text { tems }\end{array}$ \\
\hline 14. & $\begin{array}{c}\text { Cherno- } \\
\text { golovka }\end{array}$ & $\begin{array}{c}\text { Moscow } \\
\text { region }\end{array}$ & 2008 & 21,3 & $\begin{array}{l}\text { Science-based products for de- } \\
\text { fense purposes; physics; che- } \\
\text { mistry; mineralogy; biology }\end{array}$ \\
\hline
\end{tabular}

A special provision - the status quo and the procedure for the implementation of state support for municipalities endowed with the status of science cities of the Russian Federation, is enshrined in the Federal Law of April 7, 1999 No. 70-FZ "On the status of the science city of the Russian Federation" [1]. The development of science cities is in the focus of attention of top officials of the state and federal government bodies. "Science cities and research centers of our country have great potential, as evidenced by the successful development of domestic scientists," said Deputy Chairman of the Security Council of Russia D.A. Medvedev during a meeting on October 13, 2020 on the platform of the All-Russian political party "United Russia". "We should think about a comprehensive system for the development of such centers, including the issues of supporting young scientists and attracting business", D.A. Medvedev [9].

The problems of socio-economic development of science cities are actively discussed during parliamentary hearings, round tables in the Federation Council and the State Duma of the Federal Assembly of the Russian Federation. So, in December 2020, in the Federation Council of the Federal Assembly of the Russian Federation, a round table was held in the videoconference mode, where the best regional practices for ensuring sustainable development of municipalities endowed with the status of science cities were presented.

Coordination of activities for the development of municipalities that have the status of science cities of the Russian Federation is carried out by the Department of Innovation and Advanced Research of the Ministry of Science and Higher Education of the Russian Federation and the Department of Regional Development of the Ministry of Economic Development of the Russian Federation $[7,8]$.

The Russian Ministry of Education and Science pursues a policy aimed at supporting promising projects in the field of ensuring the comprehensive socio-economic development of the territories of municipalities endowed with the status of science cities. In particular, according to the Order of the Ministry of Science and Higher Education of the Russian Federation dated April 2, 2021 No. 100-r, state subsidies for the implementation of promising projects related to the organization of high-tech industries, the introduction of additive technologies, the creation of modern infrastructure in the field of agrobioengineer- 
ing will be directed to science cities - Michurinsk (Tambov region), Koltsovo (Novosibirsk region), Korolev and Pushchino (Moscow region) [10].

As part of the implementation of the national projects of the Russian Federation "Science and Universities", "Digital Economy", it is planned to carry out activities aimed at developing the innovative potential of science cities, ensuring the transfer of scientific and industrial complexes to a digital format, reproducing human capital and creating the necessary conditions for the life and work of young scientists in our country.

Assistance in the implementation by local governments of strategic guidelines for the development of science cities is carried out by the "Union for the Development of Science Cities of Russia" with headquarters in Troitsk (Moscow).

In each of the science cities, strategic planning documents have been adopted. In the mid-term, the strategies of socio-economic development were approved. Obninsk, Fryazino and Protvino. Strategic guidelines for the development of Peterhof are included in the Development Program for the Petrodvorets District of St. Petersburg. For the long term, the Development Strategies were adopted Korolev, Biysk, Reutov, Zhukovsky, Michurinsk, Dubna, Troitsk, Chernogolovka, Pushchino, Koltsovo settlement. The strategy of socio-economic development of the science city of Korolev has a multimedia platform.

When adjusting and drafting strategic planning documents for the next term, municipal administrations can use the services of so-called "strategy and project designers", for example, the Agency's proposed strategic initiatives to promote new projects.

\section{Bibliographic list}

1. Federal Law of April 7, 1999 No. 70-FZ "On the Status of the Science City of the Russian Federation" // Reference legal system "ConsultantPlus". Access mode: free (date of access: 18.10.2021).

2. Federal Law of October 6, 2003 No. 131-FZ "On the General Principles of Organization of Local Self-Government in the Russian Federation" / / Reference legal system "ConsultantPlus". Access mode: free (date of access: 18.10.2021).

3. Decree of the President of the Russian Federation of May 6, 2000 No. 821 "On assigning the status of a science city of the Russian Federation to Obninsk, Kaluga Region" // URL: http://www.kremlin.ru/acts/bank/15466. Official site of the President of the Russian Federation. Access mode: free (date of access: 18.10.2021).

4. Agirrechu A.A. Science city. Great Russian Encyclopedia // URL: https:// bigenc.ru/geography/text/2251786. Free access (date of access: 18.10.2021).

5. Lappo G.M. Cities of Russia. Geographer's view / G.M. Lappo. Moscow: New Chronograph, 2021. 504 p.

6. Regions of Russia. The main socio-economic indicators of cities. 2020. Stat. Sat. / Rosstat. Moscow, 2020. 456 p.

7. URL: https://www.minobrnauki.gov.ru/about/deps/dipi/naukograd/ Official site of the Ministry of Science and Higher Education of the Russian Federation. Access mode: free (date of access: 16.10.2021).

8. URL: https://www.economy.gov.ru/material/departments/d14/ Official website of the Ministry of Economic Development of the Russian Federation. Access mode: free (date of access: 16.10.2021). 
9. URL: https://er.ru/activity/news/dmitrij-medvedev-predlozhil-razvivatnauchnye-centry-v-rossii-za-schet-privlecheniya-biznesa. D.A. Medvedev suggested developing research centers. - The official site of the All-Russian political party "United Russia". Access mode: free (date of access: 19.10.2021).

10. URL: https://www.minobrnauki.gov.ru/press-center/news/?ELEMENT_ID = 31953 - Innovative projects of Russian science cities. Official site of the Ministry of Education and Science of the Russian Federation. Access mode: free (date of access 10/16/2021).

11. URL: https://adm-sarov.ru/ - Official site of the Sarov city administration. Access mode: free (date of access: 19.10.2021).

12. URL: https://zhukovskiy.ru/city/history/ Official website of the administration of the urban district Zhukovsky, Moscow region (date of access: 19.10.2021).

13. URL: http://www.raduzhnyi-city.ru/ The official website of the administration of the closed administrative district of the city of Raduzhny, Vladimir region (date of access: 18.10.2021).

For citation: Sherkunov S.A. Science cities of Russia: current state and development prospects: article // Legal thought. 2021. No. 4 (124). P. 132-137.

DOI: 10.47905 / MATGIP.2021.124.4.015

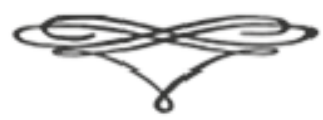




\title{
5.1.4. УГОАОВНО-ПРАВОВЫЕ НАУКИ
}

\author{
(12.00.08 - Уголовное право \\ Н крнмннологня;

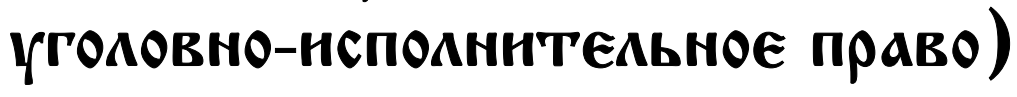

удк 343

ББК 67.0

DOI: $10.47905 /$ MATGIP.2021.124.4.011

\author{
УГОАОвно-ПРАвОвОе вОЗАЕЙСТВНЕ: \\ ПОнятнЕ н ПрАвОВАя ПрнрОАа
}

\begin{abstract}
M.Ф. Гареєв*
Аннотация. В данной статье исследуются меры уголовно-правового воздействия, раскрываются их правовая природа и особенности. Осуществлена демонстрация ошибочного подхода законодателя к дифференциации мер уголовноправового воздействия. Предлагается авторская версия дифференциации мер уголовно-правового воздействия в уголовном законодательстве: наказание и иные меры уголовно-правового характера, а также меры уголовно-правового характера, посредством которых не реализуется уголовная ответственности. Выдвигается авторский вариант опредемения мер уголовно-правового воздействия.

К^ючевые слова: уголовное законодательство, уголовно-правовое воздействие, предупреждение преступлений, уголовная ответственность, наказание, иные меры уголовно-правового характера, принудительные меры медицинского характера, дифференциация мер уголовно-правового воздействия.
\end{abstract}

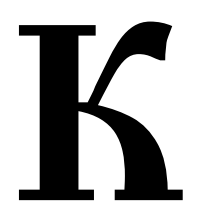

фундаментальным категориям уголовного права относится угомовно-правовое воздействие, которое пронизывает практически все ее институты и нормы. Обращение к филологическим аспектам указывает, что понятие "воздействие" или "воздействовать" означает как "оказать вмияние, добиться (ими добиваться) необходимого результата" [12, с. 92]. Понятие "мера" в этом же контексте обозначается как "граница, предел проявцения чего-нибудь, а также как средство дмя осуществления чего-нибудь" [12, с. 92].

Основным предназначением мер уголовно-правового воздействия, как это следует из положений ст. 2 УК РФ, является охрана наиболее значимых общественных отношений и предупреждение преступной деятемьности [1]. Исходя из положений данной нормы уголовного закона, к ключевой задаче

* Гареев Maрат Фаизович, доцент кафедры уголовного права и процесса Юридического института (Санкт-Петербург), кандидат юридических наук, доцент. E-mail: gareeff. marat2013@yandex.ru 
законодателя и правоприменителя относится разработка средств и методов

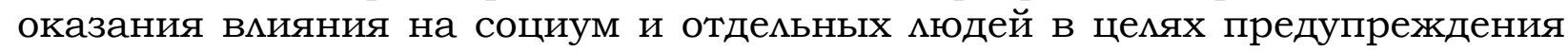
преступной деятельности. Множественные индивидуамьные различия, обусловленные разцичными факторами, включая социальные и психологиче-

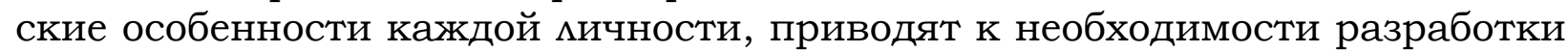
и назначения судом разцичных по своей интенсивности мер уголовноправового характера.

Выбор интенсивности мер уголовно-правового воздействия в значительной степени зависит от характера и степени общественной опасности

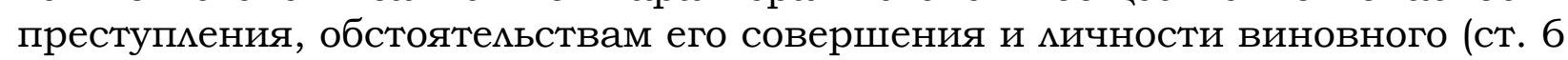
УК РФ) [1].

Как следует из разъяснений Постановления Пленума Верховного Суда РФ от 22 декабря 2015 г. № 58 «О практике назначения судами Российской Федерации угомовного наказания", характер и степень опасности преступмения определяются уголовным законом и зависят от установленных судом признаков состава преступления. При учете характера общественной опасности преступления судам следует иметь в виду, прежде всего, направценность деяния на охраняемые уголовным законом социальные ценности и причиненный им вред [3].

Степень общественной опасности преступления устанавливается судом в зависимости от конкретных обстоятецьств содеянного. К ним относятся характер и размер наступивших последствий, способ совершения преступмения, роли подсудимого в преступлении, совершенном в соучастии, от вида умысла (прямой или косвенный) мибо неосторожности (Аегкомыслие или небрежность). Учету подмежат обстоятельства, смягчающие или отягчающие наказание и относящиеся к совершенному преступлению (например, совершение преступления в силу стечения тяжелых жизненных обстоятельств, Аибо по мотиву сострадания, особо активная роль в совершении преступцения) [3].

Положения ст. 6 УК РФ и данные разъяснения высшего органа судебной власти свидетельствуют о необходимости применения наименышей интен-

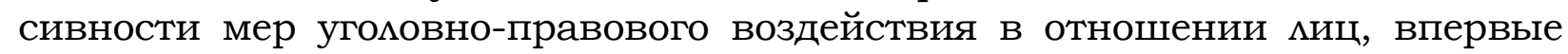
совершивших преступления, относящиеся к категории небольшой и средней тяжести. Для них достаточно привлечения к уголовной ответственности и применения, незначительных по силе воздействия, мер уголовно-процессуального принуждения, например, подписка о невыезде и надмежащем поведении, которое, в итоге, может завершиться прекращением производства по уголовному делу и освобождением от уголовной ответственности, в частности, по таким основаниям, как деятельное раскаяние или в связи с примирением с потерпевшим (ст. ст. 75, 76 УК РФ) [1]. Применение незначительных по своей интенсивности мер уголовно-правового воздействия для отдельных категорий миц, впервые совершивших преступления небольшой и средней тяжести, может способствовать выполнению предупредительной задачи уголовного законодательства и отбить у них желание в дальнейшем заниматься преступной деятемьностью.

В отношении других миц, которые совершили преступления, относящиеся к категории тяжких и особо тяжких, домжны быть применены более 
строгие меры уголовно-правового воздействия, поскольку сам факт совершения таких преступлений свидетельствует о наличии устоявшихся отрицательных морально-нравственных установок мичности. В подобных случаях меры уголовно-правового воздействия могут выражаться в виде наказания, влекущего не только ограничение прав и свобод осужденного, но их мишение. К ним могут быть применены такие виды наказания как мише-

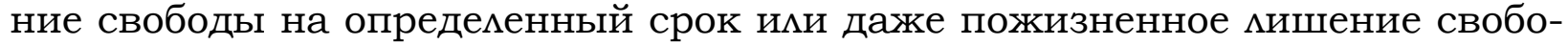
ды в случае посягательства на жизнь нескольких человек.

Из разъяснений вышеуказанного Постановцения Пленума Верховного Суда РФ следует, что к сведениям о мичности, подмежащим учету при назначении наказания, относятся характеризующие виновного сведения, которыми располагает суд при вынесении приговора. K таковым могут, в частности, относиться данные о семейном и имущественном положении совершившего преступление мица, состоянии его здоровья, поведении в быту, наличии у него на иждивении несовершеннолетних детей, иных нетрудоспособных миц (супругов, родителей, других близких родственников) [3].

Столь широкий спектр мер уголовно-правового воздействия, начиная от освобождения от уголовной ответственности и заканчивая применением

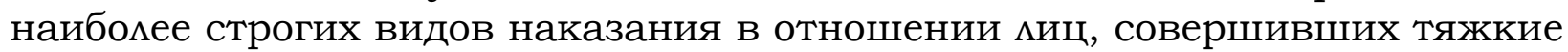
или особо тяжкие преступцения, свидетельствует об их обширности и вариативности.

Следуя основным предписаниям ст. 2 УК РФ [1], направленным на предупреждение преступных деяний, надо заметить, что уголовно-правовое воздействие не ограничивается рамками уголовно-правовых отношений, а охватываются другими отраслями права. На данное обстоятельство обращено внимание в митературе.

По мнению Н.А. Аопашенко уголовно-правовое воздействие "охватывает сразу и уголовное право, и уголовное законодательство, и уголовно-правовую политику как основополагающие элементы, аккумулирующие в себя понятия преступного и наказуемого и все, что с ними связано" [13, с. 7].

Под уголовно-правовым воздействием С.В. Векленко понимает "специальную деятельность государства по защите наиболее важных дмя общества отношений от преступных посягательств и регулированию тех отношений, которые возникают вследствие нарушения устанавциваемых им уголовно-правовых запретов" [5, с. 370].

С точки зрения В.К. Дуюнова, уголовно-правовое воздействие - это специальная деятельность государства, реагирующего на факты нарушения устанавливаемых им уголовно-правовых запретов посредством использования возможностей, заложенных в уголовном праве [10, с. 28].

Анализ различных подходов в научном сообществе демонстрирует тот факт, что в основном они акцентируют внимание на мерах уголовноправового воздействия, связанных с реализацией уголовной ответственности и, соответственно, их диффреренцируют с этих позиций, относя к ним наказание и иные меры уголовно-правового характера $[4 ; 18$, с. 55].

Аналогичной позиции придерживаются А.И. Чучаев и А.П. Фирсова. По их мнению, мерой уголовно-правового воздействия явцяется "мера государственного принуждения, назначаемая судом мицу, совершившему об- 
щественно опасное деяние, и заключающаяся в предусмотренных настоящим Кодексом мишении ими ограничении свободы этого мица" [18, с. 55].

Подобные позиции исследователей обусловлены как положениями ч. 2 ст. 43 УК РФ [1], установившей, что одной из цемей наказания явцяется предупреждение преступлений, так и иными нормами Общей части УК РФ, регламентировавшими иные меры уголовно-правового характера, направменные на достижение превентивной цели уголовного законодательства.

Однако предупредительная задача уголовного законодательства не ограничивается только рамками достижения целей наказания и иных мер уголовно-правового характера. Дия общества и государства наиболее будет предпочтительным, когда предупредительная задача уголовного закона, установленная ст. 2 УК РФ [1], будет реализовываться не только в отношении миц, совершивших преступление, но в отношении неопределенного круга граждан, склонных к совершению преступных деяний. В уголовном праве оно именуется общей превенцией, имевшей широкое распространение в советском уголовном законодатецьстве.

В прежнем УК РСФСР 1960 г. общая превенция была законодательно закреплена в ст. 20 УК РФ и выступала в качестве цели наказания. В ныне действующем УК РФ данная цель законодательно не предусмотрена, но она подразумевается (ч. 2 ст. 43 УК РФ) [1].

Достижение общей превенции, как задачи уголовного законодательства, представцяется возможным осуществить не только и даже не столько в рамках уголовно-правовых и близких с ним правоотношений (уголовнопроцессуальных, уголовно-исполнительных), а и в рамках других отраслей права, затрагивающих более широкий круг общественных отношений, призванных создать благоприятную основу дия правомерного поведения. Такого рода подход дия общества и государства является наиболее предпочтительным, поскольку мегче предотвратить преступную деятельность, чем пожинать ее последствия. Особенно это актуально дмя наиболее ценных социальных благ, таких, например, как жизнь и здоровье мюдей.

О возможности предотвращения преступлений, относящихся к категории особо тяжких, посягающих на жизнь мюдей, свидетельствуют даже обстоятельства трагедии, происшедшее 11 мая 2021 г. в школе № 175 г. Казань Республики Татарстан, когда бывший ее ученик Ильназ Галявиев совершиц убийство девяти учеников и двух учителей. Более двух десятков детей получими ранения размичной степени тяжести [14, 17].

Предупреждение подобного рода преступлений, вцекущих трагические последствия, представляется возможным в случае выполнения комплексных мер по их предупреждению, выходящих далеко за пределы угомовно-правовых отношений.

Создание благоприятных условий дмя устранения причин совершения преступных деяний можно отнести к одной из мер уголовно-правового воздействия, направленных на достижение предупредительной задачи угомовного законодатецьства, установленная ст. 2 УК РФ [1]. Подобные выводы соответствуют не только предупредительным задачам уголовного законодательства, но и концепции позитивной уголовной ответственности, суть которой также сводится к устранению причин преступной деятельности и соз- 
данию благоприятных условий для правомерного поведения чменов общества. Концепция позитивной уголовной ответственности освещается, в частности, такими учеными, как Елеонский, Б.В. Сидоров, С.А. Велиев и др. $[6$, с. $95 ; 11$, с. $29 ; 16$, с. 124$]$.

Вышеизложенное свидетемьствуют о необходимости вкцючения в $е$ гальное определение "меры уголовно-правового воздействия" условий, способствующих правомерному поведению и закреплению данного понятия в уголовном законодательстве. В связи с тем, что меры уголовно-правового воздействия относятся к фундаментальным, предлагается автором данной публикации закрепить ее определение в ст. $2^{1}$ УК РФ с соответствующим названием [1].

В определенной степени достижению предупредительной задачи угомовного законодательства (ст. 2 УК РФ) [1] способствуют меры уголовноправового воздействия, направценные на освобождение от уголовной ответственности, которые можно условно обозначить как меры уголовно-правового характера, чтобы отграничить от иных мер уголовно-правового характера, выступающие разновидностями реализации уголовной ответственности.

Отдельное внимание заслуживает институт освобождения от уголовной ответственности. Например, к ним относится деятельное раскаяние и примирение с потерпевшим (статьи 75 и 76 УК РФ) [1], предусматривающее, что мицо, совершившее преступцение небольшой или средней тяжести, устраняет не только последствия преступного деяния, заключающееся в возмещении ущерба или заглаживания вреда, но оно также должно испытывать правоограничения. В силу предписаний ряда норм уголовно-процессуального законодательства, такое мицо подвергается принудительным мерам, направленным на ограничение его прав и свобод в связи с производством по уголовному делу. K ним могут быть отнесены такие меры, как обязанность являться по вызову суда, следователя, дознавателя дмя производства следственных и процессуальных действий, избрание меры пресечения в виде подписке о невыезде и надлежащем поведении и т.д.

По сравнению с мерами уголовно-процессуального принуждения, закАючающимися, по сути, в мишение ряда свобод гражданина (например, избрание меры пресечения в виде заключения под стражу или домашний

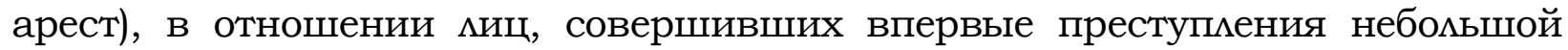
или средней тяжести, будет не только избыточным, но и социально вредным.

Основным предназначением института освобождения от уголовной ответственности является возможность применения наименее интенсивных мер уголовно-правового воздействия, которые, по мнению законодате$\Lambda я$, представцяются наиболее оптимальными. В свою очередь, применение

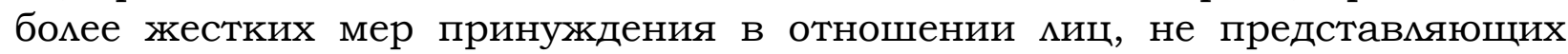
значитемьной общественной опасности, может негативным образом отразиться не только на мице, совершившем преступное деяние, но в состоянии вызвать в обществе чувство несправедливости, которое отобьет желание

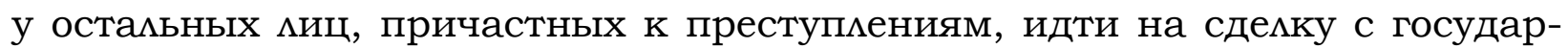
ством, не получая взамен снисхождения.

Реализация мер уголовно-процессуального принуждения (особенно

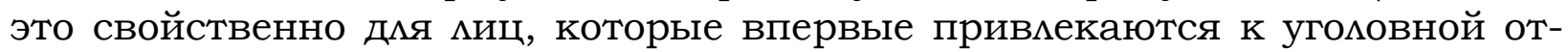


ветственности) приводят к положительным психологическим изменениям мичности, направленным на формирование правомерного поведения, обусловленного страхом перед наказанием и процедурой правоограничений, установленных уголовно-процессуальным законодательством.

Применение положений уголовного законодательства, направленные на устранение преступных последствий (ст. ст. 75, 76, 761, 76² УК РФ) [1], в совокупности с правоограничениями, установленными уголовно-процессуальным законодательством, способствуют достижению предупредительных задач уголовного законодательства и говорят о комплексном характере мер уголовно-правового воздействия.

Анализ уголовного законодательства и иных отраслей права свидетельствует, что меры уголовно-правового воздействия не ограничиваются только мерами принудительного характера, в том числе меры, посредством которых реализуется уголовная ответственность. Как уже было отмечено, к мерам уголовно-правового воздействия следует отнести меры, направленные на создание благоприятных условий, способствующих правомерному поведению, которые преимущественно не являются мерами принуждения.

Реализация мер уголовно-правового воздействия, посредством которых не реализуется уголовная ответственность, может осуществцяться не только судом, но и следователем с согласия руководителя следственного органа или дознавателя с согласия прокурора. Данные полномочия субъектов уголовно-процессуальных отношений со стороны обвинения предусмотрены положениями ст. 25 УПК РФ, предоставляющие им право прекратить производство по уголовному делу в связи с примирением сторон [2].

Несколько иную правовую природу имеют принудительные меры медицинского характера, назначаемые за совершенное преступное (общественно опасное) деяние. Как ранее автором отмечалось, данные меры с одной стороны, выступают в качестве иной меры уголовно-правового характера, явцяющиеся одной из разновидностей реализации уголовной ответственности, назначаемые мицам, совершившим преступление и страдающим психическими расстройствами, не исключающими вменяемости, и в отношении миц, страдающих педофилией (пункты “В” и "д" ч. 1 ст. 97 УК РФ),

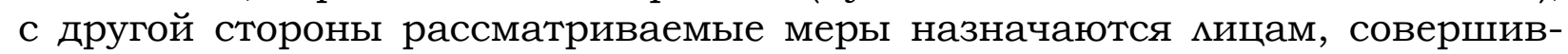
шим общественно опасное деяние в состоянии невменяемости и мицам, ставшими таковыми после совершения преступления (пункты “а" и "б" ч. ст. 97 УК РФ) [1; 7; 8].

Наряду с достижением цели, направленной на предупреждение новых общественно опасных деяний в ст. 98 УК РФ, целями принудительных мер медицинского характера является измечение или улучшение психиче-

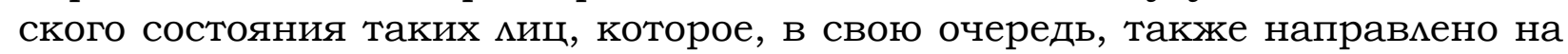
достижение предупредительных задач уголовного законодательства (ст. 2 УК РФ) [1]. Несмотря на то, что цель измечения или улучшения психического состояния мица, совершившего общественно опасное деяние, выдемена в ст. 98 УК РФ отдельно [1], оно также направлено на достижение предупредительных задач уголовного законодательства.

Проведенный выше анализ уголовного законодательств и разцичных подходов, имеющих место в уголовно-правовой митературе (включая пред- 
можения автора данной публикации), меры уголовно-правового характера следовало бы раздемить на: 1) наказание, выступающее основной формой реализации уголовной ответственности; 2) иные меры уголовно-правового характера, являющиеся альтернативной формой реализации уголовной ответственности и по сравнению с наказанием, обладающие меньшей интен-

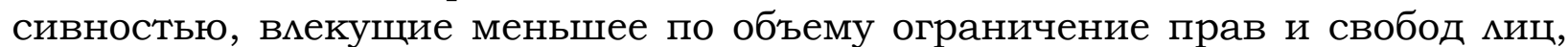
совершивших преступные деяния; 3) меры уголовно-правового характера, посредством которых уголовная ответственность не реализуется.

Предложенная выше дифференциация мер уголовно-правового воздействия имеет в значительной степени концептуальный характер и получимо отражение только в теории уголовного права, поскольку законодатель к иным мерам уголовно-правового характера ошибочно отнес принудительные меры медицинского характера, назначаемые в отношении $\Lambda$ и, совершивших общественно опасное деяние в состоянии невменяемости. Оно обусловлено тем, что принудительные меры медицинского характера, назначаемые в отношении невменяемых, по своей правовой природе не относятся к альтернативным формам реализации уголовной ответственности. Данные выводы подтверждаются положениями ч. 1 ст. 21 УК РФ, в котором указано, что мица, совершившие общественно опасные деяния, не подмежат уголовной ответственности [1].

$\mathrm{K}$ ошибочным решениям законодателя также следует отнести правовую регламентацию раздела VI УК РФ «Иные меры уголовно-правового характера", где ограничился включением в нее только принудительных мер медицинского характера, конфискации имущества и судебного штрафа. В то же время положения ст. 3, ч. 1 ст. 6, ч. 2 ст. 7 УК РФ [1] и ряд других норм уголовного закона указывают о широком разнообразии альтернативных форм реализации уголовной ответственности. В частности, к ним относятся условное осуждение (ст. 73 УК РФ), отсрочка по правилам ст. 82 УК РФ, принудительные меры воспитательного воздействия, а также другие формы реализации уголовной ответственности, предусмотренные уголовным законодательством. Ранее проблема регламентации мер уголовноправового воздействия поднималась автором в других публикациях [9, с. 12].

В настоящее время, очевидно, что введение регламентации мер угомовно-правового воздействия в соответствии со своей правовой природой является сомнительной, поскольку в состоянии вызвать путаницу в правоприменительной практике и нанести куда больший вред. По этой причине регламентация мер уголовно-правового воздействия представляется возможной в ходе разработки и принятия нового УК РФ, необходимость которого назрела давно [15.]

В качестве итога проведенного исследования автор предлагает дать следующее определение мерам уголовно-правового воздействия, указав, что ею является мера государственного принуждения, назначаемая судом

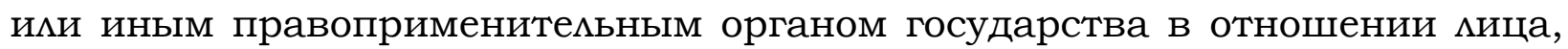
совершившего преступление или общественно опасное деяние невменяе-

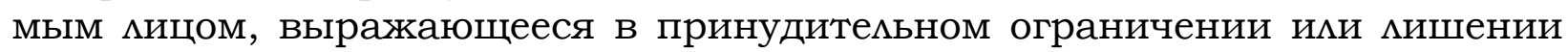
его прав и свобод, а также правоприменение мер и средств, направленных на предупреждение преступных (общественно опасных) деяний. 
Таким образом, предиагаемое определение отражает правовую природу мер уголовно-правового воздействия, свидетельствует о ее комплексном характере, которое не должно ограничиваться уголовно-правовыми и близкими с ними правовыми отношения, и в необходимости разработки законодателем мер, направленных на предупреждение преступной деятельности.

\section{Бибмиографический список}

1. «Уголовный кодекс Российской Федерации» от 13.06.1996 № 63-Ф3 (ред. от 01.07.2021) // www.consultant.ru

2. “Уголовно-процессуальный кодекс Российской Федерации» от 18.12.2001 № 174-Ф3 (ред. от 01.07.2021, с изм. от 23.09.2021) // www.consultant.ru

3. Постановцение Пленума Верховного Суда РФ от 22 декабря 2015 г. № 58 "О практике назначения судами Российской Федерации уголовного наказания" // Бюмметень Верховного Суда РФ. 2016. № 2.

4. Бавсун М.В. Уголовно-правовое воздействие: идеология, цели и средства и реализации: дисс. док... юрид. наук. - Омск, 2013. - 396 с.

5. Векленко С.В. О повышении эффективности угоцовно-правового воздействия //Противодействие преступности: уголовно-правовые, криминологические и уголовно-исполнительные аспекты: материалы III российского конгресса уголовного права (29 мая - 30 мая 2008 г.). - М., 2008. - 736 с.

6. Велиев С.А. Общее понятие и значение уголовной ответственности // "Черные дыры” в Российском законодательстве. - Юридический журнал. - 2004. № 1. - C. 94-101.

7. Гареев М.Ф. Альтернативы в уголовном праве: отдельные аспекты. // Юридическая мысль. - 2019. - № 6. - С. 82-95.

8. Гареев М.Ф. Некоторые вопросы регламентации принудительных мер медицинского характера как иной меры уголовно-правового характера. // Современная уголовная политика: поиск оптимальной модели. Материалы VII Российского конгресса уголовного права (31 мая - 1 июня 2012 г.). /Отв. ред. В.С. Комиссаров. - М.: Проспект, 2012. - С. 37-39.

9. Гареев М.Ф. Цели иных мер уголовно-правового характера и средства их достижения по российскому уголовному праву: дисс. канд. ... юрид. наук. - Казань, 2005. - 198 с.

10. Дуюнов В.К. Уголовно-правовое воздействие: теория и практика. - М., 2003. -520 c.

11. Елеонский В.А. Уголовное наказание и воспитание позитивной ответственности Аичности. - Рязань, 1979. - 83 с.

12. Ожегов С.И. и Шведова Н.Ю. Толковый словарь. //Российская академия наук. Институт русского языка им. В.В. Виноградова. - 4-е изд., дополненное. М.: ООО "ИТИ Технология", 2006. - С. 92.

13. Аопашенко Н.А. Основы уголовно-правового воздействия: уголовное право, уголовный закон, уголовно-правовая политика. - СПб., 2004. - 339 с.

14. Стрельба в Казани обрастает фигурантами - Происшествия - Коммерсантъ. [Электронный ресурс] //Режим доступа: https://www.kommersant.ru/doc/ 4889901 (дата обращения - 30 августа 2021 г.);

15. Современная уголовная политика: поиск оптимальной модели. Материамы VII Российского конгресса уголовного права (31 мая - 1 июня 2012 г.). /Отв. ред. В.С. Комиссаров. - М.: Проспект, 2012. - 664 с.

16. Уголовное право России. Общая часть. Под ред. Ф.Р. Сундурова. - Казань: Издательство Казанского университета, 2003. - 648 с. 
17. Хронология расстрела: можно ми было предотвратить трагедию в Казани. [Электронный ресурс] //Режим доступа: https:ren.tv/criminal/832875 (дата обращения - 30 августа 2021 г.).

18. Чучаев А.И., Фирсова А.П. Уголовно-правовое воздействие: понятие, объект, механизм, классификация: монография - М.: Проспект, 2010 - 320 с.

Дия цитирования: Гареев М.Ф. Уголовно-правовое воздействие: понятие и правовая природа: статья // Юридическая мысль. - 2021. - № 4 (124). - С. 138-146.

DOI: $10.47905 /$ MATGIP.2021.124.4.011

\section{Criminal law impact: concept and legal nature}

\section{Marat F. Gareev *}

Annotation. This article examines the measures of criminal law impact, reveals their legal nature and features. The demonstration of the legislator's erroneous approach to the differentiation of measures of criminal law is carried out. The author's version of the differentiation of measures of criminal-legal influence in criminal legislation is proposed: punishment and other measures of a criminal-legal nature, as well as measures of a criminal-legal nature, through which criminal liability is not implemented. The author's version of the definition of measures of criminal law is put forward.

Key words: criminal legislation, criminal law impact, crime prevention, criminal liability, punishment, other criminal law measures, compulsory medical measures, differentiation of criminal law measures.

The fundamental categories of criminal law include criminal law impact, which permeates almost all of its institutions and norms. An appeal to the philological aspects indicates that the concept of "impact" or "influence" means how to "influence, achieve (or achieve) the desired result" [12, p. 92]. The concept of "measure" in the same context is designated as "the border, the limit of the manifestation of something, and also as a means for the implementation of something" [12, p. 92].

The main purpose of measures of criminal law impact, as follows from the provisions of Art. 2 of the Criminal Code of the Russian Federation, is the protection of the most significant public relations and the prevention of criminal activity [1]. Based on the provisions of this provision of the criminal law, the key task of the legislator and law enforcement officer is the development of means and methods of influencing society and individuals in order to prevent criminal activity. Multiple individual differences due to various factors, including the social and psychological characteristics of each person, lead to the need to develop and appoint by the court measures of a criminal-legal nature that are different in intensity.

The choice of the intensity of measures of criminal law influence to a large extent depends on the nature and degree of social danger of the crime, the cir-

* Gareev Marat Faizovich, associate professor of the Law Institute (St. Petersburg), candidate of legal sciences. E-mail: gareeff.marat2013@yandex.ru 
cumstances of its commission and the personality of the perpetrator (Article 6 of the Criminal Code of the Russian Federation) [1].

As follows from the clarifications of the Resolution of the Plenum of the Supreme Court of the Russian Federation of December 22, 2015 No. 58 "On the practice of imposing criminal punishment by the courts of the Russian Federation", the nature and degree of danger of the crime are determined by the criminal law and depend on the signs of corpus delicti established by the court. When taking into account the nature of the social danger of the crime, the courts should bear in mind, first of all, the direction of the act on the social values protected by the criminal law and the harm caused to them [3].

The degree of social danger of a crime is established by the court depending on the specific circumstances of the offense. These include the nature and size of the consequences that have occurred, the method of committing the crime, the role of the defendant in a crime committed with complicity, from the type of intent (direct or indirect) or negligence (frivolity or negligence). Consideration should be given to circumstances that mitigate or aggravate the punishment and relate to the crime committed (for example, the commission of a crime due to a combination of difficult life circumstances, or on the basis of compassion, a particularly active role in the commission of a crime) [3].

The provisions of Art. 6 of the Criminal Code of the Russian Federation and these explanations of the highest judicial authority indicate the need to apply the lowest intensity of measures of criminal law in relation to persons who first committed crimes belonging to the category of small and medium severity. For them, it is enough to bring to criminal liability and the use of measures of criminal procedural coercion that are insignificant in terms of impact, for example, a written undertaking not to leave the place and proper behavior, which, as a result, may result in the termination of criminal proceedings and release from criminal proceedings responsibility, in particular, on such grounds as active repentance or in connection with reconciliation with the victim (Articles 75, 76 of the Criminal Code of the Russian Federation) [1]. The use of measures of criminal law, insignificant in their intensity, for certain categories of persons who have committed crimes of small and medium severity for the first time, can contribute to the implementation of the preventive task of criminal legislation and discourage them from further engaging in criminal activity.

In relation to other persons who have committed crimes belonging to the category of grave and especially grave, stricter measures of criminal law should be applied, since the very fact of committing such crimes indicates the presence of well-established negative moral and ethical attitudes of the individual ... In such cases, the measures of criminal law can be expressed in the form of a punishment, entailing not only the restriction of the rights and freedoms of the convicted person, but their deprivation. Such types of punishment as imprisonment for a certain period or even life imprisonment in case of encroachment on the life of several people can be applied to them.

From the explanations of the above Resolution of the Plenum of the Supreme Court of the Russian Federation, it follows that the information about the person, subject to registration when imposing a sentence, includes infor- 
mation characterizing the guilty person, which the court has at the sentencing. These may, in particular, include data on the family and property status of the person who committed the crime, his state of health, behavior in everyday life, whether he has minor children or other disabled persons (spouses, parents, other close relatives) as his dependents [3].

Such a wide range of measures of criminal law, ranging from exemption from criminal liability and ending with the application of the most severe types of punishment in relation to persons who have committed grave or especially grave crimes, testifies to their vastness and variability.

Following the basic requirements of Art. 2 of the Criminal Code of the Russian Federation [1], aimed at preventing criminal acts, it should be noted that the criminal law impact is not limited to the framework of criminal law relations, but is covered by other branches of law. Attention is drawn to this circumstance in the literature.

According to N.A. Lopashenko, the criminal law impact "immediately encompasses both criminal law, and criminal law, and criminal law policy as fundamental elements that accumulate the concepts of the criminal and the punishable and everything connected with them" [13, p. 7].

Under criminal law influence S.V. Veklenko understands "the special activity of the state to protect the most important relations for society from criminal encroachments and regulate those relations that arise as a result of violation of the criminal-legal prohibitions established by him" [5, p. 370].

From the point of view of V.K. Duyunov, criminal law influence is a special activity of the state that responds to the facts of violation of the criminal law prohibitions established by it through the use of the possibilities inherent in criminal law [10, p. 28].

The analysis of various approaches in the scientific community demonstrates the fact that they mainly focus on the measures of criminal law impact associated with the implementation of criminal liability and, accordingly, they are differentiated from these positions, referring to them punishment and other measures of criminal law character [4; 18, p. 55].

According to A.I. Chuchaev and A.P. Firsova, the measure of criminal law is "a measure of state coercion, appointed by the court to a person who has committed a socially dangerous act, and consisting in the deprivation or restriction of the freedom of this person provided for by this Code" [18, p. 55].

Such positions of researchers are due to both the provisions of Part 2 of Art. 43 of the Criminal Code of the Russian Federation [1], which established that one of the purposes of punishment is the prevention of crimes, and other norms of the General Part of the Criminal Code of the Russian Federation, regulating other measures of a criminal-legal nature aimed at achieving the preventive goal of criminal legislation.

However, the preventive task of criminal legislation is not limited only to the framework of achieving the goals of punishment and other measures of a criminal-legal nature. For society and the state, it will be most preferable when the preventive task of the criminal law, established by Art. 2 of the Criminal Code of the Russian Federation [1], will be implemented not only in relation to persons who have committed a crime, but in relation to an indefinite circle of 
citizens prone to committing criminal acts. In criminal law, it is called general prevention, which was widespread in Soviet criminal law.

In the former Criminal Code of the RSFSR in 1960, general prevention was legislatively enshrined in Art. 20 of the Criminal Code of the Russian Federation and acted as the target of punishment. In the current Criminal Code of the Russian Federation, this goal is not legally stipulated, but it is implied (part 2 of Art. 43 of the Criminal Code of the Russian Federation) [1].

Achieving general prevention, as a task of criminal legislation, is possible to carry out not only and even not so much within the framework of criminal law and close legal relations with it (criminal procedure, criminal executive), but also within the framework of other branches of law affecting more a wide range of social relations designed to create a favorable basis for lawful behavior. This kind of approach is the most preferable for society and the state, since it is easier to prevent criminal activity than to reap its consequences. This is especially true for the most valuable social benefits, such as, for example, the life and health of people.

Even the circumstances of the tragedy that took place on May 11, 2021 at school No. 175 in Kazan, the Republic of Tatarstan, when her former student Ilnaz Galyaviev murdered nine students and two teachers. More than two dozen children were injured of varying severity [14, 17].

Prevention of this kind of crimes, entailing tragic consequences, is possible if comprehensive measures are taken to prevent them, which go far beyond the boundaries of criminal law relations.

The creation of favorable conditions for eliminating the causes of the commission of criminal acts can be attributed to one of the measures of criminal law aimed at achieving the preventive task of criminal legislation, established by Art. 2 of the Criminal Code of the Russian Federation [1]. Such conclusions correspond not only to the preventive tasks of criminal legislation, but also to the concept of positive criminal liability, the essence of which also boils down to eliminating the causes of criminal activity and creating favorable conditions for the lawful behavior of members of society. The concept of positive criminal liability is highlighted, in particular, by such scientists as Eleonsky, B.V. Sidorov, S.A. Veliev and others [6, p. 95; 11, p. 29; 16, p. 124].

The foregoing testifies to the need to include in the legal definition of the "measure of criminal law impact" conditions conducive to lawful behavior and the consolidation of this concept in criminal legislation. Due to the fact that the measures of criminal law are fundamental, the author of this publication is invited to consolidate its definition in Art. 21 of the Criminal Code of the Russian Federation with the appropriate name [1].

To a certain extent, the achievement of the preventive task of the criminal legislation (Art. 2 of the Criminal Code of the Russian Federation) [1] is facilitated by measures of criminal law aimed at exemption from criminal liability, which can be conditionally designated as measures of a criminal law nature in order to delimit from other measures of a criminal-legal nature, acting as varieties of the implementation of criminal liability.

The institution of exemption from criminal liability deserves special attention. For example, these include active repentance and reconciliation with 
the victim (Articles 75 and 76 of the Criminal Code of the Russian Federation) [1], which provides that a person who has committed a crime of small or medium gravity eliminates not only the consequences of a criminal act, consisting in compensation for damage or making amends harm, but it must also be subject to legal restrictions. By virtue of the prescriptions of a number of norms of the criminal procedural legislation, such a person is subjected to coercive measures aimed at restricting his rights and freedoms in connection with criminal proceedings. These may include such measures as the obligation to appear when summoned by the court, the investigator, the interrogator to carry out investigative and procedural actions, the choice of a preventive measure in the form of a recognizance not to leave the place and proper behavior, etc.

Compared to the measures of criminal procedural coercion, which, in fact, include the deprivation of a number of freedoms of a citizen (for example, the election of a preventive measure in the form of detention or house arrest), in relation to persons who have committed the first time crimes of small or medium gravity, there will be not only redundant, but also socially harmful.

The main purpose of the institution of exemption from criminal liability is the possibility of applying the least intensive measures of criminal law influence, which, in the opinion of the legislator, seem to be the most optimal. In turn, the use of more stringent coercive measures against persons who do not pose a significant public danger can negatively affect not only the person who has committed a criminal act, but can cause a feeling of injustice in society, which will discourage other persons from wanting involved in crimes, to make a deal with the state, without receiving leniency in return.

The implementation of measures of criminal procedural coercion (this is especially characteristic of persons who are first brought to criminal liability) lead to positive psychological changes in the personality aimed at the formation of lawful behavior due to fear of punishment and the procedure of legal restrictions established by criminal procedural legislation ...

The application of the provisions of criminal legislation aimed at eliminating criminal consequences (Articles 75, 76, 761, 762 of the Criminal Code of the Russian Federation) [1], in conjunction with legal restrictions established by criminal procedure legislation, contribute to the achievement of the preventive tasks of criminal legislation and say on the complex nature of measures of criminal law impact.

An analysis of the criminal legislation and other branches of law shows that the measures of criminal law are not limited to measures of a coercive nature, including measures by which criminal liability is implemented. As already noted, measures aimed at creating favorable conditions conducive to lawful behavior, which are mostly not coercive measures, should be referred to measures of criminal law.

The implementation of measures of criminal law, through which criminal liability is not implemented, can be carried out not only by the court, but also by the investigator with the consent of the head of the investigative body or the investigator with the consent of the prosecutor. These powers of the subjects of criminal procedural relations on the part of the prosecution are provided for by the provisions of Art. 25 of the Code of Criminal Procedure of the Russian Fed- 
eration, giving them the right to terminate criminal proceedings in connection with the reconciliation of the parties [2].

Compulsory measures of a medical nature, imposed for a committed criminal (socially dangerous) act, have a somewhat different legal nature. As previously noted by the author, these measures, on the one hand, act as a different measure of a criminal-legal nature, being one of the varieties of the implementation of criminal liability, assigned to persons who have committed a crime and suffering from mental disorders that do not exclude sanity, and in relation to persons suffering from pedophilia (paragraphs "c" and "d" part 1 of Art. 97 of the Criminal Code of the Russian Federation), on the other hand, the measures under consideration are assigned to persons who have committed a socially dangerous act in a state of insanity and to persons who become such after the commission of a crime (paragraphs "a" and "b" part of Art. 97 of the Criminal Code of the Russian Federation) $[1 ; 7 ; 8]$.

Along with achieving the goal aimed at preventing new socially dangerous acts in Art. 98 of the Criminal Code of the Russian Federation, the purpose of compulsory measures of a medical nature is to cure or improve the mental state of such persons, which, in turn, is also aimed at achieving the preventive tasks of criminal legislation (Art. 2 of the Criminal Code of the Russian Federation) [1]. Despite the fact that the goal of curing or improving the mental state of a person who has committed a socially dangerous act is highlighted in Art. 98 of the Criminal Code of the Russian Federation separately [1], it is also aimed at achieving the preventive tasks of criminal legislation.

The above analysis of criminal legislation and various approaches that take place in the criminal law literature (including the proposals of the author of this publication), measures of a criminal law nature should be divided into: 1) punishment, which is the main form of implementation of criminal liability; 2) other measures of a criminal-legal nature, which are an alternative form of implementation of criminal liability and, in comparison with punishment, have a lower intensity, entailing a smaller restriction of the rights and freedoms of persons who have committed criminal acts; 3) measures of a criminal-legal nature, by means of which criminal liability is not implemented.

The differentiation of measures of criminal law proposed above is largely conceptual in nature and was reflected only in the theory of criminal law, since the legislator erroneously referred to compulsory measures of a medical nature, assigned to persons, to other measures of a criminal law nature, committed a socially dangerous act in a state of insanity. It is due to the fact that compulsory medical measures imposed on the insane, by their legal nature, do not relate to alternative forms of implementation of criminal liability. These conclusions are confirmed by the provisions of Part 1 of Art. 21 of the Criminal Code of the Russian Federation, which states that persons who have committed socially dangerous acts are not subject to criminal liability [1].

The erroneous decisions of the legislator also include the legal regulation of section VI of the Criminal Code of the Russian Federation "Other measures of a criminal-legal nature", where he limited himself to including only compulsory medical measures, confiscation of property and a court fine. At the same time, the provisions of Art. 3, part 1 of Art. 6, part 2 of Art. 7 of the Criminal 
Code of the Russian Federation [1] and a number of other provisions of the criminal law indicate a wide variety of alternative forms of implementation of criminal liability. In particular, they include a conditional sentence (Art. 73 of the Criminal Code of the Russian Federation), a deferral according to the rules of Art. 82 of the Criminal Code of the Russian Federation, compulsory measures of educational influence, as well as other forms of implementation of criminal liability provided for by criminal legislation. Previously, the problem of regulating measures of criminal law was raised by the author in other publications [9, p. 12].

At the present time, it is obvious that the introduction of regulation of measures of criminal-legal influence in accordance with its legal nature is doubtful, since it can cause confusion in the law-enforcement practice and cause much more harm. For this reason, the regulation of measures of criminal law seems to be possible in the course of the development and adoption of the new Criminal Code of the Russian Federation, the need for which is long overdue [15.]

As a result of the study, the author proposes to give the following definition of measures of criminal law influence, indicating that it is a measure of state coercion, imposed by a court or other law enforcement body of the state in relation to a person who has committed a crime or socially dangerous act by an insane person, expressed in compulsory restriction or deprivation of his rights and freedoms, as well as the enforcement of measures and means aimed at preventing criminal (socially dangerous) acts.

So, the proposed definition reflects the legal nature of measures of criminal law impact, testifies to its complex nature, which should not be limited to criminal law and legal relations close to them, and the need for the legislator to develop measures aimed at preventing criminal activity ...

\section{Bibliographic list}

1. "The Criminal Code of the Russian Federation" dated 13.06.1996 No. 63-FZ (revised from 01.07.2021) // www.consultant.ru

2. "The Criminal Procedure Code of the Russian Federation" dated 12/18/2001 No. 174-FZ (as amended on 07/01/2021, as amended on 09/23/2021) // www. consultant.ru

3. Resolution of the Plenum of the Supreme Court of the Russian Federation of December 22, 2015 No. 58 "On the practice of imposing criminal punishment by the courts of the Russian Federation" // Bulletin of the Supreme Court of the Russian Federation. 2016. No. 2.

4. Bavsun M.V. Criminal law impact: ideology, goals and means and implementation // Diss. doc... jurid. sciences. Omsk, 2013. 396 p.

5. Veklenko S.V. On increasing the effectiveness of criminal law // Counteracting crime: criminal law, criminological and criminal executive aspects: materials of the III Russian Congress of Criminal Law (May 29 - May 30, 2008). Moscow, 2008. $736 \mathrm{p}$.

6. Veliev S.A. The general concept and meaning of criminal liability // "Black holes" in Russian legislation. Legal journal. 2004. No. 1. P. 94-101.

7. Gareev M.F. Alternatives in Criminal Law: Selected Aspects. // Legal thought. 2019. No. 6. P. 82-95. 
8. Gareev M.F. Some issues of the regulation of compulsory medical measures as another measure of a criminal-legal nature. // Modern criminal policy: search for an optimal model. Materials of the VII Russian Congress of Criminal Law (May 31 June 1, 2012) / Resp. ed. V.S. Komissarov. Moscow: Prospect, 2012. P. 37-39.

9. Gareev M.F. The goals of other measures of a criminal-legal nature and the means of achieving them in Russian criminal law: diss. cand. ... jurid. sciences. Kazan, 2005. $198 \mathrm{p}$.

10. Duyunov V.K. Criminal law impact: theory and practice. Moscow, 2003. 520 p.

11. Eleonsky V.A. Criminal punishment and education of the positive responsibility of the individual. Ryazan, 1979. 83 p.

12. Ozhegov S.I. and Shvedova N.Yu. Dictionary. //The Russian Academy of Sciences. Institute of the Russian language named after V.V. Vinogradov. 4th ed., Supplemented. Mosow: LLC "ITI Technology", 2006. P. 92.

13. Lopashenko N.A. The basics of criminal law impact: criminal law, criminal law, criminal law policy. St. Petersburg, 2004. 339 p.

14. Shooting in Kazan is overgrown with persons involved - Accidents - Kommersant. [Electronic resource] // Access mode: https://www.kommersant.ru/ doc/4889901 (date of appeal - August 30, 2021).

15. Modern criminal policy: search for an optimal model. Materials of the VII Russian Congress of Criminal Law (May 31 - June 1, 2012). / Resp. ed. V.S. Komissarov. Moscow: Prospect, 2012. 664 p.

16. Criminal law of Russia. A common part. Ed. F.R. Sundurova. Kazan: Kazan University Publishing House, 2003. 648 p.

17. Chronology of the execution: was it possible to prevent the tragedy in Kazan. [Electronic resource] // Access mode: https: ren.tv/criminal/832875 (date of appeal August 30, 2021).

18. Chuchaev A.I., Firsova A.P. Criminal law impact: concept, object, mechanism, classification: monograph. Moscow: Prospect, 2010. 320 p.

For citation: Gareev M.F. Criminal law impact: concept and legal nature: article // Legal thought. 2021. No. 4 (124). P. 146-153.

DOI: 10.47905 / MATGIP.2021.124.4.011

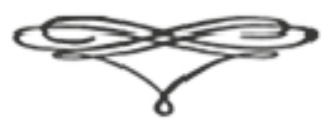


удк 343

ББK 67.0

DOI: $10.47905 /$ MATGIP.2021.124.4.012

\title{
УГОАОвно-Правовое вОЗАЕЙСТВне Н УГОАОВНАЯ ОТВЕТСТВЕНHОСТЬ
}

M.Ф. Гареєв ${ }^{*}$

\begin{abstract}
Аннотация. В данной статье рассматривается проблема дифференциации мер уголовно-правового воздействия. Предлагается разграничить меры уголовноправового воздействия на меры, связанные с реализацией уголовной ответственности, включая наказание и иные меры уголовно-правового характера, а также меры уголовно-правового характера, посредством которых она не реализуется. Раскрывается сущность и определение уголовной ответственности, ее место в системе мер уголовно-правового воздействия. Так как уголовная ответственность включает в себя наказание и иные меры уголовно-правового характера, то с учетом законодательно закрепленных норм и институтов уголовного законодательства и различных доктринальных подходов предмагается авторский вариант опредемения угомовной ответственности.

Предлагается авторский вариант содержания ч. 2 ст. 2 УК РФ, где дополняются иные меры уголовно-правового воздействия, посредством которых не реализуется уголовная ответственность.

Ключевые слова: уголовное законодательство; законодательная регламентация; меры уголовно-правового воздействия; задачи уголовного законодательства; уголовная ответственность; наказание; иные меры уголовно-правового характера; меры уголовно-правового характера, посредством которых не реализуется уголовная ответственность.
\end{abstract}

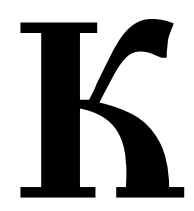

фундаментальным категориям уголовного права относится угомовная ответственность, от уяснения понятия и сущности которой зависит законодательная и правоприменительная практика. В юридической митературе содержатся размичные подходы к понятию и сущности уголовной ответственности [15, с. 23].

Отдельные ученые обращаются к философским аспектам уголовной ответственности [18, с. 79]. Среди специалистов в обцасти уголовного права, особенно это характерно дия советского периода развития уголовноправовой науки, имело место ограничение уголовной ответственности только рамками наказания [12, с. 25-26; 22, с. 9].

В предыдущих публикациях нами отмечалось, что уголовная ответственность реализуется посредством наказания и иных мер уголовноправового характера. Последние меры выступают альтернативой наказанию, и их перечень явцяется более обширным, чем предусмотрено в разде-

* Гареев Maрат Фаизович, доцент кафедры уголовного права и процесса Юридического института (Санкт-Петербург), кандидат юридических наук, доцент. E-mail: gareeff.marat2013@yandex.ru 
ме VI УК РФ под одноименным названием «Иные меры уголовно-правового характера" [10].

Положения ряда норм Общей части УК РФ показывают, что наказание и иные меры уголовно-правового характера расположены в одном категориальном ряду, посредством которых реализуется уголовная ответственность.

Типичным примером сказанному служат положения ч. 1 ст. 6 УК РФ, в которой указано, что наказание и иные меры уголовно-правового характера, применяемые к мицу, совершившему преступление, должны быть справедиивыми, то есть соответствовать характеру и степени обществен-

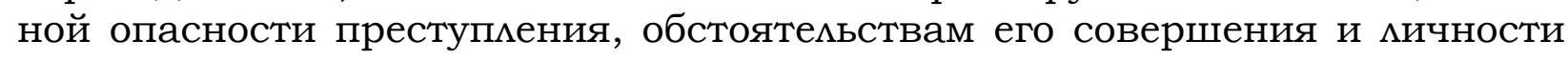
виновного.

О необходимости соблюдения принципа гуманизма при реализации уголовной ответственности предписывают положения ч. 2 ст. 7 УК РФ: «Наказание и иные меры уголовно-правового характера, применяемые к мицу, совершившему преступление, не могут своей целью иметь причинение физических страданий или унижение человеческого достоинства».

Ряд институтов и норм уголовного закона указывает, что уголовная ответственность, представленная в УК РФ, в виде наказания и иных мер уголовно-правового характера, не является единственной разновидностью мер уголовно-правового воздействия.

Встречаются и иные точки зрения, которые исключают уголовную ответственность, как правовую категорию, а акцентируют внимание на наказании, как одном из средств уголовно-правового воздействия, существующего наряду с другими эмементами [5, с. 45].

Категория "уголовная ответственность" пронизывает разцичные ее институты и нормы: преступление и состав преступления, его объективные и субъективные признаки, неоконченное преступление, соучастие в преступлении, множественность преступлений, сущность, содержание и цели наказания, общие начала и иные требования, предъявляемые к назначению наказания, сущность, социальное предназначение и механизм реализации иных мер уголовно-правового характера, вопросы дифференциации уголовной ответственности и индивидуализации наказания, построение

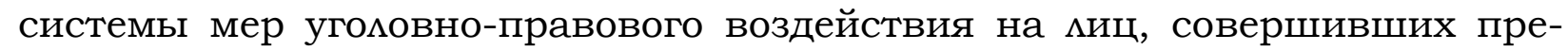
ступления [8, с. 12].

Уголовная ответственность, как уголовно-правовая категория, сразу же упоминается в ч. 1 ст. 1 УК РФ. В ней зафиксировано, что новые законы, предусматривающие уголовную ответственность, подлежат включению в настоящий Кодекс. Рассматриваемая категория упоминается также в ст. 5 УК РФ, в которой речь идет о принципе вины.

$\mathrm{K}$ основополагающим принципам уголовного права можно отнести также содержание ст. 8 УК РФ, закрепившую основанием уголовной ответственности совершение деяния, содержащего все признаки состава преступления, предусмотренного настоящим Кодексом.

В научном сообществе большинство ученых акцентируют внимание на определении ретроспективной или негативной уголовной ответственности. Так, А.В. Наумов под ней понимает все меры уголовно-правового воз- 
действия, применяемые к мицу, совершившему преступление [16, с. 246]. По мнению И.Я. Козаченко, уголовная ответственность представляется как

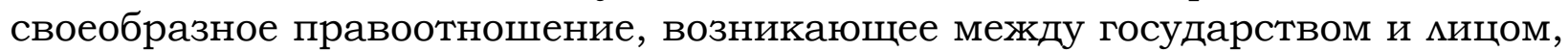
совершившим преступление, по поводу его мичных имущественных и неимущественных прав, которые в связи с содеянным вынужденно подвергаются социально-правовой корректировке [19, с. 113, 119].

"Уголовная ответственность, - пишет Р.Р. Галиакбаров, - это вытекающее из требований уголовного закона осуждение мица с применением предусмотренных законом мер уголовно-правового воздействия" [7, с. 30]. Несмотря на маконичность последнего определения, в нем отражен сущно-

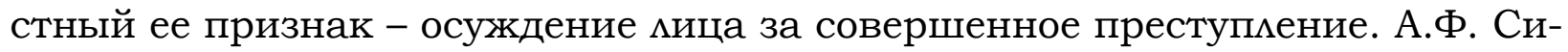
зый определяет уголовную ответственность следующим образом: "Это установленная уголовным законом обязанность мица отбывать наказание или иные меры уголовно-правового характера за совершение таким мицом общественно опасного деяния. А сущность уголовной ответственности заклю-

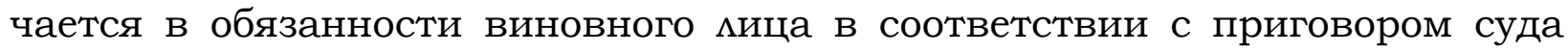
в установленном законом порядке ответить за совершенное преступцение» [17, с. 102].

Как считает С.Г. Келина, уголовная ответственность выступает реакцией государства на совершение преступления, выражающаяся в опредемении преступного поведения мица государством и принудитемьном огра-

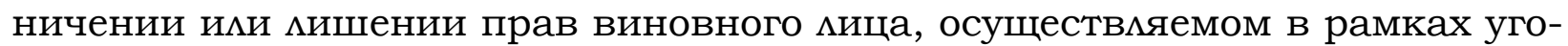
мовного правоотношения [14, с. 479].

По мнению $\Lambda . \Lambda$. Кругликова и А.В. Василевского, уголовная ответственность - это претерпевание мицом, совершившим преступление, мер

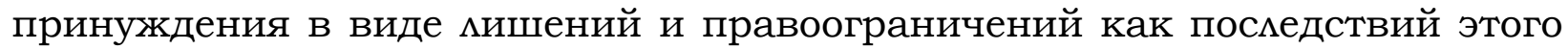

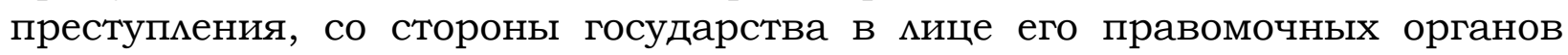
в рамках штрафной санкции нормы уголовного закона [13, с. 33]. Такое определение ответственности, как полагают вышеуказанные авторы, охватывают ее объективные и субъективные аспекты, объясняет необходимость появцения и употребления данного термина, соответствует законодательным конструкциям [13, с. 34].

Рассматривая уголовную ответственность как разновидность меры угомовно-правового воздействия, последнее уголовно-правовое явцение предмагают изложить в качестве мегального определения со следующей формулировкой: "Мера уголовно-правового воздействия (характера) есть мера государственного принуждения, назначаемая судом мицу, совершившему общественно опасное деяние, и заключающееся в предусмотренных настоящим Кодексом мишении или ограничении прав и свободы этого Аица" [23, с. 55].

Основным предназначением мер уголовно-правового воздействия, вкцючая меры, связанные с реализацией уголовной ответственности, является охрана наиболее ценных общественных отношений, закрепленных в Особенной части УК РФ и предупреждение преступных деяний (ст. 2 УК РФ) [15].

Преобладающее число авторов связывают уголовную ответственность в уголовном праве с обязанностью виновного мица в совершении преступмения отвечать за содеянное, с наступлением дмя него негативных последствий [20, с. 74]. 
Сторонники ретроспективного подхода к уголовной ответственности момент ее возникновения связывают с фактом совершения преступления конкретным мицом [21, с. 49].

Обоснованность данного подхода объясняется предусмотренными в уголовно-процессуальном законодатель-стве мер уголовно-процессуального принуждения, регламентированные в гл. 13 УПК РФ мер пресечения (подписка о невыезде, мичное поручительство, набцюдения командования воинской части и др.).

О реализации уголовной ответственности задоцго до вынесения обвинительного приговора и признания мица виновным в совершении преступления свидетельствуют положения ч.ч. 3 и 4 ст. 72 УК РФ, а также разъяснения Постановцения Пценума Верховного Суда РФ от 29 ноября 2016 г. № 55 «О судебном приговоре", предусматривающие зачет в срок наказания нахождение подсудимого под стражей, а в случае назначения наказания, не связанного с мишением свободы, и освобождение от дальнейшего отбывания наказания [2].

В пользу вышеупомянутых доводов указывают положения ст. ст. 108, 109 УПК РФ, разъяснения Постановления Пленума Верховного Суда РФ от 19 декабря 2013 г. № 41 «О практике применения судами законодательства о мерах пресечения в виде заключения под стражу, домашнего ареста, замога и запрета опредеменных действий", предусматривающий основание и порядок избрания меры пресечения в виде заключения под стражу и домашнего ареста, а также исчисление их сроков [3].

По этому поводу наиболее точно мнение А.В. Наумова: «... когда вина обвиняемого будет подтверждена обвинительным приговором, применяемые к нему меры процессуального принуждения превращаются в составную часть уголовной ответственности" [16, с. 246-247].

Несмотря на наличие непосредственной связи уголовной ответственности с уголовно-процессуальным законодательством, выраженное в установлении факта порицания, осуждения преступления и мица его совершившего, на основании обвинительного приговора суда, осуществляемого в рамках уголовного правоотношения, данные обстоятельства многими исследователями оставляются без внимания.

С учетом всех особенностей категории уголовной ответственности наиболее предпочтительным представляется ее определение, сформулированное С.Г. Келиной, охватывающее наиболее ключевые моменты с учетом авторских дополнений в данное определение. Одними из таких дополнений доцжны выступить положения о социально-правовом назначении уголовной ответственности, а также указание о том, что ее материально-правовой базой явцяется уголовный закон [11, с. 68].

С учетом анализа уголовного законодательства и исследований в обмасти уголовного права можно отметить, что угоцовная ответственность занимает ключевое место в системе мер уголовно-правового воздействия. Поэтому, при фрормулировании определения уголовной ответственности возникает необходимость указать на ее связь с целями уголовно-правового воздействия. В свою очередь, последние позволяют правоприменителю выбрать тот или иной вид уголовной ответственности и даже в определенных случаях допускают возможность освобождения от нее. 
Как ранее отмечалось автором, сущность уголовной ответственность

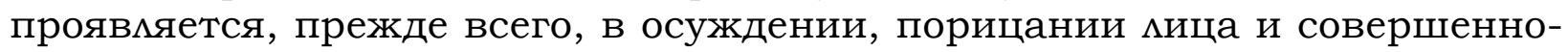
го им преступления от имени государства, выраженное в обвинительном

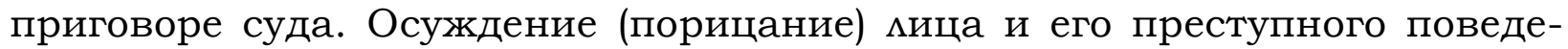

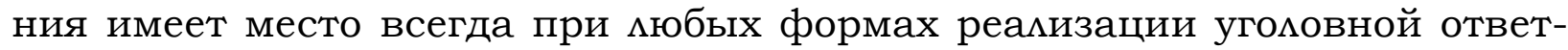
ственности, в том числе и при привлечении к ней с освобождением от наказания.

Таким образом, уголовная ответственность - это предусмотренная уголовным законом и выраженная в обвинительном приговоре суда мера государственного принуждения, выражающаяся в осуждении (порицании)

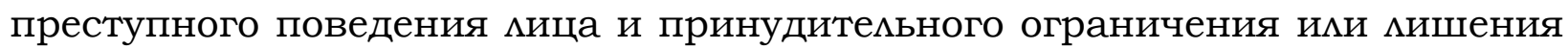
его прав и свобод, осуществляемая в рамках уголовного правоотношения в соответствии с целями уголовно-правового воздействия и задачами угомовного законодатемьства [8, с. 7].

Как показывает анализ преобладающих норм и институтов уголовного права, уголовная ответственность, занимая значительное место в системе мер уголовно-правового воздействия, не явцяется единственной. Угомовное законодательство содержит в системе мер уголовного правового воздействия различные виды мер уголовно-правового характера, не относящиеся к наказанию и иным мерам уголовно-правового характера, посредством которых реализуется уголовная ответственность. В частности, к мерам уголовно-правового характера можно отнести различные виды освобождения от уголовной ответственности.

Выделение мер уголовно-правового характера в системе мер уголовно-правового воздействия явцяется условным и обусловлено необходимостью дифференциации последних. Также оно вызвано необходимостью разграничения мер угомовно-правового воздействия, посредством которых реализуется уголовная ответственность и на меры, не относящихся к таковым.

Следуя могике нормотворческой регламентации всех мер уголовноправового воздействия в уголовном законодательстве, можно выдемить три основных их раздема.

Меры уголовно-правового воздействия, посредством которых реализуется уголовная ответственность. К ним, как уже было отмечено выше, относятся наказание и альтернативные формы реализации уголовной ответственности, обозначенные законодателем в уголовном законе как иные меры уголовно-правового характера. В уголовном законодательстве к альтернативньи формам реализаиии уголовной ответственности можно отнести не только те меры, которые законодательно закреплены в разделе VI УК РФ (принудительные меры медицинского характера, конфискация имущества, судебный штраф) но и иные меры уголовно-правового характера, получившие законодательную регламентацию в иных главах Общей части уголовного закона. В частности, к таковым относится условное осуждение (ст. ст. 73, 74 УК РФ), условно-досрочное освобождение (ст. 79 УК РФ), отсрочка наказания по правилам ст. 82 УК РФ, принудительные меры воспитательного воздействия (ст. 92 УК), разцичные виды освобождения от отбывания наказания. 
К третьему разделу относятся меры уголовно-правового характера, которые не выступают формами реализаиии уголовной ответственности (например, гмава 11 УК РФ (ст. 75, 76¹, 76², 78 УК РФ)).

Отдельно заслуживают внимания разграничения альтернативных видов уголовной ответственности, не отнесенные законодателем к наказанию, от мер уголовно-правового воздействия, посредством которых она не реализуется. При обращении к различным видам освобождения от уголовной ответственности, предусмотренная главой 11 УК РФ (деятельное раскаяние, примирение с потерпевшим и др.), цогику законодателя можно объяснить достижением задач уголовного законодательства, направленных на предупреждение преступлений (ст. 2 УК РФ), когда сам факт привлечения $\mathrm{K}$ уголовной ответственности и применения уголовно-процессуальных мер принуждения (в частности, избрание меры пресечения в виде подписки о невыезде и надмежащем поведение) может отбить у мица, впервые совершившего преступное деяние, всякое желание продолжить преступную деятельность.

Определенное недоумение вызывает регламентация принудитемьных мер медицинского воздействия, размещенные только в одной главе 15 УК РФ. Хотя, если следовать могике законодателя, который регламентирует разцичные меры уголовно-правового воздействия, то возникает необходимость их дифференциации на иные меры уголовно-правового характера и меры уголовно-правового характера, применяемые, в том числе, в отношении миц, признанных судом невменяемыми. Ранее автором проблема регламентации принудительных мер медицинского характера поднималась в предыдущих публикациях, так как налицо меры, обусловленные необходимостью исполнения ряда международных обязательств, принятых Российской Федерации, в борьбе с терроризмом, коррупцией, наркоторговлей и др. [9, с. 37-39; 10].

Подобного рода просчеты законодателя приводят отдемьных специамистов к ошибочным выводам о том, что принудительные меры медицинского характера, применяемые в отношении невменяемых, подчеркивают их не уголовно-правовую природу, и они назначаются "вовсе не за совершение преступлений" [6, с. 135].

Положения общей части уголовного законодательства, включая его задачи и принципы, свидетельствуют о принудительном характере мер уголовно-правового воздействия (раздем I и глава 15 УК РФ). Данные утверждения в полной мере распространяются и на принудительные меры медицинского характера.

Доводы о не уголовно-правовом характере принудительных мер медицинского характера опровергаются положениями ст. 4 Закона РФ от 02.07.1992 г. № 3185-1 «О психиатрической помощи и гарантиях прав граждан при ее оказании" [1], согласно которой оказание психиатрической помощи носит сугубо добровоцьный характер. Исключения установлены только в ст. 29 данного Закона РФ, которые включают:

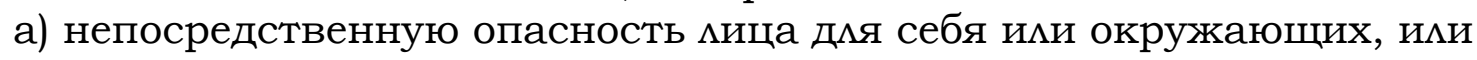

б) его беспомощность, то есть неспособность самостоятельно удовцетворять основные жизненные потребности, ими 
в) возможность причинения существенного вреда его здоровью вследствие ухудшения психического состояния, если мицо будет оставмено без психиатрической помощи [1].

Данный перечень является закрытым и расширительному толкованию не подмежит.

Об уголовно-правовом характере принудительных мер медицинского характера, даже включая те, которые применяются в отношении невменяемых, свидетельствуют положения ст. 97 УК РФ и п. 3 Постановления Пиенума Верховного Суда РФ от 7 апреля 2011 г. № 6 «О практике применения судами принудительных мер медицинского характера". Из них следует, что принудительные меры медицинского характера применяются в связи с совершенным общественно опасным деянием, предусмотренным Особенной частью УК РФ [4]. Это как раз подчеркивает уголовно-правовой характер рассматриваемых мер. Тем более, следует принять во внимание, что предупредительные цели принудительных мер медицинского характера, установленные в ст. 98 УК РФ согласуются с превентивными задачами уголовного законодательства, предусмотренными ст. 2 УК РФ.

Вышеприведенные положения главы 15 УК РФ, особенно это касается п. «а" ч. 1 ст. 97 УК РФ, наглядно показывают, что меры уголовно-правового воздействия не ограничиваются только мерами, связанными с реализацией уголовной ответственностью (наказанием и иными мерами уголовноправового характера). Соответственно, уголовным законодательством к мерам уголовно-правового воздействия также отнесены меры уголовноправового характера, посредством которых не реализуется уголовная ответственность.

На основании проведенного анализа вышеперечисленных норм и институтов уголовного законодательства, а также с учетом разцичных доктринальных подходов к фундаментальным институтам уголовного права, в целях предоставления ориентиров в законотворческой и правоприменительной практике предлагается изложить ч. 2 ст. 2 УК РФ в следующей редакции: "Для осуществления этих задач настоящий Кодекс устанав ивает основание и принципы уголовной ответственности, определяет, какие опасные для мичности, общества или государства деяния признаются преступлениями, и устанавцивает виды наказаний и иные меры уголовноправового характера за совершение, а также другие виды уголовноправового воздействия, не связанные с реализацией уголовной ответственности.

\section{Библиографический список}

1. Закон Российской Федерации от 02.07.1992 г. № 3185-1 «О психиатрической помощи и гарантиях прав граждан при ее оказании" //Ведомости Съезда народных депутатов Российской Федерации и Верховного Совета РФ от 20 августа 1992 г. № 33. Ст. 1913.

2. Постановление Пиенума Верховного Суда РФ от 29 ноября 2016 г. № 55 "О судебном приговоре» //Бюмметень Верховного Суда РФ. 2017. № 1.

3. Постановцение Пценума Верховного Суда РФ от 19 декабря 2013 г. № 41 "О практике применения судами законодательства о мерах пресечения в виде за- 
ключения под стражу, домашнего ареста, залога и запрета опредеменных действий" / /Бюмлетень Верховного Суда РФ. 2014. № 2.

4. Постановление Пценума Верховного Суда РФ от 7 апреля 2011 г. № 6 "О практике применения судами принудительных мер медицинского характера" // Бюмлетень Верховного Суда РФ. 2011. № 7.

5. Бавсун М.В. Уголовно-правовое воздействие: идеология, цели и средства и реализации: дисс. док... юрид. наук, - Омск, 2013. - 396 с.

6. Благов. Наказание и иные меры уголовно-правового характера: мекции. М.: Юрлитиформ, 2011. - 240 с.

7. Галиакбаров Р.Р. Уголовное право. Общая часть. - Краснодар, 1999. - 280 с.

8. Гареев М.Ф. Цели иных мер уголовно-правового характера и средства их достижения по российскому уголовному праву: автореф. дисс. канд. ... юрид. наук. - Казань, 2005. -23 с.

9. Гареев М.Ф. Некоторые вопросы регламентации принудительных мер медицинского характера как иной меры уголовно-правового характера. // Современная уголовная политика: поиск оптимальной модели. Материалы VII Российского конгресса уголовного права (31 мая - 1 июня 2012 г.) /Отв. ред. В.С. Комиссаров. - М.: Проспект, 2012. - С. 37-39.

10. Гареев М.Ф. Альтернативы в уголовном праве: отдельные аспекты // Юридическая мысль. 2019. № 6. С. 82-95.

11. Келина С.Г. Освобождение от уголовной ответственности как правовое последствие совершения преступцения //Уголовное право: новые идеи. - М., 1994. - 102 с.

12. Кропачев В.И., Прохоров В.С. Механизм уголовно-правового регулирования: уголовная ответственность. - СПб., 2000. - 60 с.

13. Кругликов $\Lambda . \Lambda .$, Васимевский А.В. Дифференциация ответственности в уголовном праве. - СПб., 2003. - 300 с.

14. Курс российского уголовного права. Общая часть. Под ред. В.Н. Кудрявцева и А.В. Наумова. - М.: СПАРК, 2001. - 767 с.

15. Марцев А.И. Уголовная ответственность и общее предупреждение преступлений. - Омск, 1973. - 96 с. $560 \mathrm{c.}$

16. Наумов А.В. Уголовное право. Общая часть. Курс мекций. - М.: БЕК, 1996. $176 \mathrm{c}$.

17. Сизый А.Ф. Уголовное право. Общая часть. - Чебоксары, 2001. - С. 102. -

18. Смирнов В.Г. Уголовная ответственность и уголовное наказание // Правоведение. 1963. № 4. - С. 78-89.

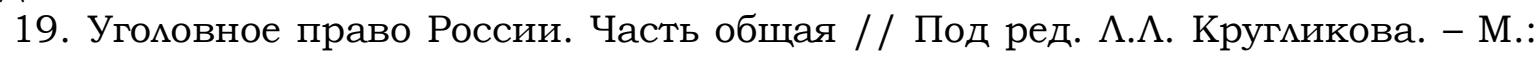
БEK, 2005. - 592 c.

20. Уголовное право. Общая часть. Учебник для вузов. - М.: Норма, 2001. 576 c.

21. Уголовное право России. Части Общая и Особенная: Учебник. //Под ред. А.И. Рарога. - М.: Проспект, 2004. - 624 с.

22. Хомич В.М. Формы реализации уголовной ответственности в условиях правового государства //Борьба с преступлениями в условиях формирования правового государства. Рига, 1990. - С. 7-9.

23. Чучаев А.И., Фирсова А.П. Уголовно-правовое воздействие: понятие, объект, механизм, классификация: монография - М.: Проспект, 2010. - 320 с.

Дия цитирования: Гареев М.Ф. УГоловно-правовое воздействие и уголовная ответственность: статья // Юридическая мысль. 2021. № 4 (124). С. 154-161.

DOI: $10.47905 /$ MATGIP.2021.124.4.012 


\section{Criminal law impact and criminal liability}

Marat F. Gareev *

Annotation. This article examines the problem of differentiation of measures of criminal law impact. It is proposed to distinguish between measures of criminal law impact on measures related to the implementation of criminal liability, including punishment and other measures of a criminal law nature, as well as measures of a criminal law nature, through which it is not implemented. The essence and definition of criminal responsibility, its place in the system of measures of criminal-legal influence are revealed. Since criminal liability includes punishment and other measures of a criminal-legal nature, then, taking into account the legislatively enshrined norms and institutions of criminal legislation and various doctrinal approaches, the author's version of the definition of criminal liability is proposed.

The author's version of the content of Part 2 of Art. 2 of the Criminal Code of the Russian Federation, where other measures of criminal law are added, through which criminal liability is not implemented.

Key words: criminal legislation; legislative regulation; measures of criminal law; tasks of criminal legislation; criminal liability; punishment; other measures of a criminal law nature; measures of a criminal-legal nature, by means of which criminal liability is not implemented.

The fundamental categories of criminal law include criminal liability, on the understanding of the concept and essence of which legislative and law enforcement practice depends. The legal literature contains various approaches to the concept and essence of criminal liability [15, p. 23].

Some scholars turn to the philosophical aspects of criminal responsibility [18, p. 79]. Among specialists in the field of criminal law, this is especially characteristic of the Soviet period of development of criminal law science, there was a limitation of criminal liability only to the framework of punishment [12, p. 25-26; 22, p. 9].

In previous publications, we noted that criminal liability is implemented through punishment and other measures of a criminal law nature. The latter measures act as an alternative to punishment and their list is more extensive than provided for in Section VI of the Criminal Code of the Russian Federation under the same name "Other measures of a criminal law nature" [10].

The provisions of a number of norms of the General Part of the Criminal Code of the Russian Federation show that punishment and other measures of a criminal-legal nature are located in the same category, through which criminal liability is implemented.

A typical example of this is the provisions of Part 1 of Art. 6 of the Criminal Code of the Russian Federation, which states that punishment and other measures of a criminal-legal nature applied to a person who committed a crime must be fair, that is, correspond to the nature and degree of social

* Gareev Marat Faizovich, associate professor of the Law Institute (St. Petersburg), candidate of legal sciences. E-mail: gareeff.marat2013@yandex.ru 
danger of the crime, the circumstances of its commission and the identity of the perpetrator.

The need to comply with the principle of humanism in the implementation of criminal liability is prescribed by the provisions of Part 2 of Art. 7 of the Criminal Code of the Russian Federation: "Punishment and other measures of a criminal-legal nature applied to a person who committed a crime cannot be aimed at causing physical suffering or humiliation of human dignity."

A number of institutions and norms of the criminal law indicate that criminal liability presented in the Criminal Code of the Russian Federation, in the form of punishment and other measures of a criminal law nature, is not the only type of criminal law measures.

There are also other points of view that exclude criminal liability as a legal category, and focus on punishment as one of the means of criminal law impact, which exists along with other elements [5, p. 45].

The category of "criminal responsibility" permeates its various institutions and norms: crime and corpus delicti, its objective and subjective signs, unfinished crime, complicity in a crime, a plurality of crimes, the nature, content and purposes of punishment, general principles and other requirements for imposition of punishment, the essence, social purpose and mechanism for the implementation of other measures of a criminal-legal nature, issues of differentiation of criminal responsibility and individualization of punishment, construction of a system of measures of criminal-legal influence on persons who have committed crimes [8, p. 12].

Criminal liability, as a criminal law category, is immediately mentioned in Part 1 of Art. 1 of the Criminal Code of the Russian Federation. It states that new laws providing for criminal liability are to be included in this Code. The category in question is also mentioned in Art. 5 of the Criminal Code of the Russian Federation, which deals with the principle of guilt.

The fundamental principles of criminal law can also include the content of Art. 8 of the Criminal Code of the Russian Federation, which established the commission of an act containing all the signs of the composition of a crime provided for by this Code as the basis of criminal liability.

In the scientific community, most scientists focus on the definition of retrospective or negative criminal liability. So, A.V. Naumov understands it as all the measures of criminal-legal action applied to the person who committed the crime [16, p. 246]. According to I. Ya. Kozachenko, criminal liability is presented as a kind of legal relationship that arises between the state and the person who committed the crime regarding his personal property and nonproperty rights, which in connection with the deed are forced to undergo social and legal adjustment [19, p. 113, 119].

"Criminal liability", writes R.R. Galiakberov, is the conviction of a person following from the requirements of the criminal law with the use of measures of criminal law stipulated by the law" [7, p. thirty]. Despite the brevity of the last definition, it reflects its essential feature - the conviction of a person for a crime. A.F. Sizy defines criminal liability as follows: "This is the obligation of a person, established by the criminal law, to serve a sentence or other measures of a criminal-legal nature for the commission of a so- 
cially dangerous act by such a person. And the essence of criminal responsibility lies in the responsibility of the guilty person in accordance with the court verdict in the manner prescribed by law to answer for the crime committed" [17, p. 102].

According to S.G. Kelin, criminal responsibility acts as a reaction of the state to the commission of a crime, expressed in the determination of the criminal behavior of a person by the state and compulsory restriction or deprivation of the rights of the guilty person, carried out within the framework of a criminal legal relationship [14, p. 479].

According to L.L. Kruglikova and A.V. Vasilevsky, criminal liability is the suffering of a person who committed a crime, coercive measures in the form of deprivation and legal restrictions as the consequences of this crime, by the state represented by its competent authorities within the framework of a penalty sanction of the norms of criminal law [13, p. 33]. Such a definition of responsibility, as the above authors believe, encompasses its objective and subjective aspects, explains the need for the appearance and use of this term, and corresponds to legislative structures [13, p. 34].

Considering criminal liability as a kind of a measure of criminal law influence, it is proposed to state the last criminal law phenomenon as a legal definition with the following wording: , and consisting in the deprivation or restriction of the rights and freedom of this person provided for by this Code" [23, p. 55].

The main purpose of criminal law measures, including measures related to the implementation of criminal liability, is the protection of the most valuable public relations enshrined in the Special Part of the Criminal Code of the Russian Federation and the prevention of criminal acts (Article 2 of the Criminal Code of the Russian Federation) [15].

The overwhelming number of authors associate criminal responsibility in criminal law with the obligation of the guilty person in committing a crime to be responsible for what he has done, with the onset of negative consequences for him [20, p. 74].

Supporters of a retrospective approach to criminal liability associate the moment of its occurrence with the fact of a crime committed by a specific person [21, p. 49].

The validity of this approach is explained by the measures of criminal procedural coercion provided for in the criminal procedural legislation, regulated in ch. 13 of the Code of Criminal Procedure of the Russian Federation of preventive measures (written undertaking not to leave the place, personal surety, observation of the command of the military unit, etc.).

The provisions of ch.ch. 3 and 4 Art. 72 of the Criminal Code of the Russian Federation, as well as clarifications of the Resolution of the Plenum of the Supreme Court of the Russian Federation of November 29, 2016 No. 55 "On a court verdict", providing for the offset of the defendant's being in custody in the term of punishment, and in the case of imposing a punishment not related to imprisonment, and release from further serving the sentence [2].

In favor of the above arguments, the provisions of Art. Art. 108, 109 of the Criminal Procedure Code of the Russian Federation, clarifications of the 
Resolution of the Plenum of the Supreme Court of the Russian Federation of December 19, 2013 No. 41 "On the practice of the courts' application of legislation on preventive measures in the form of detention, house arrest, bail and prohibition of certain actions", which provides for the basis and the procedure for choosing a preventive measure in the form of detention and house arrest, as well as the calculation of their terms [3].

In this regard, the most accurate opinion of A.V. Naumova: "... when the guilt of the accused is confirmed by a conviction, the measures of procedural coercion applied to him turn into an integral part of criminal liability" [16, $\mathrm{p}$. 246-247].

Despite the presence of a direct connection between criminal liability and criminal procedural legislation, expressed in the establishment of the fact of censure, conviction of the crime and the person who committed it, on the basis of the conviction of the court, carried out within the framework of the criminal legal relationship, these circumstances are given by many researchers neglected.

Taking into account all the features of the category of criminal responsibility, its definition, formulated by S.G. Kelina, covering the most key points, taking into account the author's additions to this definition. One of these additions should be provisions on the social and legal designation of criminal liability, as well as an indication that its material and legal basis is the criminal law [11, p. 68].

Taking into account the analysis of criminal legislation and research in the field of criminal law, it can be noted that criminal liability occupies a key place in the system of measures of criminal law. Therefore, when formulating the definition of criminal liability, it becomes necessary to indicate its connection with the goals of criminal law. In turn, the latter allow the law enforcement officer to choose one or another type of criminal liability and even in certain cases allow the possibility of exemption from it.

As previously noted by the author, the essence of criminal responsibility is manifested, first of all, in the conviction, censure of the person and the crime committed by him on behalf of the state, expressed in the conviction of the court. Condemnation (censure) of a person and his criminal behavior always takes place in any form of implementation of criminal liability, including when brought to it with release from punishment.

Thus, criminal liability is a measure of state coercion provided for by the criminal law and expressed in the court's conviction, expressed in the conviction (censure) of the criminal behavior of a person and the compulsory restriction or deprivation of his rights and freedoms, carried out within the framework of a criminal legal relationship in accordance with the goals of criminal law legal impact and the tasks of criminal legislation [8, p. 7].

As the analysis of the prevailing norms and institutions of criminal law shows, criminal liability, occupying a significant place in the system of measures of criminal law, is not the only one. Criminal legislation contains in the system of measures of criminal legal impact various types of measures of a criminal-legal nature, not related to punishment and other measures of a criminal-legal nature, by means of which criminal liability is implemented. In 
particular, various types of exemption from criminal liability can be attributed to measures of a criminal-legal nature.

The allocation of measures of a criminal-legal nature in the system of measures of criminal-legal impact is conditional and is due to the need to differentiate the latter. It is also caused by the need to distinguish between the measures of criminal law by means of which criminal liability is implemented and measures that are not related to such.

Following the logic of the rule-making regulation of all measures of criminal-legal influence in the criminal legislation, there are three main sections.

Measures of criminal law by means of which criminal responsibility is implemented. These, as already noted above, include punishment and alternative forms of implementation of criminal liability, designated by the legislator in the criminal law as other measures of a criminal-legal nature. In criminal law, alternative forms of implementing criminal liability include not only those measures that are legislatively enshrined in Section VI of the Criminal Code of the Russian Federation (compulsory medical measures, confiscation of property, a court fine) but also other measures of a criminal law that have received legislative regulation in other chapters of the General part of the criminal law. In particular, these include conditional conviction (Articles 73, 74 of the Criminal Code of the Russian Federation), parole (Article 79 of the Criminal Code of the Russian Federation), deferral of punishment according to the rules of Art. 82 of the Criminal Code of the Russian Federation, compulsory measures of educational influence (Art. 92 of the Criminal Code), various types of release from serving a sentence.

The third section includes measures of a criminal-legal nature that do not act as forms of implementation of criminal liability (for example, Chapter 11 of the Criminal Code of the Russian Federation (Articles 75, 761, 762, 78 of the Criminal Code of the Russian Federation)).

Separately, noteworthy is the distinction between alternative types of criminal liability, not attributed by the legislator to punishment, from the measures of criminal law by means of which it is not implemented. When referring to various types of exemption from criminal liability, provided for in Chapter 11 of the Criminal Code of the Russian Federation (active repentance, reconciliation with the victim, etc.), the logic of the legislator can be explained by the achievement of the tasks of criminal legislation aimed at preventing crimes (Art.2 Of the Criminal Code of the Russian Federation), when the very fact of bringing to criminal responsibility and the application of criminal procedural measures of coercion (in particular, the choice of a preventive measure in the form of a recognizance not to leave the place and proper behavior) can discourage a person who has committed a criminal act for the first time, any desire to continue the criminal activity.

Certain bewilderment is caused by the regulation of compulsory measures of medical influence, placed in only one chapter 15 of the Criminal Code of the Russian Federation. Although, if you follow the logic of the legislator, which regulates various measures of criminal law, then there is a need to differentiate them into other measures of a criminal law nature and measures of a criminal law nature, which are used, inter alia, in relation to persons recog- 
nized by the court as insane ... Earlier, the author raised the problem of the regulation of compulsory medical measures in previous publications, since there are measures due to the need to fulfill a number of international obligations taken by the Russian Federation in the fight against terrorism, corruption, drug trafficking, etc. [9, p. 37-39; 10].

Such miscalculations of the legislator lead individual specialists to erroneous conclusions that compulsory medical measures applied to the insane, emphasize their non-criminal-legal nature, and they are appointed "not at all for committing crimes" [6, p. 135].

The provisions of the general part of criminal legislation, including its objectives and principles, testify to the coercive nature of criminal law measures (Section I and Chapter 15 of the Criminal Code of the Russian Federation). These statements fully apply to compulsory medical measures.

Arguments about the non-criminal nature of compulsory measures of a medical nature are refuted by the provisions of Art. 4 of the Law of the Russian Federation of 02.07.1992, No. 3185-1 "On psychiatric care and guarantees of the rights of citizens in its provision" [1], according to which the provision of psychiatric care is purely voluntary. Exceptions are established only in Art. 29 of this Law of the Russian Federation, which include:

a) an immediate danger of a person to himself or others, or

b) his helplessness, that is, the inability to independently satisfy the basic needs of life, or

c) the possibility of causing significant harm to his health due to the deterioration of his mental state, if the person is left without psychiatric care [1].

This list is closed and not subject to broad interpretation.

The provisions of Art. 97 of the Criminal Code of the Russian Federation and clause 3 of the Resolution of the Plenum of the Supreme Court of the Russian Federation dated April 7, 2011 No. 6 "On the practice of using compulsory medical measures by the courts". It follows from them that compulsory measures of a medical nature are applied in connection with a committed socially dangerous act provided for by the Special Part of the Criminal Code of the Russian Federation [4]. This just underlines the criminal law nature of the measures under consideration. Moreover, it should be taken into account that the preventive goals of compulsory measures of a medical nature, established in Art. 98 of the Criminal Code of the Russian Federation are consistent with the preventive tasks of the criminal legislation provided for in Art. 2 of the Criminal Code of the Russian Federation.

The above provisions of Chapter 15 of the Criminal Code of the Russian Federation, especially paragraph "a" of Part 1 of Art. 97 of the Criminal Code of the Russian Federation clearly show that the measures of criminal law are not limited only to measures related to the implementation of criminal liability (punishment and other measures of a criminal law nature). Accordingly, the criminal legislation also includes measures of a criminal-legal nature, through which criminal liability is not implemented, as measures of criminal law.

Based on the analysis of the above norms and institutions of criminal law, as well as taking into account various doctrinal approaches to the fundamental institutions of criminal law, in order to provide guidelines in lawmaking 
and law enforcement practice, it is proposed to outline Part 2 of Art. 2 of the Criminal Code of the Russian Federation in the following revision: "For the implementation of these tasks, this Code establishes the basis and principles of criminal liability, determines which acts dangerous for the individual, society or the state are recognized as crimes, and establishes the types of punishments and other measures of a criminal-legal nature for committing, as well as other types of criminal law impact not related to the implementation of criminal liability.

\section{Bibliographic list}

1. Law of the Russian Federation of 02.07.1992, No. 3185-1 "On psychiatric care and guarantees of the rights of citizens in its provision" // Bulletin of the Congress of People's Deputies of the Russian Federation and the Supreme Soviet of the Russian Federation of August 20, 1992, No. 33. Art. 1913.

2. Resolution of the Plenum of the Supreme Court of the Russian Federation of November 29, 2016 No. 55 "On the court verdict" // Bulletin of the Supreme Court of the Russian Federation. 2017. No. 1.

3. Resolution of the Plenum of the Supreme Court of the Russian Federation of December 19, 2013 No. 41 "On the practice of the courts' application of legislation on preventive measures in the form of detention, house arrest, bail and prohibition of certain actions" // Bulletin of the Supreme Court of the Russian Federation. 2014. No. 2.

4. Resolution of the Plenum of the Supreme Court of the Russian Federation dated April 7, 2011 No. 6 "On the practice of using compulsory medical measures by the courts" // Bulletin of the Supreme Court of the Russian Federation. 2011. No. 7.

5. Bavsun M.V. Criminal law impact: ideology, goals and means and implementation. // Diss. doc... jurid. Sciences. Omsk, 2013. 396 p.

6. Blagov. Punishment and other measures of a criminal law nature: lectures. Moscow: Jurlitiform, 2011. 240 p.

7. Galiakbarov R.R. Criminal law. A common part. Krasnodar, 1999. 280 p.

8. Gareev M.F. The goals of other measures of a criminal-legal nature and the means of achieving them in Russian criminal law: author. diss. cand. ... jurid. sciences. Kazan, 2005. 23 p.

9. Gareev M.F. Some issues of the regulation of compulsory medical measures as another measure of a criminal-legal nature. // Modern criminal policy: search for an optimal model. Materials of the VII Russian Congress of Criminal Law (May 31 June 1, 2012) / Ed. ed. V.S. Komissarov. Moscow: Prospect, 2012. P. 37-39.

10. Gareev M.F. Alternatives in criminal law: some aspects // Legal thought. 2019. No. 6. P. 82-95.

11. Kelina S.G. Exemption from criminal liability as a legal consequence of the commission of a crime // Criminal law: new ideas. Moscow, 1994. 102 p.

12. Kropachev V.I., Prokhorov V.S. The mechanism of criminal law regulation: criminal liability. Saint Petersburg, 2000. 60 p.

13. Kruglikov L.L., Vasilevsky A.V. Differentiation of responsibility in criminal law. Saint Petersburg, 2003. 300 p.

14. The course of Russian criminal law. A common part. Ed. V.N. Kud-Ryavtseva and A.V. Naumova. Moscow: SPARK, 2001. 767 p.

15. Martsev A.I. Criminal liability and general crime prevention. Omsk, 1973. 96 p.

16. Naumov A.V. Criminal law. A common part. Lecture course. Moscow: BEK, 1996. 560 p.

17. Sizy A.F. Criminal law. A common part. Cheboksary, 2001. 176 p. 
18. Smirnov V.G. Criminal responsibility and criminal punishment // Jurisprudence. 1963. No. 4. P. 78-89.

19. Criminal law of Russia. General part // Ed. L.L. Kruglikova. Moscow: BEK, 2005. $592 \mathrm{p}$

20. Criminal law. A common part. Textbook for universities. Moscow: Norma, 2001. 576 p.

21. Criminal law of Russia. Parts General and Special: Textbook. // Ed. A.I. Rarog. Moscow: Prospect, 2004. 624 p.

22. Khomich V.M. Forms of implementation of criminal responsibility in a legal state // Combating crime in the formation of a legal state. Riga, 1990. P. 7-9.

23. Chuchaev A.I., Firsova A.P. Criminal law impact: concept, object, mechanism, classification: monograph. Moscow: Prospect, 2010. 320 p.

For citation: Gareev M.F. Criminal law impact and criminal liability: article // Legal thought. 2021. No. 4 (124). P. 162-169.

DOI: 10.47905 / MATGIP.2021.124.4.012

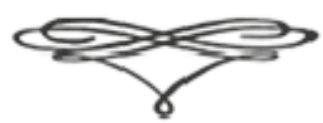




\title{
В ПОМОЩЬ ПРЕПОДАВАТЕАЮ
}

\section{Удк 343.98}

DOI: $10.47905 /$ MATGIP.2021.124.4.013

\author{
Хекцня: \\ - средстваX овеспечення Безопасностн \\ н ПрОТнвоАЕйствня ТЕррорнзму
}

\section{Ф.Н. Бастрыкнн*}

\begin{abstract}
Аннотация. В данной мекции содержатся предможения по повышению эффективности организации работы следственных органов Следственного комитета Российской Федерации на современном этапе по системной разработке мер по противодействию экстремизму и терроризму. Автор особое внимание уделяет нормативно-правовому обеспечению работы следственных органов Следственного комитета в условиях возросших коммуникационных возможностей интернетресурсов.

Автор считает, что назрел вопрос о кодификации миграционного законодательства, где ясно следует прописать все формы миграции, объединить нормы, связанные с регистрацией иностранцев, с выдачей квот на занятие трудовой деятельностью, четко определить порядок учета мигрантов, их дактилоскопирования и другие виды контроля.

Ключевые слова: эффективность, уголовное законодательство, уголовнопроцессуальное право, Следственный комитет, прокуратура, миграция, интернетресурсы, информация.
\end{abstract}

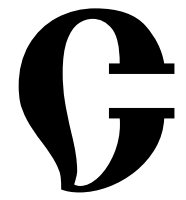

егодня молодое поколение, которое отчасти попало под вцияние идеологического вакуума 1990-х годов, нередко становится объектом змонамеренной идеологической обработки, толкающей ее на путь экстремизма, национальной и религиозной нетерпимости.

Молодежь пытаются разцожить новые религиозные движения (такие, как "Свидетели Иеговы", сайентологи и другие), чуждые нашей духовной культуре.

Вместе с тем в патриотическом воспитании молодежи, в её духовном и нравственном развитии огромную роль играет Русская Православная Церковь, Всемирный Русский Народный Собор, вся многогранная деятельность которых направлена на единение и сплоченность народов в нашем многонациональном государстве, на укрепление мира и справедливости в обществе, на поддержку авторитета семьи.

* Бастрыкин Александр Иванович, председатель Следственного комитета Российской Федерации, доктор юридических наук, профессор, Заскуженный юрист Российской Федерации. E-mail: lawinst-spb@mail.ru 
Особо следует подчеркнуть важную работу Русской Православной Церкви, направленную на объективное освещение богатейшей истории нашей страны, в борьбе за целостность нашего народа, на духовную и нрав-

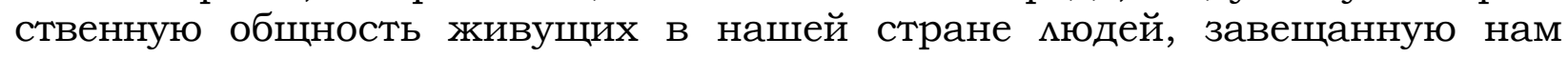
славными предками.

В единстве, заложенном еще крестителем Руси князем Владимиром, заключено огромное преимущество России. Прекратив междоусобицы, князь Владимир тем самым показал стремление нашего народа к высоким идеалам добра, правды и справедливости. Федор Михайлович Достоевский назвал все это "всечеловечностью".

Огромная сила нашей страны заключается в том, что на протяжении одиннадцати с половиной столетий российское государство развивалось путем объединения земель на основе уважения прав и традиций всех насемявших их народов. Это предопределило создание такой обширной и уникальной державы, как Российская империя, а впоследствии - РСФСР, Российская Федерация.

На торжествах в День народного единства 4 ноября 2017 г. Президент России Владимир Владимирович Путин напомниц, что единство и патриотизм были дмя народа самой надежной опорой и в годы тяжелых испытаний, и при решении масштабных задач развития: "Бережное отношение к Родине, забота о ней, верность искренней дружбе и неприятие какогомибо давцения извне это несущие конструкции российской государственности, наш генетический и кумьтурный код. Традиции взаимного доверия и согласия народов России наполняют единство нации особой внутренней симой".

На надежную защиту этих ценностей направлено функционирование всего государственного механизма. Его составной частью является Следственный комитет Российской Федерации, решающий чрезвычайно важную задачу по расследованию наиболее опасных для общества преступлений экстремистского характера и террористической направленности.

В нашей многонациональной и многоконфессиональной стране в обязательном порядке следует системно подходить к разработке мер по противодействию экстремизму и терроризму. В этой связи подчеркну, что с момента своего образования Следственный комитет РФ неоднократно поднимал вопрос об усицении уголовной ответственности за экстремизм и терроризм.

В итоге в Уголовный кодекс Российской Федерации были внесены существенные поправки, ужесточающие уголовную ответственность за экстремистские и террористические преступления, уточнено понятие «финансирование терроризма", введена уголовная ответственность за реабилитацию нацизма (статья 354.1 УК РФ “Реабилитация нацизма»).

Кроме того, Федеральным законом от 6 июля 2016 г. № 375-Ф3 «О внесении изменений в Уголовный кодекс Российской Федерации и Уголовнопроцессуальный кодекс Российской Федерации в части установления дополнительных мер противодействия терроризму и обеспечения общественной безопасности" Уголовный кодекс дополнен статьей 205.6 «Несообщение о преступлении", устанавцивающей ответственность за несообщение в ор- 
ганы власти, уполномоченные рассматривать сообщения о преступлении, о мице (Аицах), которое по достоверно известным сведениям готовит, совершает или совершило хотя бы одно из преступлений террористической направленности.

Помимо этого, Уголовный кодекс РФ дополнен новой ст. 361 «Акт международного терроризма", выделяющей в отдельный состав совершение вне пределов территории Российской Федерации взрыва, поджога или иных действий, подвергающих опасности жизнь, здоровье, свободу или неприкосновенность граждан России в целях нарушения мирного сосуществования государств и народов, мибо направленных против интересов нашей страны. Именно по этой статье Гцавным управцением по расследованию особо важных дец Сцедственного комитета РФ возбуждено уголовное демо по факту убийства 19 декабря 2016 г. Чрезвычайного и Полномочного Посла Российской Федерации в Турецкой Республике Андрея Карлова. В рамках уголовного дела в соответствии с нормами российского уголовнопроцессуального законодательств и международного права проводятся следственные действия, направленные на установление всех возможных

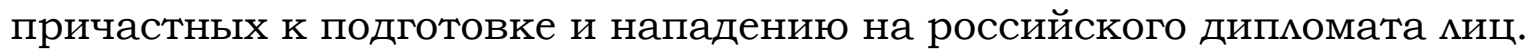

Рассматривая вопрос об информационном противодействии экстремизму, следует отметить, что в Российской Федерации принят закон о блокировке экстремистских сайтов (Федеральный закон от 28 декабря 2013 г. № 398-Ф3 "О внесении изменений в Федеральный закон "Об информации, информационных технологиях и о защите информации"»). В ноябре 2014 г. Президентом Российской Федерации утверждена Стратегия противодействия экстремизму в Российской Федерации.

Это позволяет Следственному комитету РФ совместно с другими государственными органами, прежде всего с Федеральной службой по надзору в сфрере связи, информационных технологий и массовых коммуникаций (Роскомнадзор), Генеральной прокуратурой и Министерством юстиции Российской Федерации оперативно реагировать на провокации экстремистов, использующих интернет-ресурсы для разжигания национальной и религиозной вражды, удалять информацию, содержащую призывы к массовым беспорядкам, осуществлению экстремистской деятельности, участию в массовых (публичных) мероприятиях, проводимых с нарушением установленного порядка.

Вместе с тем ситуация в области противодействия экстремизму и терроризму в России все еще остается сложной.

В связи с этим одна из сфер пристального внимания Следственного комитета Российской Федерации - активное пресечение экстремистских проявлений, рост которых в 2016 году составиц 11 \% (1 161 преступление). Выявмены 707 миц, совершивших преступления экстремистской направменности. Следователями Следственного комитета РФ в суд направлены 249 уголовных дем о таких преступлениях (приведены статистические данные за первое полугодие 2016 г.).

Помимо этого, Следственным комитетом РФ возбуждены 137 уголовных дем о преступлениях террористического характера, в суд направлены 56 таких дем (приведены статистические данные за 1 полугодие 2016.). 
Основные экстремистские и террористические угрозы, как и ранее, связаны с деятельностью бандгрупп на Северном Кавказе снижается активность распространения идеологии терроризма и экстремизма через сеть Интернет. Продолжается подбор и вербовка российских граждан дмя участия в международных террористических организациях.

Прогнозируемое обострение ситуации с началом участия Воздушнокосмических сил России в боевых действиях против террористов в Сирийской Арабской Республике подтверждается исходящими угрозами от ИГИА и других международных террористических организаций. В Российскую Федерацию пытаются проникать боевики из "горячих точек" (Сирии, Аивии, Йемена, Ирака), проводятся теракты в отношении российских граждан за рубежом.

Сложная оперативная обстановка требует координации усиций всех противодействующих экстремизму и терроризму структур, ужесточения контроля миграционных потоков, пресечения вербовочной деятельности со стороны международных террористических организаций, миквидации ресурсного и финансового обеспечения бандгрупп.

В целом такая координация осуществляется в соответствии с Указом Президента России от 15 февраля 2006 г. № 116 "О мерах по противодействию терроризму" Национальным антитеррористическим комитетом, в состав которого включен Председатель Следственного комитета Российской Федерации (Указ Президента Российской Федерации от 26 июня 2013 г. № 579).

Кроме того, в ГАавном следственном управлении Следственного комитета по Северо-Кавказскому федеральному округу несколько мет успешно действует межведомственная оперативная группа, а в каждом субъекте Российской Федерации этого округа работают постоянно действующие межведомственные координационно-аналитические следственно-оперативные группы. Их основная задача - раскрытие и расследование убийств, а также преступлений экстремистской направленности и террористического характера.

Достаточно сказать, что благодаря слаженным действиям таких групп были изобличены чмены бандподполья, совершившие диверсию на Баксанской гидроэлектростанции в Кабардино-Балкарской Республике.

$* * *$

В целях повышения качества и результатов по раскрытию и расследованию преступлений экстремистской и террористической направленности Следственным комитетом РФ издано распоряжение о совершенствовании работы по организации и расследованию таких преступлений.

Дия эффективного информационного обмена между государственными органами в борьбе с терроризмом Следственным комитетом РФ в сентябре 2015 г. подписано согмашение о взаимодействии с ФСБ России в рамках единого банка данных "Антитеррор".

Эти организационные меры позволили оперативно пресечь деятельность нескоцьких десятков преступных группировок, совершавших особо опасные преступления по мотивам национальной, расовой и религиозной 


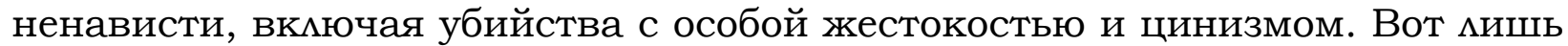
несколько характерных примеров.

Так, по результатам нашего расследования к длительным срокам мишения свободы осуждены:

несколько участников преступного сообщества, возглавцяемого Асланом Гагиевым, совершивших в 2004-2014 годах ряд убийств на территории Республики Северная Осетия - Алания и других субъектах Российской Федерации;

А^и Тазиев - один из приспешников Шамиля Басаева и организатор банды, на счету которой 78 убийств, в том числе сотрудников правоохранительных органов и военнослужащих в Северо-Кавказском федеральном округе.

Кроме того, следователями Главного следственного управления по Северо-Кавказскому федеральному округу совместно с сотрудниками ФСБ России изобличены шесть участников банды так называемого Хасавюртовского сектора, совершившие теракт около здания МВД России в г. Пятигорске в 2013 году. Приговором суда все они осуждены к длительным срокам мишения свободы.

Изоляция от общества этих и других особо опасных преступников в значительной мере позволила нанести ощутимый урон бандподполью.

Вынесены суровые приговоры (вплоть до пожизненного мишения свободы) организаторам и участникам экстремистского сообщества "Боевая организация русских националистов" (Горячеву, Исаеву, Баклагину), на счету которого десятки особо тяжких преступлений, в том числе убийства судьи Мосгорсуда Эдуарда Чувашова, адвоката Станислава Маркелова и журналистки Анастаии Бабуровой (за которое уже ранее осуждены Тихонов и Хасис).

Кроме того, к диительному сроку мишения свободы осужден Галиев, организовавший из числа молодых мусульман вооруженное преступное формирование с условным наименованием "Джамаат" и совершивший ряд террористических актов в Приволжском федеральном округе.

Приговором Верховного Суда Республики Татарстан к диительным срокам мишения свободы осуждены пять членов экстремистского сообщества "Ат-Такфир Валь-Хиджра", которые готовили террористический акт путем подрыва жемезнодорожных путей.

Таких примеров множество. Они свидетельствуют о высоком профессионализме и четком взаимодействии следователей с оперативными подраздемениями МВД и ФСБ России.

После исторического воссоединения Крыма с Россией проводится активная работа по предупреждению экстремизма и терроризма в Крыму. Создана межведомственная рабочая группа по координации деятемьности правоохранительных органов в сфере противодействия проявлениям экстремистской и террористической деятельности. Образована также постоянно действующая следственно-оперативная группа по раскрытию умышменных убийств. 
Все эти организационные меры и нацеленность на конечный результат позволили значительно активизировать работу по раскрытию и расследованию указанных преступлений, совершенных в том числе с применением огнестрельного оружия.

K примеру, по результатам расследования Гцавного следственного управления Следственного комитета по Республике Крым в г. Симферополе вынесен приговор Костенко - активному участнику массовых беспорядков в феврале 2014 года в г. Киеве, незаконно хранившему по месту жительства огнестрельное оружие, причинившему телесные повреждения сотруднику крымского спецподразделения "Беркут» (виновному назначено наказа-

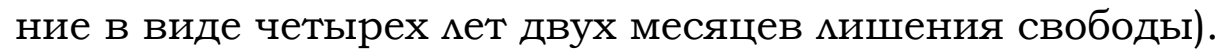

Вынесен также приговор Ааптеву - одному из руководителей банды "Казиновская", признанному виновным в бандитизме, совершении убийств с применением огнестрельного оружия и вымогательстве в период с 1994 по 2005 год в гг. Керчи, Феодосии Симферополе (виновному назначено наказание в виде 15 мет мишения свободы). Как вы знаете, в августе и ноябре 2016 года в Крыму обезврежены две диверсионные группы из числа радикалов и сотрудников Минобороны Украины, которые планировали атаки на жизненно важные объекты.

В 2015 году окончено расследование уголовного дела о наемничестве в отношении гражданина России - Разумова, который в 2014 году на территории Украины прошел боевую подготовку в рядах запрещенной в нашей стране экстремистской организации "Правый сектор". После возвращения в Россию он вербовал миц в ряды указанной экстремистской организации и размещал в социальной сети "ВКонтакте" экстремистскую информацию. За совершение указанных преступлений Разумову назначено наказание в виде 7 мет мишения свободы.

Сотрудниками управления по расследованию преступлений, связанных с применением запрещенных средств и методов ведения войны, ГСУ СК России совместно с ФСБ и МВД России проведен комплекс следственнооперативных мероприятий, в ходе которых получены данные, свидетельствующие о причастности ряда граждан России к деятельности экстремистской организации "Правый сектор", запрещенной решением Верховного Суда РФ на территории Российской Федерации.

На основании этих данных возбуждены уголовные дела в отношении пятерых граждан России: Игоря Чудинова, Геннадия Хамраева, Георгия Стоцкого, Романа Стригункова и А^ександра Валова. В их действиях усматриваются признаки преступлений, предусмотренных ч. 1 и 2 ст. 282.2 УК РФ (руководство деятельностью экстремистской организации и участие в ней).

Несколько слов об использовании экстремистами коммуникационных возможностей интернет-ресурсов.

Буквально недавно вынесен приговор в отношении Сюзева за пубмичную демонстрацию в социальной сети “ВКонтакте» текстовых и аудиовизуальных материалов экстремистской направленности, а также одоб- 
ряющих деятельность частей войск фашистской Германии «СС» в период Второй мировой войны.

Всего в 2016 г. правоохранительными органами выявцены свыше 300 миц, которые совершили экстремистские преступления с использованием интернет-ресурсов. Поэтому в целях блокировки экстремистских сайтов СК РФ активно взаимодействует с Роскомнадзором, куда направцяются полученные в ходе следствия материалы, подтверждающие распространение в Интернете противоправной информации.

В целях противодействия разцичного рода попыткам дестабилизировать обстановку в стране, необходима продуманная и последовательная концепция информационной политики. Причем с учетом особенностей информационной войны в связи с историческим воссоединением Крыма с Россией, возможно, следует разработать для Крыма и Севастополя особую концепцию информационной политики.

Кроме того, представляется целесообразным предусмотреть внесудебный (административный) порядок вкАючения информации в федеральный список экстремистских материалов, а также блокировки доменных имен сайтов, которые распространяют данную информацию. Если обладатели такой информации не считают ее экстремистской, у них есть возможность обжаловать соответствующие действия уполномоченных государственных органов в суд. Такой порядок даст возможность более оперативно реагировать на пропаганду экстремизма в Интернете.

В целях противодействия экстремизму и терроризму необходимо также принять меры к закреплению на законодательном уровне сроков хранения сведений о получателях оружия на заводах-изготовителях минимум 40-50 мет, обязательного клеймения оружия, позволяющего проследить его путь от изготовителя к потребителю, а также создания базы данных, обеспечивающей ведение подобного контроля и доступной дмя работы следователей по указанной категории уголовных дел.

Следственный комитет РФ выступает также за введение уголовной ответственности за выпуск и оборот денежных суррогатов (не предусмотренные законом средства платежа, в том числе электронном виде) так называемых криптовалют, наиболее известной из которых является биткоин. Это связано с тем, что транзакции в системе криптовалют производятся анонимно и без централизованного контроля. Анонимность пцатежей мотивирует к использованию виртуальной валюты для совершения преступлений, в том числе таких, как торговля наркотиками, оружием, фринансирование терроризма, уклонение от уплаты налогов.

Кроме того, по данным Генеральной прокуратуры Российской Федерации, оплата незаконно поставляемых так называемому Исламскому государству нефти и газа, а также вербовка новых членов этой террористической организацией осуществлялись с помощью виртуальных валют.

Следует отметить, что запрет на выпуск денежных суррогатов уже установлен в Федеральном законе от 10 июля 2002 г. № 86-ФЗ "О Центральном банке Российской Федерации (Банке России)". Между тем ответственность за нарушение данного запрета до сих пор отсутствует, хотя в Министерстве финансов России подготовлен проект федерального зако- 
на, предусматривающего введение уголовной ответственности за выпуск и оборот денежных суррогатов.

Кроме того, Следственным комитетом РФ поддерживается предложение ФСБ России о создании на международной арене общей базы данных иностранных террористов-боевиков и разработке дополнительных способов установцения их местонахождения, что позволит поставить дополнительный барьер дмя перемещения террористов в нашу страну.

Чувствительной темой, вызывающей большую обеспокоенность общества и требующей адекватных мер реагирования со стороны правоохранительных органов, является сращивание террористических и криминальных группировок, расширяющее могистические, материальные и технологические возможности экстремистов и террористов.

Острота криминогенной обстановки (особенно на фоне преступности мигрантов в странах Европейского Союза) диктует необходимость усиления комплексных профилактических мер по противодействию незаконной миграции. Они должны быть направлены, прежде всего, на поддержание достаточного уровня социального и экономического обеспечения мигрантов-иностранцев, работающих в нашей стране. Необходима также четкая координация деятецьности органов власти в части социально-культурной адаптации и интеграции мигрантов.

Следует также отметить, что, несмотря на большое число нормативных актов, регламентирующих миграционные процессы, формирование структуры российского миграционного законодательства до настоящего времени не завершено. Если взять в целом миграционное законодательство, то в настоящее время вопросы миграции в общей сложности регулируют свыше 700 нормативных актов. Это многопцановая и довоцьно запутанная нормативная база.

Поэтому назрел вопрос о кодификации миграционного законодательства, где ясно следует прописать все формы миграции, а также объединить нормы, связанные с регистрацией иностранцев, с выдачей квот на занятие трудовой деятельностью, четко определить порядок учета мигрантов, их дактилоскопирования и другие виды контроля. Здесь же следует закрепить порядок взаимодействия всех правоохранительных органов по пресечению незаконной миграции, что позволит осуществлять более действенный и результативный миграционный контроль.

Представляется, что именно такие меры позволят достичь главной цели - не только оперативно пресекать правонарушения в сфере миграции, но и своевременно их предупреждать.

В качестве дополнительной меры необходимо совместно с законодателями еще раз внимательно проанализировать действующую нормативную правовую базу с целью ее корректировки в направлении ужесточения уголовной ответственности за участие в террористической деятельности.

Дмя цитирования: Бастрыкин А.И. О средствах обеспечения безопасности и противодействия терроризму: мекция // Юридическая мысль. - 2021. - № 4 (124). - С. 170-177.

DOI: $10.47905 /$ MATGIP.2021.124.4.013 


\section{Lecture: \\ "On the means of ensuring security and countering terrorism "}

\section{Alexander I. Bastrykin*}

Annotation. This lecture contains proposals for increasing the efficiency of organizing the work of the investigative bodies of the Investigative Committee of the Russian Federation at the present stage for the systematic development of measures to counter extremism and terrorism. The author pays special attention to the regulatory and legal support of the work of the investigative bodies of the Investigative Committee in the context of the increased communication capabilities of Internet resources.

The author believes that the issue of codification of migration legislation is ripe, where all forms of migration should be clearly prescribed, the norms related to the registration of foreigners, with the issuance of quotas for employment; clearly define the procedure for registering migrants, their fingerprinting and other types of control.

Key words: efficiency, criminal legislation, criminal procedure law, Investigative Committee, prosecutor's office, migration, Internet resources, information.

Today, the younger generation, which partly fell under the influence of the ideological vacuum of the 1990 s, often becomes the object of malicious indoctrination, pushing it onto the path of extremism and ethnic and religious intolerance.

Young people are trying to corrupt new religious movements (such as Jehovah's Witnesses, Scientologists and others) that are alien to our spiritual culture.

At the same time, in the patriotic education of young people, in their spiritual and moral development, the Russian Orthodox Church, the World Russian People's Council play a huge role, all multifaceted activities of which are aimed at the unity and cohesion of peoples in our multinational state, at strengthening peace and justice in society, at support for the authority of the family.

It should be especially emphasized the important work of the Russian Orthodox Church aimed at objective coverage of the richest history of our country, in the struggle for the integrity of our people, at the spiritual and moral community of people living in our country, bequeathed to us by glorious ancestors.

The unity laid down by the baptist of Russia, Prince Vladimir, is a huge advantage of Russia. Stopping civil strife, Prince Vladimir thereby showed the desire of our people to the lofty ideals of good, truth and justice. Fyodor Mikhailovich Dostoevsky called all this "all-humanity".

The tremendous strength of our country lies in the fact that for eleven and a half centuries the Russian state has developed through the unification of lands on the basis of respect for the rights and traditions of all peoples inhabiting them. This predetermined the creation of such a vast and unique power as the Russian Empire, and later - the RSFSR, the Russian Federation.

* Bastrykin Alexander Ivanovich, Chairman of the Investigative Committee of the Russian Federation, Doctor of Law, Professor, Honored Lawyer of the Russian Federation. E-mail: lawinst-spb@mail.ru 
At the celebrations on National Unity Day on November 4, 2017, Russian President Vladimir Vladimirovich Putin recalled that unity and patriotism were the most reliable support for the people both in the years of difficult trials and in solving large-scale development tasks: loyalty to sincere friendship and rejection of any outside pressure are the supporting structures of Russian statehood, our genetic and cultural code. The traditions of mutual trust and consent of the peoples of Russia fill the unity of the nation with a special inner strength".

The functioning of the entire state mechanism is aimed at reliable protection of these values. Its component part is the Investigative Committee of the Russian Federation, which solves the extremely important task of investigating the most dangerous crimes of an extremist and terrorist nature for society.

In our multinational and multi-confessional country, it is imperative to take a systematic approach to the development of measures to counter extremism and terrorism. In this regard, I would like to emphasize that since its inception, the Investigative Committee of the Russian Federation has repeatedly raised the issue of increasing criminal liability for extremism and terrorism.

As a result, significant amendments were made to the Criminal Code of the Russian Federation to toughen criminal liability for extremist and terrorist crimes, the concept of "financing terrorism" was clarified, and criminal liability for the rehabilitation of Nazism was introduced (Article 354.1 of the Criminal Code of the Russian Federation "Rehabilitation of Nazism").

In addition, Federal Law No. 375-FZ of July 6, 2016 "On Amendments to the Criminal Code of the Russian Federation and the Criminal Procedure Code of the Russian Federation in terms of establishing additional measures to counter terrorism and ensure public safety" about a crime", which establishes responsibility for failure to report to the authorities authorized to consider reports of a crime, about a person (persons) who, according to reliably known information, prepares, commits or has committed at least one of the terrorist crimes.

In addition, the Criminal Code of the Russian Federation has been supplemented with a new Art. 361 "Act of International Terrorism", which distinguishes the commission of an explosion, arson or other actions outside the territory of the Russian Federation, endangering the life, health, freedom or inviolability of Russian citizens in order to violate the peaceful coexistence of states and peoples, or directed against the interests of our country ... It is under this article that the Main Directorate for Investigation of Particularly Important Cases of the Investigative Committee of the Russian Federation initiated a criminal case into the murder of the Ambassador Extraordinary and Plenipotentiary of the Russian Federation to the Republic of Turkey Andrei Karlov on December 19, 2016. In the framework of the criminal case, in accordance with the norms of Russian criminal procedural legislation and international law, investigative actions are being carried out aimed at identifying all possible persons involved in the preparation and attack on the Russian diplomat.

Considering the issue of information counteraction to extremism, it should be noted that the Russian Federation adopted a law on blocking extremist websites (Federal Law No. 398-FZ of December 28, 2013 "On Amendments to the Federal Law "On Information, Information Technologies and Infor- 
mation Protection"»). In November 2014, the President of the Russian Federation approved the Strategy for Countering Extremism in the Russian Federation.

This allows the Investigative Committee of the Russian Federation, together with other state bodies, primarily with the Federal Service for Supervision in the Sphere of Communications, Information Technology and Mass Media (Roskomnadzor), the General Prosecutor's Office and the Ministry of Justice of the Russian Federation to promptly respond to provocations by extremists who use Internet resources to incite ethnic and religious hatred, delete information containing calls for mass riots, the implementation of extremist activities, participation in mass (public) events held in violation of the established order.

At the same time, the situation in the field of countering extremism and terrorism in Russia is still difficult.

In this regard, one of the areas of close attention of the Investigative Committee of the Russian Federation is the active suppression of extremist manifestations, the growth of which in 2016 was $11 \%$ (1,161 crimes). 707 persons have been identified who have committed extremist crimes. Investigators of the Investigative Committee of the Russian Federation sent 249 criminal cases on such crimes to court (statistics for the first half of 2016 are given).

In addition, the Investigative Committee of the Russian Federation initiated 137 criminal cases on terrorist crimes, 56 such cases were sent to court (statistical data for the first half of 2016 are given).

The main extremist and terrorist threats, as before, are associated with the activities of bandit groups in the North Caucasus, the activity of spreading the ideology of terrorism and extremism through the Internet is decreasing. The selection and recruitment of Russian citizens to participate in international terrorist organizations continues.

The predicted aggravation of the situation with the beginning of the participation of the Russian Aerospace Forces in hostilities against terrorists in the Syrian Arab Republic is confirmed by outgoing threats from ISIS and other international terrorist organizations. Militants from "hot spots" (Syria, Libya, Yemen, Iraq) are trying to infiltrate the Russian Federation, terrorist attacks are being carried out against Russian citizens abroad.

The complex operational situation requires coordination of efforts of all structures countering extremism and terrorism, tightening control of migration flows, suppressing recruitment activities by international terrorist organizations, and liquidating the resource and financial support of bandit groups.

In general, such coordination is carried out in accordance with the Decree of the President of Russia of February 15, 2006 No. 116 "On measures to counter terrorism" by the National Anti-Terrorism Committee, which includes the Chairman of the Investigative Committee of the Russian Federation (Decree of the President of the Russian Federation of June 26, 2013. No. 579).

In addition, an interdepartmental operational group has been successfully operating in the Main Investigation Department of the Investigative Committee for the North Caucasian Federal District for several years, and in each constituent entity of the Russian Federation of this district there are permanent interdepartmental coordination-analytical investigative-operational groups. Their main task is to solve and investigate murders, as well as crimes of an extremist and terrorist nature. 
Suffice it to say that thanks to the coordinated actions of such groups, members of the underground gangs who committed sabotage at the Baksan hydroelectric power station in the Kabardino-Balkarian Republic were exposed.

In order to improve the quality and results in the disclosure and investigation of crimes of an extremist and terrorist nature, the Investigative Committee of the Russian Federation issued an order to improve the work on the organization and investigation of such crimes.

For effective information exchange between government agencies in the fight against terrorism, the Investigative Committee of the Russian Federation in September 2015 signed an agreement on interaction with the FSB of Russia within the framework of a single anti-terror databank.

These organizational measures made it possible to promptly suppress the activities of several dozen criminal groups that committed especially dangerous crimes based on national, racial and religious hatred, including murders with particular cruelty and cynicism. Here are just a few typical examples.

So, according to the results of our investigation, the following were sentenced to long terms of imprisonment:

- several members of the criminal community headed by Aslan Gagiev, who committed a number of murders in 2004-2014 in the Republic of North Ossetia-Alania and other constituent entities of the Russian Federation;

- Ali Taziev is one of Shamil Basayev's henchmen and the organizer of the gang, which has 78 murders, including law enforcement officers and military personnel in the North Caucasian Federal District.

In addition, the investigators of the Main Investigation Department for the North Caucasus Federal District, together with the FSB of Russia, exposed six members of the gang of the so-called Khasavyurt sector, who committed a terrorist attack near the building of the Ministry of Internal Affairs of Russia in Pyatigorsk in 2013. By a court verdict, they were all sentenced to long terms of imprisonment.

Isolation from society of these and other especially dangerous criminals to a large extent allowed to inflicting tangible damage on the bandit underground.

Harsh sentences (up to life imprisonment) were passed to the organizers and participants of the extremist community "Fighting Organization of Russian Nationalists" (Goryachev, Isaev, Baklagin), who has been responsible for dozens of particularly grave crimes, including the murder of Moscow City Court judge Eduard Chuvashov, lawyer Stanislav Markelov journalist Anastaia Baburova (for which Tikhonov and Khasis were already convicted).

In addition, Galiev was sentenced to a long term of imprisonment, which organized an armed criminal group from among young Muslims with the code name "Jamaat" and committed a number of terrorist acts in the Volga Federal District.

The Supreme Court of the Republic of Tatarstan sentenced five members of the extremist community At-Takfir Wal-Hijra to long terms of imprisonment for preparing a terrorist act by blowing up railway tracks. 
There are many such examples. They testify to the high professionalism and clear interaction of the investigators with the operational units of the Ministry of Internal Affairs and the FSB of Russia.

After the historic reunification of Crimea with Russia, active work is being carried out to prevent extremism and terrorism in Crimea. An interdepartmental working group has been created to coordinate the activities of law enforcement agencies in the field of countering manifestations of extremist and terrorist activity. A permanent investigative-operational group has also been formed to solve premeditated murders.

All these organizational measures and focus on the final result have made it possible to significantly intensify the work on the disclosure and investigation of these crimes, including those committed with the use of firearms.

For example, according to the results of the investigation of the Main Investigation Department of the Investigative Committee for the Republic of Crimea in Simferopol, Kostenko was sentenced - an active participant in the mass riots in February 2014 in Kiev, who illegally stored firearms at his place of residence, who caused bodily harm to an employee of the Crimean special forces " Berkut "(the guilty person was sentenced to four years and two months in prison).

A verdict was also passed on Laptev, one of the leaders of the Kazinovskaya gang, who was found guilty of banditry, committing murders with the use of firearms and extortion in the period from 1994 to 2005 in the years. Kerch, Feodosia Simferopol (the guilty was sentenced to 15 years in prison). As you know, in August and November 2016, two sabotage groups from among the radicals and employees of the Ministry of Defense of Ukraine, who were planning attacks on vital facilities, were neutralized in Crimea.

In 2015, the investigation of a criminal case on mercenary activity against a Russian citizen, Razumov, was completed, who in 2014 underwent combat training on the territory of Ukraine in the ranks of the Right Sector extremist organization banned in our country. After returning to Russia, he recruited persons into the ranks of the said extremist organization and posted extremist information on the VKontakte social network. For the commission of these crimes, Razumov was sentenced to 7 years in prison.

Employees of the department for the investigation of crimes related to the use of prohibited means and methods of warfare, the Main Investigative Directorate of the Investigative Committee of Russia, together with the FSB and the Ministry of Internal Affairs of Russia, carried out a set of investigative and operational measures, during which data was obtained indicating the involvement of a number of Russian citizens in the activities of the extremist organization "Right sector ", prohibited by the decision of the Supreme Court of the Russian Federation on the territory of the Russian Federation.

Based on these data, criminal cases were initiated against five citizens of Russia: Igor Chudinov, Gennady Khamraev, Georgy Stotsky, Roman Strigunkov and Alexander Valov. In their actions, signs of crimes under Part 1 and 2 of Art. 282.2 of the Criminal Code of the Russian Federation (management of the activities of an extremist organization and participation in it). 
$* * *$

A few words about the use of communication capabilities of Internet resources by extremists.

Just recently, a verdict was passed against Syuzev for publicly displaying text and audio-visual materials of an extremist nature on the VKontakte social network, as well as approving the activities of SS units of Nazi Germany during the Second World War.

In total, in 2016, law enforcement agencies identified over 300 individuals who committed extremist crimes using Internet resources. Therefore, in order to block extremist sites, the Investigative Committee of the Russian Federation actively interacts with Roskomnadzor, where materials obtained during the investigation are sent, confirming the dissemination of illegal information on the Internet.

In order to counteract various attempts to destabilize the situation in the country, a well-thought-out and consistent concept of information policy is needed. Moreover, taking into account the peculiarities of the information war in connection with the historical reunification of Crimea with Russia, it may be necessary to develop a special concept of information policy for Crimea and Sevastopol.

In addition, it seems advisable to provide for an extrajudicial (administrative) procedure for including information in the federal list of extremist materials, as well as blocking the domain names of sites that disseminate this information. If the owners of such information do not consider it extremist, they have the opportunity to appeal against the relevant actions of the authorized state bodies in court. This procedure will make it possible to more quickly respond to the propaganda of extremism on the Internet.

In order to counter extremism and terrorism, it is also necessary to take measures to consolidate at the legislative level the storage time for information about recipients of weapons at manufacturing plants for at least 40-50 years, obligatory branding of weapons, which allows tracing its path from manufacturer to consumer, as well as creating a database, ensuring the conduct of such control and available for the work of investigators in this category of criminal cases.

The Investigative Committee of the Russian Federation also advocates the introduction of criminal liability for the issuance and circulation of monetary surrogates (non-statutory means of payment, including in electronic form) of the so-called cryptocurrencies, the most famous of which is bitcoin. This is due to the fact that transactions in the cryptocurrency system are carried out anonymously and without centralized control. Anonymity of payments motivates the use of virtual currency to commit crimes, including such as drug trafficking, weapons, terrorism financing, and tax evasion.

In addition, according to the General Prosecutor's Office of the Russian Federation, payments for oil and gas illegally supplied to the so-called Islamic State, as well as the recruitment of new members by this terrorist organization, were carried out using virtual currencies.

It should be noted that the ban on the issuance of monetary surrogates has already been established in the Federal Law of July 10, 2002 No. 86-FZ "On the Central Bank of the Russian Federation (Bank of Russia)". Meanwhile, 
there is still no liability for violation of this prohibition, although the Russian Ministry of Finance has prepared a draft federal law providing for the introduction of criminal liability for the issuance and circulation of money surrogates.

In addition, the Investigative Committee of the Russian Federation supports the proposal of the FSB of Russia to create in the international arena a common database of foreign terrorist-fighters and to develop additional methods for establishing their whereabouts, which will create an additional barrier to the movement of terrorists to our country.

A sensitive topic of great concern to society and requiring an adequate response from law enforcement agencies is the merging of terrorist and criminal groups, expanding the logistic, material and technological capabilities of extremists and terrorists.

The severity of the crime situation (especially against the background of the crime of migrants in the European Union) dictates the need to strengthen comprehensive preventive measures to counter illegal migration. They should be aimed, first of all, at maintaining an adequate level of social and economic security for foreign migrants working in our country. There is also a need for clear coordination of the activities of the authorities in terms of socio-cultural adaptation and integration of migrants.

It should also be noted that, despite the large number of regulations governing migration processes, the formation of the structure of Russian migration legislation has not yet been completed. If we take migration legislation as a whole, then at present migration issues are regulated in total by over 700 normative acts. This is a multifaceted and rather confusing regulatory framework.

Therefore, the issue of codification of migration legislation has matured, where all forms of migration should be clearly prescribed, as well as the norms related to the registration of foreigners, with the issuance of quotas for employment, clearly define the procedure for registering migrants, their fingerprinting and other types of control. Here it is necessary to consolidate the order of interaction of all law enforcement agencies to suppress illegal migration, which will allow for more efficient and effective migration control.

It seems that it is precisely such measures that will help achieve the main goal - not only to promptly suppress offenses in the field of migration, but also to prevent them in a timely manner.

As an additional measure, it is necessary, together with legislators, to carefully analyze the current regulatory legal framework once again with a view to adjusting it in the direction of toughening criminal liability for participation in terrorist activities.

For citation: Bastrykin A.I. On the means of ensuring security and countering terrorism: lecture // Legal thought. 2021. No. 4 (124). P. 178-184.

DOI: 10.47905 / MATGIP.2021.124.4.013

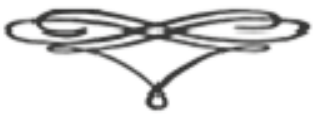




\title{
ПЕРСОНАМИИ
}

\author{
удк 340 \\ ББK 67.0 \\ DOI: 10.47905/MATGIP.2021.124.4.014
}

\section{Внктору Васнаьевнчу Бороднну нСПОАнНАОСЬ 65 АЕТ}

\section{G.đ. Комаров ${ }^{*}$}

Аннотация. Статья посвящена юбилею доктора юридических наук, профессора, академика МААН, заслуженного юриста Российской Федерации, чмена Ассоциации юристов России, полковника вн. службы (в отставке) - Виктора Васильевича Бородина.

КАючевые слова: Бородин В.В., юриспруденция, юридические науки, правовая культура.

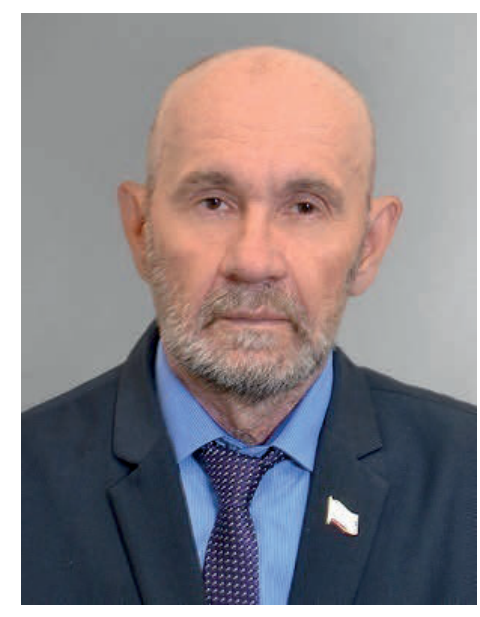

14 ноября 2021 года исполнилось 65 мет Заслуженному юристу Российской Федерации, чцену Ассоциации юристов России, чкену Межрегиональной ассоциации теоретиков государства и права, доктору юридических наук, профессору, академику МАAН, независимому эксперту Конституционного суда России, полковнику полиции (в отставке) Виктору Васильевичу Бородину. Он отмечает двойной юбимей -65 мет со дня рождения и 35 мет педагогической деятельности.

В.В. Бородин родицся в 1956 году в городе Аипецке. В 1980 году с отличием окончил Каунасскую среднюю специальную школу милиции МВД СССР. В 1980-1981 проходиц службу в домжности оперуполномоченного ОБХСС г. Аипецка. В 1981 г. поступил в Высшее политическое училище им. 60-летия ВАКСМ МВД СССР.

После окончания вуза служил в должности заместителя по политической части учебного центра УВД МВД СССР по Аипецкой области. В 1986 году поступил в адъюнктуру Киевской высшей школы МВД СССР. Подготовиц диссертацию на соискание ученой степени кандидата юридических

* Комаров Сергей Александрович, научный руководитель Юридического института (Санкт-Петербург), профессор кафедры теории государства и права Института права Башкирского государственного университета, президент МОО «Межрегиональная ассоциация теоретиков государства и права", доктор юридических наук, профессор. E-mail: SVKomarov2008@yandex.ru 
наук на тему: «Воспитание правовой культуры у молодых сотрудников мимиции", защитил её в 1989 г. под научным руководством доктора юридических наук, профессора В.В. Копейчикова в Институте государства и права (г. Киев) по научной специальности 12.00.01 - теория и история права и государства, история учений о праве и государстве.

По распределению был направлен дия дальнейшего прохождения службы на кафедру государственно-правовых дисциплин Высшего политического учимища им. 60-летия В $\Lambda$ СМ МВД СССР в качестве преподавателя.

С 1997 по 2000 г. обучался в очной докторантуре Санкт-Петербургского университета МВД России. В 2000 г. защитил диссертацию на соискание ученой степени доктора юридических наук на тему: "Конституционный процесс: сравнительно-правовой анализ (на материалах Российской Федерации и зарубежных государств)".

Особо следует отметить роль В.В. Бородина в формировании юридических кадров ученых-юристов. Под его научным руководством были подготовлены и успешно защищены более двух десятков кандидатских диссертаций.

С 1993 по 2006 гг. бым учёным секретарем диссертационного совета на соискание ученой степени кандидата и доктора юридических наук. В этом диссовете прошии защиты диссертаций многих известных государственных и политических деятелей (С.В. Степашина, К.Б. Толкачева, А.Г. Хабибулина, С.А. Комарова и др.).

Неоднократно выполнял правительственные задачи в составе сводного батальона по предупреждению социальных конфииктов в горячих точках. В 1980 году участвовал в охране общественного порядка и безопасности XXII Омимпийских игр в Тацмине. Ветеран боевых действий. Награждён государственной наградой - медалью «За отиичную службу по охране общественного порядка", медамью Жукова, другими наградами.

В.В. Бородин известен как основоположник нового научного направцения в обцасти правоведения, связанного с теорией конституционного процесса. На основе докторского исследования им был разработан специальный курс - "Конституционный процесс", который вкцючен в учебные планы юридических вузов страны и ряда зарубежных государств.

Его перу принадлежит более 200 научных публикаций по проблемам правового государства и правовой культуры, конституционного права и конституционализма. Достаточно сослаться на ряд учебников, учебных пособий, монографий: “Основы Конституции Российской Федерации" [1]; "Конституционное право России" [2]; "Конституционный процесс как социальная реальность" [3]; "У истоков нормативной базы конституционного процесса" [4]; "Конституционный процесс: теория и практика" [5]; "Комментарий к Конституции РФ» [6]; “Ограничение конституционных прав и свобод человека в Российской Федерации: конституционно-правовой аспект" [7]; «Конституционный суд России и уставная юстиция в Российской Федерации (конституционно-правовой аспект)" [8] и др. 
B.В. Бородин принимает активное участие в подготовке аналитических и иных документов для обеспечения деятецьности Межпарламентской Ассамблеи СНГ (подготовка, например, проекта юридического словаря терминов и понятий, используемых в сфере государственного государства и местного самоуправцения.)

В настоящее время В.В. Бородин работает в должности профессора на кафедре конституционного и административного права Юридического института (Санкт-Петербург), пользуется заслуженным авторитетом.

Такой же яркий В.В. Бородин не только в науке, но и в жизни. Он

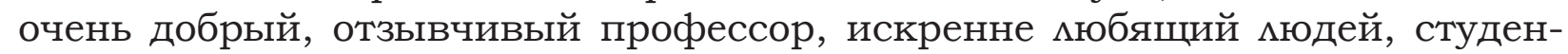
тов, слушателей, курсантов, аспирантов, адъюнктов.

Он удивительно не умеет змиться на мюдей, относится к ним с пони-

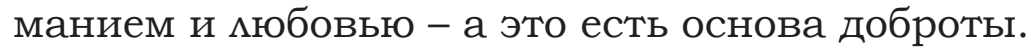

Юбиляр, кроме того, является оптимистом и жизнелюбом. На дачном своем участке создал комплекс теплиц по выращиванию овощей, а также

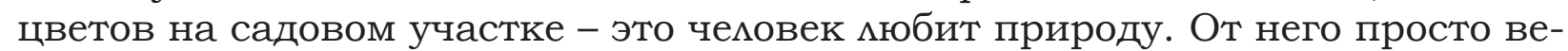
ет положительной энергией и стремлением жить полной жизнью.

От всего профессорско-преподавательского состава, комлектива Юридического института, членов редкомлегии журнала "Юридическая мысль", членов Межрегиональной ассоциации теоретиков государства и права, желаем дорогому Виктору Васицьевичу Бородину доцгих мет жизни, здоровья и удачи.

\section{Бибинографический список} 1996.

1. Бородин В.В. Основы Конституции Российской Федерации. - СПб.,

2. Бородин В.В. Конституционное право России. - СПб., 1997. Уфpa, 1998.

3. Бородин B.В. Конституционный процесс как социальная реальность. M., 1999.

4. Бородин В.В. У истоков нормативной базы конституционного процесса. 1999.

5. Бородин B.В. Конституционный процесс: теория и практика. - СПб.,

6. Бородин В. В. Комментарий к Конституции Российской Федерации: Постатейный / В.В. Бородин, В.П. Григонис, Э.П. Григонис. - СПб.: Питер, 2002. 194 c.

7. Бородин, В.В. Ограничение конституционных прав и свобод человека в Российской Федерации: конституционно-правовой аспект: монография / В.В. Бородин, А. В. Тарасов, В. И. Ушаков; МВД России, Санкт-Петербургский ун-т. - СПб.: Санкт-Петербургский ун-т МВД России, 2008. - 155 с.

8. Бородин B.B. Конституционный суд России и уставная юстиция в Российской Федерации (конституционно-правовой аспект). - СПб., 2016. - 128 с.

Дия цитирования: Комаров С.А. Виктору Васильевичу Бородину исполнилось 65 мет // Юридическая мысль. - 2021. - № 4 (124). - С. 185-187.

DOI: $10.47905 /$ MATGIP.2021.124.4.014 


\section{Viktor Vasilyevich Borodin is 65 years old}

\section{Sergey A. Komarov *}

Annotation. The article is dedicated to the anniversary of the Doctor of Law, Professor, Academician of the IAAS, Honored Lawyer of the Russian Federation, member of the Association of Lawyers of Russia, Colonel ext. service (retired) - Viktor Vasilyevich Borodin.

Key words: Borodin V.V., jurisprudence, legal sciences, legal culture.

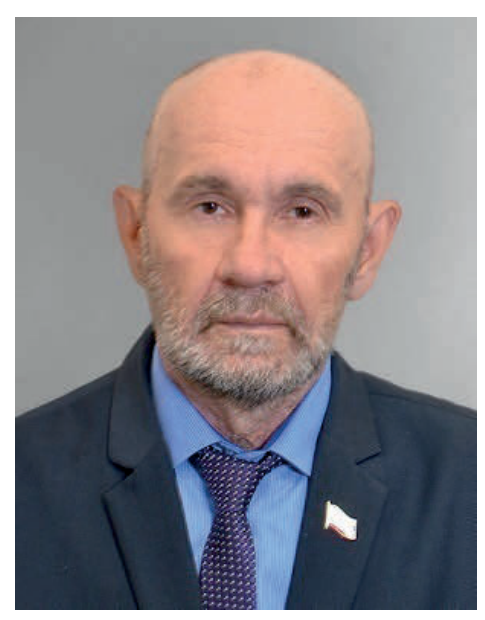

November 14, 2021 marks the 65th anniversary of the Honored Lawyer of the Russian Federation, member of the Russian Bar Association, member of the Interregional Association of State and Law Theorists, Doctor of Law, Professor, Academician of the IAAS, independent expert of the Constitutional Court of Russia, Police Colonel (retired) Viktor Vasilyevich Borodin. He celebrates a double anniversary - 65 years from the date of birth and 35 years of teaching activity.

V.V. Borodin was born in 1956 in the city of Lipetsk. In 1980 he graduated with honors from the Kaunas Secondary Special Police School of the USSR Ministry of Internal Affairs. In 1980-1981 he served as an operative of the OBKhSS in Lipetsk. In 1981 he entered the Higher Political School. 60th anniversary of the Komsomol of the Ministry of Internal Affairs of the USSR.

After graduation, he served as deputy for the political part of the training center of the Internal Affairs Directorate of the USSR Ministry of Internal Affairs in the Lipetsk region. In 1986 he entered the post-graduate course at the Kiev Higher School of the USSR Ministry of Internal Affairs. Prepared a dissertation for the degree of candidate of legal sciences on the topic: "Education of legal culture among young police officers", defended it in 1989 under the scientific supervision of Doctor of Law, Professor V.V. Kopeychikov at the Institute of State and Law (Kiev), specialty 12.00.01 - theory and history of law and state, history of doctrines about law and state.

According to the distribution, he was sent for further service at the Department of State and Legal Disciplines of the Higher Political School named after 60th anniversary of the Komsomol of the Ministry of Internal Affairs of the USSR as a teacher.

From 1997 to 2000 he studied in full-time doctoral studies at the St. Petersburg University of the Ministry of Internal Affairs of Russia. In 2000 he de-

* Komarov Sergey Aleksandrovich, scientific director of the Law Institute (St. Petersburg), professor of the Department of Theory of State and Law of the Institute of Law of the Bashkir State University, President of the Interregional Association of State and Law Theorists, Doctor of Law, Professor. E-mail: SVKomarov2008@yandex.ru 
fended his thesis for the degree of Doctor of Law on the topic: "Constitutional process: comparative legal analysis (based on the materials of the Russian Federation and foreign states)."

The role of V.V. Borodin in the formation of legal cadres of legal scholars. More than two dozen candidate dissertations were prepared and successfully defended under his scientific supervision.

1993 to 2006 was the scientific secretary of the dissertation council for the degree of candidate and doctor of legal sciences. In this dissertation council there were defenses of dissertations of many famous statesmen and political figures (S.V. Stepashin, K.B. Tolkachev, A.G. Khabibulin, S.A. Komarov, etc.).

Repeatedly performed government tasks as part of the combined battalion to prevent social conflicts in hot spots. In 1980 he took part in the maintenance of public order and security at the XXII Olympic Games in Tallinn. War veteran. He was awarded a state award - the medal "For excellent service in maintaining public order", the Zhukov medal, and other awards.

V.V. Borodin is known as the founder of a new scientific direction in the field of jurisprudence, associated with the theory of the constitutional process. On the basis of his doctoral research, he developed a special course - "Constitutional Process", which is included in the curricula of law schools of the country and a number of foreign countries.

He wrote more than 200 scientific publications on the problems of the rule of law and legal culture, constitutional law and constitutionalism. It is enough to refer to a number of textbooks, teaching aids, monographs: "Fundamentals of the Constitution of the Russian Federation" [1]; "Constitutional Law of Russia" [2]; "The constitutional process as a social reality" [3]; "At the origins of the normative base of the constitutional process" [4]; "Constitutional process: theory and practice" [5]; "Commentary on the Constitution of the Russian Federation" [6]; "Restriction of constitutional rights and freedoms of a person in the Russian Federation: constitutional and legal aspect" [7]; "The Constitutional Court of Russia and statutory justice in the Russian Federation (constitutional and legal aspect)" [8] and others.

V.V. Borodin takes an active part in the preparation of analytical and other documents to support the activities of the CIS Interparliamentary Assembly (preparation, for example, of a draft legal dictionary of terms and concepts used in the field of state state and local self-government.)

Currently V.V. Borodin works as a professor at the Department of Constitutional and Administrative Law of the Law Institute (St. Petersburg), enjoys a well-deserved prestige.

The same bright V.V. Borodin not only in science, but also in life. He is a very kind, sympathetic professor, sincerely loving people, students, listeners, cadets, graduate students, adjuncts.

He surprisingly does not know how to get angry with people, treats them with understanding and love - and this is the basis of kindness.

The hero of the day, moreover, is an optimist and a lover of life. At his summer cottage, he created a complex of greenhouses for growing vegetables, as well as flowers in a garden plot - this is a person who loves nature. He just blows with positive energy and the desire to live a full life. 
On behalf of the entire faculty, the staff of the Law Institute, members of the editorial board of the journal "Legal Thought", members of the Interregional Association of State and Law Theorists, we wish dear Viktor Vasilyevich Borodin many years of life, health and good luck.

\section{Bibliographic list}

1. Borodin V.V. Fundamentals of the Constitution of the Russian Federation. Saint Petersburg, 1996.

2. Borodin V.V. Constitutional law of Russia. Saint Petersburg, 1997.

3. Borodin V.V. The constitutional process as a social reality. Ufa, 1998.

4. Borodin V.V. At the origins of the normative base of the constitutional process. Moscow, 1999.

5. Borodin V.V. Constitutional process: theory and practice. Saint Petersburg, 1999.

6. Borodin V. V. Commentary to the Constitution of the Russian Federation: By-article / V.V. Borodin, V.P. Grigonis, E.P. Grigonis. Saint Petersburg: Peter, 2002. 194 p.

7. Borodin, V.V. Limitation of constitutional human rights and freedoms in the Russian Federation: constitutional and legal aspect: monograph / V. V. Borodin, A. V. Tarasov, V. I. Ushakov; Ministry of Internal Affairs of Russia, St. Petersburg University. Saint Petersburg: St. Petersburg University of the Ministry of Internal Affairs of Russia, 2008. 155 p.

8. Borodin V.V. Constitutional Court of Russia and statutory justice in the Russian Federation (constitutional and legal aspect). Saint Petersburg, 2016. 128 p.

For citation: Komarov S.A. Viktor Vasilyevich Borodin is 65 years old // Legal thought. 2021. No. 4 (124). P. 188-190.

DOI: 10.47905 / MATGIP.2021.124.4.014

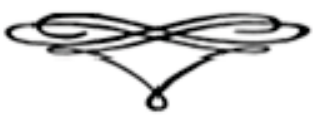




\title{
Удк 340.0
}

\section{Gергею Ивановнуу Захарцеву нсполнниось 45 мет"}

\author{
В.П. Бамьннков" \\ G.a. Komapoв ** \\ И.К. Конарат ${ }^{* * * *}$ \\ व.Г. ХаБнБу
}

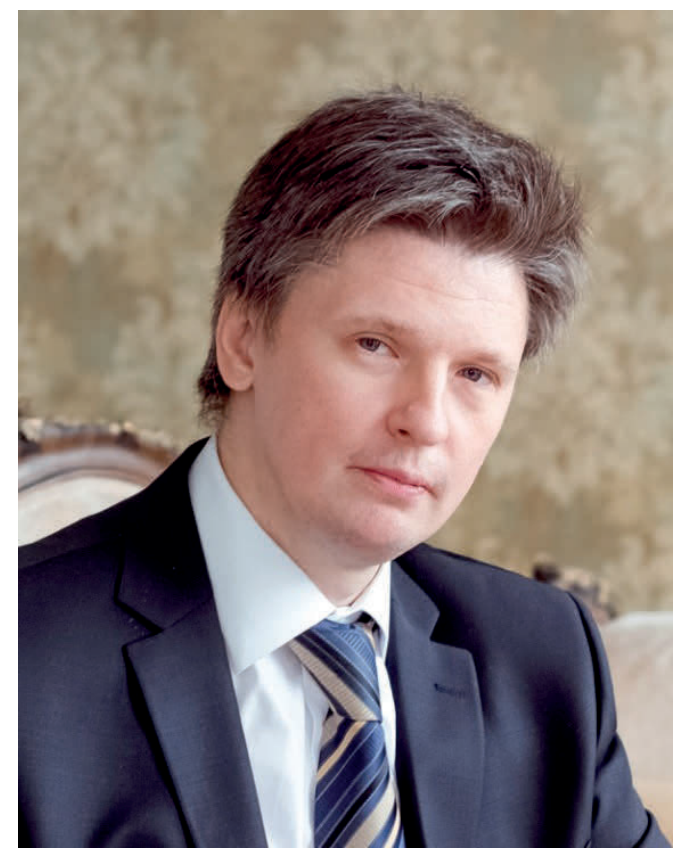

29 октября 2021 года отметил свое сорокапятилетие доктор юридических наук, профессор, академик Российской академии естественных наук Сергей Иванович Захарцев.

С.И. Захарцев родился в 1976 году

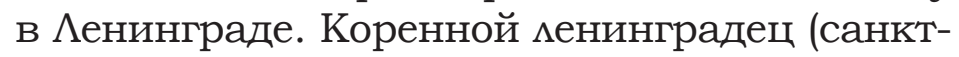
петербуржец). Его родители - Захарцевы Иван Иванович и Мариса Михайцовна инженеры, всю жизнь проработали на оборонном военно-космическом предприятии, имеют изобретения и государственные награды. Брат - Захарцев А^ексей Иванович известный в России и за рубежом радиожурналист.

С детства С.И. Захарцев мечтал посвятить свою жизнь защите Отчизны, слу-

* В статье использован материал, опубликованный в журнале "Теория государства и права", 2021, № 4 (DOI: 10.47905/MATGIP.2021.25.4.022)

** Сальников Виктор Петрович, доктор юридических наук, профессор, Заслуженный деятель науки Российской Федерации, Почетный работник высшего профессионального образования Российской Федерации, Почетный сотрудник МВД России, академик PAEH. E-mail: Fonduniver@bk.ru

*** Комаров Сергей Александрович, президент Межрегиональной ассоциации теоретиков государства и права, научный руководитель Юридического института (СанктПетербург), профессор кафедры теории государства и права Института права Башкирского государственного университета, доктор юридических наук, профессор. E-mail: svkomarov2008@ya.ru

**** Кондрат Иван Николаевич, профессор кафедры уголовного права, уголовного процесса и криминалистики МГИМО(У) МИД России, доктор юридических наук, професcop, Заслуженный юрист Российской Федерации, Почетный работник Прокуратуры Российской Федерации. E-mail: inkondrat@mail.ru

***** Хабибулин Алик Галимзянович, заведующий кафедрой экономических и финансовых расследований Высшей школы государственного аудита (факультета) Московского государственного университета им. М.В. Аомоносова, профессор кафедры теории государства и права и политологии юридического факультета МГУ им. М.В. Аомоносова, доктор юридических наук, профессор, Заслуженный юрист Республики Башкортостан, генерал-лейтенант полиции. E-mail: 21alik@mail.ru 
жению государству, борьбе с преступностью.

Следуя своей мечте, он после окончания средней школы поступим в Санкт-Петербургский юридический институт, который закончим в 1997 году.

После этого в том же 1997 году в возрасте 20 мет был призван на службу в органы федеральной службы безопасности. За короткий промежуток зарекомендовал себя талантливым сотрудником и начальником, подтверждением чему являлись государственные награды и поощрения руководства, присвоения воинских званий досрочно.

В 2008 году С.И. Захарцев был назначен на генеральскую домжность заместитель начальника Инспекторского управления ФСБ России. В 20082009 годах неоднократно исполнял обязанности начальника Инспекторского управцения ФСБ России.

Практическую работу С.И. Захарцев всегда успешно совмещал с научной и преподавательской деятельностью. В 2002 году он защитил диссертацию на соискание ученой степени кандидата юридических наук [30]. А уже через три года (в 2005 году) и тоже без отрыва от практической работы в ФСБ С.И. Захарцев защитил докторскую диссертацию по теме: "Теория и правовая регламентация оперативно-розыскных мероприятий" [31]. Эта защита установима своеобразный рекорд: С.И. Захарцев стал одним из самых молодых в истории России ученым, защитившим докторскую диссертацию по юридическим наукам.

Надо с сожалением сказать, что молодому ученому многие препятствовали защищаться именно из-за его возраста. После блестящей защиты в диссертационном совете Санкт-Петербургского университета МВД России, С.И. Захарцева пригласили в ВАК, где фактически пришлось защищаться еще раз. Но защита тоже прошла успешно. Экспертный совет ВАК, состоявший из наиболее уважаемых ученых, был приятно поражен глубиной и качеством диссертационной работы С.И. Захарцева.

С 2005 года стала формироваться новая научная школа изучения оперативно-розыскной деятельности, которая в дальнейшем была названа научной школой С.И. Захарцева.

Ранее практически все работы по ОРД несли на себе печать мибо научных подходов органов КГБ СССР, мибо МВД СССР. Работы С.И. Захарцева отличались тем, что они были написаны не на основе старых секретных учебников, а строго на основании Федерального закона "Об оперативнорозыскной деятельности" и другого оперативно-розыскного законодательства $[8 ; 11 ; 16 ; 21 ; 22 ; 23 ; 24 ; 25 ; 26 ; 27 ; 28 ; 29 ; 32 ; 33 ; 83]$. С.И. Захарцев назвал этот подход "юридическое ОРД".

С.И. Захарцев настаивал, что в юридической науке необходимо в первую очередь отталкиваться от закона, а не сложившейся практики и имевшегося опыта, который, причем не всегда, имел законный характер. Например, в науке ОРД диительное время существовало мнение о возможности использования незаконно полученных результатов ОРД в уголовном процессе, в том числе доказывании. Несложно предположить, что обосновывая допуск использования незаконно полученных результатов оперативно-розыскных мероприятий (да еще где - в уголовном судопроизводстве!), 
такие ученые, видимо, спокойно относились и к незаконному проведению мероприятий.

Именно С.И. Захарцев стоял у истоков категорической неприемлемости обоснований учеными-ордэшниками незаконных действий и попыткой выдачи их за законные. Работы С.И. Захарцева были высоко оценены юридическим сообществом, как научным, так и практическим. Книги С.И. Захарцева учат оперативников для получения необходимого результата четче соблюдать все установценные законом процедуры. В результате: у судей, прокуроров, следователей появицось большее доверие к ОРД и ее результатам.

Кроме того, С.И. Захарцевым была предложена новая структура науки ОРД, переформулированы основные понятия, сформулирована теория оперативно-розыскных мероприятий как открытая частная теория оперативно-розыскной деятельности. Ведь в уголовное судопроизводство на самом деле представляются результаты именно оперативно-розыскных мероприятий.

Хорошо про научную школу С.И. Захарцева написали специалисты: «Мы убеждены, что за подходом С.И. Захарцева будущее. И отрадно, что направцение под названием “юридическое ОРд” все больше получает поддержку в России. Подтверждением этому может служить все более распространяющееся в юридических вузах изучение правового регулирования ОРД. Еще недавно С.И. Захарцев в научной статье ставиц вопрос о том, что судья должен знать оперативно-розыскную деятельность, а теперь основы ОРД изучаются практически везде" [86, с. 178].

Большой заслугой С.И. Захарцева перед ОРД стало, если так можно выразиться, улучшение качественного состояния этой относительно молодой науки. О том, что научная школа С.И. Захарцева сейчас является ведущей в России ни у кого сомнений не вызывает $[1 ; 12 ; 13 ; 17 ; 18 ; 19 ; 67$; $68 ; 69 ; 72 ; 77 ; 78 ; 84 ; 85 ; 90 ; 91 ; 92 ; 93 ; 94]$.

Однако прикладные юридические дисциплины при всей их важности всегда находимись дмя С.И. Захарцева на втором месте. Аидирующее место в исследованиях ученого занимали и занимают проблемы философии права, теории права и, собственно, самой философии. И если работы С.И. Захарцева по ОРД изучаются, главным образом, внутри России, то труды по философии права вызвали интерес во всем мире. Так, в 2014 году С.И. Захарцев совместно с одним из авторов настоящей статьи обосновали и разработали компрехендную теорию права - новую философско-правовую теорию $[34 ; 35 ; 39 ; 40 ; 59 ; 97]$. Книги и статьи по названной теории переведены на ангмийский, немецкий, французский, итальянский, китайский, финский и другие языки мира. Книга "Фимософия. Фимософия права. Юридическая наука" издана в Кембридже, по ней учатся английские студенты [98].

Также большим спросом пользуется выпущенная в Англии и Италии монография С.И. Захарцева, Д.В. Масленникова и В.П. Сальникова "Аогос права: Парменид - Гегель - Достоевский. K вопросу о спекулятивномогических основаниях метафизики права" [37; 99]. Попумярны эти работы и в странах бывшего СССР: Украине, Беморуссии, Таджикистане, Казахстане и других. 
За последнее десятиметие С.И. Захарцев в соавторстве с В.П. Сальниковым обосновали авторское понимание фицософии права и ее предмета [47; 95]; доказали наличие правового прогресса и определили его критерии [48; 49]; рассмотрели различные грани права, в том числе проявления противоречивости, бессмысленности и глупости [50; 51], излишнего фрормализма, нередко встречающегося обвинительного уклона и другие стороны, на которые в силу ряда причин не обращают внимание ученые [36; 38].

В философии С.И. Захарцев и В.П. Сальников посвятили труды объективной истине, а также показали роль биографии ученого в формировании его отношения к истине. Кроме того, продемонстрировали запрограммированность общества и ее регулирование правом, проанализировали и установили особенности правовой ментальности и правового нигилизма россиян, ярко обосновали самодостаточность суверенитета русской философии права и суверенитета идеологии $[41 ; 42 ; 43 ; 44 ; 52 ; 53 ; 54 ; 55 ; 56 ; 57$; $58 ; 60 ; 87 ; 88 ; 89]$ !

В период пандемии особую остроту и актуальность получима в мировом научном сообществе разработанная авторами еще в 2015 году фияософская гипотеза катаклизмов и круговорота жизни на Земле. Сейчас эта гипотеза по понятным причинам очень попуяярна не только среди юристов, но и среди философов, физиков, работников медицины, других специалистов [45; 46].

Сейчас С.И. Захарцев является одним из наиболее заметных и цитируемых ученых-юристов. Он автор более 500 научных и учебно методических работ, из которых 24 монографии. Некоторые из них специалисты считают фундаментальными. В настоящее время С.И. Захарцев по рейтингам и индексу Хирша занимает пятое место по цитируемости его научных трудов среди всех юристов России (по состоянию на 1 сентября 2021 г. в системе РИНЦ зарегистрировано 37333 ученых-юристов)! Имеет индекс цитируемости трудов - 62! На его труды опубликованы десятки положительных рецензий $[2 ; 3 ; 4 ; 5 ; 6 ; 7 ; 9 ; 10 ; 14 ; 15 ; 20 ; 61 ; 62 ; 63 ; 64 ; 65$; $66 ; 70 ; 71 ; 73 ; 74 ; 75 ; 76 ; 79 ; 80 ; 81 ; 82 ; 96]$. Здесь обозначим томько некоторые из них.

В научном сообществе немало тех, кто считает С.И. Захарцева выдающимся ученым и юристом! К такому выводу мы присоединяемся. И добавим, что С.И. Захарцев с учетом его авторитета востребован не только как ученый, но и как руководитель научно-исследовательских комлективов.

Чем отличаются книги ученого от работ колмег? Мы бы особо выдемиАи несколько позиций.

Начнем с того, что С.И. Захарцев явцяется философом-практиком. Обычно философы, философы права и теоретики права занимаются исключительно научным и научно-преподавательским трудом, что отдаляет их от реалий и изменяет объективную картину. С.И. Захарцев всегда успешно совмещал философско-правовые исследования с работой ФСБ, а затем и в бизнесе.

При этом надо сказать, что служба в ФСБ на генеральских должностях давала возможность широкого доступа к информации и ее объективной оценке. Далеко не все философы имели и имеют возможности по полу- 
чению объективных и честных данных о происходящих событиях. Однако, как мы видим, мало кто из сотрудников подобных структур превращается в философа права, причем отстаивающего истину, справедливость и честность.

Отдельной позицией надо указать и то, что уже косвенно звучало. А именно то, что С.И. Захарцев в своих трудах всегда стремился к объективности сформулированных выводов. Он избегал одностороннего подхода к праву и истине. Этот ученый, если так можно выразиться, является фицософом-реалистом, не романтиком, а прагматиком. Он изнутри знал реальную работу правовых механизмов, а также видел, как такую работу умучшить.

Среди отАичий мы также выделим постоянную генерацию С.И. Захарцевым новых идей. Все его книги обосновывают или развивают новые теории, гипотезы, концепции. Причем все они вовсе не поверхностны, а содержательны и глубоки, обязательно могичны и аргументированы. Привнесением новых знаний в науку С.И. Захарцев, несомненно, оставиц в ней яркий след.

Талант С.И. Захарцева как ученого в сочетании с принципиальностью, объективностью и глубиной проведенных им исследований позволили ему завоевать авторитет и уважение у специалистов. Сейчас мало у кого в библиотеке не найдется хотя бы одной работы С.И. Захарцева.

Но это все касается науки. А в цичном пцане С.И. Захарцев - надежный друг, искренний чемовек, помнящий добро и не помнящий зма. Кроме того, замечательный муж, примерный семьянин и отец двух чудесных девочек.

Сорокапятилетний юбилей С.И. Захарцев встречает в расцвете своих творческих сиц. Мы ждем от него новых достижений. Пусть перо ученого никогда не притупляется. От всего сердца желаем Вам, дорогой Сергей Иванович, долгих мет жизни, здоровья, всего самого доброго. Пусть Ваше стремление вперед, стремление всегда и во всем быть мучшим никогда не пропадет!

\section{Бибциографический список}

1. Антонов И.А., Кондрат И.Н., Числов А.И, Шахматов А.В. Уголовный процесс и ОРД однозначно одинаково правовые науки. О вкладе профессора С.И. Захарцева в становление юридической оперативно-розыскной деятельности // Юридическая наука: история и современность. - 2019. - № 7. - С. 175-184.

2. Бабаджанов И.Х., Гаюров Ш.К., Тагайназаров Ш.Т. Русская философия права. Рецензия на монографию "Идея свободы. Право. Мораль (кмассическая и постклассическая фимософия права) / под ред. С.И. Захарцева. - М.: Юрлитинформ, 2020. - 288 с." // Правовая жизнь. № 4 (32) 2020. С. 247-258.

3. Баранов В.М., Баранова М.В. Инновационная трактовка права. Рецензия на монографию С.И. Захарцева "Право: новые идеи и прочтения" (М.: Юрлитинформ, 2021. 440 с.) // Юридическая наука и практика: Вестник Нижегородской академии МВД России. - 2021. - № 2 (54). - С. 248-251.

4. Баранов B.M. Российская книга по фимософии права и юриспруденции на английском языке. Рецензия-презентация монографии С.И. Захарцева и В.П. Саль- 
никова (The Philosophy of Law and Legal Science. Newcastle upon Tyne: Cambridge Scholars Publishing, 2018. 270 р.) // Юридическая наука и практика: Вестник Нижегородской академии МВД России. - 2018. - № 1 (41). - С. 304-307.

5. Баранов В.М., Баранова М.В. Нравственно-правовые проблемы идеи свободы в фокусе классической и неклассической философии права. Рецензия на монографию "Идея свободы. Право. Мораль (классическая и постклассическая философия права)" (под ред. С.И. Захарцева). М.: Юрлитинформ, 2020288 с.) // Вестник Нижегородской академии МВД России. - 2020. - № 4 (52). - С. 159-162.

6. Богатырев Д.К. От могоса к праву. Захарцев С.И., Масленников Д.В., Сальников В.П. Аогос права: Парменид - Гегель - Достоевский. К вопросу о спекумятивно-логических основаниях метафизики права: монография. - М.: Юрлитинформ, 2019. - 376 с. // Вестник Русской христианской гуманитарной академии. 2020. - № 1. - C. 352-360.

7. Борзова Е.П., Покровский И.Ф. Замечательная публикация в Кембридже уникальной книги. Рецензия на монографию С.И. Захарцева и В.П. Сальникова "Фимософия. Фимософия права. Юридическая наука" (М.: Юрлиинформ, 2015. 264 с.) и ее перевод: (S.I. Zakhartsev, V.P. Salnikov. The Philosophy of Law and Legal Science. Newcastle upon Tyne: Cambridge Scholars Publishing, 2018) // Мир политики и социологии. - 2018. - № 2. - С. 188-192.

8. Винниченко Н.А., Захариев С.И., Рохлин В.И. Правовая регламентация использования результатов оперативно-розыскной деятельности в уголовном судопроизводстве: Монография. Санкт-Петербургский университет МВД России; Академия права, экономики и безопасности жизнедеятельности / Под общ. ред. В.П. Сальникова. - СПб.: Фонд "Университет", 2004. - 176 с.

9. Галиев Ф.X., Раянов Ф.М. Когда рецензию писать не только приятно, но и почетно. О книге С.И. Захарцева и В.П. Сальникова "Фимософия. Философия права. Юридическая наука", переведенной на английский язык и изданной в Кембридже: Zakhartsev S.I., Salnikov V.P. The Philosophy of Law and Legal Science. Newcastle upon Tyne: Cambridge Scholars Publishing, 2018. 270 p. // Правовое государство: теория и практика. - 2018. - Т. 2. - № 52. - С. 206-208.

10. Галиев Ф.Х., Ислагилов Р.Ф., Сальников М.В. Актуальные проблемы науки о праве. Рецензия-размышления на монографию С.И. Захарцева "Право: новые идеи и прочтения. - М.: Юрлитинформ, 2021. - 440 с." // Правовое государство: теория и практика. - 2021. - № 2 (64). - C. 217-232. DOI 10.33184/pravgos2021.2.18.

11. Гвай А.М., Захариев С.И. Уголовная ответственность за убийства в контексте оперативно-розыскной деятельности и доказывания / Под ред. С.И. Захарцева. - М.: Юрлитинформ, 2021. - 272 с.

12. Голубовский В.Ю., Кондрат И.Н., Хабибулин А.Г., Числов А.И. Вклад профессора С.И. Захарцева в развитие уголовно-процессуальной и оперативнорозыскной науки // Мониторинг правоприменения. - 2020. - № 2 (35). C. 29-36.

13. Гук А.И., Игнашенков Ю.Ю., Числов А.И. Книга, давшая начало новой юридической науке и новым научным направлениям. Рецензия на монографию Захарцева С.И. «Наука оперативно-розыскной деятельности: фимософский, теоретико-правовой и прикладной аспекты" (СПб.: Издательский дом С-Петерб. гос унта, Издательство юридического факультета СПбГУ, 2011. 264 с.) // Юридическая наука: история и современность. - 2015. - № 9. - С. 138-143.

14. Двореикая Е.В., Кузнеиов Э.В. Сохраняя величие предмета. Рецензия на монографию С.И. Захарцева и В.П. Сальникова "Философия. Философия права. Юридическая наука" // Юридическая наука: история и современность. - 2016. № 11 . - С. 193-197. 
15. Двореикая Е.В., Масленников Д.В., Гук А.И. Вышла интересная книга о философии и праве. Рецензия на монографию С.И. Захарцева и В.П. Сальникова "Философия. Философия права. Юридическая наука" (М.: Юрлитинформ, 2015. 264 с.) // Мир политики и социологии. - 2016. - № 3. - С. 184-189.

16. Евстратиков Б.М., Захариев С.И., Медведев В.Н., Сальников В.П. Оперативно-розыскные мероприятия на каналах связи (правовой анализ): Монография. СПб.: Санкт-Петербургский университет МВД России; Академия права, экономики и безопасности жизнедеятельности / Под общ. ред. В.П. Сальникова. - СПб.: Фонд "Университет", 2005. - 256 с.

17. Егоршин В.М., Кондрат И.Н., Сурков К.В. Вышиа фундаментальная книга по оперативно-розыскной деятельности. Рецензия на монографию: Захарцев С.И., Вихров В.А., Игнащенков Ю.Ю., Сальников В.П. "Оперативно-розыскная деятельность и военная безопасность" (М.: Граница, 2017. 424 с.) // Юридическая наука: история и современность. - 2017. - № 4. - С. 132-138.

18. Егоршин В.М., Кондрат И.Н. Новый взгляд на науку оперативнорозыскной деятельности. Рецензия на монографию: Захарцев С.И., Вихров В.А., Игнащенков Ю.Ю., Сальников В.П. "Оперативно-розыскная деятельность и военная безопасность" (М.: Граница, 2017. 424 с. ) // Библиотека криминалиста. - Научный журнал. - 2018. - № 1 (36). - С. 373-377.

19. Егоршин В.М., Кондрат И.Н., Сурков К.В., Числов А.И. Новый взгляд на науку оперативно-розыскной деятельности. Рецензия на монографию: Захарцев С.И., Вихров В.А., Игнащенков Ю.Ю., Сальников В.П. "Оперативно-розыскная деятельность и военная безопасность" (М.: Граница, 2017. 424 с.) // Юридическая наука: история и современность. - 2017. - № 9. - С. 96-101.

20. Загоруйко К.Ф., Захариев С.И. Некоторые проблемы теории и философии права / Под ред. Сальникова В.П. - М.: Норма, 2014. - 207 с. // Социальные и гуманитарные науки. Отечественная и зарубежная митература. - Серия 4: Государство и право. - Реферативный журнал. - 2015- № 1. - С. 21-24.

21. Захариев С.И. Оперативно-розыскные мероприятия в России и за рубежом: Монография. Санкт-Петербургский университет МВД России, Академия права, экономики и безопасности жизнедеятельности / Под общ. ред. В.П. Сальникова. - СПб.: Фонд "Университет", 2003. - 256 с.

22. Захариев С.И. Оперативно-розыскные мероприятия. Общие положения: Монография. - СПб.: "Юридический центр «Пресс", 2004. - 259 с.

23. Захариев С.И., Медведев В.Н. Снятие информации с технических каналов связи: правовые вопросы. Монография. Санкт-Петербургский университет МВД России; Академия права, экономики и безопасности жизнедеятельности / Под общ. ред. В.П. Сальникова. - СПб.: Фонд “Университет», 2004. - 160 с.

24. Захариев С.И. Оперативно-розыскные мероприятия: Теория и практика / Под ред. В.П. Сальникова. - СПб.: Санкт-Петербургский университет МВД России, 2004. - 329 с.

25. Захариев С.И., Игнащенков Ю.Ю., Сальников В.П. Оперативно-розыскные мероприятия в XXI веке. - СПб.: Фонд "Университет», 2006. - 320 с.

26. Захариев С.И., Чабукиани О.А. Оперативно-розыскные мероприятия и следственные действия: понятия и соотношение: Монография. - СПб.: Санкт-Петербургский университет МВД России, 2010. - 268 с.

27. Захариев С.И. Наука оперативно-розыскной деятельности: философский, теоретико-правовой и прикладной аспекты. - СПб.: Издательский Дом С-Петерб. гос. ун-та, Издательство юридического факультета СПбГУ, 2011. - 264 с. DOI $10.17513 / \mathrm{np} .480$

28. Захариев С.И., Игнащенков Ю.Ю., Сальников В.П. Оперативно-розыскная деятельность в XXI веке. - М.: Норма, 2015. - 400 с. DOI 10.17513/np.469 
29. Захариев С.И., Вихров В.А., Игнащенков Ю.Ю., Сальников В.П. Оперативно-розыскная деятельность и военная безопасность / Под ред. С.И. Захарцева. М.: Граница, 2017. - 424 с.

30. Захариев С.И. Прослушивание телефонных переговоров в оперативнорозыскной деятельности и уголовном процессе. Дисс. ... канд. юрид. наук. - СПб., 2002.

31. Захариев С.И. Теория и правовая регламентация оперативно-розыскных мероприятий. Дисс. ... докт. юрид. наук. СПб., 2004.

32. Захариев С.И., Кирюшкина Н.О. Оперативно-розыскное право // Правовое поле современной экономики. - 2013. - № 9. - С. 187-192.

33. Захариев С.И., Кирюшкина Н.О. Новые фантомы оперативно-розыскной деятельности: оперативно-розыскная характеристика и оперативно-розыскной кодекс // Юридическая наука: история и современность. - 2013. - № 9. C. $94-101$.

34. Захариев С.И. Некоторые проблемы теории и фрилософии права / Под ред. В.П. Сальникова. - М.: Норма, 2014. - 208 с. DOI 10.17513/np.468

35. Захариев С.И., Сальников В.П. Философия. Фияософия права. Юридическая наука. - М.: Юрмитинформ, 2015. - 264 с. DOI 10.17513/np.454

36. Захариев С.И., Сальников В.П. Фимософия и юридическая наука. - М.: Юрлитинформ, 2019. - 424 с. DOI 10.17513/np.491.

37. Захариев С.И., Масленников Д.В., Сальников В.П. Аогос права: Парменид Гегель - Достоевский. К вопросу о спекулятивно-логических основаниях метафизики права. - М.: Юрмитинформ, 2019. - 376 с. DOI 10.17513/ np.467

38. Захариев С.И. Право: новые идеи и прочтения. - М.: Юрлитинформ, 2021. - 440 c. DOI $10.17513 /$ np.453

39. Захариев С.И., Сальников В.П. Компрехендная теория познания права // Юридическая наука: история и современность. 2015. № 8. С. 11-26.

40. Захариев С.И., Сальников В.П. Об обосновании компрехендного подхода для познания права // Теория государства и права. - 2016. - № 2. - С. 36-54.

41. Захариев С.И., Сальников В.П. О праве в программируемом обществе // Право и закон в программируемом обществе (к 100-летию со дня рождения Даниема Бемла): сборник научных статей / Т.Я. Хабриева, В.В. Аазарев, А.Я. Капустин и др.: отв. ред. В.В. Аазарев. - М.: Институт законодательства и сравнительного правоведения при Правительстве Российской Федерации; ИД «Юриспруденция", 2020. - С. 93-99.

42. Захариев С.И., Сальников В.П. Право в XXI веке в контексте запрограммированной жизни, информационных технологий и справедливосудия // Информационное право. - 2020. - № 3. - С. 9-15.

43. Захариев С.И., Сальников В.П. Запрограммированное общество и право // Стратегические приоритеты. - 2020. - № 3-4 (27-28). - С. 80-91.

44. Захариев С.И., Сальников В.П. Роль права в программировании жизни мюдей и их подконтрольности // Теория государства и права. - 2020. - № 3 (19). C. $86-102$.

45. Захариев С.И. Глобальные проблемы человечества и гипотеза катаклизмов и круговорота жизни на Земле // Контекст и рефмексия: философия о мире и человеке. - 2015. - № 4-5. - С. 9-23.

46. Захариев С.И., Сальников В.П. Тезисно о философских проблемах познания вселенной и Земли // Правовое поле современной экономики. - 2015. - № 10. C. 171-180.

47. Захариев С.И. Сальников В.П. Перечитывая Гегеля. Размышиения к 200-летию "Фимософии права" // Теория государства и права. - 2021. № 2 (22). - С. 6778. DOI: 10.47905/MATGIP.2021.22.2.005. 
48. Захариев С.И., Сальников В.П. Правовой прогресс - новая философскоправовая дефиниция / / Мир политики и социологии. - 2016. - № 4. - С. 171-188.

49. Захариев С.И., Сальников В.П. Правовой прогресс как актуальная философско-правовая проблема // Юридическая наука: история и современность. 2016. - № 9. - C. 175-192.

50. Захариев С.И., Сальников В.П. Право: разумность и бессмысленность // Юридическая наука: история и современность. - 2015. - № 9. - С. 17-22.

51. Захариев С.И., Сальников В.П. О разумности и бессмысленности права // Известия Российской академии ракетных и артимлерийских наук. - 2016. № 3 (93). - C. 179-183.

52. Захариев С.И., Сальников В.П. Продолжая дискуссию об истине // Мир политики и социологии. - 2016. - № 1. - С. 35-43.

53. Захариев С.И., Сальников В.П. Истина как проблема философии: классика или постмодернизм // Российский журнал правовых исследований. - 2016. № 2. - С. 96-100.

54. Захариев С.И., Сальников В.П., Сальников М.В. Проблема истины в праве и юридических науках // Юридическая наука: история и современность. - 2016. № 3. - С. 191-196.

55. Захариев С.И., Клименко О.А., Мирзоев А.К., Сальников М.В., Третьяков И.А. Суверенитет Российской Федерации: современные угрозы и обеспечение национальной безопасности // Юридическая наука: история и современность. - 2016. № 12. - C. 69-94.

56. Захариев С.И., Клименко О.А., Мирзоев А.К., Сальников М.В., Третьяков И.А. Суверенитет Российской Федерации: современные угрозы и обеспечение военной безопасности // Мир политики и социологии. - 2017. - № 1. - С. 120-139.

57. Захариев С.И., Сальников П.П., Кондрат Е.Н., Числов А.И. Финансовая безопасность и финансовый суверенитет России: современные проблемы // Юридическая наука: история и современность. - 2018. - № 1. - С. 128-132.

58. Захариев С.И., Сальников В.П. Размышиения об основах русской суверенной философско-правовой идеологии // Юридическая наука: история и современность. - 2020. - № 2. - С. 183-194.

59. Идея свободы. Право. Мораль (классическая и постклассическая фимософия права): Монография / Под ред. докт. юрид. наук С.И. Захарцева; И.А. Ананских, И.Н. Грибов, стр.И. Захарцев, Н.В. Зорина, И.Р. Исмагимов, О.А. Клименко, О.Ю. Аежнева, С.Ф. Мазурин, Б.В Маков, Д.В. Масленников, А.К. Мирзоев, П.А. Петров, Е.А. Поливко, К.Г. Прокофьев, О.В. Пьцева, В.П. Сальников, М.В. Сальников, Ф.О. Чудин-Курган. - М.: Юрмитинформ, 2020. - 288 с.

60. Исмагилов Р.Ф., Масленников Д.В., Сальников В.П., Захариев С.И., Сальников М.В., Петросян А.К., Черняева А.В. Идея справедливости в традициях постклассической философии права / Под общ. ред. В.П. Сальникова. - СПб.: Фонд "Университет", 2012. - 176 с.

61. Керимов А.Д., Масленников Д.В. Научная работа петербургских правоведов в перспективе суверенной философии права. Рецензия на монографию С.И. Захарцева и В.П. Сальникова "Фимософия и юридическая наука". М.: Юрлитинформ, 2019. 424 с. // Мониторинг правоприменения. - 2019. - № 4 (33). C. 14-18. DOI:10.21681/2226-0692-2019-4-14-18.

62. Керимов Д.А. В развитие дискуссии о фимософии и праве. Рецензия на монографию С.И. Захарцева и В.П. Сальникова "Философия. Философия права. Юридическая наука" - М.: Юрлитинформ, 2015. - 264 с. // Правовое поле современной экономики. - 2015. - № 1. - С. 68-73.

63. Керимова Т.В. Классическая монография о философии и праве. Рецензия на монографию С.И. Захарцева и В.П. Сальникова «Философия. Философия права. 
Юридическая наука" М.: Юрлитинформ, 2015. 264 с. // Юридическая наука: история и современность. -2016. - № 5. - С. 168-172.

64. Клименко А.И., Аебедев С.П. Спекулятивная метафизика права и творческое наследие Ф.М. Достоевского. Рецензия на монографию С.И. Захарцева, Д.В. Масленникова, В.П. Сальникова «Аогос права: Парменид - Гегель - Достоевский. К вопросу о спекулятивно-цогических основаниях метафизики права". М.: Юрлитинформ, 2019. 376 с. // Мониторинг правоприменения. - 2021. - № 1 (38). C. 61-64. DOI: 10.21681/2226-0692-2021-1-61-64. 07, п.м.

65. Колесников А.С., Масленников Д.В., Гук А.И. Размышления о фимософскоправовых работах С.И. Захарцева и своеобразии его фицософии // Юридическая наука: история и современность. - 2015. - № 12. - С. 177-184.

66. Комаров С.А., Хабибулин А.Г. Новая работа петербургских ученых по фицософии права // Теория государства и права. - 2020. - № 1 (17). - С. 193-208. DOI:10.25839/MATGIP.2020.17.1.018

67. Кондрат И.Н., Нахимов А.П., Сурков К.В. Наука оперативно-розыскной деятельности: взгляд в будущее. Рецензия на монографию Захарцева С.И., Ю.Ю. Игнащенкова и В.П. Сальникова "Оперативно-розыскная деятельность в XXI веке" (М.: Норма, 2015. 400 с.) // Юридическая наука: история и современность. 2015. - № 8. - C. 121-126.

68. Кондрат И.Н., Сальников В.П. О научных школах изучения оперативнорозыскной деятельности и месте школы С.И. Захарцева в изучении ОРД // Бибмиотека криминалиста. - Научный журнал. - 2016. - № 2 (25). - С. 370-377.

69. Кондрат И.Н., Сальников В.П. О научной школе изучения оперативнорозыскной деятельности профессора С.И. Захарцева // Юридическая наука: история и современность. - 2016. - № 2. - С. 96-103.

70. Кузнецов Э.В., Масленников Д.В., Покровский И.Ф., Экимов А.И. Английская версия российского издания S.I.Zakhartsev, V.P. Salnikov. The Philosophy of Law and Legal Science. Newcastle upon Tyne: Cambridge Scholars Publishing, 2018 // Юридическая наука: история и современность. - 2018. - № 9. - С. 191-194.

71. Аазарев В.В., Хабибулин А.Г. Истина философии и идея права: проблема единства (рецензия на монографию С.И. Захарцева, Д.В. Масленникова, В.П. Сальникова "Аогос права: Парменид - Гегель - Достоевский. К вопросу о спекулятивномогических основаниях метафизики права». М.: Юрлитинформ, 2019. 376 с.) // Журнал зарубежного законодательства и сравнительного правоведения. - 2021. T. 17. - № 3. - C. 151-157. DOI: 10.12737/jflcl.2021.036.

72. Маджидзода Д.М., Сальников В.П., Солиев К.Х. Научная школа профессора С.И. Захарцева - ведущая в России школа изучения оперативно-розыскной деятельности // Известия института философии, политологии и права им. А. Баховаддинова Академии наук Республики Таджикистан. - 2016. - № 4. - С. 153162.

73. Масленников Д.В., Степашин С.В. Рецензия на монографию С.И. Захарцева и В.П. Сальникова "Философия. Философия права. Юридическая наука" // Юридическая наука. - 2016. - № 6. - С. 177-179.

74. Масленников Д.В., Гук А.И., Числов А.И. Фимософско-правовые работы С.И. Захарцева: от происхождения права до перспектив правового бытия // Юридическая наука: история и современность. - 2016. - № 4. - С. 194-200.

75. Покровский И.Ф., Гук А.И. Когда философия и право снова вместе. Рецензия на монографию С.И. Захарцева "Некоторые проблемы теории и философии права" / Под ред. В.П. Сальникова. - М.: Норма, 2014. - 208 с. // Мир политики и социологии. - 2015. - № 7. - С. 184-190.

76. Покровский И.Ф., Исмагилов Р.Ф., Гук А.И. Действительно, философия и право снова вместе в исследовании современных научных мыслителей. Некоторые 
идеи по поводу рецензии Д.А. Керимова и монографии С.И. Захарцева и В.П. Сальникова "Фимософия. Философия права. Юридическая наука". - М.: Юрлитинформ, 2015. - 264 с. // Юридическая наука: история и современность. - 2015. - № 9. C. $196-200$.

77. Рахимзода Р.Х., Зоир Дж.М., Шарифзода Ф.Р. О вкладе выдающихся российских юристов Виктора Петровича Сальникова и Сергея Ивановича Захарцева в оперативно-розыскную науку // Труды Академии МВД Республики Таджикистан. - 2020. - № 2 (46). - С. 6-15.

78. Рахимзода Р.Х., Маджидзода Д.З., Солиев К.Х. Оперативно-разыскная помитика в контексте политики государства и оперативно-разыскной науки (рецензия на книгу "Захарцев С.И. Оперативно-розыскная деятельность в XXI веке: Моногр. / С.И. Захарцев, Ю.Ю. Игнащенков, В.П. Сальников. - М., Норма, 2015. 400 с.») // Оперативник (сыщик). - 2016. - № 4 (49). - С. 72-74.

79. Раянов Ф.М., Галиев Ф.Х. Фундаментальная философская книга о праве. Рецензия на монографию С.И. Захарцева, Д.В. Масленникова, В.П. Сальникова

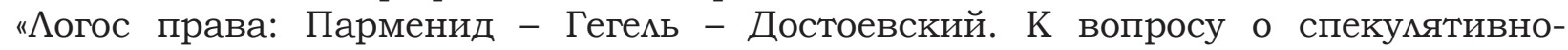
могических основаниях метафизики права. - М.: Юрмитинформ, 2019. - 376 с.» // Правовое государство: теория и практика. - 2019. -№ 2. С. 177-182

80. Раянов Ф.М., Галиев Ф.Х. Идея свободы в суверенной философии права. Рецензия на монографию: "Идея свободы. Право. Мораль (классическая и постклассическая философия права): Монография / Под ред. докт. юрид. наук С.И. Захарцева; И.А. Ананских, И.Н. Грибов, С.И. Захарцев, Н.В. Зорина, И.Р. Исмагияов, О.А. Клименко, О.Ю. Һежнева, С.Ф. Мазурин, Б.В Маков, Д.В. Масленников, А.К. Мирзоев, П.А. Петров, Е.А. Поливко, К.Г. Прокофьев, О.В. Пылева, В.П. Сальников, М.В. Сальников, Ф.О. Чудин-Курган. - М.: Юрлитинформ, 2020. 288 с." / / Правовое государство: теория и практика. - 2020. - № 1 (59). - С. 168-178.

81. Раянов Ф.М., Галиев Ф.Х. Поздравляем с выходом новой фундаментальной книги. Рецензия на монографию С.И. Захарцева и В.П. Сальникова "Философия и юридическая наука». - М.: Юрлитинформ, 2019. - 424 с. // Правовое государство: теория и практика. - 2019. - № 1 (55). - С. 181-188.

82. Романовская В.Б., Минеева Т.Г., Сальников В.П. Новое исследование в обмасти философии права. Рецензия на монографию «Идея свободы. Право. Мораль (классическая и постклассическая фрилософия права): Монография / Под ред. докт. юрид. наук С.И. Захарцева. - М.: Юрлитинформ, 2020 - 288 с.» // Юридическая наука: история и современность. - 2020. - № 1. - С. 185-193.

83. Рохлин В.И., Захариев С.И., Миронов М.А., Стуканов А.П. Институт реабимитации в российском законодательстве: возникновение, развитие, понятие, перспективы / Под ред. В.И. Рохлина. - СПб.: «Юридический центр «Пресс», 2007. 409 c.

84. Рохлин В.И. Фундаментальный труд по ОРД. Рецензия на монографию Захарцева С.И., Игнащенкова Ю.Ю. и Сальникова В.П. "Оперативно-розыскная деятельность в XXI веке" // Мир политики и социологии. - 2015. - № 1. - С. 151-157.

85. Рохлин В.И. Фундаментальная книга о настоящем и будущем оперативнорозыскной деятельности. Рецензия на монографию С.И. Захарцева, Ю.Ю. Игнащенкова и В.П. Сальникова "Оперативно-розыскная деятельность в XXI веке» (М.: Норма, 2015. - 400 с.) // Библиотека криминалиста. - Научный журнал. - 2015. № 4 (21). - С. 373-377.

86. Рохлин В.И. Оперативно-розыскная деятельность как философская, теоретическая и прикладная наука. Рецензия на книгу Захарцева С.И. Наука оперативно-розыскной деятельности: философский, теоретико-правовой и прикладной аспекты. - СПб., 2011 // Мир политики и социологии. - 2013. - № 11. C. $177-182$. 
87. Сальников В.П., Масленников Д.В., Захариев С.И., Морозов А.И. Ценностное основание суверенитета (к вопросу о суверенной государственно-правовой идеологии) // Юридическая наука: история и современность. - 2019. - № 11. C. $149-162$.

88. Сальников В.П., Масленников Д.В., Захариев С.И., Сальников М.В. Развитие идеи абсолютной свободы в классической русской философии как источник суверенной философии права / / Юридическая наука: история и современность. 2019. - № 12. - C. 185-193.

89. Сальников В.П., Масленников Д.В., Захариев С.И., Прокофьев К.Г., Морозов А.И. Принцип суверенности государственно-правовой идеологии и философии права / / Мир политики и социологии. - 2019. - № 9. - С. 170-178.

90. Сальников В.П., Кондрат И.Н., Антонов И.А., Хабибулин А.Г., Числов А.И. Новые научные специальности требуют иных подходов. Вышла книга, объединяющая проблемы уголовного права, оперативно-розыскной деятельности и угомовного процесса. Рецензия на монографию Гвай А.М. и Захарцева С.И. "Уголовная ответственность за убийства в контексте оперативно-розыскной деятельности и доказывания" / под ред. С.И. Захарцева. - М.: Юрлитинформ, 2021. - 272 с." // Юридическая наука: история и современность. - 2021. - № 5. - С. 134-141.

91. Сальников В.П., Степашин С.В., Числов А.И. История научной школы профессора С.И. Захарцева: от формирования до мидирующих позиций в науке оперативно-розыскной деятельности // Мир политики и социологии. - 2016. № 3. - C. 155-163.

92. Сальников В.П., Солиев К.Х., Хабибулин А.Г., Числов А.И. Научная школа профессора С.И. Захарцева или какой должна быть оперативно-розыскная деятельность // Правовое поле современной экономики. - 2016. - № 2. - С. 139-149.

93. Сальников В.П. Степашин С.В. Кондрат И.Н. Научная школа профессора С.И. Захарцева - взгляд в будущее оперативно-розыскной деятельности // Правовое государство: теория и практика. - 2016. - № 3 (45). - С. 155-165.

94. Cтепашин C.B., Егоршин B.M. Книга, опередившая время. Рецензия на монографию Захарцева С.И., Игнащенкова Ю.Ю. и Сальникова В.П. "Оперативно-розыскная деятельность в XXI веке" (М.: Норма, 2015. - 400 с.) // Юридическая наука: история и современность. - 2015. - № 1. - С. 119-125.

95. Теория государства и права в науке, образовании, практике: монография. Ю.Г., Арзамасов, В.М. Баранов, Н.В. Варламова и др.; пред ред. совета Т.Я. Хабриева; Институт законодательства и сравнительного правоведения при Правительстве Российской Федерации. - М.: Юриспруденция, 2016. С. 112-117.

96. Хабибулин А.Г., Мурсалимов К.Р. Рецензия на книгу С.И. Захарцева «Некоторые проблемы теории и философии права" / Под ред. В.П. Сальникова. - М.: Норма, 2014. - 208 с. // Мир политики и социологии. 2015. № 9. С. 203-209.

97. Захарцев C.I. Філософія і теорія права: Монографія / Передмова О.М. К^юева. - Харків: Панов, 2015. - 256 с. DOI 10.17513/np.471.

98. Zakhartsev S.I., Salnikov V.P. The Philosophy of Law and Legal Science. Newcastle upon Tyne: Cambridge Scholars Publishing, 2018. - 270 p. DOI 10.17513/np.452.

99. Zakhartsev S.I., Maslennikov D.V., Salnikov V.P.: The Logos of Law: Parmenides - Hegel - Dostoevsky. The Speculative and Logical Foundations of the Metaphysics of Law. - London: Europe Books. 2021. - 450 p. DOI 10.17513/np.490.

Дия цитирования: Сальников В.П., Комаров С.А., Кондрат И.Н., Хабибулин А.Г. Сергею Ивановичу Захарцеву исполнимось 45 мет // Теория государства и права. - 2021. № 4 (25). - C. 191-202.

DOI: $10.47905 /$ MATGIP.2021.25.4.022 


\section{Sergey Ivanovich Zakhartsev is $\mathbf{4 5}$ years old}

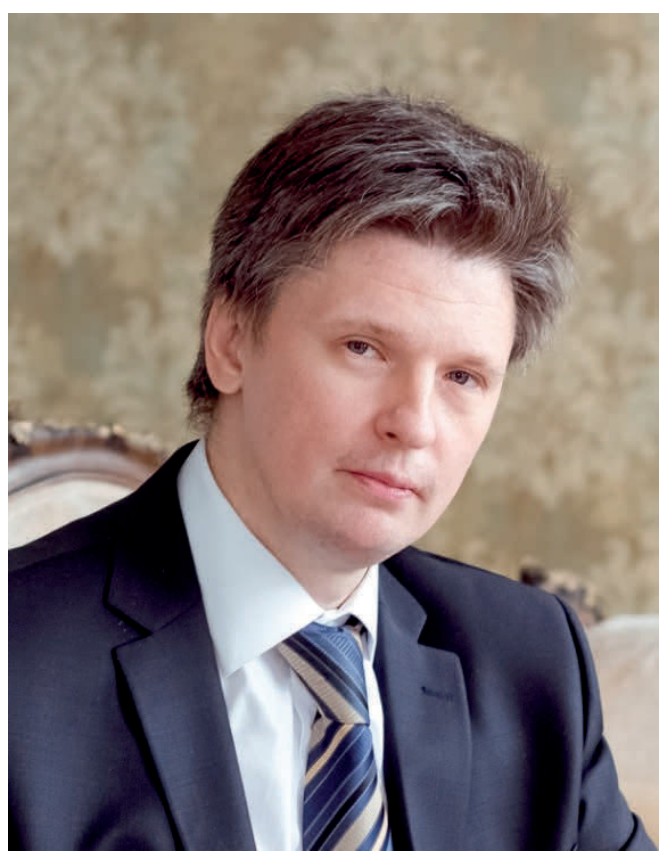

Following his dream, after graduating from high school, he entered the St. Petersburg Law Institute, which he graduated in 1997.

After that, in the same 1997, at the age of 20 , he was called up to serve in the federal security service. In a short period of time, he has established himself as a talented employee and chief, as evidenced by state awards and in-

* Salnikov Viktor Petrovich, Doctor of Law, Professor, Honored Scientist of the Russian Federation, Honorary Worker of Higher Professional Education of the Russian Federation, Honorary Officer of the Ministry of Internal Affairs of Russia, Academician of the Russian Academy of Natural Sciences. E-mail: Fonduniver@bk.ru

** Komarov Sergey Aleksandrovich, President of the Interregional Association of Theorists of State and Law, Scientific Director of the Law Institute (St. Petersburg), Professor of the Department of Theory of State and Law of the Institute of Law of the Bashkir State University, Doctor of Law, Professor. E-mail: svkomarov2008@ya.ru

*** Kondrat Ivan Nikolaevich, Professor of the Department of Criminal Law, Criminal Procedure and Criminalistics, MGIMO (U) of the Ministry of Foreign Affairs of Russia, Doctor of Law, Professor, Honored Lawyer of the Russian Federation, Honorary Worker of the Prosecutor's Office of the Russian Federation. E-mail: inkondrat@mail.ru

***** Khabibulin Alik Galimzyanovich, Head of the Department of Economic and Financial Investigations of the Higher School of State Audit (Faculty), Moscow State University. M.V. Lomonosov, Professor of the Department of Theory of State and Law and Political Science, Faculty of Law, Moscow State University. M.V. Lomonosov, Doctor of Law, Professor, Honored Lawyer of the Republic of Bashkortostan, Lieutenant General of Police. E-mail: 21alik@mail.ru 
centives for the leadership, and the assignment of military ranks ahead of schedule.

In 2008 S.I. Zakhartsev was appointed to the general's position - deputy head of the Inspection Directorate of the FSB of Russia. In 2008-2009, he repeatedly served as the head of the Inspection Directorate of the FSB of Russia.

Practical work of S.I. Zakhartsev has always successfully combined with scientific and teaching activities. In 2002 he defended his thesis for the degree of candidate of legal sciences [30]. And after three years (in 2005), and also without interrupting practical work in the FSB, S.I. Zakhartsev defended his doctoral dissertation on the topic: "Theory and legal regulation of operationalsearch measures" [31]. This defense set a kind of record: S.I. Zakhartsev became one of the youngest scientists in the history of Russia who defended his doctoral dissertation in legal sciences.

It must be said with regret that many prevented the young scientist from defending himself precisely because of his age. After a brilliant defense at the dissertation council of the St. Petersburg University of the Ministry of Internal Affairs of Russia, S.I. Zakhartsev was invited to the Higher Attestation Commission, where in fact he had to defend himself again. But the defense was also successful. The expert council of the Higher Attestation Commission, which consisted of the most respected scientists, was pleasantly impressed by the depth and quality of S.I. Zakhartseva.

Since 2005, a new scientific school for the study of operational-search activities began to form, which was later named the scientific school of S.I. Zakhartseva.

Previously, almost all work on independent reconnaissance patrols bore the stamp of either the scientific approaches of the KGB of the USSR, or the Ministry of Internal Affairs of the USSR. The works of S.I. Zakhartsev were distinguished by the fact that they were written not on the basis of old secret textbooks, but strictly on the basis of the Federal Law "On operational-search activity" and other operational-search legislation [8; eleven; sixteen; $21 ; 22 ; 23 ; 24 ; 25 ; 26 ; 27 ; 28$; 29; 32; 33; 83]. S.I. Zakhartsev called this approach "legal ORD".

S.I. Zakhartsev insisted that in legal science it is necessary, first of all, to build on the law, and not on the prevailing practice and experience, which, moreover, did not always have a legal character. For example, in the science of the ORD for a long time there was an opinion about the possibility of using the illegally obtained results of the ORD in the criminal process, including proving. It is not difficult to assume that when justifying the admission of the use of illegally obtained results of operational-search measures (and even where - in criminal proceedings!). Such scientists, apparently, were calm about the illegal conduct of measures.

It was S.I. Zakhartsev stood at the origins of the categorical unacceptability of justification by scientists-orders of illegal actions and an attempt to pass them off as legal. The works of S.I. Zakhartsev were highly appreciated by the legal community, both scientific and practical. Books by S.I. Zakhartsev teach operatives to better comply with all procedures established by law to obtain the required result. As a result: judges, prosecutors, and investigators gained more confidence in the ORD and its results. In addition, S.I. Zakhartsev 
proposed a new structure of the ORD science, reformulated the basic concepts, and formulated the theory of operational-search activities as an open private theory of operational-search activities. Indeed, it is the results of operationalsearch measures that are actually presented in criminal proceedings.

Good about the scientific school of S.I. Zakhartsev was written by experts: "We are convinced that the approach of S.I. Zakhartseva's future. And it is gratifying that the direction called "legal ORD" is receiving more and more support in Russia. This can be confirmed by the study of the legal regulation of OSA, which is becoming more and more widespread in law schools. More recently, S.I. Zakhartsev, in a scientific article, raised the question that a judge should know the operational-search activity, and now the basics of the ORD are studied practically everywhere" [86, p. 178].

Great merit of S.I. Zakhartsev before the ORD was, so to speak, an improvement in the qualitative state of this relatively young science. That the scientific school of S.I. Zakhartseva is now leading in Russia, no one doubts [1; $12 ; 13 ; 17 ; 18 ; 19 ; 67 ; 68 ; 69 ; 72 ; 77 ; 78 ; 84 ; 85 ; 90 ; 91 ; 92 ; 93 ; 94]$.

However, applied legal disciplines, for all their importance, have always been for S.I. Zakhartseva in second place. Problems of philosophy of law, theory of law and, in fact, philosophy itself occupy a leading place in the researches of the scientist. And if the works of S.I. Zakhartsev's studies on the ORD are studied mainly within Russia, then his works on the philosophy of law have aroused interest all over the world. So, in 2014 S.I. Zakhartsev, together with one of the authors of this article, substantiated and developed a comprehensive theory of law - a new philosophical and legal theory [34; 35; $39 ; 40 ; 59 ; 97]$. Books and articles on this theory have been translated into English, German, French, Italian, Chinese, Finnish and other languages of the world. The book "Philosophy. Philosophy of law. Jurisprudence" was published in Cambridge and is used by English students [98]. Also in great demand is the monograph by S.I. Zakhartseva, D.V. Maslennikov and V.P. Salnikov "Logos of law: Parmenides - Hegel - Dostoevsky. On the question of the speculativelogical foundations of the metaphysics of law" [37; 99]. These works are also popular in the countries of the former USSR: Ukraine, Belarus, Tajikistan, Kazakhstan and others.

Over the past decade, S.I. Zakhartsev in collaboration with V.P. Salnikov substantiated the author's understanding of the philosophy of law and its subject [47; 95]; proved the existence of legal progress and defined its criteria [48; 49]; considered various facets of law, including the manifestation of inconsistency, meaninglessness and stupidity [50; 51], excessive formalism, often encountered accusatory bias, and other parties that, for a number of reasons, do not pay attention to scientists [36; 38]. In the philosophy of S.I. Zakhartsev and V.P. Salnikov devoted their works to objective truth, and also showed the role of a scientist's biography in shaping his attitude to truth. In addition, they demonstrated the programmedness of society and its regulation by law, analyzed and established the peculiarities of the legal mentality and legal nihilism of Russians, vividly substantiated the self-sufficiency of the sovereignty of the Russian philosophy of law and the sovereignty of ideology $[41 ; 42 ; 43 ; 44 ; 52$; 53 ; $54 ; 55 ; 56 ; 57 ; 58 ; 60 ; 87 ; 88 ; 89]$ ! 
During a pandemic, the philosophical hypothesis of cataclysms and the cycle of life on Earth, developed by the authors back in 2015, received particular urgency and relevance in the world scientific community. Now, for obvious reasons, this hypothesis is very popular not only among lawyers, but also among philosophers, physicists, medical workers, and other specialists [45; 46].

Now S.I. Zakhartsev is one of the most prominent and cited legal scholars. He is the author of over 500 scientific and educational works, of which 24 are monographs. Some of them are considered fundamental by experts. According to ratings and the Hirsch index, Zakhartsev ranks fifth in the citation of his scientific works among all lawyers in Russia (as of September 1, 2021, 37333 legal scholars are registered in the RSCI system)! Has a citation index of works - 62! Dozens of positive reviews have been published on his works [2; 3; $4 ; 5 ; 6 ; 7 ; 9 ; 10 ; 14 ; 15$; twenty; $61 ; 62 ; 63 ; 64 ; 65 ; 66 ; 70 ; 71 ; 73 ; 74 ; 75 ; 76$; $79 ; 80 ; 81 ; 82 ; 96]$. Here we outline only a few of them.

There are many in the scientific community who consider S.I. Zakhartsev as an outstanding scientist and lawyer! We subscribe to this conclusion. And we add that S.I. Zakhartsev, taking into account his authority, is in demand not only as a scientist, but also as the head of research teams.

What is the difference between the scientist's books and the work of colleagues? We would highlight several positions.

Let's start with the fact that S.I. Zakhartsev is a practical philosopher. Usually philosophers, philosophers of law and theorists of law are exclusively engaged in scientific and scientific teaching work, which removes them from reality and changes the objective picture. S.I. Zakhartsev has always successfully combined philosophical and legal research with the work of the FSB, and then in business.

At the same time, it must be said that serving in the FSB as a general made it possible for wide access to information and its objective assessment. By no means all philosophers have had and still have the ability to obtain objective and honest data on current events. However, as we can see, few of the employees of such structures turn into a philosopher of law, moreover, defending truth, justice and honesty.

A separate position should also indicate what has already sounded indirectly. Namely, that S.I. Zakhartsev in his writings always strived for the objectivity of the formulated conclusions. He avoided a one-sided approach to law and truth. This scientist, so to speak, is a realist philosopher, not a romantic, but a pragmatist. He knew from the inside the real work of legal mechanisms, and also saw how to improve such work.

Among the differences, we also highlight the constant generation of S.I. Zakhartsev of new ideas. All his books substantiate or develop new theories, hypotheses, and concepts. Moreover, all of them are not superficial at all, but meaningful and deep, necessarily logical and reasoned. The introduction of new knowledge into the science of S.I. Zakhartsev, undoubtedly, left a bright mark on her.

The talent of S.I. Zakhartsev as a scientist, combined with the integrity, objectivity and depth of his research, allowed him to win the authority and respect of specialists. Nowadays, very few people in the library do not have at least one work by S.I. Zakhartseva. 
But this is all about science. And personally, S.I. Zakhartsev is a reliable friend, a sincere person who remembers well and does not remember evil. In addition, he is a wonderful husband, an exemplary family man and the father of two wonderful girls.

S.I. Zakhartsev meets in the prime of his creative powers. We expect new achievements from him. Let the scholar's pen never dull. With all our hearts, we wish you, dear Sergei Ivanovich, long life, health, and all the best. May your striving forward, striving always and in everything to be the best never disappear!

\section{Bibliographic list}

1. Antonov I.A., Kondrat I.N., Chislov A.I., Shakhmatov A.V. Criminal procedure and ORD are unambiguously equally legal sciences. On the contribution of Professor S.I. Zakhartseva in the formation of legal operational-search activity // Legal science: history and modernity. 2019. No. 7. P. 175-184.

2. Babadjanov I.Kh., Gayurov Sh.K., Tagainazarov Sh.T. Russian philosophy of law. Review of the monograph "The Idea of Freedom. Right. Moral (classical and postclassical philosophy of law) / ed. S.I. Zakhartseva. Moscow: Jurlitinform, 2020. 288 p." // Legal life. No. 4 (32) 2020, pp. 247-258.

3. Baranov V.M., Baranova M.V. Innovative interpretation of law. Review of the monograph by S.I. Zakhartseva "Law: New Ideas and Readings" (Moscow: Yurlitinform, 2021, 440 pp.) // Legal Science and Practice: Bulletin of the Nizhny Novgorod Academy of the Ministry of Internal Affairs of Russia. 2021. No. 2 (54). P. 248-251.

4. Baranov V.M. Russian book on philosophy of law and jurisprudence in English. Review-presentation of the monograph by S.I. Zakhartsev and V.P. Salnikova (The Philosophy of Law and Legal Science. Newcastle upon Tyne: Cambridge Scholars Publishing, 2018.270 p.) // Legal Science and Practice: Bulletin of the Nizhny Novgorod Academy of the Ministry of Internal Affairs of Russia. 2018. No. 1 (41). P. 304-307.

5. Baranov V.M., Baranova M.V. Moral and legal problems of the idea of freedom in the focus of classical and non-classical philosophy of law. Review of the monograph "The Idea of Freedom. Right. Morality (classical and postclassical philosophy of law) "(edited by SI Zakhartsev). Moscow: Yurlitinform, 2020288 p.) // Bulletin of the Nizhny Novgorod Academy of the Ministry of Internal Affairs of Russia. 2020. No. 4 (52). P. 159-162.

6. Bogatyrev D.K. From logo to right. Zakhartsev S.I., Maslennikov D.V., Salnikov V.P. Logos of law: Parmenides - Hegel - Dostoevsky. On the question of the speculative-logical foundations of the metaphysics of law: monograph. Moscow: Jurlitinform, 2019. 376 p. // Bulletin of the Russian Christian Humanitarian Academy. 2020. No. 1. P. 352-360.

7. Borzova E.P., Pokrovsky I.F. Wonderful publication in Cambridge of a unique book. Review of the monograph by S.I. Zakhartsev and V.P. Salnikov "Philosophy. Philosophy of law. Legal Science" (Moscow: Yurliinform, 2015. 264 p.) And its translation: (S.I. Zakhartsev, V.P. Salnikov. The Philosophy of Law and Legal Science. Newcastle upon Tyne: Cambridge Scholars Publishing, 2018) // World of Politics and Sociology ... 2018. No. 2. P. 188-192.

8. Vinnichenko N.A., Zakhartsev S.I., Rokhlin V.I. Legal regulation of the use of the results of operational-search activity in criminal proceedings: Monograph. St. Petersburg University of the Ministry of Internal Affairs of Russia; Academy of Law, Economics and Life Safety / Under total. ed. V.P. Salnikov. St. Petersburg: Fund "University", 2004. 176 p. 
9. Galiev F.Kh., Ryanov F.M. When it's not only pleasant to write a review, but also honorable. About S.I. Zakhartsev and V.P. Salnikov "Philosophy. Philosophy of law. Legal Science ", translated into English and published in Cambridge: Zakhartsev S.I., Salnikov V.P. The Philosophy of Law and Legal Science. Newcastle upon Tyne: Cambridge Scholars Publishing, 2018. 270 p. // Legal state: theory and practice. 2018. Vol. 2. No. 52, pp. 206-208.

10. Galiev F.Kh., Ismagilov R.F., Salnikov M.V. Actual problems of the science of law. Review-reflections on the monograph by S.I. Zakhartseva "Law: new ideas and readings. Moscow: Jurlitinform, 2021. 440 p." // Legal state: theory and practice. 2021. No. 2 (64). P. 217-232. DOI 10.33184 / pravgos-2021.2.18.

11. Gwai A.M., Zakhartsev S.I. Criminal liability for murder in the context of operational-search activity and evidence / Ed. S.I. Zakhartseva. Moscow: Yurlitinform, 2021. 272 p.

12. Golubovsky V.Yu., Kondrat I.N., Khabibulin A.G., Chislov A.I. Contribution of Professor S.I. Zakhartseva in the development of criminal procedural and operationalsearch science // Mo-nitoring of law enforcement. 2020. No. 2 (35). P. 29-36.

13. Guk A.I., Ignaschenkov Yu.Yu., Chislov A.I. The book that gave rise to a new legal science and new scientific directions. Review of the monograph by S.I. Zakhartsev "Science of operational-search activity: philosophical, theoretical and legal and applied aspects" (St. Petersburg: Publishing House of St. Petersburg State University, Publishing House of the Faculty of Law of St. Petersburg State University, 2011. 264 pp.) // Legal Science: History and Present ... 2015. No. 9. P. 138-143.

14. Dvoretskaya E.V., Kuznetsov E.V. Preserving the greatness of the subject. Review of the monograph by S.I. Zakhartsev and V.P. Salnikov "Philosophy. Philosophy of law. Legal science" // Legal science: history and modernity. 2016. No. 11. P. 193-197.

15. Dvoretskaya E.V., Maslennikov D.V., Guk A.I. An interesting book about philosophy and law has been published. Review of the monograph by S.I. Zakhartsev and V.P. Salnikov "Philosophy. Philosophy is right. Legal Science" (Moscow: Yurlitinform, 2015. 264 p.) // World of Politics and Sociology. 2016. No. 3. P. 184-189.

16. Evstratikov B.M., Zakhartsev S.I., Medvedev V.N., Salnikov V.P. Operationalsearch measures on communication channels (legal analysis): Monograph. - St. Petersburg University of the Ministry of Internal Affairs of Russia; Academy of Law, Economics and Life Safety / Under total. ed. V.P. Salnikov. St. Petersburg: Fund "University", 2005. 256 p.

17. Egorshin V.M., Kondrat I.N., Surkov K.V. A fundamental book on operational-search activity has been published. Review of the monograph: Zakhartsev S.I., Vikhrov V.A., Ignaschenkov Yu.Yu., Salnikov V.P. "Operational-search activity and military security" (Moscow: Granitsa, 2017. 424 p.) // Legal science: history and modernity. 2017. No. 4. P. 132-138.

18. Egorshin V.M., Kondrat I.N. A new look at the science of operational-search activity. Review of the monograph: Zakhartsev S.I., Vikhrov V.A., Ignaschenkov Yu.Yu., Salnikov V.P. "Operational-search activity and military security" (Moscow: Granitsa, 2017. 424 p.) // Criminalist Library. Science Magazine. 2018. No. 1 (36). P. 373-377.

19. Egorshin V.M., Kondrat I.N., Surkov K.V., Chislov A.I. A new look at the science of operational-search activity. Review of the monograph: Zakhartsev S.I., Vikhrov V.A., Ignaschenkov Yu.Yu., Salnikov V.P. "Operational-search activity and military security" (Moscow: Granitsa, 2017. 424 p.) // Legal science: history and modernity. 2017. No. 9. P. 96-101.

20. Zagoruiko K.F. 2015.01.004. Zakhartsev S.I. Some problems of theory and philosophy of law / Ed. Salnikova V.P. Moscow: Norma, 2014. 207 p. // Social and 
Human Sciences. Domestic and foreign literature. Series 4: State and Law. Abstract journal. 2015. No. 1. P. 21-24.

21. Zakhartsev S.I. Operational-search activities in Russia and abroad: Monograph. - St. Petersburg University of the Ministry of Internal Affairs of Russia, Academy of Law, Economics and Life Safety / Under total. ed. V.P. Salnikov. St. Petersburg: Fund "University", 2003. 256 p.

22. Zakhartsev S.I. Operational search activities. General provisions: Monography. St. Petersburg: "Legal Center" Press ", 2004. 259 p.

23. Zakhartsev S.I., Medvedev V.N. Removing information from technical communication channels: legal issues. Monograph. St. Petersburg University of the Ministry of Internal Affairs of Russia; Academy of Law, Economics and Life Safety / Under total. ed. V.P. Salnikov. St. Petersburg: Fund "University", 2004. 160 p.

24. Zakhartsev S.I. Operational-search activities: Theory and practice / Ed. V.P. Salnikov. St. Petersburg: Saint-Petersburg University of the Ministry of Internal Affairs of Russia, 2004. 329 p.

25. Zakhartsev S.I., Ignaschenkov Yu.Yu., Salnikov V.P. Operational-search measures in the XXI century. St. Petersburg: Fund "University", 2006. 320 p.

26. Zakhartsev S.I., Chabukiani O.A. Operational-search measures and investigative actions: concepts and correlation: Monograph. St. Petersburg: St. Petersburg University of the Ministry of Internal Affairs of Russia, 2010. 268 p.

27. Zakhartsev S.I. The science of operational-search activity: philosophical, theoretical-legal and applied aspects. St. Petersburg: Publishing House of St. Petersburg. state University, Publishing House of the Faculty of Law, St. Petersburg State University, 2011. 264 p. DOI 10.17513 / np.480

28. Zakhartsev S.I., Ignaschenkov Yu.Yu., Salnikov V.P. Operational-search activity in the XXI century. Moscow: Norma, 2015. 400 p. DOI 10.17513 / np.469

29. Zakhartsev S.I., Vikhrov V.A., Ignaschenkov Yu.Yu., Salnikov V.P. Operational-search activity and military security / Ed. S.I. Zakhartseva. Moscow: Granitsa, 2017. 424 p.

30. Zakhartsev S.I. Wiretapping of telephone conversations in operational-search activities and criminal proceedings. Dis. for the job ... Cand. jurid. sciences. St. Petersburg, 2002.

31. Zakhartsev S.I. Theory and legal regulation of operational-search measures. Dis. for the job ... doct. jurid. sciences. St. Petersburg, 2004.

32. Zakhartsev S.I., Kiryushkina N.O. Operational-investigative law // Legal field of modern economy. 2013. No. 9. P. 187-192.

33. Zakhartsev S.I., Kiryushkina N.O. New phantoms of operational-search activity: operational-search characteristics and operational-search code // Legal science: history and modernity. 2013. No. 9. P. 94-101.

34. Zakhartsev S.I. Some problems of theory and philosophy of law / Ed. V.P. Salnikov. Moscow: Norma, 2014. 208 p. DOI 10.17513 / np.468

35. 3. Zakhartsev S.I., Salnikov V.P. Philosophy. Philosophy of law. Legal science. Moscow: Yurlitinform, 2015. 264 p. DOI 10.17513 / np.454

36. Zakhartsev S.I., Salnikov V.P. Philosophy and legal science. Moscow: Yurlitin-form, 2019. 424 p. DOI 10.17513 / np.491.

37. Zakhartsev S.I., Maslennikov D.V., Salnikov V.P. Logos of law: Parmenides Hegel - Dostoevsky. On the question of the speculative-logical foundations of the metaphysics of law. Moscow: Jurlitinform, 2019. 376 p. DOI 10.17513 / np.467

38. Zakhartsev S.I. Right: new ideas and readings. Moscow:: Jurlitinform, 2021. 440 p. DOI 10.17513 / np.453

39. Zakhartsev S.I., Salnikov V.P. Comprehend theory of knowledge of law // Legal science: history and modernity. 2015. No. 8. P. 11-26. 
40. Zakhartsev S.I., Salnikov V.P. On the substantiation of a compromise approach for the knowledge of law // Theory of State and Law. 2016. No. 2. P. 36-54.

41. Zakhartsev S.I., Salnikov V.P. On law in a programmed society // Law and law in a programmed society (to the 100th anniversary of the birth of Daniel Bell): collection of scientific articles / T.Ya. Khabrieva, V.V. Lazarev, A. Ya. Kapustin and others: otv. ed. V.V. Lazarev. Moscow: Institute of Legislation and Comparative Law under the Government of the Russian Federation; Publishing House "Jurisprudence", 2020. P. 93-99.

42. Zakhartsev S.I., Salnikov V.P. Law in the XXI century in the context of a programmed life, information technology and justice // Information law. 2020. No. 3. P. 9-15.

43. Zakhartsev S.I., Salnikov V.P. Programmed society and law // Strategic priorities. 2020. No. 3-4 (27-28). P. 80-91.

44. Zakhartsev S.I., Salnikov V.P. The role of law in programming people's lives and their control // Theory of state and law. 2020. No. 3 (19). P. 86-102.

45. Zakhartsev S.I. Global problems of mankind and the hypothesis of cataclysms and the cycle of life on Earth // Context and reflection: philosophy about the world and man. 2015. No. 4-5. P. 9-23.

46. Zakhartsev S.I., Salnikov V.P. Thesis on the philosophical problems of cognition of the universe and the Earth // Legal field of modern economics. 2015. No. 10. P. 171-180.

47. Zakhartsev S.I. Salnikov V.P. Rereading Hegel. Reflections on the 200th anniversary of the "Philosophy of Law" // Theory of State and Law. 2021. No. 2 (22). P. 67-78. DOI: 10.47905 / MATGIP.2021.22.2.005.

48. Zakhartsev S.I., Salnikov V.P. Legal progress - a new philosophical and legal definition // World of Politics and Sociology. 2016. No. 4. P. 171-188.

49. Zakhartsev S.I., Salnikov V.P. Legal progress as an actual philosophical and legal problem // Legal science: history and modernity. 2016. No. 9. P. 175-192.

50. Zakhartsev S.I., Salnikov V.P. Law: rationality and meaninglessness // Legal science: history and modernity. 2015. No. 9. P. 17-22.

51. Zakhartsev S.I., Salnikov V.P. On the rationality and meaninglessness of law // News of the Russian Academy of Rocket and Artillery Sciences. 2016. No. 3 (93). P. 179-183.

52. Zakhartsev S.I., Salnikov V.P. Continuing the discussion about the truth // World of Politics and Sociology. 2016. No. 1. P. 35-43.

53. Zakhartsev S.I., Salnikov V.P. Truth as a problem of philosophy: classics or postmodernism // Russian Journal of Legal Research. 2016. No. 2. P. 96-100.

54. Zakhartsev S.I., Salnikov V.P., Salnikov M.V. The problem of truth in law and legal sciences // Legal science: history and modernity. 2016. No. 3. P. 191-196.

55. Zakhartsev S.I., Klimenko O.A., Mirzoev A.K., Salnikov M.V., Tretyakov I.L. Sovereignty of the Russian Federation: modern threats and ensuring national security // Legal science: history and modernity. 2016. No. 12. P. 69-94.

56. Zakhartsev S.I., Klimenko O.A., Mirzoev A.K., Salnikov M.V., Tretyakov I.L. Sovereignty of the Russian Federation: Modern Threats and Ensuring Military Security // World of Politics and Sociology. 2017. No. 1. P. 120-139.

57. Zakhartsev S.I., Salnikov P.P., Kondrat E.N., Chislov A.I. Financial security and financial sovereignty of Russia: modern problems // Legal science: history and modernity. 2018. No. 1. P. 128-132.

58. Zakhartsev S.I., Salnikov V.P. Reflections on the Foundations of Russian Sovereign Philosophical and Legal Ideology // Legal Science: History and Modernity. 2020. No. 2. P. 183-194.

59. The idea of freedom. Right. Morality (classical and postclassical philosophy of law): Monograph / Ed. doct. jurid. Sciences S.I. Zakhartseva; I.A. Ananskikh, I.N. Gri- 
bov, page I. Zakhartsev, N.V. Zorina, I.R. Ismagilov, O. A. Klimenko, O. Yu. Lezhneva, S.F. Mazurin, B.V. Makov, D.V. Maslennikov, A.K. Mirzoev, P.A. Petrov, E.A. Polivko, K.G. Prokofiev, O. V. Pyle-va, V.P. Salnikov, M.V. Salnikov, F.O. Chudin-Kurgan. Mowcow: Jurlitinform, 2020. 288 p.

60. Ismagilov R.F., Maslennikov D.V., Salnikov V.P., Zakhartsev S.I., Salnikov M.V., Petrosyan L.K., Chernyaeva A.V. The Idea of Justice in the Traditions of Postclassical Philosophy of Law / Ed. ed. V.P. Salnikov. St.Petersburg: Fund "University", 2012. 176 p.

61. Kerimov A.D., Maslennikov D.V. Scientific work of St. Petersburg jurists in the perspective of the sovereign philosophy of law. Review of the monograph by S.I. Zakhartsev and V.P. Salnikov "Philosophy and Legal Science". Moscow: Yurlitinform, 2019.424 p. // Monitoring of law enforcement. 2019. No. 4 (33). P. 14-18. DOI: 10.21681 / 2226-0692-2019-4-14-18.

62. Kerimov D.A. In the development of a discussion about philosophy and law. Review of the monograph by S.I. Zakhartsev and V.P. Salnikov "Philosophy. Philosophy of law. Legal Science". Moscow: Yurlitinform, 2015. 264 p. // Legal field of modern economy. 2015. No. 1. P. 68-73.

63. Kerimova T.V. Classical monograph on philosophy and law. Review of the monograph by S.I. Zakhartsev and V.P. Salnikov "Philosophy. Philosophy of law. Legal Science". Moscow: Yurlitinform, 2015. 264 p. // Legal science: history and modernity. 2016. No. 5. P. 168-172.

64. Klimenko A.I., Lebedev S.P. Speculative metaphysics of law and the creative heritage of F.M. Dostoevsky. Review of the monograph by S.I. Zakhartseva, D.V. Maslennikova, V.P. Salnikov "Logos of law: Parmenides - Hegel - Dostoevsky. On the question of the speculative-logical foundations of the metaphysics of law". Moscow: Yurlitinform, 2019. 376 p. // Monitoring enforcement. 2021. No. 1 (38). P. 61-64. DOI: 10.21681 / 2226-0692-2021-1-61-64. 07, p.1.

65. Kolesnikov A.S., Maslennikov D.V., Guk A.I. Reflections on the philosophical and legal works of S.I. Zakhartsev and the originality of his philosophy // Legal science: history and modernity. 2015. No. 12. P. 177-184.

66. Komarov S.A., Khabibulin A.G. New work of St. Petersburg scientists on the philosophy of law // Theory of state and law. 2020. No. 1 (17). P. 193-208. DOI: 10.25839 / MATGIP.2020.17.1.018

67. Kondrat I.N., Nakhimov A.P., Surkov K.V. The science of operational-search activity: a look into the future. Review of the monograph by S.I. Zakhartsev, Yu.Yu. Ignaschenkov and V.P. Salnikov "Operational-search activity in the XXI century" (Moscow: Norma, 2015. 400 p.) // Legal science: history and modernity. 2015. No. 8. P. 121-126.

68. Kondrat I.N., Salnikov V.P. About scientific schools for the study of operational-search activities and the place of the school of S.I. Zakhartseva in the study of the ORD / / Library of the criminalist. Science Magazine. 2016. No. 2 (25). P. 370-377.

69. Kondrat I.N., Salnikov V.P. On the scientific school for the study of operational-search activities of Professor S.I. Zakhartseva // Legal science: history and modernity. 2016. No. 2. P. 96-103.

70. Kuznetsov E. V., Maslennikov D. V., Pokrovsky I. F., Ekimov A. I. The English version of the Russian edition S.I. Zakhartsev, V.P. Salnikov. The Philosophy of Law and Legal Science. Newcastle upon Tyne: Cambridge Scholars Publishing, 2018 // Legal Science: History and Modernity. 2018. No. 9. P. 191-194.

71. Lazarev V.V., Khabibulin A.G. The truth of philosophy and the idea of law: the problem of unity (review of the monograph by S.I. Zakhartsev, D.V. Maslennikov, V.P. Salnikov "Logos of law: Parmenides - Hegel - Dostoevsky. On the speculative and logical foundations of the metaphysics of law". Moscow: Jurlitinform, 2019. 376 p.) // 
Journal of foreign legislation and comparative jurisprudence. 2021. Vol. 17. No. 3. P. 151-157. DOI: 10.12737 / jflcl.2021.036.

72. Madzhidzoda D.M., Salnikov V.P., Soliev K.Kh. Scientific school of professor S.I. Za-khartseva - the leading school for the study of operational-search activity in Russia // News of the Institute of Philosophy, Political Science and Law named after V.I. A. Bakhovaddinova of the Academy of Sciences of the Republic of Tajikistan. 2016. No. 4. P. 153-162.

73. Maslennikov D.V., Stepashin S.V. Review of the monograph by S.I. Zakhartsev and V.P. Salnikov "Philosophy. Philosophy of law. Legal Science" // Legal Science. 2016. No. 6. P. 177-179.

74. Maslennikov D.V., Guk A.I., Chislov A.I. Philosophical and legal works of S.I. Zakhartseva: from the origin of law to the prospects of legal existence // Legal science: history and modernity. 2016. No. 4. P. 194-200.

75. Pokrovsky I.F., Guk A.I. When philosophy and law are together again. Review of the monograph by S.I. Zakhartseva "Some problems of theory and philosophy of law" / Ed. V.P. Salnikov. Moscow: Norma, 2014. 208 p. // The world of politics and sociology. 2015. No. 7. P. 184-190.

76. Pokrovsky I.F., Ismagilov R.F., Guk A.I. Indeed, philosophy and law are together again in the study of modern scientific thinkers. Some ideas about the review by D.A. Kerimov and monographs by S.I. Zakhartsev and V.P. Salnikov "Philosophy. Philosophy of law. Legal Science". Moscow: Yurlitinform, 2015. 264 p. // Legal science: history and modernity. 2015. No. 9. P. 196-200.

77. Rakhimzoda R.Kh., Zoir J.M., Sharifzoda F.R. On the contribution of prominent Russian lawyers Viktor Petrovich Salnikov and Sergei Ivanovich Zakhartsev to operational-search science // Proceedings of the Academy of the Ministry of Internal Affairs of the Republic of Tajikistan. 2020. No. 2 (46). P. 6-15.

78. Rakhimzoda R.Kh., Madzhidzoda D.Z., Soliev K.Kh. Operational-search policy in the context of state policy and operational-search science (review of the book "Zakhartsev S.I. P. Salnikov. M., Norma, 2015. - 400 p.") // Operative (detective). 2016. No. 4 (49). P. $72-74$.

79. Ryanov F.M., Galiev F.Kh. Fundamental philosophical book about law. Review of the monograph by S.I. Zakhartseva, D.V. Maslennikova, V.P. Salnikov "Logos of law: Parmenides - Hegel - Dostoevsky. On the question of the speculative-logical foundations of the metaphysics of law. Moscow: Jurlitinform, 2019.376 p." // Legal state: theory and practice. 2019. No. 2. P. 177-182

80. Ryanov F.M., Galiev F.Kh. The idea of freedom in the sovereign philosophy of law. Review of the monograph: "The idea of freedom. Right. Morality (classical and postclassical philosophy of law): Monograph / Ed. doct. jurid. Sciences S.I. Zakhartseva; I.A. Ananskikh., I.N. Gribov, S.I. Zakhartsev, N.V. Zorina, I.R. Ismagilov, O. A. Klimenko, O. Yu. Lezhnev, p. F. Mazurin, B.V. Makov, D.V. Maslennikov, A.K. Mirzoev, P.A. Petrov, E.A. Polivko, K.G. Prokofiev, O. V. Pyleva, V.P. Salnikov, M.V. Salnikov, F.O. Chudin-Kurgan. Moscow: Jurlitinform, 2020. 288 p." // Legal state: theory and practice. 2020. No. 1 (59). P. 168-178.

81. Ryanov F.M., Galiev F.Kh. Congratulations on the release of your new fundamental book. Review of the monograph by S.I. Zakhartsev and V.P. Salnikov "Philosophy and Legal Science". Moscow: Yurlitinform, 2019. 424 p. // Legal state: theory and practice. 2019. No. 1 (55). P. 181-188.

82. Romanovskaya V.B., Mineeva T.G., Salnikov S.P. New research in the field of philosophy of law. Review of the monograph "The Idea of Freedom. Right. Morality (classical and postclassical philosophy of law): Monograph / Ed. doct. jurid. Sciences S.I. Zakhartseva. Moscow: Jurlitinform, 2020. 288 p." // Legal science: history and modernity. 2020. No. 1. P. 185-193. 
83. Rokhlin V.I., Zakhartsev S.I., Mironov M.A., Stukanov A.P. Institute of rehabilitation in Russian legislation: emergence, development, concept, prospects / Ed. IN AND. Rokhlina. St.Petersburg: "Legal Center "Press", 2007. 409 p.

84. Rokhlin V.I. Fundamental work on the ORD. Review of the monograph by S.I. Zakhartsev, Yu.Yu. Ignashchenkov and Salnikova V.P. "Operational-search activity in the XXI century" // World of politics and sociology. 2015. No. 1. P. 151-157.

85. Rokhlin V.I. Fundamental book about the present and future of operationalsearch activities. Review of the monograph by S.I. Zakhartseva, Yu. Ignaschenkov and V.P. Salnikov "Operational-search activity in the XXI century" (Moscow: Norma, 2015. 400 p.) // Criminalist Library. Science Magazine. 2015. No. 4 (21). P. 373-377.

86. Rokhlin V.I. Operational-search activity as a philosophical, theoretical and applied science. Review of the book by S.I. Zakhartsev The science of operationalsearch activity: philosophical, theoretical and legal and applied aspects. St.Petersburg, 2011 // World of Politics and Sociology. 2013. No. 11. P. 177-182.

87. Salnikov V.P., Maslennikov D.V., Zakhartsev S.I., Morozov A.I. The value basis of sovereignty (on the issue of sovereign state-legal ideology) // Legal science: history and modernity. 2019.No. 11. P. 149-162.

88. Salnikov V.P., Maslennikov D.V., Zakhartsev S.I., Salnikov M.V. Development of the idea of absolute freedom in classical Russian philosophy as a source of sovereign philosophy of law // Legal science: history and modernity. 2019. No. 12. P. 185-193.

89. Salnikov V.P., Maslennikov D.V., Zakhartsev S.I., Prokofiev K.G., Morozov A.I. The principle of sovereignty of state-legal ideology and philosophy of law // World of politics and sociology. 2019. No. 9. P. 170-178.

90. Salnikov V.P., Kondrat I.N., Antonov I.A., Khabibulin A.G., Chislov A.I. New scientific specialties require different approaches. A book has been published that combines the problems of criminal law, operational-search activity and criminal procedure. Review of the monograph by A.M. Guay and Zakhartseva S.I. "Criminal liability for murder in the context of operational-search activities and evidence" / ed. S.I. Zakhartseva. Moscow: Jurlitinform, 2021. 272 p." // Legal science: history and modernity. 2021. No. 5. P.134-141.

91. Salnikov V. P., Stepashin S. V., Chislov A. I. The history of the scientific school of Professor S.I. Zakhartseva: from formation to leading positions in the science of operational-search activity // World of Politics and Sociology. 2016. No. 3. P. 155-163.

92. Salnikov V.P., Soliev K.Kh., Khabibulin A.G., Chislov A.I. Scientific school of professor S.I. Zakhartseva or what should be the operational-search activity // Legal field of modern economics. 2016. No. 2. P. 139-149.

93. Salnikov V.P., Stepashin S.V. Kondrat I.N. Scientific school of professor S.I. Zakhartseva - a look into the future of operational-search activity // Legal state: theory and practice. 2016. No. 3 (45). P. 155-165.

94. Stepashin S.V., Egorshin V.M. A book ahead of its time. Review of the monograph by S.I. Zakhartsev, Yu.Yu. Ignaschenkov and Salnikova V.P. "Operationalsearch activity in the XXI century" (Moscow: Norma, 2015. 400 p.) // Legal science: history and modernity. 2015. No. 1. P. 119-125.

95. Theory of state and law in science, education, practice: monograph. Yu.G. Arzamasov, V.M. Baranov, N.V. Varlamov and others; before ed. council T.Ya. Khabrieva; Institute of Legislation and Comparative Law under the Government of the Russian Federation. Moscow: Jurisprudence, 2016. P. 112-117.

96. Khabibulin A.G., Mursalimov K.R. Review of the book by S.I. Zakhartseva "Some problems of theory and philosophy of law" / Ed. V.P. Salnikov. Moscow: Norma, 2014. 208 p. // The world of politics and sociology. 2015. No. 9. P. 203-209.

97. Zakhartsev S.I. Philosophy and theory of law: Monograph / Peredmova O.M. Klyuev. Kharkiv: Panov, 2015. 256 p. DOI 10.17513 / np.471. 
98. Zakhartsev S.I., Salnikov V.P. The Philosophy of Law and Legal Science. Newcastle upon Tyne: Cambridge Scholars Publishing, 2018. 270 p. DOI 10.17513 / np. 452.

99. Zakhartsev S.I., Maslennikov D.V., Salnikov V.P .: The Logos of Law: Parmenides - Hegel - Dostoevsky. The Speculative and Logical Foundations of the Metaphysics of Law. - London: Europe Books. 2021.450 p. DOI 10.17513 / np. 490.

For citation: Salnikov V.P., Komarov S.A., Kondrat I.N., Khabibulin A.G. Sergey Ivanovich Zakhartsev is 45 years old / / Theory of State and Law. 2021. No. 4 (25). P. 203-214.

DOI: $10.47905 /$ MATGIP.2021.25.4.022

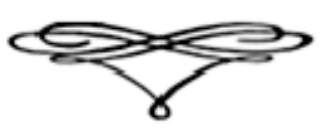




\section{ТРЕБОВАНИЯ \\ к оформиению рукописей, представмяемых дия опубинкования}

1. Рукопись представляется в одном экземпляре. Текст должен быть отпечатан через 1.5 компьютерных интервала 14 шрифтом. Страницы должны быть пронумерованы. Сноски оформляются в виде затекстовых ссылок в соответствии с библиографическими требованиями, размещаются после текста статьи под загомовком "Библиографический список". Источники в списке располагаются в соответствии с ГОСТ Р 7.0.5-2008 "Справки по оформцению списка митературы». При ссылке на конкретный фрагмент текста источника в отсылке указывается порядковый номер и страницы. Например:

- в тексте [8, с. 15].

- взатекстовой ссылке: Комаров С.А. Общая теория государства и права: учебник. - СПб.: Издательство Юридического института, 2012. - 520 с.

2. Объем статьи не должен превышать 8-10 машинописных страниц, а рецензии - 3 страниц.

3. Автор опмачивает расходы за редактирование, рецензирование и подготовку к публикации в размере ориентировочно 5600 руб., за превышение установценного объема - дополнительно 300 руб. за каждую страницу.

Отдельно оплачивается перевод статьи на английский язык.

Перевод рукописи статьи на ангмийский язык осуществляется редактором-переводчиком журнаха.

4. К статье домжны прилагаться:

- справка об авторах (соавторах) с указанием:

а) фамимии, имени, отчества;

б) ученой степени, ученого звания;

в) должности, основного места работы;

г) контактного e-mail, домашнего и служебного адресов и телефонов;

- аннотация статьи (не менее 5 строк);

- киючевые слова (не менее 10 слов);

- рецензия от научного руководителя (дАя студентов, магистрантов, аспирантов);

- справка о заимствованиях (антипмагиат)

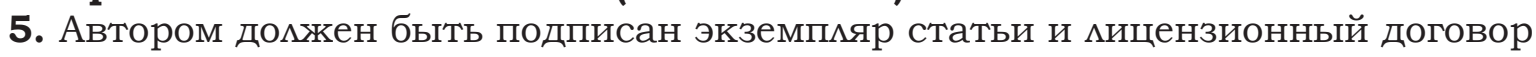
(высылается после утверждения "в печать" редакционной комлегией).

6. Пиата с аспирантов за пубцикацию не взимается (за искмючением стоимости 1 экземпмяра журнала, его пересымки адресату, перевода статьи на ангАийский язык).

7. Статьи, направленные авторам на доработку, подмежат возврату в редакцию в рекомендованный срок с производственными изменениями и исправлениями в тексте (в отпечатанном виде) и с эмектронной копией.

8. Рецензии присымаются вместе со статьями. В противном случае статьи опубликованы не будут.

9. Статьи направляются по почте (не заказной) на адрес редакции: 199106, Санкт-Петербург, В.О., УА. Гаванская, д. 3 и по эцектронной почте: lawinst-spb@mail.ru; komarova_tl@mail.ru

10. В случае несоблюдения настоящих требований по оформлению публикации редакция оставцяет за собой право ее не рассматривать. 


\section{REQUIREMENTS for Manuscripts, submitted for publication}

1. The manuscript is submitted in one copy. The text should be printed in 1.5 computer range 14 print. Pages must be numbered. Footnote out in the form of references in the endnotes according to bibliographic requirements are placed after the text of the article under the heading "References". Sources in the list are arranged in accordance with GOST R 7.0.5-2008 "Help on registration list of the literature». When referring to a specific piece of text is-sending source in the serial number and pages. For example:

- In the text [8, p. 15].

- In trans textual link: Komarov S.A. The general theory of state and law: the textbook. - St. Petersburg: Publishing House "Law Institute" (St. Petersburg), 2012. $608 \mathrm{pp}$.

2. The paper should not exceed 8-10 printed pages and reviews $\mathbf{- 3}$ pages.

3. The author pays for editing, review and preparation for the publication in the amount of 5600 rubles, for exceeding the specified amount - an additional 300 rubles for each page.

Translation of the article into English is paid separately.

Translation of the manuscript of the article into English is carried out by the editor-translator of the journal.

4. Article shall be accompanied (in electronic form):

- information about the author (co-author), indicating:

a) surname, name and patronymic;

b) scientific degree, academic rank;

c) the principal place of work, position;

d) an e-mail, home and office addresses and phone numbers;

- abstract of the article (not less than 5 lines)

- keywords (not less than 10 words)

- review

5. The author must be signed copy of the article and a license agreement (sent after the approval of "print" the editorial board). Articles graduate students must be signed by their research supervisor(s) to review the application.

6. The fee for the publication of a post-graduate students will be charged.

7. Articles, aimed authors for revision shall be returned to the editor in the recommendatory term production changes and corrections in the text (in the form of imprint) and an electronic copy.

8. Reviews are sent along with the article. Otherwise, the article will not be published.

9. Article sent by mail (not registered) to the editorial office: 199106, 3, Gavanskayast., Saint Petersburg, Russia and by e-mail: lawinst-spb@mail.ru; komarova_tl@mail.ru

10. In the case of non-compliance with these requirements by designing the publication editors reserve the right not to consider it. 


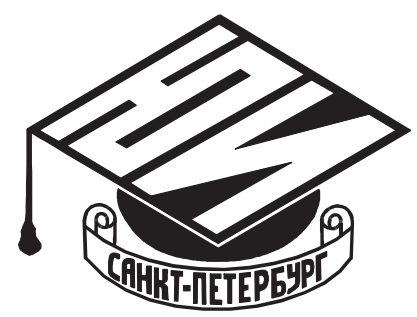

Частное образовательное учреждение высшего образования

\section{ЮРИДИЧЕСКИЙ ИНСТИТУТ (Санкт-Петербург) основан в 1992 году \\ Аицензия}

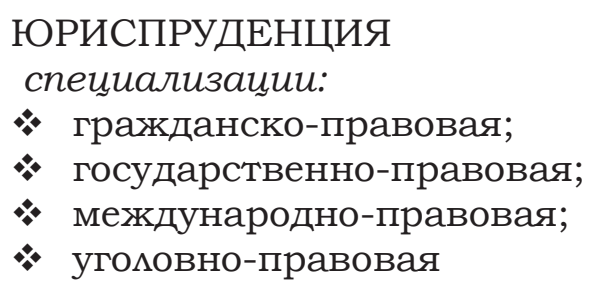

\section{Документы:}

1. Документ об образовании

2. Шесть фотографий размером $3 \times 4 \mathrm{~cm}$

3. Свидетельства ЕГЭ по русскому языку, обществознанию, истории России

По окончании института выпускникам присваивается степень бакалавра или магистра

(в зависимости от срока обучения)

и выдается диплом о высшем образовании

Срок обучения:

ДНЕВНОЕ - 4 года, ЗАОЧНОЕ - $5 \Lambda$ ЕТ

ДАя Аиц со средним юридическим и высшим образованием ускоренный курс обучения - 3 года

\section{Ведется прием в АСПИРАНТУРУ} по научным специацьностям:

12.00.01 - теория и история права и государства; история учений о праве и государстве

12.00.02 - конституционное право, конституционный судебный процесс; муниципальное право

12.00.08 - уголовное право и криминология; уголовно-исполнитецьное право

199106, г. Санкт-Петербург, уА. Гаванская, д. 3

(812) 325-46-25, 322-18-08

Официальный сайт: www.lawinst-spb.ru

Книжный интернет-магазин на сайте института 
Редактор, переводчик М.В. Старцева верстка И.И. Каширина

Адрес редакции: 199106, г. Санкт-Петербург, ум. Гаванская, д.3

E-mail: Legal_thought@mail.ru

Сайт: http:/ /lawinst-spb.ru/magazine http: / / matgip.ru

Темефон: (812) 325-4625; (499) 431-5806

Издатель: ЧОУ ВО “Юридический институт» (Санкт-Петербург) Адрес издателя: 199106, г. Санкт-Петербург, ул. Гаванская, д.3 Издатель: МОО «Межрегиональная ассоциация теоретиков государства и права"

Адрес издателя: 119415, Москва, Удамьцова 19-1-12

E-mail: matgip2017@yandex.ru

Выход в свет 18.12.2021. Формат 61х86 1/ .

Бумага офсетная. Печать цифровая.

Уч.-изд. ^. 26,42. Усл. п.м. 15,5. Тираж 100 экз. Заказ № 106245.

Цена свободная

Отпечатано в типографии "OneBook.ru"

ООО "Сам Полиграфист"

109316, г. Москва, Волгоградский проспект, дом 42, корп. 5, "Технополис Москва" www.onebook.ru 